\title{
Loopbaanadvisering een vak apart
}

Citation for published version (APA):

Tielenius Kruythoff, P. (2019). Loopbaanadvisering een vak apart: op weg naar een professie? [, Maastricht University]. Maastricht University. https://doi.org/10.26481/dis.20190329pk

Document status and date:

Published: 01/01/2019

DOI:

10.26481/dis.20190329pk

Document Version:

Publisher's PDF, also known as Version of record

\section{Please check the document version of this publication:}

- A submitted manuscript is the version of the article upon submission and before peer-review. There can be important differences between the submitted version and the official published version of record.

People interested in the research are advised to contact the author for the final version of the publication, or visit the DOI to the publisher's website.

- The final author version and the galley proof are versions of the publication after peer review.

- The final published version features the final layout of the paper including the volume, issue and page numbers.

Link to publication

\footnotetext{
General rights rights.

- You may freely distribute the URL identifying the publication in the public portal. please follow below link for the End User Agreement:

www.umlib.nl/taverne-license

Take down policy

If you believe that this document breaches copyright please contact us at:

repository@maastrichtuniversity.nl

providing details and we will investigate your claim.
}

Copyright and moral rights for the publications made accessible in the public portal are retained by the authors and/or other copyright owners and it is a condition of accessing publications that users recognise and abide by the legal requirements associated with these

- Users may download and print one copy of any publication from the public portal for the purpose of private study or research.

- You may not further distribute the material or use it for any profit-making activity or commercial gain

If the publication is distributed under the terms of Article $25 \mathrm{fa}$ of the Dutch Copyright Act, indicated by the "Taverne" license above, 


\section{Loopbaanadvisering een vak apart}

Op weg naar een professie?

Peter Tielenius Kruythoff 


\title{
LOOPBAANADVISERING EEN VAK APART: OP WEG NAAR EEN PROFESSIE?
}

\author{
PROEFSCHRIFT \\ ter verkrijging van de graad van doctor \\ aan de Universiteit Maastricht, \\ op gezag van de Rector Magnificus, \\ Prof dr. Rianne M. Letschert, \\ volgens het besluit van het College van Decanen, \\ in het openbaar te verdedigen op \\ vrijdag 29 maart 2019 om 12.00 uur \\ door \\ Peter Tielenius Kruythoff
}


Promotores:

Prof. dr. A. de Grip

Prof. dr. T.A.M.J. van Amelsvoort

\section{Copromotor:}

Dr. S. Schinkel (Sigma Research)

Beoordelingscommissie:

Prof. dr. W. Gijselaers (voorzitter)

Dr. J. Brassey (Universiteit Tilburg)

Prof. dr. G.J. Kok

Dr. J.R. König (Van Ede \& Partners) 


\section{DANKWOORD}

Dit proefschrift was nimmer tot stand gekomen zonder de vasthoudendheid van Therese van Amelsvoort, een goede vriendin van mijn dochter Frederika. Ik vertelde Therese in 2015 dat ik een proefschrift wilde schrijven over loopbaanadvisering, maar dat ik moeite had om een promotieplaats te bemachtigen. Prof. Dr. Therese van Amelsvoort, als hoogleraar Transitiepsychiatrie verbonden aan de Universiteit Maastricht, vroeg mij toen of zij een poging mocht doen om toch een plaats voor mij te bemachtigen. Therese merkte aanstonds dat haar collegae het maar een raar idee vonden om zich voor een man van boven de tachtig in te zetten. Therese zette door en belandde uiteindelijk bij de Rector Magnificus, die toestemming verleende. Zonder de volharding van Therese was dit proefschrift nimmer tot stand gekomen. Mijn dank aan Therese hiervoor is dan ook enorm!

Vervolgens hebben wij samen een hoogleraar aangezocht die mijn eerste promotor zou willen worden. Dat lukte bij de eerste poging. Therese stelde mij voor aan Prof. Dr. Andries de Grip. Het klikte meteen tussen ons. Sterker nog: Andries vond het als arbeidseconoom en HRM-specialist interessant om meer te vernemen over mijn vakgebied. Ik bleek de tweede promovendus te zijn die een proefschrift wilde schrijven over het jonge vakgebied. Natuurlijk wil ik Andries en Therese heel hartelijk danken voor de spontane gok die zij namen om met mij in zee te gaan en voor de bijzonder fijne begeleiding die zij mij als promotores hebben gegeven.

Therese en Andries raadden mij aan om als begeleider een methodoloog van de Universiteit Maastricht in de arm te nemen. Ik vond dat een goed idee, maar vond het bezwaarlijk om steeds naar Maastricht te moeten komen voor overleg. Annelies van Vianen, hoogleraar aan de UvA, raadde mij toen aan contact op te nemen met Dr. Sonja Schinkel. Ook met Sonja kreeg ik al in de eerste sessie bij mij op kantoor 
een klik. Ons contact was uiterst plezierig. Zonder haar grote zorgvuldigheid was het mij stellig niet gelukt om mijn proefschrift binnen drie jaar af te ronden. Ik kan iedereen na mij aanraden om met Sonja contact op te nemen als je werkelijk van zins bent om een proefschrift te schrijven. Een goed klankbord is dan immers buitengewoon plezierig. Sonja, bijzonder veel dank voor onze geweldige samenwerking en fijn dat je dit werk kon doen als copromotor.

Naast Andries en Therese wil ik natuurlijk ook de beoordelingscommissie van harte danken voor de aandacht die zij aan mijn proefschrift hebben besteed. Dat zijn Prof. Dr. Wim Gijselaers als voorzitter en Prof. Dr. Gerjo Kok, Dr. Jutta König en Dr. Jacqueline Brassey als leden van de commissie. Ook gaat mijn dank uit naar de overige leden van de corona. Dat zijn Prof. Dr. Annelies van Vianen, Prof. Dr. Karen van Dam en Dr. Ben Emans.

Ook hebben zeer veel van mijn vroegere collegae als vrijwilliger meegewerkt aan het proefschrift. Aan de enquête inzake de effecten van de begeleiding hebben 161 collega-loopbaanadviseurs meegewerkt. Er waren 128 cliënten en 96 opdrachtgevers van deze groep collegae die een enquête hebben ingevuld. Zodoende kon ik betrouwbare resultaten laten zien. Van die 161 collegae wil ik er graag een aantal met name noemen, die zich extra ingespannen hebben om meerdere cliënten en meerdere opdrachtgevers te stimuleren om mee te doen aan de hen toegestuurde enquêtes. Dit waren: Charlotte Baan, Sjanie Brussee, Hans Fibbe, Ria Freijsen, Caroline Harder, Friederike Korte, Wenneke Ong, Ciska Pittie, Pierre Remijn, Els Verheijen, Anton de Vries, Eva de Waard, Ieke Witteveen en Gonny Zwartjes. Daarnaast hebben zes collegae zich bereid verklaard om als expert mee te doen aan de beoordeling van de casusvoorbeelden over het ethische dilemma. Dat waren Els Ackerman, Maarten ter Braak, Paul van Egmond, Herman Lamers, Rob Stolk en Jannie van Zuylen. 
Er waren ook zes collegae die mij geholpen hebben door de casusvoorbeelden van de arbeidsmarktbegeleiding te beoordelen. Dat waren Peter Aalders, Peter Elffers, Annelies Le Fèvre, Friederike Korte, Hans Leewens en Jan Schuitemaker. Voor de beoordeling van de specifieke competenties had ik naast collegae ook vertegenwoordigers van aanpalende bedrijfstakken gevraagd, zoals Han Kemker als arbeidsdeskundige, mijn dochter Frederika Tielenius Kruythoff als expert op het gebied van executive search en loopbaanbegeleiding en Ton van Voorden als psycholoog. Daarnaast werkten vele van mijn oud-collegae en collegamentoren bij CMI aan dit hoofdstuk mee, zijnde: Roxane Beumer, Ricky Boom, Helene van Boxmeer, Annet Brinkhuis, Sjanie Brussee, Ria Freijsen, Meys Gimbrère, Caroline Harder, Willem de Jong, Jutta König, Vérène Laane, Peter Minkenberg, Ciska Pittie, Jolanda Schouten, Kees de Vries, Ieke Witteveen en Willem Ijzereef.

Als acht vertegenwoordigers van een beroep dat in de volksmond een professie genoemd wordt, hebben Mark van Bijsterveld (apothekers), Michiel Eijkman (tandheelkunde), Hans van Es (advocatuur), Beate van der Heijden (wetenschap), Edzo Huisman (notariaat), Abel Koomen (geneeskunde), Peter Krom (accountants), en Matias Smalbrugge (geestelijkheid) meegedaan aan een enquête, die criteria omvatte inzake een professie.

Als ik goed geteld heb dank ik in dit dankwoord 54 collegae voor hun aandeel in dit proefschrift. Ik schaam mij enigszins dat ik zovelen van mijn collegae heb durven uitnodigen om mij met hun expertise bij te staan. De meesten hebben hun oordeel als expert inzake loopbaanadvisering gegeven. Zonder hen was het voor dit proefschrift vereiste veldwerk niet tot stand gekomen.

Ook gaat mijn dank uit naar de bestuursleden van Career Management Institute (CMI). Zonder jullie toestemming om de casusvoorbeelden uit de periode 2012 - 2014 anoniem te gebruiken, was dit proefschrift nimmer tot stand gekomen. 
Ik ben jullie zeer erkentelijk voor deze toestemming en hoop dat ook besturen na jullie nieuwe promovendi toestemming zullen willen geven om het onderzoek voort te zetten. Ik heb meer dan twintig suggesties gedaan voor vervolgonderzoek.

Veel dank ook aan de loopbaanadviseurs die op mijn verzoek toestemming gegeven hebben om hun casusvoorbeeld in mijn proefschrift te kunnen gebruiken met naam en toenaam. Dat waren: Lies Pol over het ethische dilemma; Channah van Dootingh over artikel 6 van de CMI-gedragscode; Nicole Noyons over inlevingsvermogen in het kader van de specifieke competenties; en Ingrid Koster over arbeidsmarktbegeleiding. Er was ook een cliënt, die beschreef hoe sceptisch zij in eerste instantie was over het te volgen traject, maar hoe zij met behulp van haar loopbaanbegeleider enthousiast werd over de toekomst en naar eigen zeggen "weer straalde". De cliënt en haar begeleider wensten echter anoniem te blijven. De casus op pagina 184 spreekt echter voor zich.

Binnen mijn inner circle wil ik allereerst mijn goede vriend Michiel Eijkman en mijn zwager Flip van Lidth de Jeude noemen. Beiden hebben mij in eerste instantie getracht enige beginselen bij te brengen van het schrijven van een proefschrift. Michiel heeft mij ook de suggestie gedaan om de effecten van de begeleiding als hoofdstuk toe te voegen. Dat werd mijns inziens het meest interessante hoofdstuk van het proefschrift. Ook Johannes Katsarov, die mij hielp aan een goede ontwikkeltheorie voor het onderzoek inzake het ethisch dilemma, maar ook Niels Schillewaert, voor zijn suggestie inzake 'the Grounded Theory' ten behoeve van het onderzoek naar de arbeidsmarktbegeleiding, en Ton Rijers, die ik via Addy Pols ontmoette, voor zijn aandeel over het UWV, alsmede Elsje Rempt voor haar aandeel in de vertaling van de samenvatting, wil ik alle zes heel hartelijk danken voor hun zeer gewaardeerde aandeel in het proefschrift. 
Dan kom ik toe aan mijn paranimfen. Allereerst Annelies Le Fèvre: wij werken nu 21 jaar samen. Iedere dag was het fijn om naar kantoor te gaan en met zijn tweeën te werken aan de uitbouw van loopbaanadvisering als vakgebied. Eerst door NOBOL op de kaart te zetten en vervolgens CMI. Samen werkten wij twee en een half jaar om CMI door de Raad van Accreditatie ISO geaccrediteerd te krijgen. Het was een enorme krachtsinspanning, maar zeer de moeite waard om goede kwaliteit voor het vakgebied door certificering te kunnen garanderen. Annelies gaf mij ook het advies mijn idee, om aan het einde van mijn werkzame leven een proefschrift over loopbaanadvisering te schrijven, door te zetten. Zonder haar enthousiasme was ik er waarschijnlijk nooit aan begonnen. Als kunstschilder heeft Annelies ook de kaft van mijn proefschrift gemaakt. Het stelt het (Noorder)licht in de duisternis voor, dat symbool staat voor de betekenis die loopbaanadvisering heeft voor velen.

Vervolgens Maarten ter Braak, die mij in vele zaken, zoals het voorzitterschap van NOBOL, opvolgde, maar voor certificering in eerste instantie niet veel voelde. Pas toen hij begreep dat het ging om de kwaliteit van het vakgebied, dat door certificering zeer verbeterd kon worden, volgde hij mij ook op als zeer bijzondere mentor van CMI. Zijn aandacht voor mijn proefschrift en zijn waardevolle suggesties hebben mij geholpen om het proefschrift toch nog in drie jaar voor elkaar te krijgen.

De inner circle wordt besloten door mijn liefhebbende familie. Het is jammer dat mijn vader en moeder niet meer leven. Speciaal mijn vader had het heel bijzonder gevonden om zijn zoon te zien promoveren. Toen ik mijn doctoraal behaalde stelde hij voor om middelen beschikbaar te stellen om te promoveren. Hij had ook al een onderwerp bedacht, namelijk 'de Hanzesteden van Europa'. Ik wilde toen aan het werk in het bedrijfsleven, maar zijn suggestie is mij bijgebleven. 
Ik weet ook hoe mijn kinderen enthousiast waren en bleven toen ik hen vertelde dat ik van plan was een dissertatie te schrijven over mijn vakgebied. Kees vraagt mij iedere keer hoe het met mijn promotie gaat als ik hem spreek. Vooral in de laatste maanden had hij wel wat anders aan zijn hoofd. Ook Frederika wilde steeds op de hoogte zijn. Het was ook bijzonder dat ik via haar met Therese contact kreeg, waardoor mijn plan toch gelukt is. Het was natuurlijk ook bijzonder dat zij, als expert in executive search, meegedaan heeft aan de beoordeling van de specifieke competenties. Dat mijn zeven kleinkinderen nu allemaal groot genoeg zijn om de verdediging van mijn proefschrift mee te maken, is extra bijzonder. Welke promovendus maakt dat mee!

En ten slotte de 'dissertatie weduwe', zoals Michiel Eijkman Martine noemt. Promoveren is nu eenmaal een eenzame aangelegenheid. Dat was het ook voor Martine. Zij heeft mij erg geholpen met de correcties van het proefschrift, waarvoor heel veel dank. Ik meen dat zij het ook wel erg leuk vond dat ik dit plan heb doorgezet. $\mathrm{Zij}$ komt tenslotte ook uit een familie waar promoveren een goede gewoonte is. Ten slotte hoop ik dat mijn collegae en vooral ook de nieuwe generatie, die ongetwijfeld loopbaanadvisering als wo-studie normaal zullen gaan vinden, mijn proefschrift lezenswaardig zullen vinden en vooral mijn aanbevelingen voor vervolgstudie zullen opvolgen. Dan is dit proefschrift de moeite waard!

TK; Oktober 2018 
DANKWOORD 3

\section{HOOFDSTUK 1}

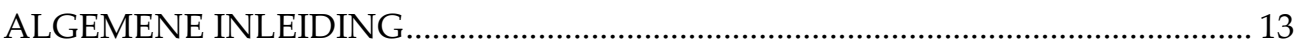

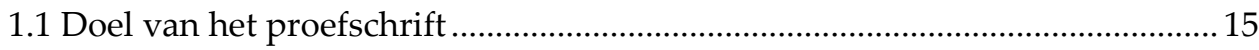

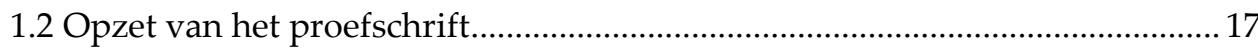

\section{HOOFDSTUK 2}

EEN SCHETS VAN DE PRIVATE ONTWIKKELING VAN DE

LOOPBAANADVISERING IN NEDERLAND 1978 - 2018 ....................................... 23

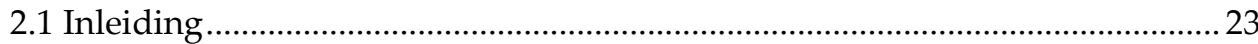

2.2 Historische schets van de ontwikkeling van de loopbaanbemiddeling door de overheid in de periode 1978 - 2018 ..................................................................... 26 2.3 Korte historie van de ontwikkeling van loopbaanadvisering in de private

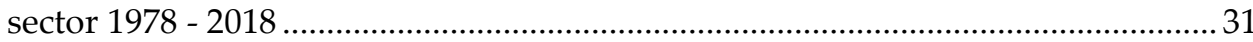

2.4 Maatschappelijke aandacht voor Keurmerken en Certificering ..................... 42 HOOFDSTUK 3

DE ONTWIKKELING NAAR EEN PROFESSIE .................................................. 47

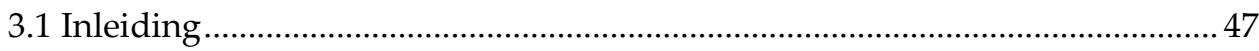

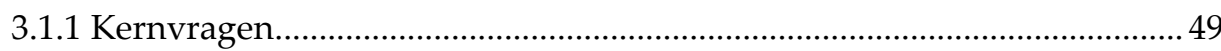

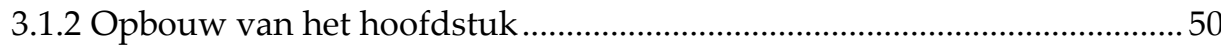

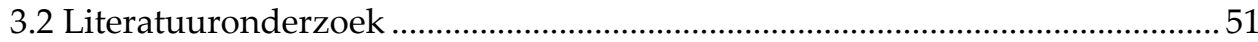

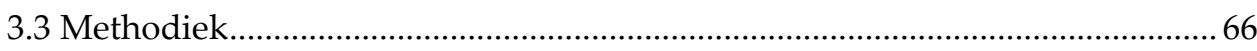

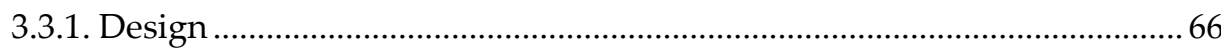

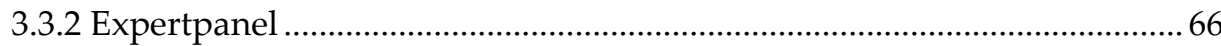

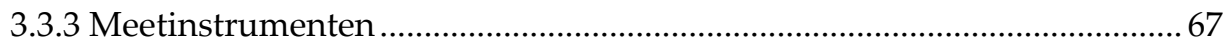

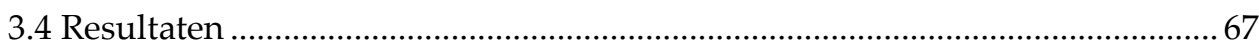

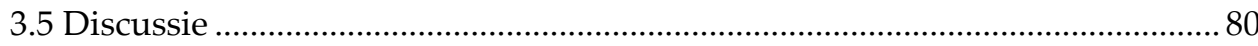



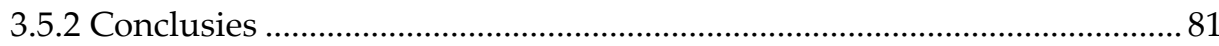




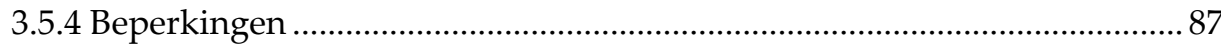

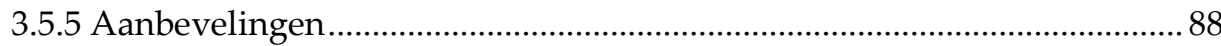

\section{HOOFDSTUK 4}

ETHIEK ALS BASIS VOOR HET HANDELEN_VAN LOOPBAANADVISEURS... 91

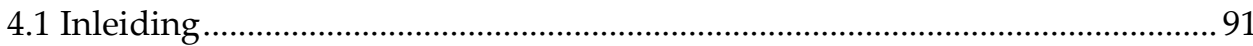

4.2 Methodiek van onderzoek naar ethisch handelen van loopbaanadviseurs ... 95

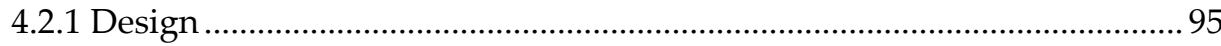

4.2.2 Steekproef.................................................................................................... 105

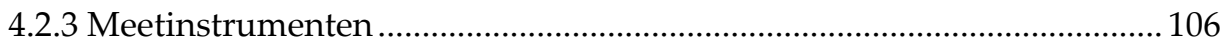

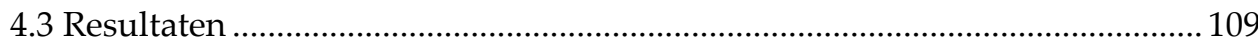

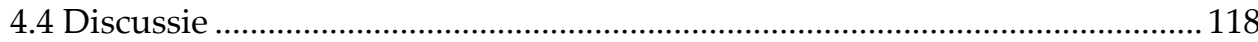

4.4.1 Bevindingen van het onderzoek .......................................................... 118

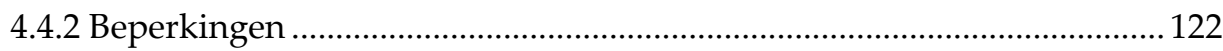

4.4.3 Aanbevelingen ......................................................................................... 124

HOOFDSTUK 5

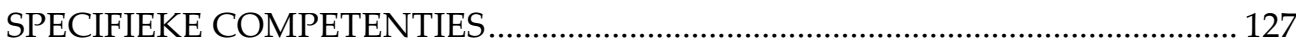

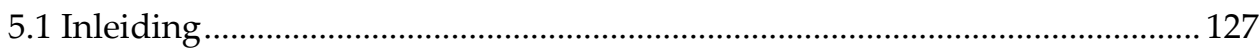

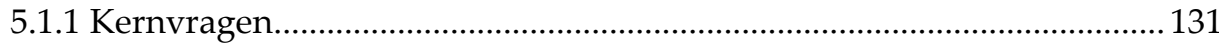

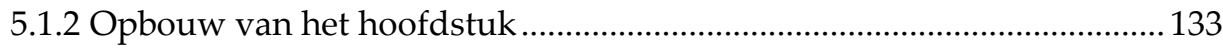

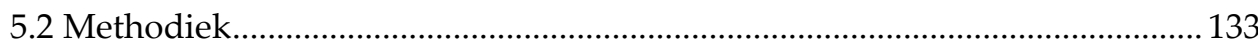

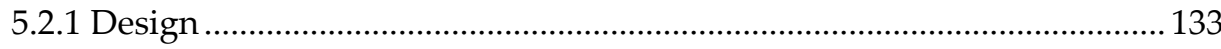

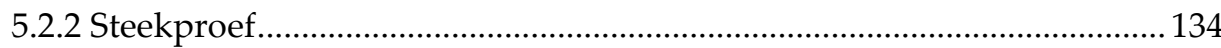

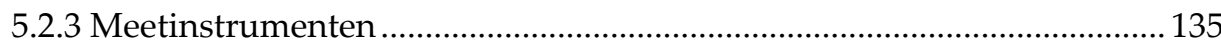

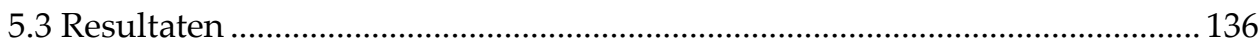

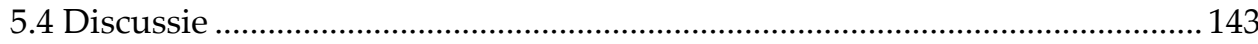

5.4.1 Bevindingen van het onderzoek ............................................................... 143

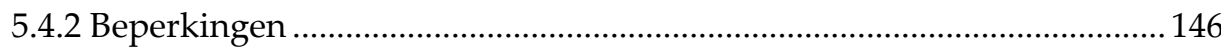




\section{HOOFDSTUK 6}

ARBEIDSMARKTBEGELEIDING

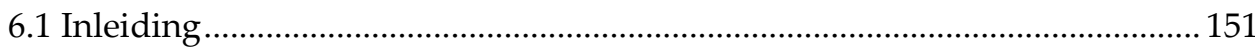

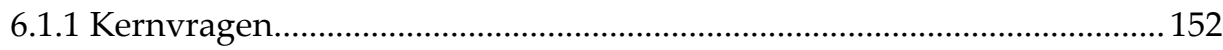

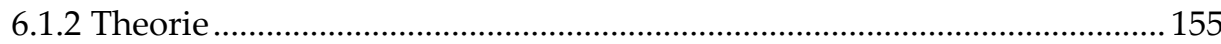

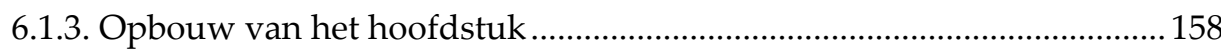



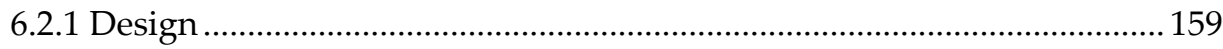

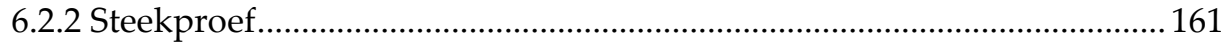



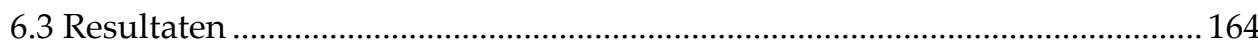

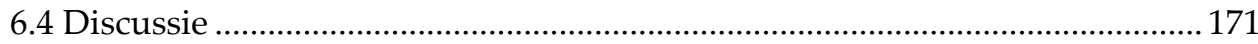

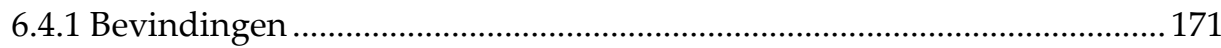

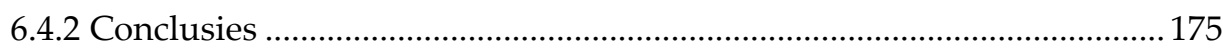

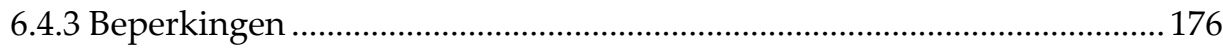

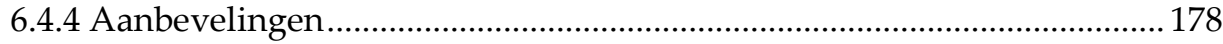

\section{HOOFDSTUK 7}

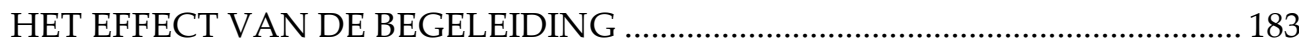

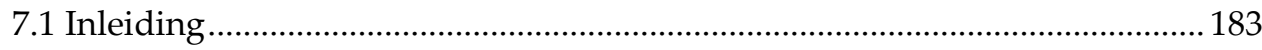

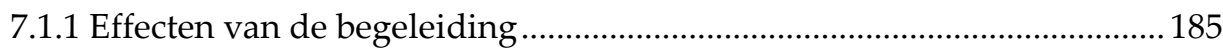

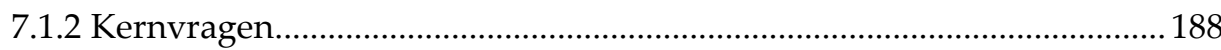

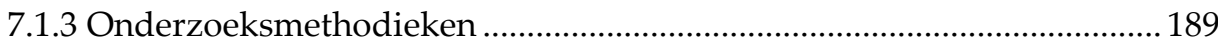

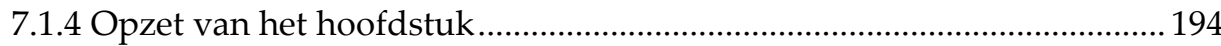

7.2 Methode

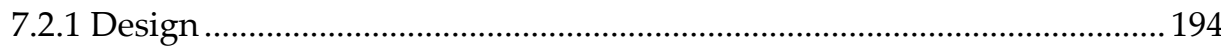

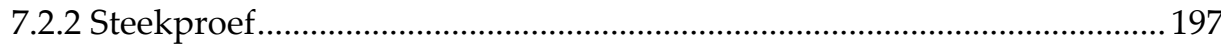

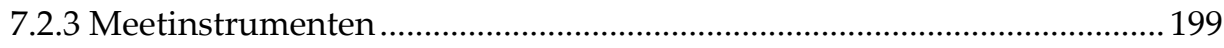




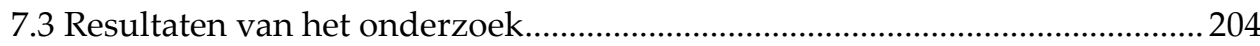

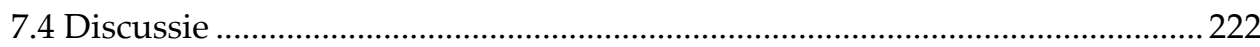

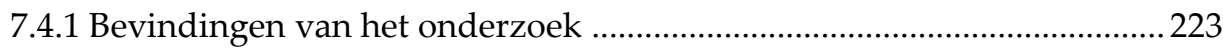

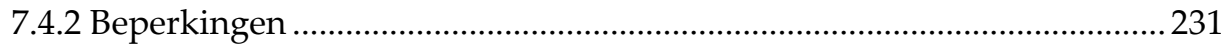

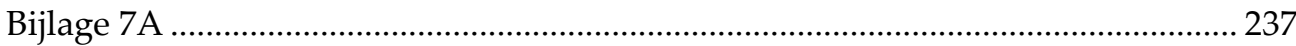

\section{HOOFDSTUK 8}

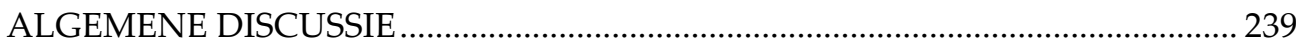

Samenvatting van de belangrijkste bevindingen ................................................... 240

Loopbaanadvisering op weg naar een professie? ............................................... 247

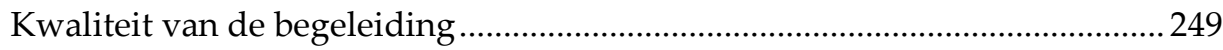

Verschillen tussen de drie CMI-niveaus .............................................................. 250

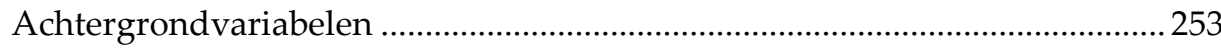

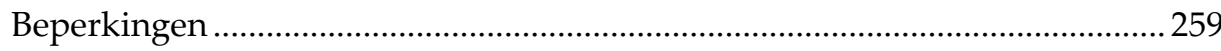

Aanbevelingen uit de vier onderzoekhoofdstukken van dit proefschrift......261

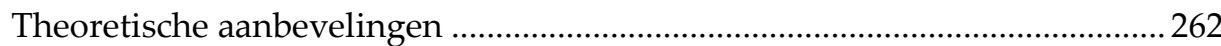

Aanbevelingen voor de praktijk ........................................................................ 266

ADDENDUM:

DE WAARDE VAN HET PROEFSCHRIFT VOOR DE MAATSCHAPPIJ .............. 273

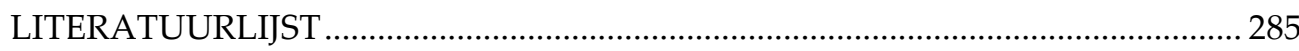

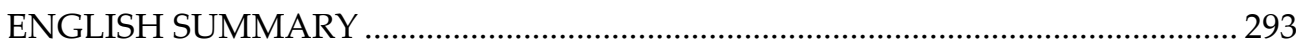

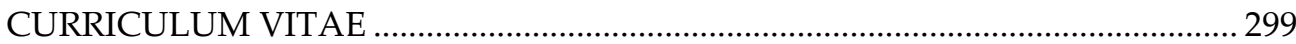




\section{HOOFDSTUK 1}

\section{ALGEMENE INLEIDING}

Na het voorzitterschap van de Stichting 'Career Management Intstitute Netherlands' (CMI), dé certificerende instelling voor persoonscertificering op het gebied van loopbaanadvisering in Nederland, in het voorjaar 2016 te hebben neergelegd, lag het voor de hand om alle kennis en ervaring die de auteur van dit proefschrift opgedaan had vast te leggen. Hij had immers vanaf het begin de ontwikkeling van 'loopbaanadvisering', de nieuwe beroepsgroep in de private sector voor loopbaanbegeleiding en -coaching, meegemaakt. Bovendien beschikte CMI over een groot aantal dossiers en casusvoorbeelden, die uitstekend gebruikt konden worden voor onderzoek naar de vraag in hoeverre loopbaanadvisering zich in circa veertig jaar ontwikkeld heeft naar een professie.

In 2007 werd door het bestuur van de Stichting 'Career Management Intstitute Netherlands' besloten om te onderzoeken of ISO 17024, ontworpen voor persoonscertificering, een efficiënte vorm zou kunnen zijn voor het toetsen van de vakbekwaamheid van loopbaanadviseurs. Naar aanleiding van het onderzoek om aan de eisen van de Raad voor Accreditatie te kunnen voldoen, moest er veel veranderen aan het bestaande concept van CMI. De basis voor certificering kon echter blijven bestaan. Dit was de toetsing van loopbaanadvieskandidaten voor certificering naar aanleiding van een van tevoren voorbereid dossier dat door een toetsingscommissie getoetst werd. Om te voldoen aan ISO 17024 moesten echter drie zaken aan het bestaande concept toegevoegd worden: 1) er moest normatief getoetst worden, dus naar aanleiding van tevoren vastgestelde normen; 2) de toetsing van de vakbekwaamheid moest onafhankelijk geschieden; 3) CMI als certificerende 
instelling moest jaarlijks zelf onderworpen worden aan een onafhankelijk onderzoek door de Raad voor Accreditatie.

Het voornemen om te werken met normen van ISO 17024 werd najaar 2007 door het CMI-bestuur gehonoreerd, maar het duurde tot 2010 voordat CMI het certificaat van de Raad voor Accreditatie in ontvangst kon nemen, waardoor de te certificeren loopbaanadviseurs onder accreditatie volgens ISO/IER17024//2004 (thans 2012) door CMI gecertificeerd konden worden.

Bij CMI is de procedure voor certificering als volgt. De certificering van loopbaanadviseurs focust op de begeleiding van de cliënt. Om volgens ISO te toetsen wordt vooraf gevraagd om voorbeelden van de verschillende loopbaanthema's in lijn te brengen met vooraf opgestelde normvoorbeelden van het beroepsprofiel. De loopbaanadviseur wordt verondersteld het samenstel van taken, kennissectoren en specifieke competenties (tezamen het beroepsprofiel) te beheersen om zich vakbekwaam te kunnen noemen. Dit wordt vastgesteld door de kennissectoren, de taken van de adviseur en de specifieke competenties in het kader van ISO 17024 te toetsen aan de normvoorbeelden zoals deze in het beroepsprofiel en de verbijzondering van het beroepsprofiel zijn vastgelegd. Op deze wijze kan (bij benadering) gemeten worden of een kandidaat voor certificering voldoet aan de door CMI gestelde normatieve eisen.

De meetbaarheid van adviserende dienstverlening is een nieuw fenomeen. Plant (2004) constateert hoe moeilijk het is om de kwaliteit van dienstverlening (en zeker van advisering) te meten, omdat deze kwaliteit te subjectief is om goed meetbaar te zijn. In het kader van het kwaliteitsmanagementsysteem ISO 17024 is het echter mogelijk om deze kwaliteit te meten door bij de certificering te vragen om voorbeelden van de verschillende loopbaanthema's te geven en de kwaliteit daarvan te toetsen door deze te vergelijken met tevoren vastgestelde normvoorbeelden. 
Wereldwijd is ISO 17024 zeer bekend, maar nog maar tweemaal eerder werd ISO 17024 gebruikt als het gaat om adviserende dienstverlening. Beide keren overigens in Nederland.

Omdat het hier gaat om een relatief nieuwe beroepsgroep en een nieuwe methodiek in de dienstverlenende sfeer, is het van groot belang om te onderzoeken hoe effectief deze methode is voor het meten van de kwaliteit van loopbaanadviesdiensten. Toen de auteur van dit proefschrift besefte dat hij vanaf het prille begin intensief bij deze ontwikkeling betrokken was geweest, vond hij het ook voor de hand liggen om verder onderzoek te doen door een dissertatie over dit onderwerp te schrijven. Alle vijf onderzoekhoofdstukken van het proefschrift zijn gewijd aan de kwaliteit van loopbaanadvisering. Door het meten van de kwaliteit van de loopbaanadvisering is het bovendien mogelijk om de vraag te beantwoorden of dit vakgebied zich heeft ontwikkeld tot een professie.

\subsection{Doel van het proefschrift}

Het doel van dit proefschrift is om de kwaliteit van de loopbaanadvisering te onderzoeken. Het onderzoek richt zich daarbij met name op de vraag in hoeverre de loopbaanadvisering ${ }^{1}$ in Nederland zich in circa veertig jaar heeft ontwikkeld tot een professie. Daarbij wordt er naast de vraag wat de wetenschap verstaat onder een professie, achtereenvolgens gekeken naar een viertal belangrijke kenmerken van loopbaanadvisering, namelijk: 1) ethiek, en dan met name het ethische dilemma in het kader van de drie deelnemende partijen: de adviseur, de cliënt en de opdracht-

\footnotetext{
${ }^{1}$ Loopbaanadvisering heeft zich op commerciële basis in Nederland pas ontwikkeld sinds 1978. In de Verenigde staten en Engeland is de ontwikkeling eerder van start gegaan. In de VS werd sinds de terugkomst van de militairen uit Korea in de jaren vijftig van de vorige eeuw 'outplacement' ingezet, als onderdeel van wat men tegenwoordig loopbaanadvisering noemt. In Engeland werd in de jaren zestig van de vorige eeuw eveneens gestart met 'outplacement'.
} 
gever; 2) specifieke competenties van de loopbaanadviseur; 3) kwaliteit van arbeidsmarktbegeleiding en 4) effecten van de begeleiding voor de cliënt.

Loopbaanadvisering wordt in dit proefschrift gekoppeld aan wat CMI hieronder verstaat (zie Figuur 1.1). De scope van CMI-loopbaanadvisering geeft definities voor vier onderdelen van loopbaanadvisering, te weten: 1) loopbaanbegeleiding, 2) loopbaancoaching, 3) outplacement en 4) re-integratie tweede spoor. Outplacement en re-integratie tweede spoor zijn specifieke onderdelen van loopbaanbegeleiding, maar omdat deze twee varianten zo frequent voorkomen heeft CMI deze onderdelen specifiek benoemd. Loopbaanbegeleiding in de organisatie wordt door CMI niet specifiek benoemd. In analogie met CMI worden in dit proefschrift onder loopbaanadvisering vier taakgebieden (scopes) verstaan aan de hand van de volgende definities: ${ }^{2}$

Loopbaanbegeleiding: "Onder loopbaanbegeleiding wordt het dynamische begeleidingsproces van een persoon of een groep van personen verstaan die door analyse en verdere begeleiding van een loopbaanprofessional keuzes maakt (of maken) ten aanzien van het verdere verloop van zijn (hun) loopbaan voor heden en toekomst."

Loopbaan coaching: "Onder loopbaan coaching wordt het begeleidingsproces van een persoon of een groep van personen verstaan die, op de werkplek, analyse en verdere begeleiding van een loopbaanprofessional ontvangt, waardoor het efficiënt en effectief handelen van de persoon of van de groep van personen verhoogd wordt."

Outplacement: "Onder outplacement wordt het geheel van diensten en faciliteiten verstaan dat door een loopbaanprofessional beschikbaar gesteld wordt aan werkgevers, ten behoeve van werknemers. Het heeft tot doel de werknemer te

\footnotetext{
${ }^{2}$ Zie CMI-website www.cminl.nl.
} 
begeleiden bij het vinden van een nieuwe passende werkkring of andere bestemming."

Re-integratie tweede spoor: "Onder re-integratie buiten de organisatie verstaat CMI het proces dat een persoon of een groep personen doorloopt om weer deel te nemen aan het arbeidsproces. Dat vindt plaats vanuit een niet-werkende positie: bij ziekte, werkloosheid of ontslag. De loopbaanprofessional zet hierbij voor reintegratie specifieke kennis in en werkt samen met de opdrachtgever en andere deskundigen."

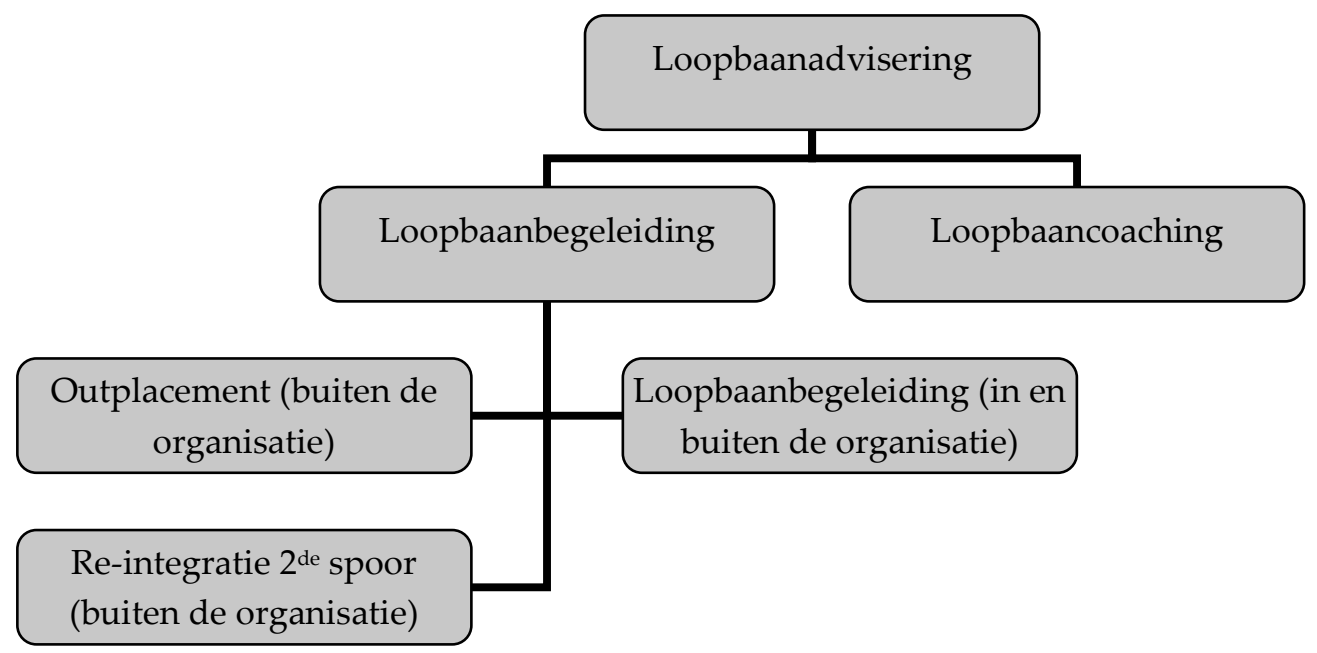

Figuur 1.1. Scope loopbaanadvisering.

\subsection{Opzet van het proefschrift}

Het proefschrift is opgebouwd uit acht hoofdstukken, waaronder een historisch overzicht van loopbaanadvisering en vijf onderzoekhoofdstukken. De acht hoofdstukken betreffen:

Hoofdstuk 1: Inleiding. In dit hoofdstuk zal de relatie worden gelegd tussen de opbouw van het proefschrift en de werkwijze van CMI als certificerende instelling. 
Ook zal kort worden aangegeven dat het voor het vakgebied van de loopbaanadvisering van groot belang is om in kaart te brengen hoe effectief het kwaliteitszorgsysteem (ISO 17024) is en in hoeverre het vakgebied zich reeds heeft ontwikkeld tot een professie. Vervolgens wordt duidelijk gemaakt uit welke onderdelen loopbaanadvisering bestaat en welke onderwerpen er in de verschillende hoofdstukken zullen worden onderzocht.

Hoofdstuk 2: De schets van loopbaanadvisering in Nederland. In dit hoofdstuk zal een schets worden gegeven van loopbaanadvisering in de eerste veertig jaar van de geprivatiseerde uitoefening van het vak in Nederland. Doordat er in de wetenschappelijke literatuur, zeker wat Nederland betreft, weinig bekend is van de ontwikkeling van loopbaanadvisering in de private sector, focust het proefschrift juist hierop, om te laten zien welke bijdrage de private sector geleverd heeft om de loopbaanadvisering te professionaliseren.

Hoofdstuk 3: In welke mate heeft loopbaanadvisering zich ontwikkeld tot een professie? In dit hoofdstuk zal allereerst in de wetenschappelijke literatuur over professies gezocht worden naar een passende definitie. Het blijkt dat een definitie moeilijk te geven is, maar dat criteria voor een professie de beroepsgroepen goed kunnen afdekken. Om dit te illustreren werd, in het kader van het onderzoek, een vragenlijst opgesteld, die werd voorgelegd aan acht representanten van acht beroepsgroepen die alle acht bekend staan als een 'professie', alsook aan representanten van de loopbaanadvisering. Door de resultaten met betrekking tot de loopbaanadvisering te vergelijken met die van de andere professies kan - zij het met grote voorzichtigheid - een eerste indruk worden gegeven van de mate waarin loopbaanadvisering zich heeft ontwikkeld tot een professie.

Hoofdstuk 4: Ethiek: In hoeverre heeft loopbaanadvisering zich in ethisch opzicht ontwikkeld in de richting van een professie? In dit hoofdstuk zal worden onderzocht hoe 
casusvoorbeelden over ethiek van de door CMI te certificeren loopbaanadviseurs passen in vijf ethische ontwikkelingsniveaus, in analogie met Kohlberg (1958). Op deze manier wordt de mate van de ethische ontwikkeling per CMI-niveau van de kandidaten in het kader van de certificering onderzocht. Gezien het belang van ethiek voor het vakgebied en de beperkte literatuur over ethiek in het kader van loopbaanadvisering, is het onderzoek belangrijk voor de mate waarin het vakgebied zich ontwikkelt tot een professie.

Hoofdstuk 5: Specifieke Competenties. In dit hoofdstuk zal onderzoek worden gedaan naar de toepassing van vijf specifieke competenties door loopbaanadviseurs, te weten: 1) inlevingsvermogen; 2) effectief communiceren; 3) reflecteren; 4) adviseren; 5) coachen. Hiertoe werden casusvoorbeelden uit dossiers van honderd kandidaten voor certificering op deze vijf competenties beoordeeld. Hiermee wordt inzicht verkregen in de mate waarin de gebruikte competenties in het begeleidingsproces bijdragen aan de ontwikkeling van de beroepsgroep tot een professie.

Hoofdstuk 6: Arbeidsmarktbegeleiding. In dit hoofdstuk zal worden onderzocht in hoeverre loopbaanadvisering zich heeft ontwikkeld als het gaat om de begeleiding naar de arbeidsmarkt. Om door CMI gecertificeerd te worden heeft de loopbaanadviseur een breed overzicht nodig van de arbeidsmarkt en van de arbeidsmarktontwikkelingen. Op basis van de Grounded Theory (GT) zijn 150 casusvoorbeelden in negen centrale thema's ondergebracht. Deze werden vervolgens door een aantal loopbaanexperts beoordeeld op kwaliteit. Deze beoordeling geeft een indicatie van de mate waarin de kennis van de arbeidsmarkt aanwezig is en bijdraagt aan de professionalisering van de loopbaanadvisering.

Hoofdstuk 7: Effecten van de begeleiding. In dit hoofdstuk zal worden onderzocht of er daadwerkelijk effecten zijn van loopbaanadvisering. Dit onderzoek is gebaseerd op een vragenlijst die is uitgezet onder circa 300 loopbaanprofessionals 
die door CMI gecertificeerd werden. Aan hen en ook aan hun cliënten en opdrachtgevers werd een vragenlijst voorgelegd, waarbij gevraagd werd in hoeverre de begeleiding effect heeft gehad voor de cliënt. Daarbij werden drie variabelen gemeten, namelijk: 1) de tevredenheid met de begeleiding van zowel de cliënt als de opdrachtgever; 2) de baantevredenheid van de cliënt en 3) in hoeverre vijf ontwikkelaspecten, namelijk: zelfbeeld, relatie met de werkomgeving, functioneren, communicatieve vaardigheden en zelfsturend vermogen, in de ogen van de loopbaanadviseur, de cliënt en de opdrachtgever verbeterd waren door de begeleiding. Uit de resultaten blijkt hoe sterk de effecten van de begeleiding zijn, zowel op de korte als op de middellange termijn.

Hoofdstuk 8: Discussie, conclusies en toekomstige ontwikkelingen. In dit hoofdstuk komen de conclusies en aanbevelingen uit alle hoofdstukken aan de orde, eerst afzonderlijk en daarna in relatie tot elkaar. Daarbij wordt aangegeven hoe deze conclusies en aanbevelingen kunnen helpen in de toekomstige ontwikkeling van het vakgebied tot een professie.

\section{Toelichting beoordelingsgrondslag}

Als beoordelingsgrondslag zijn door de auteur van dit proefschrift vier maatstaven voor kwaliteit gebruikt, te weten: onvoldoende, voldoende, goed en uitmuntend. Voor de berekening van kwaliteit volgens de Net Promotor Score (NPS) wordt voor de kwaliteitsmaatstaven slechts voldoende en uitmuntend gebruikt. Deze beoordelingsgrondslagen worden op vier manieren uitgedrukt:

1) Van 1 tot 5 op de (Likert-)vijfpuntsschaal: in alle vier onderzoekshoofdstukken wordt de vijfpuntsschaal gebruikt, alsmede ook in Hoofdstuk 3 inzake de professie. Alle beoordelingen $<3$ worden met onvoldoende aangemerkt; alle 
beoordelingen tussen 3 en 4 met voldoende; alle beoordelingen tussen 4 en 5 met goed en alle beoordelingen gelijk aan 5 met uitmuntend.

2) Van 1 tot 10 op een tienpuntsschaal: deze wordt gebruikt voor de beoordeling van de zogenaamde verklaringen van de cliënt en de opdrachtgever in Hoofdstuk 7. De beoordelingen $<6$ worden als onvoldoende aangemerkt; de beoordelingen tussen 6 en 8 als voldoende en de beoordelingen tussen 8 en 10 als goed. Beoordelingen gelijk aan 10 worden aangemerkt als uitmuntend.

3) In Hoofdstuk 7 wordt tevens gewerkt met NPS. Deze methode van berekenen wordt eveneens op een tienpuntsschaal gemeten. Alle beoordelingen $\geq 9$ worden van de beoordelingen tussen 0 en 7 afgetrokken; alle beoordelingen tussen 7 en 8 zijn neutraal en worden niet meegeteld. Het opgetelde resultaat van de beoordelingen tussen 9 en 10, minus het opgetelde resultaat van de beoordelingen tussen 0 en 7 , dient $<50$ te zijn om als goed te kwalificeren en $\geq 50$ om te kwalificeren als uitmuntend.

4) In diverse hoofdstukken wordt naast met de Likert-schaal de kwaliteit ook in percentages uitgedrukt en wel als volgt: onvoldoende $<60 \%$; voldoende $\geq 60 \%$; goed $\geq 80 \%$ en uitmuntend $\geq 90 \%$. 



\section{HOOFDSTUK 2 \\ EEN SCHETS VAN DE ONTWIKKELING VAN LOOPBAANADVISERING IN NEDERLAND 1978 - 2018}

In dit hoofdstuk wordt een schets gegeven van de inspanningen en resultaten van circa veertig jaar particulier initiatief op het gebied van loopbaanadvisering in Nederland. Na de inleiding (paragraaf 2.1) geeft paragraaf 2.2 een historische schets van de ontwikkeling van loopbaanbemiddeling door de overheid in de periode 1978 -2018. Vervolgens beschrijft paragraaf 2.3 de ontwikkeling van loopbaanadvisering in de private sector. Ten slotte gaat paragraaf 2.4 in op de maatschappelijke aandacht voor keurmerken en certificering.

\subsection{Inleiding}

Loopbaanadvisering werd in Nederland in 1978 vrijwel tegelijkertijd door Paul van Ede en Frans Claassens geïntroduceerd en is derhalve nog een relatief jong vak. $\mathrm{Al}$ is dat in zekere zin niet juist; loopbaanadvisering werd in de familiekring al eeuwen bedreven. Het wordt echter nog maar kort vanuit particulier initiatief door professionals uitgevoerd. Pas in het begin van de $20^{\text {ste }}$ eeuw verscheen de eerste literatuur van Parsons (1909) over het vakgebied. Het duurde evenwel tot de jaren zeventig voordat loopbaanadvisering in de zakelijke private sfeer in Nederland enige gestalte kreeg.

Loopbaanadvisering op basis van particulier initiatief kwam voort uit de beroepskeuzebegeleiding in het voortgezet onderwijs. Beroepskeuzebegeleiding werd in de gehele westelijke wereld ingezet en zeker in de Angelsaksische landen, waar begeleiding in het onderwijs sterk ontwikkeld is (Watts, 2004). De overheid speelde hierbij in alle landen een primaire rol. Op het gebied van beroeps- 
keuzebegeleiding is er in veel West-Europese landen ook wetgeving ontwikkeld. In Engeland en Finland is deze wetgeving sterk ontwikkeld, om de beroepskeuzeeducatie op scholen te stimuleren. Ook in Frankrijk en Duitsland wordt inmiddels veel gedaan om de beroepskeuze-educatie op scholen door wetgeving te bevorderen. Toch noemt Sultana (2002) loopbaan- en beroepskeuze-educatie een "afgeknotte" professie, als hij analyseert hoe advisering op scholen in de verschillende Europese kennislanden gestalte krijgt. Nog minder aandacht bestaat er voor loopbaanadvisering in het verlengde van volwasseneneducatie, zeker als het gaat om wetgeving op deze deelgebieden. Door de Europese Commissie wordt het gehele vakgebied (beroepskeuze-educatie op scholen, volwasseneneducatie en loopbaanadvisering) gestimuleerd via het Life Long Learning programma. Op zich is deze zienswijze bijzonder fascinerend, maar in de praktijk komt er weinig van terecht omdat er te weinig geld beschikbaar gesteld wordt voor dit doel. De Europese Unie springt wel bij als het gaat om het verstrekken van informatie over het vakgebied en het stimuleren van zelfbegeleiding door ICT en sociale media (Organisation for Economic Cooperation and Development (OECD; 2002).

Vóór de jaren zeventig van de vorige eeuw was het ook in Nederland alleen de overheid die mensen zonder werk via arbeidsbureaus begeleidde naar nieuw werk. De overheid vond in die tijd dat het begeleiden van mensen die op afstand tot de arbeidsmarkt staan een typische overheidstaak is. In de jaren zeventig van de vorige eeuw werd dit monopolie, zowel in Duitsland als in Nederland, door particulier initiatief doorbroken. In Nederland kwam de kentering in 1978, maar het duurde tot de eeuwwisseling voordat er enige ruimte ontstond om overheidstaken op het gebied van loopbaanadvisering door de private sector te laten uitvoeren. In 2002 kwam er een OECD-rapport uit over loopbaanadvisering in verschillende landen van Europa, later gevolgd door een aanvulling door de Europese Commissie 
(Sultana, 2002). In de OECD-rapportage over het Nederlandse beleid werd de privatisering van de loopbaanadvisering op geen enkele manier naar voren gebracht. Dit terwijl de activiteiten die er in de private sector in Nederland op het gebied van outplacement, loopbaanbegeleiding en loopbaancoaching plaatsvonden in die tijd reeds een aanzienlijke bijdrage leverden door circa 100.000 van de 600.000 werkzoekenden te begeleiden. Door de sterke focus van het OECD-rapport op de overheid kwam het rapport voor Nederland tot eenzijdige conclusies. De OECD constateerde dat:

- er slechts beperkte aandacht was voor loopbaanbeleid, vooral door de slechte contacten van het voortgezet onderwijs met de arbeidsmarkt;

- het begeleidingssysteem in Nederland gefragmenteerd was. In feite was er geen sprake van begeleiding, maar vonden er activiteiten plaats die niet onderling verbonden waren;

- vooral in het schoolsysteem, maar ook op andere gebieden, er in Nederland een gebrek aan inzicht was aan wat er nu precies aan begeleiding plaatsvond, bijvoorbeeld op het terrein van monitoring of kwaliteitsborging;

- de rol van de overheid onduidelijk was.

Nederland streefde een van andere West-Europese landen afwijkende besturingsfilosofie na, die gericht was op decentralisatie, marktgerichtheid en privatisering. In het OECD-rapport werd dit aspect over het hoofd gezien.

Om een goed oordeel te vormen over de vraag of en op welke wijze loopbaanadvisering in Nederland zich tot een professie heeft ontwikkeld, is het van belang om niet alleen de bijdrage vanuit de overheid te beschouwen, maar om juist ook onderzoek te doen naar het door de Nederlandse overheid zo sterk benadrukte 
particuliere initiatief. Daarom richt dit hoofdstuk zich op de loopbaanadvisering in Nederland, met de focus op de sterk ontwikkelde private sector.

\subsection{Historische schets van de ontwikkeling van de loopbaanbemiddeling door de overheid in de periode 1978 - 2018}

\subsubsection{De periode 1978-1990: Dominante positie Arbeidsvoorziening en GAK}

Al vóór 1978 namen Arbeidsvoorziening ${ }^{1}$ en de Stichting Gemeenschappelijk Administratie Kantoor ${ }^{2}$ (GAK) een dominante positie in op het terrein van de sociale zekerheid. Deze dominantie duurde voort tot 1990. De 65 arbeidsbureaus, die onder een Directeur-Generaal van het Ministerie van Sociale Zaken vielen, hadden de volgende taken:

1) arbeidsbemiddeling van circa 500.000 à 600.000 werkzoekenden per jaar;

2) beroepskeuzeadviezen voor nieuwe intredende werkzoekenden;

3) scholing van werklozen met een grote afstand tot de arbeidsmarkt (Centrum Vakopleiding);

4) regelen van ontslag via de ontslagtoets; daarnaast kon ontslag ook door de kantonrechter gegeven worden via de 'kantonrechtersformule'.

De stichting GAK ontving de premies van bedrijven en regelde de uitkeringen. De sociale zekerheid functioneerde onder het ministerie in de jaren tot 1990 tot tevredenheid.

2.2.2 De periode 1990 - 2001: Tripartiete Bestuur

\footnotetext{
${ }^{1}$ Arbeidsvoorziening was verantwoordelijk voor de arbeidsbemiddeling in Nederland tot 1990.

2 Stichting Gemeenschappelijk Administratie Kantoor (GAK) was verantwoordelijk voor de uitkeringen in Nederland.
} 
De politiek maakte in 1990 een einde aan de hierboven geschetste structuur van de sociale zekerheid. Door Arbeidsvoorziening uit het Ministerie van Sociale Zaken te lichten en onder een Tripartiet Bestuur te plaatsen, bestaande uit vertegenwoordigers van werkgevers, werknemers en de overheid, werd beter aan de overlegstructuur van het poldermodel voldaan. De overheidsdelegatie bestond uit vertegenwoordigers van drie ministeries te weten: Economische zaken (EZ), Sociale Zaken en Werkgelegenheid (SZW) en Onderwijs, Cultuur en Wetenschap (OCW), alsmede uit de Vereniging Nederlandse Gemeenten (VNG). Het Tripartiete Bestuur werd rechtstreeks onder de minister van SZW geplaatst. De organisatie had aanvankelijk 28 en later 18 tripartiete regiobesturen en daaronder tripartiete plaatselijke besturen voor hetzelfde takenpakket als vóór 1990. Daarnaast bleef Stichting GAK bestaan met dezelfde structuur en hetzelfde doel als voorheen.

\subsubsection{De periode 2001 - 2009: De invloed van re-integratie}

In 2001 werd door de toenmalige regering het lang verwachte besluit genomen om de sociale zekerheid gedeeltelijk te privatiseren ${ }^{3}$. De uitvoering van de sociale zekerheid werd gelegd bij twee semi-overheidsorganen: het Centrum Werk en Inkomen (CWI) en het Uitvoeringsinstituut Werknemer Verzekeringen (UWV). Het Centrum Vakopleiding werd afgeschaft. Van het Arbeidsbureau moest CWI de instroom in de Werkloosheid Wet (WW) en de Wet Arbeid Ongeschiktheid (WAO) overnemen, terwijl het UWV de coördinatie van de uitkeringen van het GAK overnam. Bovendien moest UWV ervoor zorgdragen dat de uitkeringsgerechtigden zo snel mogelijk weer in de maatschappij konden worden ingezet. Daarvoor werd de private markt aangesproken. Mede door de conjunctuuromslag, na de aanslag op het WTC te New York op 11 september 2001, ontstond er een (te) groot aantal re-

${ }^{3}$ Door de wet: Structuur Uitvoeringsorganisatie Werk en Inkomen (SUWI). 
integratie bedrijven, veelal met personeel van de oude arbeidsbureaus, maar ook uit de kring van het GAK. De nieuwe particuliere re-integratie bedrijven werden aangevoerd door KliQ, het grootste bedrijf met 3.500 re-integratie adviseurs. Grote groepen uitkeringsgerechtigden werden begeleid naar nieuw werk. De re-integratieadviseurs werden zodoende collega's van de loopbaanadviseurs, met dien verstande dat de loopbaanadviseurs vooral de particuliere markt bedienden en de re-integratiebureaus hun opdrachten kregen van het UWV en de gemeenten. De reintegratiebureaus organiseerden zich in een sterke branchevereniging, BOREA, die in 2006 fuseerde met de ARBO-dienstverleners tot Boaborea. Deze brancheorganisatie is vervolgens in 2008 met NOBOL $^{4}$ gefuseerd tot de Organisatie voor Vitaliteit Arbeid en Loopbaan (OVAL).

Omstreeks 2006 veranderde de arbeidsmarkt echter drastisch als gevolg van de hoogconjunctuur en de vergrijzing van de beroepsbevolking (de eerste babyboomers gingen met vervroegd pensioen). Hierdoor werd de factor arbeid weer schaars. Het ministerie van SZW besefte dat veel meer maatwerk nodig was om de overgebleven uitkeringsgerechtigden op een goede manier aan blijvend werk te helpen. Daarom werden Individuele Re-integratie Overeenkomsten (IRO) ${ }^{5}$ geïntroduceerd. De IRO-cliënten werden deels door de re-integratiebedrijven begeleid, maar voor het overgrote deel $(84 \%)$ door zelfstandige loopbaanadviseurs (zzp'ers) en outplacementbureaus. In 2006 werden, volgens NOBOL, 26.000 IROcliënten begeleid door 2.200 bureaus (inclusief zzp'ers).

\footnotetext{
${ }^{4}$ De branchevereniging NOBOL is de afkorting voor "Nederlandse Organisatie van Bedrijven voor Outplacement en Loopbaanbegeleiding".

${ }^{5}$ Individuele Re-integratie Overeenkomsten (IRO) werden door de overheid veelal afgesloten voor hoger opgeleid personeel.
} 
Een tweede gevolg van de relatieve schaarste aan arbeidskrachten was dat de re-integratiebedrijven minder opdrachten ontvingen van het UWV en de gemeenten, waardoor zij opdrachten gingen verwerven in de particuliere sector en daardoor directe concurrenten werden van de traditionele loopbaanadviesbureaus.

\subsubsection{De periode 2009 - heden: Fusie CWI en UWV}

In 2009 fuseerden CWI en UWV. In feite werd CWI een deel van UWV. UWV bleef een zelfstandige uitvoeringsorganisatie, direct onder de verantwoordelijkheid van de minister van SZW. UWV kreeg drie organisaties onder één bestuur, te weten:

1) het UWV Werkbedrijf, met circa 2.700 personeelsleden en 33 vestigingen voor inschrijving van werkzoekenden, arbeidsbemiddeling, en later nog eens 2.500 extra jobcoaches voor langdurige werkloosheid;

2) de uitkeringsinstantie voor WW- uitkeringen;

3) de Sociaal Medische Dienst voor de beoordeling van klanten voor Wet Werk en Inkomen naar Arbeidsvermogen (WIA) en Wet Arbeidsongeschiktheidvoorziening Jonggehandicapten (Wajong), voor actieve deelname aan het maatschappelijke verkeer.

Door de veranderde structuur werden de taken van de re-integratiebureaus deels overgenomen door UWV, waardoor de privatisering van het sociale zekerheidstelsel deels teruggedraaid werd en veel re-integratie bedrijven failliet gingen. Voorts werden de voorwaarden voor het werken als zzp'er aangepast. Onder meer was tijdens de wachttijd van de WIA zzp geen dienstbetrekking in de zin van artikel 29b van de ziektewet. Derhalve kon hiervoor de no-risk-polis van toepassing zijn. De no-risk-polis was aan de orde bij een WIA-uitkering als de werknemer zijn werk had hervat bij de eigen werkgever of tijdens de wachttijd of na 
de eerste WIA-dag bij een andere werkgever. Ook de ziektewet zelf werd per 1 januari 2013 aangepast. Om binnen de ziektewet te vallen moest 65\% van het zogenaamd maatinkomen verdiend worden met algemeen geaccepteerde arbeid, nadat de arbeidsongeschiktheid 52 weken had geduurd én de verzekerde geen werkgever meer had. Per 2015 werden tevens de Participatiewet met de daarbij behorende wetgeving (Wet Arbeidsgehandicapte Werknemers (WAGW), de Wet Banenafspraak en Quotum Arbeidsbeperkten) ingevoerd. Deze drie wetten werden ingevoerd om het grote aantal arbeidsongeschikten beter te organiseren.

De Participatiewet dient ervoor om arbeidsongeschikten die geen minimumloon kunnen verdienen, toch maatschappelijk te laten bijdragen. Via deze wetgeving werd de verantwoordelijkheid voor de uitvoering verlegd van UWV naar de afzonderlijke gemeenten. De aan de Participatiewet gelinkte WAGW werd uitgewerkt door de Wet Banenafspraak waarbij via het Sociaal Akkoord6 ${ }^{6}$ werd afgesproken dat 125.000 extra banen voor arbeidsgehandicapte werknemers zouden worden gecreëerd, waarbij er 100.000 banen door het bedrijfsleven zouden worden ingebracht en 25.000 banen door de overheid gecreëerd zouden worden.

Mocht dit aantal extra banen niet gehaald worden dan zou de Wet Quotum Arbeidsbeperkten in werking treden, waarbij alle organisaties gedwongen werden om vijf procent van hun personeel uit arbeidsgehandicapte werknemers te laten bestaan. Deze laatste wet is éénmaal voor korte tijd ingevoerd, maar behoeft anno 2018, gezien de grotere vraag naar personeel, voorlopig niet meer toegepast te worden.

\footnotetext{
${ }^{6}$ Het Sociaal Akkoord wordt gesloten tussen de sociale partners (VNO-NCW en de vakbeweging) en de overheid.
} 


\subsection{Korte historie van de ontwikkeling van loopbaanadvisering in de private} sector 1978 - 2018

In het boekje "Loopbaanbegeleiding in de Praktijk", een bloemlezing van case studies van loopbaanadviseurs die door Career Management Institute (CMI) gecertificeerd waren, werd door Hamaker en Kruythoff (2007, p. 122) inzake de ontwikkeling van loopbaanadvies in Nederland geconstateerd dat "Outplacement door velen in de beginjaren 1980 beschouwd werd als een bezigheid". Het was toen nog niet duidelijk of loopbaanadvisering ooit een professie zou worden.

In 1978 begon Paul van Ede als eerste in Nederland gesprekken te voeren met topmanagers in het bedrijfsleven die in conflict waren gekomen met collega's en gedwongen werden of zich gedwongen voelden om te vertrekken. In veel gevallen werd het als gezichtsverlies ervaren, of als een inbreuk op de integriteit van betrokkene, of als een voor het bedrijf schadelijke zaak, wanneer zo'n conflict in de openbaarheid zou komen. In stilte werd dus naar een fatsoenlijke oplossing gezocht. Paul van Ede bood dergelijke oplossingen aan door, samen met de tot vertrekken gedoemde manager, na te gaan waar een zinvolle voortzetting van diens loopbaan zonder gezichtsverlies mogelijk zou zijn. Toen Hans Leewens (als mededirecteur) en de bedrijfspsycholoog Piet Colijn zich in de beginjaren '80 bij Paul Van Ede voegden, werd het begeleidingsproces geleidelijk aan gestructureerd naar het voorbeeld van het Engelse loopbaanadviesbureau Sanders en Sydney te London en professioneel opgezet. Zo ontstond het eerste loopbaanadviesbureau in Nederland: "Van Ede \& Partners". In die tijd werd Van Ede \& Partners een 'outplacement bureau' genoemd.

In 1978 kwam Frans Claessens terug van een studiereis door de Verenigde Staten, waar hij bij verschillende bureaus had gezien hoe loopbaanadvies daar werkte. Bij terugkomst in 1978 richtte hij het Raadgevend Bureau Claessens (R.B.C.) 
op. Goed voorbeeld doet goed volgen en in 1982 startten Van der Haas en Van Hecke hun outplacementbureaus. Hoewel al snel daarna een aantal kleinere bureaus werd opgericht, bleven de genoemde vier bureaus gedurende de jaren ' 80 'de grote vier' die het loopbaanadviesbeeld in ons land bepaalden. Elk van deze vier grotere bureaus werd gekenmerkt door een eigen stijl en sfeer. Bij Van Ede \& Partners werd van meet af aan de nadruk gelegd op de persoon en op diens persoonlijke individuele kwaliteiten, talenten in het jargon van dat bureau. Bij de marktoriëntatie van de cliënt werd en wordt bij Van Ede vaak gebruik gemaakt van het netwerk van de adviseurs. Het bureau richtte zich in hoofdzaak op de hoger opgeleiden in de markt. In 1992 werd speciaal voor het topsegment Top Executive Coaching opgericht. Raadgevend Bureau Claessens en Van der Haas hadden een wat meer Amerikaanse werkwijze en richtten zich primair op de noodzaak om met hun kandidaten op efficiënte wijze een nieuwe baan te vinden. De marktoriëntatie van deze bureaus was hierdoor voornamelijk gericht op het bedrijfsleven. Bij Phoenix (het vroegere Van Hecke) werd meer nadruk gelegd op spiritualiteit en op een meer psychologische, soms zelfs therapeutische, begeleidingswijze.

Toen in 1989 door Frans Claessens het initiatief genomen werd om een branchevereniging op te richten, waren er reeds achttien loopbaanadviesbureaus van enige betekenis die gehoor gaven aan zijn oproep. In 1990 volgde de oprichting van NOBOL met deze achttien kwaliteitsbureaus. Tezelfdertijd werd door een aantal adviseurs de beroepsvereniging Noloc $^{7}$ opgericht. Aanvankelijk werd outplacement gezien en toegepast als een geruisloze afvloeiingsmethode voor topmanagers die in conflict waren geraakt of door fusies en overnames overbodig

\footnotetext{
${ }^{7}$ Noloc is de naam van dé beroepsvereniging voor loopbaanadvies in Nederland. Noloc fuseerde in 2006 met de beroepsvereniging voor beroepskeuzeadviseurs. Voordien was Noloc de afkorting van de naam: Nederlandse Orde van Loopbaan en Outplacement Consultants (NOLOC).
} 
waren geworden. Spoedig echter bleek dat de methodiek van identificatie van individuele vaardigheden en talenten en de systematische verkenning en benadering van de arbeidsmarkt ook voor minder hoog in de bedrijfshiërarchie geplaatsten een succesvolle aanpak was. Outplacement werd als instrument bij de uitstroom van werknemers, mede door de invloed van de vakbeweging, al snel algemeen toegepast, ongeacht het opleidingsniveau of de positie in het bedrijf van de betrokkenen. Het instrument bleek bovendien niet alleen individueel, maar ook in groepsverband toepasbaar.

\subsubsection{Outplacement in de private sector}

Het grondprincipe van outplacement was eenvoudig. Het begon vrijwel altijd met een zelfanalyse in een biografische vormgeving. Vaak werd de zogenoemde 'analyse van succesverhalen' gebruikt om tot een identificatie van sterke en zwakke eigenschappen te komen. De vormgeving varieerde van een meer of minder psychologisch georiënteerde open gespreksvoering tot gestandaardiseerde en via de computer toepasbaar gemaakte beschrijvende en voorspellende testen en modellen zoals de Personality and Preference Inventory (PAPI), die reeds in de jaren tachtig bij van Ede \& Partners werd gebruikt.

Als het individuele tableau van persoonlijke kwaliteiten, vaardigheden, wensen en verwachtingen van de cliënt in kaart gebracht was volgde het tweede deel van de begeleiding: de marktoriëntatie en het toespitsen op een aantal mogelijkheden in de markt, uitmondend in het sollicitatieproces. Dit onderdeel van de begeleiding begon veelal met de identificatie van het deel van de arbeidsmarkt dat voor de betrokken cliënt mogelijk van belang was en het verwerven van inzicht in het functioneren van die deelmarkt. Daarmee werd de basis gelegd voor een gerichte, efficiënte en daardoor vaak effectieve zoektocht naar een passende nieuwe 
baan. Sollicitatietraining, zoals de training in het opstellen van een $\mathrm{CV}$, het schrijven van brieven, het leggen van contacten, het voeren van gesprekken en het onderhandelen over arbeidsvoorwaarden, vormde meestal een vast onderdeel van de begeleiding. Een methodiek die speciale aandacht vroeg betrof het 'netwerken'. De zorgvuldige opbouw van een persoonlijk netwerk, inclusief alle mogelijkheden om op een discrete en geaccepteerde wijze in gesprek te komen met in de persoonlijke strategie passende sleutelfiguren, vormde vaak de kern van dit proces. De begeleidende consultant vervulde hierbij de rol van raadgever, klankbord, oefenmeester en vraagbaak.

Het spreekt welhaast vanzelf dat bij de toepassing van dit grondprincipe van het outplacementproces een reeks aan variaties en toegepaste methodieken en instrumenten voorkwam. Elk bureau en elke individuele adviseur had een eigen visie en aanpak. Bij de één lag het accent op het eerste gedeelte van het begeleidingsproces. Daar speelden vooral psychologisch georiënteerde opvattingen en werkwijzen een voorname rol. Wanneer de door een ontslagsituatie geschokte en ontredderde cliënt eerst maar weer 'goed in zijn vel' kwam te zitten, dan volgde de rest vanzelf, was de mening van velen. Bij anderen lag het accent meer op een pragmatische werkwijze en vormde een doelstelling als het vinden van 'de best mogelijke baan in de kortst mogelijke tijd' de maat van alle inspanning.

\subsubsection{Uitbreiding door de outplacement formule}

Het succes van de commerciële outplacementbegeleiding was wellicht mede verklaarbaar doordat de werkgelegenheid gedurende de jaren tachtig en het begin van de jaren negentig, ten gevolge van economische recessie, aanmerkelijk afnam. Dit was eveneens het geval na de financiële crisis van 2008. Velen raakten door bedrijfssluitingen en reorganisaties hun baan kwijt, of werden met ontslag bedreigd. 
De arbeidsmarkt werd gekenmerkt door een aanzienlijk aanbodoverschot, wat het veroveren van een bruikbaar alternatief voor de verloren arbeidspositie niet eenvoudig maakte. Outplacement was in macro-economische termen een anticyclisch vak: in een recessieperiode was er veel vraag naar outplacementbegeleiding; in een fase van spanningen op de arbeidsmarkt nam die vraag af en nam de vraag naar andere vormen van loopbaanondersteuning, zoals loopbaancoaching en -begeleiding ${ }^{8}$ juist toe, omdat er weinig arbeidspotentieel voorhanden was. Hierdoor werd iedereen die kon werken zo effectief mogelijk ingezet.

Het gevolg was dat, vooral in de jaren tachtig en negentig, er een groot aantal loopbaanadviesbureaus werd opgericht. In die jaren telde de branche 73 formeel bij het Ministerie van SZW geregistreerde bureaus, waarvan er vele meerdere vestigingen hadden, verspreid over het land. Daarnaast waren er ook nietgeregistreerde bureaus, waardoor een schatting van 125 tot 150 outplacementbureaus in ons land niet overdreven is. Daarmee verkreeg outplacement in Nederland vanuit de private sector in vele opzichten een leidende positie in Europa en zelfs in de wereld. Rond 1990 bedroeg het aantal outplacementbureaus per miljoen inwoners in de voornaamste outplacementlanden in de wereld: Frankrijk: 1; Verenigd Koninkrijk: 3; Verenigde Staten: 7 en Nederland 10 bureaus per miljoen inwoners.

\subsubsection{Professionalisering van de branche in de private sector}

Om de professionaliteit van de snelgroeiende branche te borgen richtten de voornaamste loopbaanadviesbureaus begin 1990 de brancheorganisatie NOBOL op. Het aantal bij NOBOL aangesloten bureaus bleef lange tijd tamelijk beperkt. Echter, de participatie van vrijwel alle belangrijke bureaus, onder aanvoering van 'de grote

\footnotetext{
${ }^{8}$ Zie voor de definities die CMI hanteert Hoofdstuk 1 van dit proefschrift en www.cminl.nl.
} 
vier' (Van Ede, Claessens, van der Haas en Phoenix), leidde tot een gezamenlijk marktaandeel van zeventig procent, waardoor de jonge brancheorganisatie snel een duidelijk gezicht kreeg. Tezelfdertijd werd door een aantal bij die bureaus aangesloten individuele beroepsbeoefenaren NOLOC opgericht. Het kostte aanvankelijk nogal wat moeite om individuele beroepsbeoefenaren ervan te overtuigen dat samenwerking van groot belang was voor de professionele ontwikkeling van de beroepsuitoefening. Aan het einde van het eerste bestaansjaar van NOLOC telde men nog geen veertig leden uit een totaal van naar schatting ongeveer 600 beroepsbeoefenaren. Pas na drie jaar was het ledental gestegen tot honderd.

Aanvankelijk bleek het ook moeilijk om te komen tot een gezamenlijke organisatievorm tussen NOBOL en NOLOC. Er bestond aan beide zijden wel begrip voor het verschil in belangen tussen de bureaus (werkgevers) en de adviseurs (veelal werknemers van deze bureaus). Na ruim drie jaar overleg tussen beide verenigingen kwam men tot het inzicht dat er, vooral met het oog op de wildgroei in de markt, ook een duidelijk gemeenschappelijk belang was: de professionalisering van de vakbeoefening. Dit was het begin van een goede onderlinge samenwerking. Het resultaat was een gestructureerd overleg en een gezamenlijk bestuurslid als trait d'union.

In 1994 sloot NOLOC zich als organisatie aan bij de International Association of Outplacement Professionals, later ACP International. ACP International ontwikkelde een mondiale federatieve structuur, waarin naast Nederland ook de Verenigde Staten, Canada en het Verenigd Koninkrijk vertegenwoordigd waren. ACP International had bovendien individuele leden in meer dan twintig andere landen. Ook NOBOL initieerde in de jaren 1994 - 2000 veel initiatieven om de career management-gemeenschap internationaal dichter bij elkaar te brengen. NOBOL 
nam het initiatief om in Europa de European Association for Outplacement (EAO) op te richten. Enige jaren later fuseerde EAO met AOCF uit de Verenigde Staten tot Association of Career-Management Firms International (AOCFI). Afgesproken werd dat AOCFI telkens na twee jaar zou wisselen van voorzitter, steeds ofwel een Amerikaan ofwel een Europeaan. In 2007 trok NOBOL zich echter uit het internationale circuit terug, vanwege de hoge kosten van het lidmaatschap en de geringe voortgang die werd bereikt.

Als een volgende belangrijke stap in de professionalisering van outplacement- en loopbaanbegeleiding in Nederland werd in 1994 door NOBOL en NOLOC een belangrijk initiatief genomen. Het doel was om te komen tot toetsing van de vakbekwaamheid en vervolgens tot de certificering van loopbaan-professionals. Het duurde echter tot 1997 voordat het Career Management Institute Netherlands (CMI) werd opgericht, als onderdeel van de Board for Career Management International (IBCMC), later omgedoopt tot Institute for Career Certification International (ICCI). CMI werd dé certificerende instelling in Nederland die de professionaliteit en de vakbekwaamheid van loopbaanadviseurs periodiek toetste aan door IBCMC opgestelde kwaliteitscriteria. Van de gecertificeerde loopbaanadviseurs werd een officieel en openbaar register bijgehouden. Zij onderscheiden zich door het predicaat Register Loopbaan-professional (RL), daarmee aangevend dat ze voldoen aan onafhankelijk getoetste, internationaal geldende kwaliteitscriteria. Na een aarzelend begin mocht CMI zich verheugen in een snel toenemende belangstelling.

Steeds vaker vroegen opdrachtgevers, zowel in de private sector als bij de overheid, bij de uitvoering van een opdracht om gekwalificeerde RL's, die na 2010 onder het toeziend oog van de Raad voor Accreditatie door CMI gecertificeerd 
werden. Volgens DNV GL ${ }^{9}$ werden in de periode 1997 - 2018 circa 880 loopbaanadviseurs initieel gecertificeerd op vakbekwaamheid.

\subsubsection{Van 'cure' naar 'care' in de private sector}

Outplacement als het planmatig begeleiden van het vaak gedwongen vertrek van werknemers evolueerde eind jaren negentig in de richting van het planmatig vaststellen van wat de juiste functie is voor de desbetreffende werknemer en een methodische hulp (loopbaancoaching), om die persoon steeds op een juiste plaats te houden. Daarbij bleek het instrument niet alleen van waarde bij de toepassing van een effectieve en efficiënte oplossing in het geval van conflict of overbodigheid, maar vooral ook bij het voorkomen van problemen. Met andere woorden, outplacement evolueerde deels van een curatief naar een meer preventief instrument, onder de verzamelnaam 'loopbaanadvisering'. Het aantal opdrachten, met een nadrukkelijk preventief oogmerk, nam aanzienlijk toe. Tijdige bijsturing, niet gericht op de uitstroom, maar op de interne doorstroom van medewerkers (loopbaanbegeleiding), vormde daarbij het leidmotief.

Daarbij kwam dat steeds meer hooggeschoolde jonge medewerkers bij hun leidinggevenden aandrongen op toestemming om gebruik te maken van vormen van loopbaanbegeleiding en loopbaancoaching. Daarbij wilden zij vaak begeleid worden door een onafhankelijke derde met de vraag of zij nog wel op de juiste plaats en bij het (voor hen) juiste bedrijf of organisatie zaten. Met andere woorden: paste de organisatie waar zij werkten en de in dat bedrijf uitgeoefende functie nog wel bij de ontwikkeling van de vaardigheden en persoonlijkheid van de betrokkene. Daar-

\footnotetext{
${ }^{9}$ DNV GL (Det Norske Veritas Germanischer Lloyd), een wereldwijde certificerende instelling met een Noors hoofdkantoor, onder meer gespecialiseerd in persoonscertificering, heeft de operationele verantwoordelijkheid van CMI in 2014 overgenomen.
} 
bij lag het initiatief bij de werknemer. Goed lopende bedrijven, die, gezien de ontwikkelingen op de arbeidsmarkt, op een goede manier met hun personeel wilden omgaan, maakten rond de eeuwwisseling gebruik van deze preventieve aanpak. Daardoor nam outplacement als uitstroommechanisme (curatief instrument) in belang af en nam de vraag naar loopbaancoaching toe. Natuurlijk bleef outplacement als zodanig bestaan, maar de accenten van het bedrijfsbeleid tendeerden meer naar vormen van loopbaanbegeleiding en loopbaancoaching in tijden van schaarste aan arbeidskrachten, zoals in de jaren rond de eeuwwisseling en in de jaren 2005 tot 2008 alsook nu weer in 2017 - 2018.

\subsubsection{Gevolgen van de verschuiving van outplacement naar loopbaanbegeleiding}

De genoemde veranderingen in de arbeidsmarkt rond de eeuwwisseling gingen ook gepaard met veranderingen in het werk van de loopbaanadviseurs. Aanvankelijk was het bij outplacement vooral de werkgever die het initiatief nam tot actie, tot afvloeiing, uitstroom, ontslag wegens reorganisatie, disfunctioneren of de onverenigbaarheid van karakters. Tegen de eeuwwisseling kwamen vastgelopen, of zich in de steek gelaten voelende, werknemers er steeds meer toe zelf hulp te zoeken. Zij hadden vragen als: 'Hoe beslis ik wat van blijvende waarde is voor mijzelf, in een samenleving die ongeduldig is en zich alleen op dit moment richt?' ‘Hoe kan ik mijn doeleinden op lange termijn nastreven in een economie waarin het alleen om de korte termijn gaat?' 'Hoe kan ik wederzijdse trouw en betrokkenheid bewaren in organisaties die voortdurend uiteenvallen of opnieuw in elkaar worden gezet?' ‘Waarom wordt van mij een steeds grotere inzet gevraagd, terwijl er steeds minder aandacht voor mijn belang tegenover staat?'

De markt kreeg daarmee steeds duidelijker ook eigenschappen van een 'retailmarkt'. Het waren individuele werknemers die de eigen loopbaan in een 
breder, zingevender verband wilden plaatsen, waardoor keuzes meer inhoud en structuur kregen. Het zoeken naar zingeving werd na de eeuwwisseling steeds vaker de kern waarom de hulpvraag draaide. Dat werd nog versterkt door een situatie op de arbeidsmarkt die het er voor werkgevers niet eenvoudiger op maakte om snel aan voldoende adequaat gekwalificeerd personeel te komen: de veelvuldige personeelstekorten in de jaren rond de eeuwwisseling en in de periode 2005 - 2008 maakten het beslist eenvoudiger een passende nieuwe werkkring voor de werkzoekende te vinden en te veroveren. In 2018 zien we hetzelfde fenomeen.

Loopbaanadvies veranderde aldus van karakter. Het was in de meeste gevallen allang geen ad hoc vraag meer, maar een gestructureerd proces. De begeleidingsvraag bij het probleem 'Wat zou een zinvolle volgende stap in mijn loopbaan kunnen zijn?' verbreedde zich. Het vloeide uit tot veel meer omvattende vragen in termen van 'zelfontplooiing' en 'zijnskwaliteit'. Het ging bij loopbaanadvisering allang niet meer alleen om het op de hoogte zijn van trends in de markt en het inzicht hebben in de vaardigheden en gedragingen die een volgende werkgever nodig zou hebben.

Loopbaanadvies betekende in toenemende mate dat de kandidaten zich niet alleen bewust waren van hun eigen bekwaamheden en hun sterke en zwakke punten, maar dat men over een plan beschikte voor het verbeteren van zijn prestaties en zijn duurzame inzetbaarheid op de lange termijn (Life Long Learning). Het was een zoeken naar nieuw evenwicht in de voor velen verstoorde balans tussen werk en privé, tussen welvaart en welzijn, naar een gelijkwaardige participatie aan het arbeidsproces door mannen en vrouwen. 
In veel opzichten was het jaar 2008 een keerpunt. Door de financiële crisis ontstond een aanzienlijke werkloosheid. In het verleden konden de outplacementbureaus hiervan ten zeerste profiteren. In de periode 2008 - 2014 was dit anders. Door gebrek aan koopkracht kwam de gehele Nederlandse economie in problemen. Loopbaanadvisering was geen uitzondering. De uurtarieven voor begeleiding en coaching kelderden, waardoor vele adviseurs op straat kwamen te staan. Velen besloten als zzp'er voor zichzelf te beginnen tegen nog lagere tarieven. Zij konden het hoofd vaak alleen boven water houden door van huis uit te werken en pensioenpremies en zorgverzekering te minimaliseren.

De branchevereniging NOBOL verloor circa de helft van haar leden (die als zzp'er zelfstandig verder gingen) en besloot met Boaborea (de re-integratiebranche en de ARBO-diensten) te fuseren tot OVAL. De beroepsvereniging NOLOC koos in 2008 ook voor fusie met de beroepsvereniging voor beroepskeuzeadviseurs (BKA). Omdat men verkoos om zich te profileren onder de naam Noloc (geschreven met kleine letters), werd NOLOC feitelijk met 600 beroepskeuzeadviseurs uitgebreid, waardoor de vereniging van circa 1.200 tot 1.800 leden uitgroeide en daarna verder uitgroeide tot 2.600 leden, waaronder veel zzp'ers.

Het succes van de groei bij Noloc werd bevorderd door: een betaalbare contributie, ook voor startende zzp'ers; een goed en herkenbaar product: kwaliteitsbevordering door intervisie in de regio; en een goede positionering in de markt: "Noloc Erkenning" als beeldmerk voor kwaliteit, ondersteund door een verplichte basistoets. De toets diende gezien te worden als toetssteen voor het lidmaatschap en werd gefinancierd zonder verhoging van de contributie. Dit laatste werd door de leden op prijs gesteld, omdat de markt het beeldmerk accepteerde. Door de snelle groei van Noloc leek de branche zich succesvol te ontwikkelen. De werkelijkheid was echter anders, omdat veel zzp'ers vanuit een vaste baan door de 
crisis gedwongen werden om voor zichzelf te beginnen tegen lagere tarieven dan de bureaus. Voor zzp'ers die geen bijzonder aanbod hadden, werd de onderhandelingspositie voor het verkrijgen van opdrachten problematisch. Door zich te onderscheiden in de markt, konden meer opdrachten worden verkregen en hogere tarieven bedongen worden. Niet voor niets was er steeds meer aandacht voor keurmerken en certificering om het onderscheid tussen adviseurs aan te tonen.

Thans gaat het weer goed in Nederland; voor de sector wellicht te goed. De werkloosheid neemt in rap tempo af. Natuurlijk is de sector gewend aan de gevolgen van conjunctuuromslagen en tracht het een anticyclisch beleid te voeren. De tarieven zijn echter over het algemeen niet voldoende aangetrokken, waardoor de sector nog immer onvoldoende rendeert.

\subsection{Maatschappelijke aandacht voor Keurmerken en Certificering}

\subsubsection{Loopbaanadvisering zoekt kwaliteit}

Onder invloed van het denken over kwaliteitsgaranties, die voor vele industriële producten essentieel waren, werd in het begin van de jaren negentig ook voor de zakelijke dienstverlening waarde gehecht aan het behalen van een ISO 9001 certificaat. Dienstverleners als Randstad waren er snel bij om zich hiermee voor uitzendwerk te onderscheiden. Toch bleek het effect voor de zakelijke dienstverlening als geheel gering. Opdrachtgevers waren niet onder de indruk van de meerwaarde van het certificaat. Het heeft zeker tien jaar geduurd voordat er een nieuwe impuls aan het kwaliteitsdenken gegeven werd.

Ook bij NOBOL werd de wens om tot een onafhankelijk keurmerk te komen voor de branche manifest. NOBOL zocht samenwerking met andere dienstverleners (interim management, werving en selectie, mediation) om gezamenlijk een certificerende instelling voor adviserende dienstverlening van de grond te krijgen. 
Aanvankelijk met succes, werd de Certificerende Instelling voor Kennisintensieve Dienstverlening (Certiked) opgericht om kennisintensieve dienstverlenende bedrijven te certificeren op basis van ISO 9001. Toen Certiked overgenomen werd door CEDEO, besloot NOBOL in 2006 de kwaliteitstoetsing volledig uit handen te geven door CEDEO te benoemen als onafhankelijke auditor, die tevens het tevredenheidsonderzoek voor zijn rekening nam. Inmiddels zijn alle NOBOL (thans OVAL) bureaus verplicht om aan het CEDEO-onderzoek mee te doen. Bij Noloc was dezelfde tendens zichtbaar met de eerdergenoemde Noloc-erkenning.

Voor CMI was de maatschappelijke aandacht voor keurmerken en certificering van groot belang. Hoewel rond de eeuwwisseling door de branche werd aangevoerd dat certificering weinig toegevoegde waarde heeft, omdat opdrachtgevers weinig waarde toekennen aan certificering, verandert deze instelling langzaam maar gestaag. Met name de overheid vindt certificering van haar loopbaanadviseurs belangrijk, hetgeen zich uit in het feit dat alle loopbaanadviseurs binnen de overheid zich door CMI moeten laten certificeren. Andere opdrachtgevers zijn kritischer, met name als het gaat om een goede prijs/kwaliteitsverhouding. Zij wensen transparantie inzake de kwaliteit van bureaus. Keurmerken en certificering zijn dan essentieel.

\subsubsection{CMI in een nieuwe fase}

Bij CMI was het uitgangspunt steeds dat kwaliteit toetsbaar dient te zijn. In de eerste jaren van de CMI-certificering vond de toets intercollegiaal plaats, wat vraagtekens opriep over de onafhankelijkheid van de toetsing. In 2007 werd bij CMI de vraag gesteld of een certificerende instelling die 120 gecertificeerde adviseurs telde, wel voldoende levensvatbaar was om zich te handhaven, gezien het geringe aantal aanmeldingen voor certificering. Het antwoord kwam uit onverwachte hoek: 
namelijk van NOBOL en Noloc samen. De beide directeuren van NOBOL en Noloc stelden zich beschikbaar om als bestuur CMI als stichting een kans te geven om verder te groeien. CMI koos ervoor om dit te doen door de certificering onder accreditatie te stellen, met een toetsschema op basis van ISO 17024

De normatieve toetsing berust op de toetsing van een dossier aan het beroepsprofiel, bestaande uit een matrix van taken, kennisfactoren en competenties van de loopbaanprofessional. Daarvoor nam het CMI-bestuur een aantal maatregelen om certificering meer aantrekkelijk te maken, zonder de kwaliteit van de toetsing aan te tasten. De kandidaten kregen meer verantwoordelijkheid voor hun eigen certificering; in het verleden moesten de mentoren het dossier van de kandidaat verdedigen; dat doen de kandidaten nu zelf. De toetsingscommissie werd geherstructureerd: de onafhankelijke voorzitters van de toetsingscommissies werden betrokken uit academische kring. Deze werden bijgestaan door twee (later één) expert(s), die werden betrokken uit de kring van CMI-mentoren. Er ontstonden vier regionaal gespreide toetsingscommissies, waardoor de toetsing regionaal kon plaatsvinden. De competenties werden door de mentoren opnieuw bekeken in het licht van de verbreding van het vakgebied. Naast de aandacht voor loopbaanbegeleiding, outplacement en re-integratie werd meer gefocust op de certificering van loopbaancoaches. Het dossier werd gedigitaliseerd. En het bestuur nam de marketing van CMI zelf ter hand.

Naast veel aandacht voor de primaire betrokkenen, zoals de adviseurs van Noloc, NOBOL en Boaborea, nam het bestuur initiatieven om ook de adviseurs van mobiliteitsbureaus en adviseurs in overheidsdienst voor certificering te interesseren. Ook de opdrachtgevers moesten door erkende keurmerken overtuigd worden van het nut van certificering. Dat betekende dat de kwaliteit van de dienstverlening transparant gemaakt moest worden door de certificering. CMI wilde zich op deze 
wijze in de markt zetten als een naar buiten gekeerde instelling en als de autoriteit op het gebied van certificering van loopbaanadviseurs. Om dit te bevestigen liet CMI zich accrediteren door de Raad voor Accreditatie. Dat werd in 2010 gerealiseerd.

\subsubsection{CMI koos voor toekomstige samenwerking}

Sinds begin 2013 zijn er onderhandelingen gaande tussen beroepsvereniging Noloc en CMI. De verschillende belangen en uitgangspunten, maar vooral de strenge eisen van de ISO-normering waaraan de certificering moet voldoen, zijn er de oorzaak van dat een volledig samengaan van Noloc en CMI lang op zich laat wachten. Op dit moment ziet het er naar uit dat de certificering uitgevoerd blijft worden volgens de strenge ISO-normering, maar dat de stichting CMI in 2020 bij Noloc zal worden ondergebracht. Om de onafhankelijkheid te waarborgen zal de certificering onder toezicht staan van een onafhankelijke commissie. Iedere loopbaanadviseur kan zich bij CMI laten certificeren; een Noloc-lidmaatschap is hiervoor niet verplicht. Om lid van Noloc te worden, ziet het ernaar uit dat certificering op vakbekwaamheid een eis wordt. Ook wordt momenteel gewerkt aan een nieuwe invulling van het toetsschema. 



\section{HOOFDSTUK 3}

\section{DE ONTWIKKELING NAAR EEN PROFESSIE}

\subsection{Inleiding}

In een nieuwe beroepsgroep, zoals loopbaanadvisering, is de neiging om zich te ontwikkelen veelal sterk aanwezig. Zo ontstond er al tien jaar nadat Paul van Ede en Frans Claessens, onafhankelijk van elkaar, het vak in 1978 in Nederland geïntroduceerd hadden, een discussie tussen vakgenoten over het oprichten van een branchevereniging. De nieuwe branchevereniging zou volgens sommigen, waaronder Claessens, de belangen van de branche moeten uitdragen door een lobby in de richting van de overheid. Anderen, waaronder Van Ede, vonden juist dat het van primair belang was om een beroepsvereniging op te richten, waardoor de kwaliteit van de uitoefening van het vak zo goed mogelijk gewaarborgd kon worden.

Beide stromingen kwamen aan bod en na een uitgebreide discussie werd in het najaar van 1989 besloten om zowel de branchevereniging NOBOL $^{1}$ als de beroepsverenging $\mathrm{NOLOC}^{2}$ op te richten. Beide verenigingen hadden tot doel om zo snel mogelijk de ontwikkeling naar een professie in te zetten door professionalisering van het vakgebied. De branchevereniging richtte zich voornamelijk op de institutionele inbedding van het vakgebied door aansluiting bij

\footnotetext{
${ }^{1}$ NOBOL staat voor Nederlandse Organisatie voor Outplacement en Loopbaanbegeleiding en fuseerde in 2009 met Boaborea (de branchevereniging voor re-integratie en Arbo) tot OVAL (de branchevereniging voor Outplacement, Vitaliteit, Arbodiensten en Loopbaan), zich noemende de Branchevereniging voor duurzame inzetbaarheid.

${ }^{2}$ NOLOC staat voor Nederlandse Organisatie voor Loopbaan en Outplacement Consultants, maar is sinds 2005 de naam van de beroepsvereniging en wordt geschreven als Noloc.
} 
de werkgeversvereniging VNO-NCW33. Ook werd nadruk gelegd op de ontwikkeling van een visie en missie, een gedragscode en een commissie van beroep. De beroepsvereniging koos voor de inhoudelijke versterking van het vak van loopbaanadviseur door het instellen van intervisiegroepen. Ook werd door Noloc enige jaren na de oprichting een zogeheten 'Body of Knowledge and Skills' ontwikkeld om de taken, de kennisgebieden en de competenties voor het vakgebied vast te stellen. Enige jaren later besloot Noloc zelfs om haar leden na drie jaar lidmaatschap 'Noloc erkend loopbaanprofessional' te noemen. In dat verband geeft De Sonnaville (2005) in zijn proefschrift over organisatieontwikkeling aan dat hij 'professionaliseren' op het microniveau ziet als een proces waarlangs een individuele beroepsbeoefenaar zich ontwikkelt tot een professional. Daar was het Noloc ook om te doen. De ambitie om zich te ontwikkelen tot een 'professie' was bij de beroepsgroep dus al vanaf het begin aanwezig.

Om te onderzoeken in welke mate loopbaanadvisering zich tot een professie heeft ontwikkeld wordt in dit hoofdstuk allereerst bestudeerd wat de wetenschap precies onder een professie verstaat. Vervolgens wordt onderzocht in welke mate loopbaanadvisering zich op dit moment tot een professie ontwikkeld heeft in vergelijking met een aantal andere beroepsgroepen die doorgaans als een professie worden gezien. Daartoe zal in de wetenschappelijke literatuur worden gezocht naar een definitie en naar belangrijke criteria voor het zijn van een professie.

Voor het kwalificeren voor een professie is volgens Greenwood (1957) maatschappelijke steun noodzakelijk, die alleen verkregen kan worden als de maatschappij de beroepsgroep hiervoor kwalificeert. Loopbaanadvisering zou deze maatschappelijke steun betrekkelijk snel kunnen verwerven als erkend wordt dat de

\footnotetext{
${ }^{3} \mathrm{VNO}-\mathrm{NCW}$ is de fusienaam voor Verbond van Nederlandse Ondernemingen en het Nederlands Christelijke Werkgeversverbond.
} 
nieuwe beroepsgroep ook een belangrijke maatschappelijke bijdrage heeft, doordat zij mensen die weinig of geen zicht hebben op een goede toekomst door begeleiding weer een nieuw arbeidsperspectief kan geven.

Een ander criterium voor een 'professie' in de zienswijze van Greenwood (1957) is wetenschappelijke steun door onderzoek en onderwijs. Sommigen (zoals Schiersmann et al., 2016) vinden dat leden van beroepsgroepen die zich als een professie profileren, zelf minimaal een masters titel moeten kunnen tonen. Anderen, waaronder De Sonnaville (2005), vinden dat niet noodzakelijk.

Een derde belangrijk criterium voor het kwalificeren als een professie is legitimatie door de overheid. Zonder jurisdictie van de overheid, die de beroepsgroep ook de formele basis geeft voor classificatie, is de ontwikkeling tot een professie niet goed mogelijk. Dit proefschrift wil bijdragen om, door aan een groter publiek meer inzicht te geven over de status van de ontwikkeling van loopbaanadvisering, de mogelijkheid voor een formele basis te vergroten voor de ontwikkeling naar een professie.

\subsubsection{Kernoragen}

Om inzicht te verkrijgen in de mate waarin loopbaanadvisering zich tot nu toe heeft ontwikkeld tot een professie, worden in dit hoofdstuk drie kernvragen opgesteld. Ten eerste zal getracht worden de mate van ontwikkeling van loopbaanadvisering tot een professie te toetsen aan de hand van een aantal criteria. De eerste kernvraag luidt derhalve als volgt:

Kernvraag 1: In hoeverre heeft loopbaanadvisering zich ontwikkeld tot een professie? 
Het antwoord op de vraag in hoeverre loopbaanadvisering zich heeft ontwikkeld tot een professie wordt versterkt indien een referentiekader geschetst kan worden. Hiertoe zou onderzocht moeten worden in hoeverre andere beroepsgroepen, die in de volksmond een professie genoemd worden, zich ontwikkeld hebben tot een professie. In dit hoofdstuk worden de volgende beroepsgroepen onderzocht: geneeskunde, tandheelkunde, advocatuur, notariaat, accountancy, apotheek, geestelijkheid en wetenschap. De tweede kernvraag luidt derhalve als volgt:

Kernvraag 2: In hoeverre hebben andere beroepsgroepen, die in de volksmond een professie genoemd worden, zich ontwikkeld tot een professie?

In aansluiting op deze vraag dient onderzocht te worden hoe loopbaanadvisering zich verhoudt tot andere beroepsgroepen, die zich reeds hebben ontwikkeld tot een professie. Zodoende kan een indruk verkregen worden van de mogelijke verschillen tussen de beroepsgroep loopbaanadvisering en een aantal andere vakgebieden die een professie genoemd worden. De derde vraag luidt derhalve als volgt:

Kernvraag 3: Bestaan er verschillen tussen loopbaanadvisering en andere beroepsgroepen, die een professie worden genoemd?

\subsubsection{Opbouw van het hoofdstuk}

De verdere opbouw van dit hoofdstuk is als volgt: In paragraaf 3.2 wordt een literatuuroverzicht gegeven, waarbij onderzocht wordt wat de wetenschap onder een 'professie' verstaat. In paragraaf 3.3 zal de methodiek gepresenteerd worden, 
waarbij eerst de opzet van het onderzoek naar het concept professie zal worden aangegeven. Daarna zal de steekproef worden toegelicht en tenslotte zal worden ingegaan op de wijze van meting. In paragraaf 3.4 zullen de onderzoeksresultaten uitgewerkt worden, waarna in paragraaf 3.5 de conclusies besproken worden, die zullen leiden tot discussie.

\subsection{Literatuuronderzoek}

Het begrip 'professie' is terug te voeren tot de gildes (Weggeman, 1997), waarbij het gilde de gehele keten vanaf inkoop via de productie naar de verkoop en de opleiding beheerste. Het gilde zorgde voor een waarborg van kwaliteit en voor bescherming tegen ongewenste concurrenten. Onder invloed van de arbeidsverdeling, na de industriële revolutie, ontstaan er in de 19de eeuw georganiseerde verbanden, waar beroepsgroepen, die een 'professie' genoemd worden, zoals geestelijken, hoogleraren, artsen, advocaten, notarissen en accountants, een vaste plaats krijgen.

In de literatuur komt men een veelheid van sociaalwetenschappelijke studies tegen op dit gebied. Allereerst dient inzicht verkregen te worden in hoe de wetenschap een professie definieert. Rond het begrip professie is in de wetenschap veel discussie gevoerd (Burrage, Jarausch, \& Siegrist, 1990). In eerste instantie werd gezocht naar een bruikbare definitie.

De Sonnaville (2005) liet zien hoe moeilijk de begrippen professie, professional en professionalisering te onderscheiden zijn, alhoewel ze in de dagelijkse praktijk frequent naast elkaar gebruikt worden. De Sonnaville geeft het voorbeeld van een sportman of -vrouw, die in een bepaalde sport professional is, ter onderscheiding van een amateur. Dit wil niet zeggen dat diegene ook op een professionele manier zijn of haar sport bedrijft. 
De socioloog Van Doorn (1966) typeert een professie als een beroep dat gericht is op sociale waarden en waarvan de uitoefening in beginsel de behartiging van een 'hoog goed' betreft. Een professie wordt door hem van een beroep onderscheiden door verschil te maken tussen 'denken' in plaats van 'doen'. In de Angelsaksische literatuur wordt het verschil tussen een professie en een beroep duidelijk gemaakt door de woorden 'profession' en 'occupation', waardoor het verschil in 'denken' en 'doen' duidelijker dan in de Nederlandse taal tot uiting komt.

Ook Freidson (2001) doet pogingen om een sluitende definitie te geven, maar een echt sluitende definitie blijft moeilijk te geven. Burrage geeft hieraan een goede draai, door te stellen dat een professie een "troublesome" concept is, waardoor het formuleren van criteria te prefereren valt. Hiermede wordt door de wetenschap een professie niet gedefinieerd, maar wel zorgvuldig beschreven.

Zo heeft de Amerikaanse socioloog Freidson (2001) ook een belangrijke publicatie over 'professioneel handelen' geschreven, als een systematische methode om werk te organiseren. Freidson onderscheidt daarbij drie soorten beroepsgroepen: 1) beroepsgroepen gericht op de markt; 2) beroepsgroepen gericht op het bureaucratisch bestel en 3) beroepsgroepen gericht op professioneel handelen. Hij laat zien dat alle drie soorten beroepsgroepen een eigen logica hebben, gericht op verschillende soorten kennis, organisatie, opleiding en ideologie.

Volgens Freidson (2001) hebben de beroepsgroepen gericht op de markt de koopkrachtige klant als uitgangspunt. Hierdoor is er keuzevrijheid en worden de prijzen door concurrentie laag gehouden. In deze beroepsgroepen zijn de consumenten leidend. Bij beroepsgroepen gericht op het bureaucratische bestel staat volgens Freidson de rechtsgelijkheid en daarmee de zorgvuldigheid en de voorspelbaarheid centraal. In een bureaucratisch bestel zijn er geen uitzonderingen. Als een iemand een voordeel ontvangt, ontvangt iedereen hetzelfde voordeel. Door deze 
zorgvuldigheid werkt het bureaucratische bestel vaak traag. In deze beroepsgroepen bepalen de managers de werkwijze.

Ten slotte is bij beroepsgroepen gericht op professioneel handelen de kern van het professioneel handelen 'de seculiere roeping'. Onder professioneel handelen verstaat Freidson een arbeidsstructuur die kwalitatief beheerst wordt door de beroepsgroep zelf, en niet door de markt (de klant) of door een bureaucratische organisatie. Voor een professional betekent service primair dienstbaarheid aan waarden die uitstijgen boven het bedienen van de markt of de gelijkheid van het bureaucratische bestel. De dienstbaarheid komt voort uit de eigen visie op de situatie van de cliënt, gebaseerd op opleiding en ervaring met vergelijkbare gevallen.

Centraal staat wat de cliënt nodig heeft en niet wat de cliënt bereid is te betalen. Het streven van een professional is om steeds beter te worden in het eigen vak door 'life long learning' en om bij te dragen aan de ontwikkeling en verspreiding van de collectief beschikbare kennis, waardoor de beroepsuitoefening verdiept en ver-beterd kan worden. In de professionele beroepsgroepen bepalen de gespecialiseerde professionals zelf hoe zij hun werk willen inrichten.

Freidson (2001) laat zien dat de drie soorten beroepsgroepen allen een eigen logica hebben, gericht op verschillende soorten kennis, organisatie, opleiding en ideologie. Hij noemt de beroepsgroepen gericht op professioneel handelen 'the third logic'. Deze 'derde logica' heeft betrekking op de wijze van werk, gericht op professioneel handelen en dienstbaarheid. Freidson (2001) maakt daarnaast onderscheid tussen ambacht, beroep en professie. Hij zegt dat de ontwikkeling van het ambacht naar een professie betekent dat de beoefenaren van de professie over substantiële kennis moeten beschikken waar 'meesterschap' uit blijkt.

Zowel Abbott (1988) als MacDonald (1995) beschrijven twee andere richtingen voor onderzoek naar professies en professionalisering. Ten eerste 
noemen zij de taxonomische ${ }^{4}$ of statische lijn: dit behelst het geven van definities en kenmerken, met als doel onderscheid te maken tussen beroep en professie door middel van classificatie. Deze statische benadering werd al in de jaren '30 - '50 van de vorige eeuw aangehangen, met de medische wereld als lichtend voorbeeld van een professie (Stevens, 2014). Dit werd ook wel de 'conceptbenadering' genoemd. Deze benadering werd door vele auteurs inzake een professie en professionaliseren ondersteund (bijvoorbeeld: Greenwood, 1957; Johnson, 1972; Noble, 1977; Parsons, 1954; Schuyt, Louwerse, \& Schuyt-Lucassen, 1988; Van der Kroft, 1981).

Ten tweede noemen Abbott en MacDonald de historische of dynamische lijn. Deze benadering laat zien hoe een beroep zich geleidelijk kan ontwikkelen tot een professie. Een professie is in deze benadering een proces van beroepsvorming of een professionaliseringsproject. Dit wordt ook wel de 'procesbenadering' genoemd. Ook deze benadering wordt door vele onderzoekers van professies en professionalisering ondersteund (zoals bijvoorbeeld: Abbott, 1988; Burrage, Jarausch \& Siegrist, 1990; Larson, 1977; Maas, 1999; MacDonald, 1995; en Stevens, 2014).

Naar het oordeel van de auteur van dit proefschrift kan een professie het beste op basis van een combinatie van statische en dynamische elementen beschreven worden. In lijn met Abbott en Mac Donald werden door Greenwood (1957) en Maas (1999) bruikbare criteria opgesteld voor de beroepsgroepen gericht op professioneel handelen: Greenwood (1957) vanuit de extern gerichte, taxonomische conceptbenadering en Maas (1999) vanuit de intern gerichte, historische procesbenadering. Conceptbenadering voor professioneel handelen

\footnotetext{
${ }^{4}$ Een taxonomie is een structuur die het mogelijk maakt om content over personen, organisaties, gebeurtenissen en dingen te clusteren in (hiërarchische) groepen zodat ze gemakkelijk te identificeren, te bestuderen en terug te vinden zijn.
} 
In de conceptbenadering onderscheidt de professie zich van reguliere beroepsgroepen door bepaalde structurele eigenschappen, zoals het hebben van een missie en een visie, en bovendien doordat de beroepsgroep als professie een vitale functie in de maatschappij vervult. In de jaren dertig van de vorige eeuw werd een professie via de conceptbenadering gedefinieerd als een separate autonome doelgroep, waar vervolgens bepaalde eigenschappen aan werden toegevoegd (CarrSaunders \& Wilson, 1933; Parsons, 1954), zoals maatschappelijke steun en erkenning. De conceptbenadering was daarmee extern gericht. Er werd gedacht in min of meer vaste patronen van ontwikkeling tot een professie.

Klassieke voorbeelden van een professie zijn: de priester (goed en kwaad), de hoogleraar (waar en onwaar), de arts (ziek en gezond), de advocaat (recht en onrecht), de notaris (wettelijk en onwettelijk) en de accountant (correct en incorrect). $\mathrm{Al}$ deze professies dienen een maatschappelijk belang. Het concept professie wijst daarbij naar organisaties van beroepsbeoefenaren zoals de kerk, de universiteit en de medische wereld. Met name is er een onderscheid tussen 'denken en doen'5.

Ook wordt een professie gedefinieerd als een beroepsgroep met een aantal specifieke kenmerken, door bijvoorbeeld Larson (1977). Hij noemt de volgende vier specifieke kenmerken:

1) kennis en bekwaamheid;

2) generalistisch ingesteld;

3) bevrediging van een vitale behoefte;

4) een onbaatzuchtige houding.

\footnotetext{
${ }^{5}$ In het Engels is er voor het woord beroep een onderscheid tussen 'profession' (denken) en 'occupation' (doen).
} 
Greenwood (1957) stelde als één van de aanhangers van de zogenaamde conceptbenadering acht (statische) criteria op waaraan een beroepsgroep moet voldoen om een professie te zijn. Deze zijn:

1) een beroeps- en branchevereniging;

2) een missie en een visie;

3) een beroepscode en een beroepscommissie;

4) gecertificeerde opleidingen;

5) zelfregulering met sanctionering door de overheid;

6) wetenschappelijke steun (onderzoek en onderwijs);

7) maatschappelijke steun en erkenning;

8) een legitimatie door de overheid.

Er bestaat echter ook kritiek op de conceptbenadering. MacDonald (1995) geeft bijvoorbeeld aan dat zelfbescherming door een standaard aanpak en vaststaande beroepscodes één van de primaire redenen is voor de ontwikkeling van een regulier vakgebied naar een professie. Daarnaast is het hebben van (maatschappelijke) status een verzekering voor macht en inkomen. MacDonald constateert bovendien dat normen en waarden in de praktijk minder blijken voor te komen als reden voor de ontwikkeling naar een professie dan in de conceptbenadering aangenomen wordt. Voorts is er veelal geen aandacht voor de feitelijke ontwikkeling binnen de beroepsgroep en is er geen oog voor dynamische aspecten van de professionalisering.

Ook Abbott (1988) heeft op grond van zijn praktijkonderzoek kritiek op de conceptbenadering. Hij bestrijdt de conceptbenadering als uitgangspunt voor het begrip professie, vanwege enkele discutabele aannames van de conceptbenadering. Abbott merkt ten eerste op dat de conceptbenadering er ten onrechte vanuit gaat dat 
professies vaststaande entiteiten zijn, terwijl er volgens hem een grote variëteit van vormen bestaat en ze bovendien onderhevig zijn aan allerlei ontwikkelingen. Een sterk regulerende, intern hechte professie is hiervan maar één voorbeeld. Daarbij ontwikkelt een professie zich volgens hem niet in isolement ten opzichte van andere professies; de ontwikkeling van een specifieke professie moet begrepen worden in relatie tot de ontwikkelingen bij andere aanpalende beroepsgroepen.

Ook is het feitelijke werk dat een beroepsgroep doet volgens Abbott belangrijker voor een professie dan de sociale structuur of de culturele claims, die beroepsbeoefenaren aan elkaar verbinden. Voorts zijn professies volgens hem geen homogene entiteiten bestaande uit individuele professionals, maar laten ze zich kenmerken door een grote mate van diversiteit en verschillen binnen dezelfde beroepsgroep. En ten slotte is professionaliseren een proces dat onderhavig is aan de factor tijd. Iedere professie kent zijn eigen historisch professionaliseringsproces. Abbott pleit daarom voor een meer interactionistische benadering om professies te bestuderen.

\section{Procesbenadering voor professioneel handelen}

De procesbenadering onderscheidt zich van de conceptbenadering door te benadrukken dat de ontwikkeling van een specifieke beroepsgroep naar een professie zich voltrekt via een organisch proces. Veel sociologen hebben inmiddels dan ook afstand genomen van het begrip professie als (statisch) ideaalmodel.

Zowel Abbott (1988) als MacDonald (1995) zijn aanhangers van de procesbenadering. Zij leggen de nadruk op de ontwikkeling van de beroepsgroep als een proces van binnenuit. Zij richten zich op vragen als wat professies doen om ervoor te zorgen dat zij hun speciale positie niet verliezen. Er wordt ook veel meer dan bij de conceptbenadering gekeken naar de verschillende actoren die een actieve 
rol spelen in de ontwikkeling van het vakgebied, zoals de overheid, de universiteit en andere stakeholders.

Een volgende invloedrijke auteur binnen de procesbenadering is Freidson (1970; 1983): vooral door hem is het denken over een professie veranderd. Freidson geeft aan dat professionals de potentie hebben om hun eigen werkelijkheid te definiëren, zowel binnen het vakgebied als daarbuiten, waardoor een claim wordt gelegd op de eigen waarheid (universele validiteit). De standaarden en ook de competenties die professionals moeten bezitten om toegelaten te worden tot de professie liggen daarmee volgens Freidson, tenminste voor de korte termijn, vast.

Larson (1977) vat het proces van professionaliseren op als het monopoliseren van kennis en status om sociale prestige te bereiken, wat leidt tot het beheersen van de betreffende deelmarkt. Hij onderscheidt drie dimensies waarop beroepsgroepen zich onderscheiden. Ten eerste bestaan er volgens Larson beroepsgroepen die 'social disclosure' nastreven op basis van economische motieven (geld verdienen); ten tweede zijn er beroepsgroepen die sociale motieven nastreven (ergens bij horen) en ten derde zijn er beroepsgroepen die macht nastreven. In alle drie dimensies gaat het om het zich kunnen afschermen.

Larson noemt in dit kader twee aspecten waarop de ontwikkeling naar professioneel handelen gebaseerd is: 'wetenschappelijke kennis' enerzijds en 'de vrije markt' anderzijds. Het geeft de mogelijkheid tot (ruime) beloning op basis van schaarste, als de monopolist tevens kan beschikken over voldoende kennis en sociale status. De bezitters van deze kennis kunnen daarmee de markt beheersen en overgaan tot standaardisering van en controle op de verspreiding van de kennis, waardoor zij in een positie komen waarin zij kunnen onderhandelen met de overheid over regulering. Volgens Larson kan de beroepsgroep daardoor de toegang tot de professionele kennis alsook de toegang tot de markt reguleren. 
Vanwege deze nadruk op de ontwikkeling van vakgebieden naar een professie in de procesbenadering zien Burrage et al. (1990) er dan ook van af om de term professie te definiëren. Ook zij zijn er, evenals hun collegae uit de conceptbenadering, toe overgegaan om criteria op te stellen waarmee het begrip professie het best omschreven werd. Zo gebruiken zij de acht criteria van Kocka (1988), die een professie omschrijft als:

1) een professie werkt veelal niet ambachtelijk;

2) de beroepsgroep werkt fulltime;

3) de beroepsgroep werkt veelal als specialisatie;

4) de beroepsgroep kent een beroepsopleiding, met een door de beroepsgroep erkend diploma en daarmee samenhangende titulatuur;

5) de beroepsgroep claimt een zeker monopolie voor de geleverde diensten en vraagt een vrijheid van handelen zonder controle van wie dan ook;

6) de beroepsgroep baseert zich op eigen specifieke competenties en eigen professionele ethische waarden en normen;

7) de beroepsgroep beroept zich op een speciale status in de maatschappij;

8) de beroepsgroep claimt ruime honorering voor de specifieke diensten en sociale waardering.

Een aantal auteurs, zoals Abbott (1988) en Burrage et al. (1990), maar ook Maas (1999), zien een professie als een verbijzondering van een beroepsgroep, waarbij deze meer gekwalificeerd wordt als een professie naarmate deze zich meer plaatst in het centrum van de maatschappelijke ordening. Daarnaast onderscheidt Maas (1999) een professie van een gewone beroepsgroep door acht meer intern gerichte dynamische criteria. Deze worden hierna opgesomd: 
1) een theoretisch gefundeerd kennisdomein;

2) het gezag wordt ontleend aan kennis;

3) een lang proces van scholing, training, en ervaring;

4) oplossing van problemen door altruïsme; altijd klaar om te helpen;

5) controle op kwaliteit door experts;

6) toetsing van competenties en toetsing wie het beroep mag uitoefenen;

7) zelfregulering gereguleerd door een beroepsvereniging, vastgelegd in een ethische (beroeps)code;

8) toezicht op naleving door middel van een tuchtcollege.

Maas is hiermee een typische aanhanger van de procesbenadering. De procesbenadering is, in tegenstelling tot de conceptbenadering, intern gericht, maar ook dynamisch van aard, door steeds gericht te zijn op de ontwikkeling van het vakgebied.

\section{Reflectie inzake de conceptbenadering en de procesbenadering in de literatuur}

Om te bepalen in hoeverre een beroepsgroep een professie genoemd kan worden, is het van belang te onderzoeken welke criteria er passend zijn voor beroepsgroepen die zich in de volksmond een professie noemen. Uit het bovenstaande literatuuronderzoek naar een professie bleek dat, nadat in eerste instantie getracht werd om een allesomvattende definitie te formuleren, men in de wetenschap tot de conclusie kwam dat het beschrijven van een professie door middel van criteria effectiever blijkt te zijn. Veel auteurs poogden criteria voor de mate van professie te formuleren. Een goed voorbeeld daarvan is Kocka (1990). Ook werd al vroeg door wetenschappers de conceptbenadering (bijvoorbeeld: Greenwood, 1957) en vervolgens de procesbenadering (bijvoorbeeld: Maas, 1999) 
gebruikt om een professie te beschrijven. In dit hoofdstuk zullen zowel de acht criteria van Greenwood (1957) voor de conceptbenadering als ook de acht criteria van Maas (1999) voor de procesbenadering worden ingezet voor het beantwoorden van de drie onderzoeksvragen. De acht criteria van Kocka worden niet voor het onderzoek gebruikt, omdat de criteria van Kocka en de andere criteria te veel overlapten en omdat de criteria van Kocka enigszins gedateerd waren. Dat laatste wijst er wel op dat de criteria die een professie onderbouwen steeds in beweging zijn, waardoor deze regelmatig in de tijd aangepast behoren te worden.

Larson (1977) richt zich op de ontwikkeling van specifieke beroepsgroepen en op de vraag wat professies doen om hun speciale positie in het leven van alledag af te dwingen en te behouden. Abbott (1988) focust in dit verband op werk in plaats van op instituties, zoals onderzoekers deden in het kader van de conceptbenadering. Abbott benadrukt dat een professie zich ontwikkelt door de interactie tussen de betrokken stakeholders. Abbott concentreert zich op drie aspecten die kenmerkend zijn voor professioneel werk, namelijk: diagnose, behandeling en toetsing, gekoppeld aan een systeem van kennis als basis van waaruit de professional werkt. Deze abstracte of academische kennis legitimeert als het ware het werk dat de professional doet.

Abbott (1988) geeft daarbij aan dat door duidelijk te maken wat de grondbeginselen en de waarden van een beroepsgroep zijn, de beroepsgroep een zekere jurisdictie verkrijgt. Door deze jurisdictie geeft het academische kennissysteem bijvoorbeeld aan dat er voor een professie drie specifieke taken zijn: het legitimeren van gehanteerde toegepaste kennis, het doen van research om de kennis verder te ontwikkelen en het geven van instructie om de kennis over te dragen. Abbott zegt hierover dat wanneer een beroepsgroep jurisdictie claimt, de beroepsgroep in feite algemene geldigheid aan de gemeenschap vraagt om 
exclusieve rechten om met deze specifieke kennis te mogen werken. Deze erkenning kan leiden tot een zekere vorm van monopolie voor de werkzaamheden die de beroepsgroep uitoefent.

Volgens Abbott (1988) is het essentieel voor een beroepsgroep om zelf te claimen dat de beroepsgroep een professie is, omdat zonder die claim de beroepsgroep nooit met succes de competitie aan kan gaan met andere beroepsgroepen om jurisdictie in de samenleving te verkrijgen. Daarbij gaat Abbott ervan uit dat hoe hechter een professie georganiseerd is, hoe effectiever een claim kan worden gelegd op jurisdictie in de samenleving. Bovendien geeft hij aan dat er in feite vijf actoren zijn die bepalen op welke wijze een specifieke beroepsgroep zich ontwikkelt: de professional zelf, de cliënt, de overheid, de universiteit en de aanpalende beroepssectoren.

Burrage et al. (1990) vullen dit aan door de stelling dat praktiserende professionals het startpunt en de sleutelfiguren zijn van de professionele ontwikkeling van hun beroepsgroep op weg naar een professie. Door deze zelfsturing wordt dan meestal in overleg met de beroepsvereniging bepaald wie wel en wie niet toegang krijgt tot de beroepsgroep. Burrage et al. (1990) zeggen dat op deze manier de belangen van de professie het best gediend zijn. Dit wordt vervolgens gewaarborgd door beroepsopleidingen, die onder controle staan van de professie zelf.

De beroepsopleidingen zijn tevens sociale netwerken voor de eigen beroepsgroep. Buitenstaanders hebben wel invloed op de ontwikkeling van de beroepsgroep, maar het zijn de professionals zelf die de 'Body of Knowledge and Skills' bepalen en tevens bepalen wat er onder professioneel handelen verstaan wordt. 
Burrage et al. (1990) zeggen dat de hechtheid van de beroepsgroep ervoor zorgt dat de professionals zelf hun eigen gedrag definiëren en ook de eigen gedragscode samenstellen. Daarnaast zeggen zij dat de beroepsgroep al snel te maken gaat krijgen met de maatschappij als geheel en daarbij met name met de overheid, de universiteit en de consument. Dat wordt door hen als volgt uitgewerkt.

De overheid: Zonder steun van de overheid kunnen professies en geïnstitutionaliseerde beroepsgroepen volgens Burrage et al. (1990) niet bestaan. In het algemeen geeft de overheid de beroepsgroep uiteindelijk het mandaat om het specifieke werk op officiële basis te mogen uitoefenen. De overheid ondersteunt de beroepsgroep ook om de jurisdictie te handhaven.

Tevens beschermt de overheid de consumenten ten aanzien van de beroepsgroep en legitimeert de verbinding tussen het volgen van de opleiding en het geaccepteerd worden binnen de beroepsgroep. Ook hebben bepaalde beroepsgroepen een wettelijke erkenning (zoals bijvoorbeeld medische professies). De overheid beïnvloedt dus sterk hoeveel macht, status en prestige een beroepsgroep heeft. In Nederland is het huidige beleid van de overheid overigens meer gericht op een niet-reguleringsbeleid, waardoor het marktmechanisme meer invloed heeft dan in landen met een meer centralistisch beleid.

De universiteit: Burrage et al. (1990) zijn van mening dat beroepsgroepen die zich een professie kunnen noemen een universitaire opleiding dienen te hebben. Hier zijn andere auteurs (bijvoorbeeld Collins, 1979, en Parsons, 1954) het niet mee eens. Er is ook een spanningsveld tussen 'praktijk' professionals en 'academische' professionals. 'Praktijk' professionals willen liever de bestaande 'Body of Knowledge' behouden; 'academische' professionals willen deze juist verder ontwikkelen. 
De cliënt: Burrage et al. (1990) geven aan dat de rol van de klant, patiënt of opdrachtgever zeer verschillend kan zijn. Het verschil in naamgeving maakt dat al duidelijk. Zij wijzen er ook op dat de contractverschillen, zoals een inspanningsverplichting versus een resultaatverplichting, per beroepsgroep ook zeer verschillend zijn. Bovendien kan de betaling per beroepsgroep een verschillende rol spelen. Bij de arts speelt betaling door de patiënt nauwelijks een rol; bij een advocaat of notaris des te meer. Ook tussen een consultant en een opdrachtgever speelt de betaling een grote rol.

Maister (1993) wijst op een ander onderscheid: een professionele mentaliteit. Hij wijst erop dat in de conceptbenadering voor professies en professionals met name verwezen wordt naar status, prestaties inzake opleiding, autonomie en het recht om zonder leiding het beroep uit te kunnen oefenen. Maar dat er in de procesbenadering juist behoefte is om de cliënt te willen bedienen; een professionele attitude dus, waarbij de adviseur niet primair uit is op het verdienen van geld ${ }^{6}$. De procesbenadering van een professie (professionalisering) heeft volgens Maister (1993) een meer interactionistische (tussen de beroepsgroep, klant, overheid en universiteit) en dynamische benadering.

Burrage et al. (1990) merken echter op dat ook de procesbenadering er niet aan ontkomt om het begrip professie te omschrijven. Het begrip professionaliseren is veel gemakkelijker te omschrijven, namelijk als het unieke dynamische proces dat een beroepsgroep zelf creëert of doormaakt.

\footnotetext{
${ }^{6}$ Een voorbeeld van deze 'professionele attitude' is Van Ede E Partners, die jarenlang cliënten die zich tot hun gedachtegoed aangetrokken voelden, maar niet in staat waren het honorarium te betalen, te begeleiden tegen betaling van 'een fles sherry' in de verwachting dat de cliënt in betere tijden het honorarium alsnog op vrijwillige basis zou voldoen. De partners hadden tevens onderling afgesproken dat zij een derde van hun inkomen zouden inleveren om de begeleiding van deze cliënten te financieren.
} 
Het uiteindelijke doel - de professie - is volgens hen echter veel lastiger te omschrijven, omdat dit een statische situatie aangeeft, in plaats van een dynamisch einddoel. Ook ontwikkelt een professie zich continu, maar krijgt het een legitieme (statische) status door het zelf definiëren van een 'Body of Knowledge and Skills', alsmede door het zelf hebben van een beroepsvereniging en door het zelf opstellen van een gedragscode.

De Sonnaville (2005) zegt hierover dat door de benadering van Burrage et al. (1990) de conceptbenadering weer om de hoek komt kijken. Echter, de conceptbenadering heeft het bezwaar dat de ontwikkeling van een beroepsgroep niet kan worden vergeleken met andere beroepsgroepen, vanwege het ontbreken van de dynamische ontwikkeling.

\section{Professie: een troublesome concept}

Het bovenstaande literatuuroverzicht laat zien dat het vinden van één aanduiding voor een professie een moeilijke opgave is. Met name omdat duidelijk werd dat een statisch einddoel voor een professie in een dynamische wereld niet mogelijk is. Burrage et al. (1990) noemen een professie daarom een "troublesome concept". Ook De Sonnaville (2005) kwam tot de conclusie dat er op de conceptbenadering van een professie kritiek bestaat, maar ook dat de conceptbenadering een aantal goed gedefinieerde kenmerken van een professie gebruikte, waarmee onderzocht kan worden op welke wijze een beroepsgroep zich tot een professie kan ontwikkelen. 


\subsection{Methodiek}

\subsubsection{Design}

In dit hoofdstuk zal verslag worden gedaan van een kleinschalig exploratief survey-onderzoek. Het onderzoek ${ }^{7}$ betrof het uitzetten van een vragenlijst onder acht professionele experts ${ }^{8}$ van beroepsgroepen, die alle acht in de 'volksmond' een professie worden genoemd. Deze groep werd aangevuld door drie loopbaanadvies experts. Aan de in totaal elf experts werd gevraagd om een oordeel te geven over de eigen professie vanuit het eigen beroepsperspectief en zodoende aan te geven in welke mate zij hun eigen vakgebied als een professie beschouwen. Op deze wijze kon een vergelijking gemaakt worden tussen loopbaanadvisering en de acht andere beroepsgroepen die reeds een professie genoemd worden.

\subsubsection{Expertpanel}

Het panel bestond uit elf professionele experts uit diverse vakgebieden. Acht van de elf experts zijn of waren werkzaam in een vakgebied dat in de volksmond een professie wordt genoemd, te weten: arts, tandarts, advocaat, accountant, notaris, apotheker, dominee en hoogleraar. Zij hebben allen een wo-opleiding ${ }^{9}$ en vele jaren werkervaring. Naast hun specialisatie hebben zij daardoor allen een brede oriëntatie op het eigen vakgebied. Als hoogleraar, partner of vennoot bij op hun gebied leidende Nederlandse organisaties zijn zij allen ofwel nog werkzaam in hun

\footnotetext{
${ }^{7}$ Een onderzoek op deze geringe schaal kan vanzelfsprekend geen goed beeld geven van de mate waarin een vakgebied werkelijk een professie is; daarvoor is een veel grotere steekproef nodig. Dit onderzoek is dan ook alleen uitgevoerd met de intentie een indruk te verkrijgen van de mate waarin diverse vakgebieden beschouwd worden als een professie.

${ }^{8}$ De auteur van dit proefschrift geeft met 'professionele experts' de acht experts aan die allen een expertise hebben die een professie genoemd wordt.

${ }^{9}$ Vier van de acht professionele experts waren ook gepromoveerd in hun vakgebied; drie zijn tevens hoogleraar.
} 
vakgebied, ofwel recent gepensioneerden. De acht experts die de andere beroepsgroepen vertegenwoordigen zijn op één na mannen. De andere drie van de elf experts (inclusief de auteur van dit proefschrift) waren of zijn werkzaam in het vakgebied loopbaanadvisering. De drie loopbaanexperts waren als voorzitter, directeur en mentor verbonden aan CMI. ${ }^{10}$

\subsubsection{Meetinstrumenten}

Aan alle 11 experts zijn 16 criteria voorgelegd, waarbij de exacte vraag luidde: "Geef achter ieder criterium aan in hoeverre je denkt dat jouw eigen beroepsgroep als geheel vindt dat de beroepsgroep aan het betreffende criterium voldoet door middel van een cijfer, waarbij 1 = laag en 5 = hoog." De vraag ging dus niet zozeer over hoe de betreffende experts persoonlijk naar de criteria kijken, maar op welke manier volgens de expert de beroepsgroep als geheel naar de in paragraaf 3.2 opgesomde acht criteria van Greenwood (1957) en acht criteria van Maas (1999) kijkt.

\subsection{Resultaten}

De resultaten van het onderzoek zullen aan de hand van de in paragraaf 3.1 geformuleerde kernvragen worden besproken.

Kernvraag 1 luidde: In hoeverre heeft loopbaanadvisering zich ontwikkeld tot een professie? Om de mate waarin loopbaanadvisering een professie is exploratief te onderzoeken, werden de gemiddelden berekend van de scores die de drie experts aan de criteria van Greenwood (1957) en van Maas (1999) hadden gegeven.

\footnotetext{
${ }^{10}$ De vrouwelijke directeur, evenals de auteur van dit proefschrift, waren eerder werkzaam bij Van Ede E Partners. Zij hebben inmiddels beiden afscheid genomen van CMI om met pensioen te gaan. De mentor van CMI werkte als ondernemer in loopbaanadvisering. Hij volgde de auteur van dit proefschrift op als voorzitter van de branchevereniging, die in die tijd nog NOBOL heette.
} 
Criteria van Greenwood: zoals Tabel 3.1 aangeeft, beoordeelden de drie experts het vakgebied loopbaanadvisering op basis van de criteria van Greenwood (1957) met een hoge gemiddelde uitkomst van $M=4,04(S D=0,55)$. De criteria 'een beroepsgroep en een branchevereniging', alsmede 'een missie en visie' en 'een beroepscode en een beroepscommissie' werden alle drie met het hoogste cijfer (een 5 op een vijfpuntsschaal) beoordeeld. Voor alle drie de criteria geldt dat deze criteria in het vakgebied loopbaanadvisering gebruikt worden en ook naar behoren functioneren. 'Maatschappelijke steun en erkenning', werd naast 'wetenschappelijke steun' gemiddeld onder de 4 beoordeeld, met respectievelijk $M=3,33$ en $M=3,67$. Voorts valt op dat voor loopbaanadvisering slechts één criterium gemiddeld onder 3 scoort, namelijk 'zelfregulering, met sanctionering via de overheid' met $M=1,67$.

Criteria van Maas: Tabel 3.2 laat zien in welke mate de drie experts loopbaanadvisering als een professie beoordeelden aan de hand van de criteria van Maas (1999). De gemiddelde uitkomst op basis van de criteria van Maas is $M=3,75$ ( $S D=$ 0,36). Loopbaanadvisering kreeg van de drie experts voor de criteria 'zelfregulering via een ethische code door de beroepsvereniging' en 'toezicht op naleving door middel van een tuchtcollege' de hoogste beoordeling: een 5 op een vijfpuntsschaal. Beide criteria worden gebruikt en functioneren naar behoren.

Opmerkelijk is dat voor loopbaanadvisering het criterium 'zelfregulering' bij Maas de hoogste beoordeling (5) krijgt, terwijl de beoordeling bij Greenwood waarbij ook sprake moet zijn van sanctionering via de overheid - juist als laagste beoordeeld werd $(M=1,67)$. Een lang proces van scholing wordt gemiddeld beoordeeld op $M=2,33$. De Body of Knowledge and Skills, als een theoretisch gefundeerd kennisdomein, wordt op $M=4,33$ beoordeeld. De andere criteria worden tussen de 3 en 4 beoordeeld. 
Tabel 3.1

Uitkomsten en toelichting van loopbaanadvisering o.b.v. de acht criteria van Greenwood (conceptbenadering).

\begin{tabular}{|c|c|c|c|c|}
\hline Nr. & Criterium & $\begin{array}{l}\text { Toelichting criteria inzake } \\
\text { loopbaanadvisering }\end{array}$ & $M$ & $S D$ \\
\hline 1. & $\begin{array}{l}\text { Een beroeps- en } \\
\text { een branchevereniging }\end{array}$ & $\begin{array}{l}\text { Zijn aanwezig en } \\
\text { functioneren }\end{array}$ & 5,00 & 0 \\
\hline 2. & Een missie en een visie & $\begin{array}{l}\text { Zijn geformuleerd en } \\
\text { functioneren }\end{array}$ & 5,00 & 0 \\
\hline 3. & $\begin{array}{l}\text { Een beroepscode en } \\
\text { een beroepscommissie }\end{array}$ & $\begin{array}{l}\text { Zijn aanwezig en } \\
\text { functioneren }\end{array}$ & 5,00 & 0 \\
\hline 4. & Gecertificeerde opleidingen & $\begin{array}{l}\text { Functioneren of zijn in de } \\
\text { opstart }\end{array}$ & 4,33 & 0,58 \\
\hline 5. & $\begin{array}{l}\text { Zelfregulering met } \\
\text { sanctionering via de } \\
\text { overheid }\end{array}$ & Is opgestart door OVAL & 1,67 & 0,58 \\
\hline 6. & $\begin{array}{l}\text { Wetenschappelijke steun } \\
\text { (onderzoek en onderwijs) }\end{array}$ & $\begin{array}{l}\text { Komt op gang via Open } \\
\text { Universiteit }\end{array}$ & 3,33 & 1,53 \\
\hline 7. & $\begin{array}{l}\text { Maatschappelijke steun en } \\
\text { erkenning }\end{array}$ & $\begin{array}{l}\text { Erkenning is redelijk, maar } \\
\text { zeker nog verbeterbaar }\end{array}$ & 3,67 & 0,58 \\
\hline 8. & Legitimatie door de overheid & $\begin{array}{l}\text { Overheid steunt beroeps- } \\
\text { groep inzake certificering }\end{array}$ & 4,33 & 1,15 \\
\hline \multicolumn{3}{|c|}{ Gemiddelde score voor de acht criteria } & 4,04 & 0,55 \\
\hline
\end{tabular}


Resumerend: als gevolg van de relatief lage beoordeling van loopbaanadvisering op basis van de criteria van Maas door de drie experts komt de gemiddelde beoordeling van de zestien criteria van Greenwood en Maas tezamen voor loopbaanadvisering eveneens onder de vier, namelijk: $M=3,90$ en $S D=0,46$. Wel werden voor loopbaanadvisering vijf van de zestien criteria gemiddeld met een vijf beoordeeld. Dit zijn: zelfregulering via ethische code (dynamisch), toezicht op naleving d.m.v. een tuchtcollege (dynamisch), een beroeps- en een branchevereniging (statisch); een missie en een visie (statisch); en een beroepscode en een beroepscommissie (statisch). Daarentegen werden zelfregulering met sanctionering door de overheid (met $M=1,67$ ) en een lang proces van scholing (met $M=2,33$ ) gemiddeld laag beoordeeld.

Kernvraag 2 luidde: In hoeverre hebben andere beroepsgroepen, die in de volksmond een professie genoemd worden, zich ontwikkeld tot een professie? Om te onderzoeken in hoeverre de andere beroepsgroepen zich tot een professie ontwikkeld hebben, werd gekeken naar de gemiddelde beoordelingen op basis van de zestien gehanteerde criteria. Tabel 3.3 laat zien dat op basis van de criteria van Greenwood de vakgebieden die een professie worden genoemd gemiddeld hoog beoordeeld werden, namelijk $M=4,38(S D=0,85)$. Het valt op dat zowel de beroepsgroep tandheelkunde als die van de apothekers beoordeeld werd met acht maal 5 , terwijl geneeskunde op $M=4,25$ beoordeeld werd. Het notariaat en de geestelijkheid werden gemiddeld lager dan 4 beoordeeld. Als onderzocht wordt in hoeverre er verschillen tussen de acht criteria zijn, dan valt op dat er maar één criterium gemiddeld $<4$ beoordeeld werd (maatschappelijke erkenning: $M=3,67$ ) en één criterium met gemiddeld 5 (gecertificeerde opleiding.) Sommige criteria werden slechts een fractie lager dan een 5 beoordeeld: 'wetenschappelijke steun' met $M=$ 4,88. Alle zes andere criteria werden boven 4 beoordeeld. 
Tabel 3.2

Uitkomsten van loopbaanadvisering o.b.v. de acht criteria van Maas (procesbenadering).

\begin{tabular}{cccc}
\hline Nr. Criterium & $\begin{array}{c}\text { Toelichting criteria inzake } \\
\text { loopbaanadvisering }\end{array}$ & $M$ & $S D$
\end{tabular}

1. Een theoretisch gefundeerd Een Body of Knowledge and

4,33

1,15

kennisdomein

Skills is aanwezig; plus een

beroepsprofiel voor

certificering

2. Gezag wordt ontleend aan Correct

$3,67 \quad 0,58$

kennis

3. Een lang proces van scholing Is in ontwikkeling; Open

$2,33 \quad 0,58$

Universiteit

4. Oplossing van problemen

Correct; maar niet altijd klaar

3,00

0

door altruïsme

om te helpen

5. Controle op kwaliteit door experts

Certificering op basis van

$3,67 \quad 0,58$

ISO 17024;

Controle door Raad voor

Accreditatie

6. Toetsing van competenties

Door CMI-toetsing; is echter

3,00

0

en toetsing wie het vak mag

nog niet algemeen aanvaard uitoefenen

als criterium voor

uitoefening van vak

7. Zelfregulering via ethische

Correct; door Noloc, OVAL

5,00

0

code door beroepsvereniging

en CMI

8. Toezicht op naleving d.m.v.

Tuchtcollege is aanwezig en

5,00

0 tuchtcollege werkt 
Tabel 3.3

Overzicht van de uitkomsten van de acht vakgebieden die in de volksmond een professie genoemd worden, op basis van de acht criteria voor de conceptbenadering van Greenwood voor een professie.

\begin{tabular}{|c|c|c|c|c|c|c|c|c|c|c|c|}
\hline Nr. & Criterium & 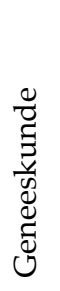 & 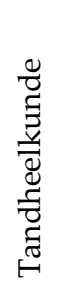 & 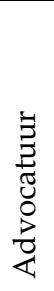 & 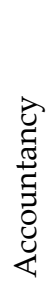 & 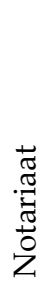 & 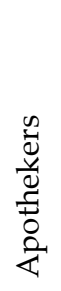 & 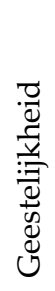 & 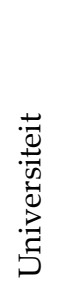 & $M$ & $S D$ \\
\hline 1. & $\begin{array}{l}\text { Beroepsgroep en } \\
\text { branchevereniging }\end{array}$ & 4 & 5 & 5 & 5 & 3 & 5 & 3 & 5 & 4,38 & 0,92 \\
\hline 2. & $\begin{array}{l}\text { Een missie en een } \\
\text { visie }\end{array}$ & 5 & 5 & 4 & 5 & 2 & 5 & 3 & 4 & 4,13 & 1,13 \\
\hline 3. & $\begin{array}{l}\text { Een beroepscode en } \\
\text { beroepscommissie }\end{array}$ & 5 & 5 & 4 & 5 & 3 & 5 & 5 & 5 & 4,63 & 0,74 \\
\hline 4. & $\begin{array}{l}\text { Gecertificeerde } \\
\text { opleidingen }\end{array}$ & 5 & 5 & 5 & 5 & 5 & 5 & 5 & 5 & 5,00 & 0,00 \\
\hline 5. & $\begin{array}{l}\text { Zelfregulering met } \\
\text { sanctionering via de } \\
\text { overheid }\end{array}$ & 5 & 5 & 4 & 3 & 4 & 5 & 1 & 5 & 4,00 & 1,41 \\
\hline 6. & $\begin{array}{l}\text { Wetenschappelijke } \\
\text { steun (onderzoek en } \\
\text { onderwijs) }\end{array}$ & 5 & 5 & 4 & 5 & 5 & 5 & 5 & 5 & 4,88 & 0,35 \\
\hline 7. & $\begin{array}{l}\text { Maatschappelijke } \\
\text { steun en erkenning }\end{array}$ & 3 & 5 & 5 & 3 & 3 & 5 & 2 & 4 & 3,75 & 1,16 \\
\hline 8. & $\begin{array}{l}\text { Legitimatie door de } \\
\text { overheid }\end{array}$ & 2 & 5 & 5 & 5 & 4 & 5 & 3 & 5 & 4,25 & 1,16 \\
\hline
\end{tabular}

$\begin{array}{lllllllllll}\text { Totaal gemiddelden } & 4,25 & 5,00 & 4,50 & 4,50 & 3,63 & 5,00 & 3,38 & 4,75 & 4,38 & 0,85\end{array}$

Noot. De beoordeling werd aangegeven op een vijfpuntsschaal $(1=$ laag en $5=$ hoog). 
De criteria van Maas: Een gedetailleerd overzicht van alle beoordeelde criteria is opgenomen in Tabel 3.4. Als gekeken wordt naar verschillen tussen de beroepsgroepen valt op dat geen enkele respondent zijn beroepsgroep voor alle criteria van Maas met een 5 beoordeelde. De beroepsgroep geneeskunde werd door de eigen vertegenwoordiger nog het hoogst beoordeeld met $M=4,88$. Geen enkele beroepsgroep werd op lager dan 4 beoordeeld.

Als gekeken wordt naar de verschillen tussen de criteria, dan is het merkwaardig dat altruïsme, klaar om te helpen, gemiddeld lager dan 4 beoordeeld werd $(M=3,63$ en $S D=0,74)$. Alleen de beroepsgroep geestelijkheid werd hierop met een 5 beoordeeld. Wel voldoen twee criteria voor alle beroepsgroepen bijna aan een totaal beoordeling met gemiddeld 5: een lang proces van scholing en toetsing, wie mag worden toegelaten, beiden met $M=4,75$.

Resumerend worden de acht beroepsgroepen die een professie genoemd worden in het algemeen door de respondenten in hoge mate beschouwd als een professie. Het valt op dat de acht beroepsgroepen gemiddeld dezelfde relatief hoge beoordeling gaven voor zowel de criteria van Greenwood als voor de criteria van Maas $(M=4,38)$.

In Tabel 3.5 worden de gezamenlijke gemiddelde uitkomsten van de criteria van Greenwood en Maas tezamen weergegeven. 
Tabel 3.4

Overzicht van de uitkomsten van acht criteria van Maas voor de procesbenadering voor een professie door acht beroepsgroepen die in de volksmond een professie genoemd worden.

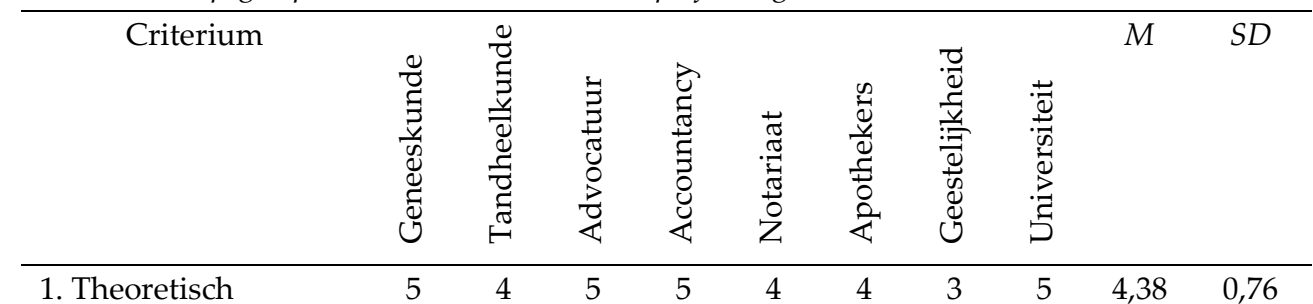

gefundeerd

kennisdomein

$\begin{array}{llllllllllll}\text { 2. Gezag ontleend aan } & 5 & 4 & 5 & 4 & 4 & 4 & 3 & 5 & 4,25 & 0,71\end{array}$ kennis

$\begin{array}{lllllllllll}\text { 3. Lang proces van } & 5 & 5 & 5 & 5 & 4 & 4 & 5 & 5 & 4,75 & 0,46\end{array}$

scholing, training,

ervaring

$\begin{array}{lllllllllll}\text { 4. Oplossing } & 4 & 4 & 4 & 3 & 3 & 3 & 5 & 3 & 3,63 & 0,74\end{array}$

problemen door

altruïsme

$\begin{array}{llllllllllll}\text { 5. Kwaliteitscontrole } & 5 & 5 & 4 & 4 & 4 & 4 & 2 & 5 & 4,13 & 0,99\end{array}$ door experts
6. Toetsing
$5 \quad 5$
$4 \quad 5 \quad 5$
5
$4,75 \quad 0,46$

competenties

$\begin{array}{llllllllllll}\text { 7. Zelfregulering door } & 5 & 5 & 4 & 5 & 4 & 5 & 4 & 5 & 4,63 & 0,52\end{array}$

de beroepsvereniging

via een ethische code
8. Toezicht op
$5 \quad 5$
$4 \quad 5$
$4 \quad 5 \quad 5 \quad 5$
$4,75 \quad 0,46$
naleving via
tuchtcollege

$\begin{array}{lllllllllll}\text { Totaal gemiddelden } & 4,88 & 4,63 & 4,38 & 4,50 & 4,00 & 4,13 & 4,00 & 4,63 & 4,38 & 0,65\end{array}$

Noot. De beoordeling werd aangegeven op een vijfpuntsschaal ( $1=$ laag en $5=$ hoog). 
Tabel 3.5

Overzicht van de uitkomsten van acht criteria van Greenwood en acht criteria van Maas voor een professie door acht beroepsgroepen die een professie genoemd worden.

\begin{tabular}{|c|c|c|c|c|c|c|c|c|c|c|}
\hline &  & 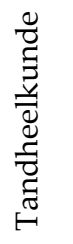 & 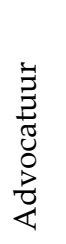 & 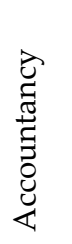 & 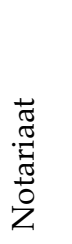 & 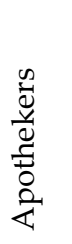 & 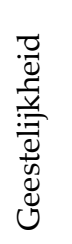 & 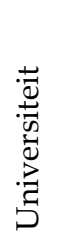 & $M$ & $S D$ \\
\hline Gemiddelden & 4,56 & 4,81 & 4,44 & 4,50 & 3,82 & 4,38 & 3,69 & 4,69 & 4,38 & 0,75 \\
\hline \multicolumn{11}{|l|}{16 criteria } \\
\hline Hiërarchie & 3 & 1 & 5 & 4 & 7 & 6 & 8 & 2 & & \\
\hline
\end{tabular}

Noot. De beoordeling werd aangegeven op een vijfpuntsschaal $(1=$ laag en $5=$ hoog).

Kernvraag 3 luidde: Bestaan er verschillen tussen loopbaanadvisering en andere beroepsgroepen, die een professie worden genoemd? Deze vraag werd beantwoord door loopbaanadvisering te vergelijken met de acht beroepsgroepen die een professie worden genoemd, op basis van acht criteria van Greenwood en acht criteria van Maas voor mate van professie.

Criteria van Greenwood: Tabel 3.6 laat zien dat loopbaanadvisering gemiddeld iets minder als een professie wordt gezien dan de andere acht beroepsgroepen. De gemiddelde beoordeling van loopbaanadvisering en van de andere acht beroepsgroepen tezamen bedroegen respectievelijk $M=4,04$ en $M=4,38$. De tabel laat zien dat er aanzienlijke verschillen bestaan in de beoordeling van twee van de criteria, namelijk: zelfregulering met sanctionering door de overheid $(M=1,67$ voor loopbaanadvisering, tegenover $M=4,00$ voor de andere beroepsgroepen); en wetenschappelijke steun ( $M=3,33$ voor loopbaanadvisering en $M=4,88$ voor de andere beroepsgroepen. Voor beide criteria is de ontwikkeling van de acht andere beroeps- 
groepen als professie veel verder gevorderd dan de ontwikkeling van loopbaanadvisering.

Opmerkelijk is ook dat vier criteria een hogere gemiddelde beoordeling laten zien voor loopbaanadvisering dan gemiddeld voor de acht andere beroepsgroepen samen. Dit zijn: beroepsvereniging en branchevereniging ( $M=5,00$ voor loopbaanadvisering en $M=4,38$ voor de andere beroepsgroepen); een missie en een visie ( $M$ = 5,00 voor loopbaanadvisering en $M=4,13$ voor de andere beroepsgroepen); een beroepscode en een beroepscommissie ( $M=5,00$ voor loopbaanadvisering en $M=$ 4,63 voor de andere beroepsgroepen) en legitimatie door de overheid ( $M=4,33$ voor loopbaanadvisering en $M=4,25$ voor de andere beroepsgroepen).

De criteria van Maas: Op basis van een t-toets blijkt dat er voor de criteria van Maas wel een significant verschil bestaat tussen loopbaanadvisering en de andere acht vakgebieden, namelijk $t(9)=3,31(p<0,01)$. Voorts laat Tabel 3.7 zien dat de loopbaanexperts de acht criteria van Maas een beoordeling van gemiddeld $M=3,75$ gaven. De andere acht beroepsgroepen werden op basis van de criteria van Maas beoordeeld met een gemiddelde score van $M=4,38$. Dit betekent dat loopbaanadvisering op basis van deze criteria gemiddeld minder als professie wordt beschouwd dan de acht andere beroepsgroepen tezamen. Bij twee van de criteria van Maas bestaan er aanzienlijke verschillen in beoordeling tussen loopbaanadvisering en de andere beroepsgroepen tezamen. Dat zijn: een lang proces van scholing, training en ervaring $(M=2,33$ voor loopbaanadvisering ten opzichte van $M=4,75$ voor de andere acht beroepsgroepen) en toetsing, wie het beroep mag uitoefenen $(M=3,00$ voor loopbaanadvisering ten opzichte van $M=4,75$ voor de andere acht beroepsgroepen). 
Tabel 3.6

Vergelijking van loopbaanadvisering met de andere acht beroepsgroepen, op basis van de acht criteria van Greenwood.

\begin{tabular}{|c|c|c|c|c|c|}
\hline \multirow[t]{2}{*}{ Nr. } & \multirow[t]{2}{*}{ Criterium } & \multicolumn{2}{|c|}{$\begin{array}{l}\text { Loopbaanadvisering } \\
\qquad(N=3)\end{array}$} & \multicolumn{2}{|c|}{$\begin{array}{c}\text { Andere } \\
\text { beroepsgroepen } \\
(N=8)\end{array}$} \\
\hline & & $M$ & $S D$ & $M$ & $S D$ \\
\hline 1. & $\begin{array}{l}\text { Beroepsvereniging en } \\
\text { branchevereniging }\end{array}$ & 5,00 & 0 & 4,38 & 0,92 \\
\hline 2. & Een missie en een visie & 5,00 & 0 & 4,13 & 1,13 \\
\hline 3. & $\begin{array}{l}\text { Een beroepscode en een } \\
\text { beroepscommissie }\end{array}$ & 5,00 & 0 & 4,63 & 0,74 \\
\hline 4. & Gecertificeerde opleidingen & 4,33 & 0,58 & 5,00 & 0 \\
\hline 5. & $\begin{array}{l}\text { Zelfregulering met } \\
\text { sanctionering door de overheid }\end{array}$ & 1,67 & 0,58 & 4,00 & 1,41 \\
\hline 6. & $\begin{array}{l}\text { Wetenschappelijke steun } \\
\text { (onderzoek en onderwijs) }\end{array}$ & 3,33 & 1,53 & 4,88 & 0,35 \\
\hline 7. & $\begin{array}{l}\text { Maatschappelijke steun en } \\
\text { erkenning }\end{array}$ & 3,67 & 0,58 & 3,75 & 1,16 \\
\hline 8. & Legitimatie door overheid & 4,33 & 0,55 & 4,25 & 0,85 \\
\hline $\mathrm{T}$ & al o.b.v. criteria Greenwc & 4,04 & 0,55 & 4,38 & 0,85 \\
\hline
\end{tabular}

Noot. De beoordeling werd aangegeven op een vijfpuntsschaal ( $1=$ laag en $5=$ hoog). 
Tabel 3.7

Vergelijk van de acht criteria van Maas door experts loopbaanadvisering en de acht professionele experts.

\begin{tabular}{|c|c|c|c|c|c|}
\hline \multirow[t]{2}{*}{$\mathrm{Nr}$. } & \multirow[t]{2}{*}{ Criterium } & \multicolumn{2}{|c|}{$\begin{array}{l}\text { Loopbaanadvisering } \\
\qquad(N=3)\end{array}$} & \multicolumn{2}{|c|}{$\begin{array}{c}\text { Andere } \\
\text { beroepsgroepen } \\
(N=8)\end{array}$} \\
\hline & & $\mathrm{M}$ & SD & $\mathrm{M}$ & SD \\
\hline 1. & $\begin{array}{l}\text { Een theoretisch gefundeerd } \\
\text { kennisdomein }\end{array}$ & 4,33 & 1,15 & 4,38 & 0,76 \\
\hline 2. & $\begin{array}{l}\text { Het gezag wordt ontleend aan } \\
\text { kennis }\end{array}$ & 3,67 & 0,58 & 4,25 & 0,71 \\
\hline 3. & $\begin{array}{l}\text { Een lang proces van scholing, } \\
\text { training en ervaring }\end{array}$ & 2,33 & 0,58 & 4,75 & 0,46 \\
\hline 4. & $\begin{array}{l}\text { Oplossing van problemen door } \\
\text { altruïsme; altijd klaar om te helpen }\end{array}$ & 3,00 & 0 & 3,63 & 0,74 \\
\hline 5. & $\begin{array}{l}\text { Controle op kwaliteit door experts: } \\
\text { voor de certificering }\end{array}$ & 3,67 & 0,58 & 4,13 & 0,99 \\
\hline & vanzelfsprekend & & & & \\
\hline 6. & $\begin{array}{l}\text { Toetsing van competenties en } \\
\text { toetsing wie het beroep mag } \\
\text { uitoefenen }\end{array}$ & 3,00 & 0 & 4,75 & 0,46 \\
\hline 7. & $\begin{array}{l}\text { Zelfregulering door een } \\
\text { beroepsvereniging vastgelegd in } \\
\text { een ethische (beroeps)code }\end{array}$ & 5,00 & 0 & 4,63 & 0,52 \\
\hline 8. & $\begin{array}{l}\text { Toezicht op naleving d.m.v. een } \\
\text { tuchtcollege }\end{array}$ & 5,00 & 0 & 4,63 & 0,52 \\
\hline & Totaal o.b.v. criteria Maas & 3,75 & 0,36 & 4,38 & 0,65 \\
\hline
\end{tabular}

Noot. De beoordeling werd aangegeven op een vijfpuntsschaal ( $1=$ laag en $5=$ hoog). 
Uit Tabel 3.8 blijkt dat loopbaanadvisering voor de zestien criteria tezamen gemiddeld werd beoordeeld met $M=3,90$; de andere beroepsgroepen gemiddeld met $M=4,38$. Derhalve blijkt dat loopbaanadvisering in voldoende mate kan worden beschouwd als op weg naar een professie, zij het dat de beroepsgroepen, die een professie genoemd worden, gemiddeld hoger scoren dan loopbaanadvisering. Zij worden hoger ${ }^{11}$ beoordeeld met het judicium goed $(>4.0)$. Tabel 3.8 geeft tevens aan dat de acht beroepsgroepen tezamen inzake de criteria voor zowel Greenwood als Maas eenzelfde gemiddelde uitkomst $(M=4,38)$ scoren.

Tabel 3.8

Vergelijk van de acht criteria van Greenwood en acht criteria van Maas door drie loopbaanadvisering experts en de acht experts, die allen een beroepsgroep vertegenwoordigen, die een professie genoemd wordt.

\begin{tabular}{|c|c|c|c|c|}
\hline \multirow[t]{2}{*}{ Auteur(s) } & \multicolumn{2}{|c|}{$\begin{array}{l}\text { Loopbaanadvisering } \\
\qquad(N=3)\end{array}$} & \multicolumn{2}{|c|}{$\begin{array}{l}\text { Andere beroepsgroepen } \\
\qquad(N=8)\end{array}$} \\
\hline & $M$ & $S D$ & $M$ & $S D$ \\
\hline Totaal o.b.v. criteria & 4,04 & 0,55 & 4,38 & 0,85 \\
\hline \multicolumn{5}{|l|}{ Greenwood } \\
\hline Totaal o.b.v. criteria Maas & 3,75 & 0,36 & 4,38 & 0,65 \\
\hline Totaal o.b.v. criteria & 3,90 & 0,46 & 4,38 & 0,75 \\
\hline Greenwood én Maas & & & & \\
\hline
\end{tabular}

Noot. De beoordeling werd aangegeven op een vijfpuntsschaal ( $1=$ laag en $5=$ hoog).

\footnotetext{
${ }^{11}$ Het blijkt dat loopbaanadvisering op vijf criteria hoger scoort dan het gemiddelde van de andere beroepsgroepen, terwijl de andere beroepsgroepen zevenmaal hoger scoren dan loopbaanadvisering. Viermaal is er sprake van een gelijke score.
} 


\subsection{Discussie}

\subsubsection{Bevindingen van het onderzoek}

Conceptbenadering: Als de acht criteria van Greenwood (1957) als uitgangspunt genomen worden om de beroepsgroep loopbaanadvisering te evalueren, dan zou de conclusie kunnen zijn dat aan alle genoemde externe criteria in voldoende mate wordt voldaan, waardoor van een professie gesproken kan worden. Daarbij zou zelfregulering met sanctionering van de overheid hier voorlopig nog een uitzondering op zijn, omdat sanctionering door de overheid niet plaatsvindt. Dat zegt echter nog weinig over het kwaliteitsniveau van de individuele loopbaanprofessional, waar Maas (1999) naar verwijst in het kader van zijn interne criteria voor een professie.

Procesbenadering: Als de acht criteria van Maas als uitgangspunt genomen worden om de beroepsgroep loopbaanadvisering te evalueren, dan zou de conclusie echter anders zijn. Weliswaar werden 'zelfregulering via ethische code door een beroepsvereniging en toezicht door een tuchtcollege zeer hoog beoordeeld en wordt ook het aanwezig zijn van een theoretisch gefundeerd kennisdomein hoog beoordeeld, waardoor loopbaanadvisering in dit opzicht een professie lijkt te zijn. Echter, de andere criteria scoren lager dan 4.

Synthese procesbenadering en conceptbenadering: In tegenstelling tot de conceptbenadering, waarbij gezocht wordt naar het wezen van een professie, benadrukt de procesbenadering door de interactie tussen de stakeholders het dynamische aspect van de ontwikkeling naar een professie. De procesbenadering benadrukt ook de dynamische aspecten door erop te wijzen dat in de dagelijkse praktijk professionals proberen de positie van hun beroepsgroep te ontwikkelen en uit te bouwen. De Sonnaville (2005; p. 100) geeft aan "dat professies goed te begrijpen zijn, als zijnde belangengroepen die in interactie met anderen (overheid, 
universiteit en het grote publiek) een monopolistische positie willen verwerven en die deze voorts verder willen ontwikkelen." Als de uitkomsten van de concept(Greenwood) en de procesbenadering (Maas) vergeleken worden, blijkt dat de acht beroepsgroepen samen op precies dezelfde score uitkomen. Loopbaanadvisering scoort op de criteria van de conceptbenadering hoger dan op de criteria van de procesbenadering.

\subsubsection{Conclusies}

Kernvraag 1 luidde: In hoeverre heeft loopbaanadvisering zich ontwikkeld tot een professie? Het antwoord op deze vraag is gezocht aan de hand van de criteria van Greenwood (1957) en Maas (1999). Voor alle criteria van zowel Greenwood als Maas scoort de loopbaanadvisering gemiddeld hoger dan 3, afgezien van het criterium zelfregulering met sanctionering van de overheid (criterium Greenwood) en een lang proces van scholing, training en ervaring (criterium Maas). De lage score voor het criterium van Greenwood wijst op het ontbreken van een sanctionering van de professie door de overheid. Daarnaast is er nog geen sprake van een lang proces van scholing. De ontwikkeling van een universitaire opleiding voor loopbaanadvisering is immers nog nauwelijks begonnen.

Voor zowel de criteria van Greenwood als van Maas scoort loopbaanadvisering op zeven van de acht criteria voldoende (hoger dan 3) op een vijfpuntsschaal. Dit wijst erop dat loopbaanadvisering zich goed heeft ontwikkeld op weg naar een professie. Zou de lat hoger worden gelegd door te kijken naar een score hoger dan 4, dan zouden zes van de acht criteria van Greenwood en slechts drie van de criteria van Maas voldoen. Dat is minder goed, terwijl men zou kunnen verwachten dat om als beroepsgroep een professie genoemd te worden een gemiddelde beoordeling van minimaal 4 op een vijfpuntsschaal zou passen. 
Kernvraag 1 kan derhalve als volgt beantwoord worden: Loopbaanadvisering heeft zich reeds voldoende ontwikkeld op weg naar een professie. Op verscheidene criteria, waaronder zelfregulering; maatschappelijke steun en erkenning; wetenschappelijke steun en toetsing wie het vak mag uitoefenen, zal loopbaanadvisering zich echter nog verder moeten ontwikkelen om een professie genoemd te worden.

Kernvraag 2 luidde: In hoeverre hebben andere beroepsgroepen, die in de volksmond een professie genoemd worden, zich ontwikkeld tot een professie? Het gemiddelde resultaat van alle beoordelingen van de acht beroepsgroepen tezamen is hoog. Dit ondanks het feit dat het notariaat en de geestelijkheid als beroepsgroep gemiddeld met minder dan 4 beoordeeld werden. De beoordelende experts van genoemde twee beroepsgroepen scoorden hun vakgebied bovendien zelfs minder hoog dan de beoordelaars van de loopbaanadvisering.

Het onderzoek heeft verder uitgewezen dat de andere vakgebieden, die een professie worden genoemd, op alle criteria van Greenwood en Maas hoger dan 3 scoren. Indien er voor "goed" de eis wordt gesteld dat de score hoger dan 4 moet zijn, dan blijken alle criteria op twee na te voldoen. Voor Greenwood is het criterium maatschappelijke steun en erkenning minder dan 4; voor Maas is oplossen van problemen door altruïsme minder dan 4 . Voor alle zestien criteria tezamen scoren de acht professionele experts goed. Derhalve kan kernvraag 2 als volgt beantwoord worden: door een gemiddelde beoordeling van ruim 4, hebben zes van de acht beroepsgroepen zich duidelijk goed ontwikkeld tot een professie; het notariaat en de geestelijkheid in iets mindere mate. Hierbij moet vanzelfsprekend wel in acht worden genomen dat iedere beroepsgroep in het panel slechts door één respondent vertegenwoordigd werd.

Kernvraag 3 luidde: Bestaan er verschillen tussen loopbaanadvisering en andere beroepsgroepen die een professie worden genoemd? Er bestaan verschillen 
tussen loopbaanadvisering en andere beroepsgroepen die een professie worden genoemd. Loopbaanadvisering scoorde wat lager dan de andere beroepsgroepen op de criteria van Greenwood en Maas. Het zou kunnen dat jonge beroepsgroepen als loopbaanadvisering beter scoren op de externe statische criteria van Greenwood, die eenvoudiger en dus ook sneller te realiseren zijn, terwijl er bij de meer 'gesettelde' beroepsgroepen, zoals in dit onderzoek bleek, geen verschil is tussen intern gerichte en extern gerichte criteria. Kernvraag 3 wordt als volgt beantwoord: de gezamenlijke zestien criteria geven een verschil aan tussen loopbaanadvisering en de acht beroepsgroepen die zich een professie noemen, zowel tussen de beoordeling van het totaal van de zestien criteria als tussen sommige criteria afzonderlijk.

Resumerend: Als in het algemeen gevraagd zou worden om een beoordeling van criteria voor een professie te geven, zouden idealiter alle criteria op een schaal van $1-5$ met 5 beoordeeld dienen te worden. Dat is in de praktijk vanzelfsprekend onhaalbaar. Het onderzoek leert dat een gemiddelde score rond 4,50 al bijzonder is. Voor loopbaanadvisering moet in ieder geval nog veel werk verricht worden, met zowel de overheid als met de maatschappij als geheel, om de status te verkrijgen van wat in de volksmond een professie genoemd wordt. Dit betekent dat de maatschappij zal moeten inzien dat het effect van een goede loopbaanadvisering groot is en dat de maatschappij als geheel daarvan kan profiteren.

Van primair belang voor loopbaanadvisering is om te focussen op meer maatschappelijke steun en erkenning. Zonder de erkenning van een groot publiek te krijgen, in de zin dat loopbaanadvies gezien wordt als een vitale dienst voor de maatschappij als geheel, is het nauwelijks mogelijk om de erkenning te krijgen die noodzakelijk is om een professie te worden genoemd. In het onderzoek wordt maatschappelijke steun en erkenning door zowel loopbaanadvies als door de acht 
andere beroepsgroepen lager dan 4 op een schaal van $1-5$ beoordeeld. De auteur van dit proefschrift neemt aan dat de acht respondenten alleen naar maatschappelijke steun gekeken hebben toen ieder van hen een beoordeling $<4.0$ aantekenden. Voor loopbaanadvisering is het krijgen van voldoende maatschappelijke steun en erkenning essentieel voor het verkrijgen van de status van een professie. Opmerkelijk is ook dat de beoordeling van zelfregulering de hoogste score (5) krijgt, terwijl de zelfregulering met de toevoeging 'met sanctionering via de overheid' als laagste beoordeeld wordt.

Een tweede criterium waar een beroepsgroep de status behorende bij een professie mee verdient, is 'legitimatie door de overheid'. Zonder deze legitimatie van de overheid kan een beroepsgroep ook weer bij het grote publiek niet erkend worden als professie. Hoewel loopbaanadvisering in de ogen van de drie beoordelende loopbaanexperts met een beoordeling hoger dan 4 zeer goed scoort, is het maar de vraag of het grote publiek er in gelijke mate over denkt.

Een derde belangrijk criterium voor een professie is de wetenschappelijke steun die een professie krijgt. Voor de acht andere beroepsgroepen is wetenschappelijke steun min of meer vanzelfsprekend. Om zelfstandig te kunnen werken is voor alle acht beroepsgroepen een academische studie op minimaal masterniveau verplicht. De acht beroepsgroepen beoordelen het criterium wetenschappelijke steun dan ook als erg hoog $(4,88)$. Loopbaanadvisering scoort op het criterium van wetenschappelijke steun in onderzoek en onderwijs met 3,33 veel lager. Voor loopbaanadvisering is een opleiding op hbo-niveau minimaal verplicht om lid te worden van de beroepsvereniging Noloc of om te certificeren via CMI. Voor beide instituten is een hbo-diploma in een ander vakgebied ook voldoende om toe te treden. In de jaren negentig van de vorige eeuw was er immers op het terrein van loopbaanadvies nog geen aanbod van opleidingen op hbo-niveau. Thans zijn er 
goede opleidingen voor loopbaanadviseur op hbo-niveau. Maar zowel voor CMI als voor Noloc is een hbo-opleiding in loopbaanadvisering nog geen minimumeis voor toetreding tot de beroepsgroep. Dat dit een verplichting wordt om als zelfstandige in het vakgebied te werken, is dan ook nog niet aan de orde. Die eis zal er in het komende decennium waarschijnlijk wel komen, maar of er voor zelfstandige loopbaanadviseurs een verplichting komt om een opleiding op masterniveau in loopbaanadvies te doorlopen, is nog maar zeer de vraag. De auteur van dit proefschrift zou dit toejuichen op weg naar een professie. Zonder de wetenschappelijke steun van een masteropleiding kan er van een professie nog onvoldoende sprake zijn.

De lage beoordeling voor wetenschappelijke steun voor de beroepsgroep van loopbaanadviseur is vermoedelijk het gevolg van het feit dat het vakgebied jong is, waardoor de primaire eisen voor een professie nog niet uitontwikkeld zijn. Verwacht mag worden dat zowel op het terrein van onderwijs en onderzoek het criterium wetenschappelijke steun zich in de komende jaren verder zal ontwikkelen. De vraag is echter wel of hiervoor voldoende middelen beschikbaar zullen komen. Dat heeft mede te maken met het tempo waarin de maatschappelijke erkenning zich ontwikkelt. Daar kan de beroepsgroep zelf veel aan bijdragen door het geven van lezingen en het gebruik van sociale media in het kader van de promotie van de beroepsgroep. Ook een verdere legitimatie door de overheid kan hieraan bijdragen. Doordat de overheid de certificering van loopbaanadvisering voor de eigen adviseurs reeds verplicht stelt, ligt verdere legitimatie door de overheid voor de hand. Op het gebied van gecertificeerde opleidingen ontwikkelt loopbaanadvisering zich snel. Op hbo-niveau zijn er, naast geaccrediteerde hbo-opleidingen voor loopbaanadvisering, ook een aantal commerciële opleidingen met een goede reputatie. Op wo-niveau is de bachelor- en masteropleiding in ontwikkeling. Accreditatie van deze opleidingen wordt verwacht. 
Zes van de zestien criteria zijn hoger beoordeeld voor loopbaanadvisering dan het gemiddelde van de acht beroepsgroepen, die een professie genoemd worden. Deze criteria zijn: 1) het hebben van een branche- en beroepsvereniging; 2) het hebben van een missie en een visie; 3) het hebben van een beroepscode en een beroepscommissie; 4) legitimatie door de overheid; 5) toezicht op naleving door middel van een tuchtcollege; en 6) zelfregulering, vastgelegd in een ethische (beroeps)code. Daarvan zijn vijf criteria met een 5 beoordeeld en legitimatie door de overheid een fractie lager dan 5 . Ook het hebben van een gecertificeerde opleiding werd zeer hoog beoordeeld, maar werd door de andere acht beroepsgroepen gemiddeld nog een fractie hoger beoordeeld.

Dat legitimatie door de overheid inzake loopbaanadvisering zo hoog scoorde, wil nog niet zeggen dat de overheid de legitimatie voor het gehele vakgebied zonder voorwaarden zal toestaan. Verwacht mag worden dat daar in de komende jaren de volgende voorwaarden aan verbonden zijn om het vak zelfstandig uit te voeren: 1) het behalen van een diploma op hbo-niveau en op termijn op masterniveau in loopbaanadvisering om het vak zelfstandig uit te voeren; 2) een CMI-certificaat op minimaal het B-niveau; 3) specifieke werkervaring van minimaal drie jaar en algemene werkervaring van minimaal zes jaar. Als aan deze drie voorwaarden door de beroepsgroep gehoor gegeven wordt, dan zal de verdere ontwikkeling tot een professie open staan. De andere twee criteria - gezag ontleend aan kennis en toetsing wie het vak mag uitvoeren - zullen immers zonder veel moeite vervuld worden als de overheid op de genoemde voorwaarden de beroepsgroep als geheel zou legitimeren als professie.

Tot slot is het opmerkelijk dat altruïsme relatief laag scoort. Dat heeft mogelijk met de tijdgeest te maken. Hoewel er nog veel mensen zijn die bereid zijn te helpen, vinden anderen dat dit niet ten koste van de eigen portemonnee mag gaan. Zolang 
loopbaanadvies als beroepsgroep niet in staat is de honorering voor haar werkzaamheden op een beter niveau te brengen en te houden, moet gevreesd worden dat altruïsme de weg naar een professie weleens zou kunnen blokkeren.

Een theoretisch gefundeerd kennisdomein scoort als criterium voor loopbaanadvisering op weg naar een professie hoog. De belangenvereniging Noloc ontwikkelde vroeg na de eeuwwisseling een Body of Knowledge and Skills. Of hieraan voldoende gezag wordt ontleend, is echter maar de vraag. Loopbaanadvisering wordt door de experts op het criterium controle op kwaliteit lager dan 4 beoordeeld. Dat verbaast enigszins, omdat de certificering bij uitstek een controle op kwaliteit wil bevorderen. Loopbaanadvisering is volgens de experts met betrekking tot het criterium wie het vak mag uitoefenen nog in ontwikkeling. De beroepsgroep zal dit eerst moeten waarmaken, door bij te dragen aan goede en geaccepteerde opleidingen en specialisaties op het gebied van loopbaanadvisering. De overheid zal tenslotte moeten bepalen wie het vak zelfstandig zal mogen uitvoeren. In de huidige ontwikkelingsfase van de beroepsgroep mag iedereen die zich tot het vakgebied aangetrokken voelt zonder enig diploma noch ervaring het vak beoefenen.

\subsubsection{Beperkingen}

De belangrijkste beperking is dat dit onderzoek naar een professie gebaseerd is op een zeer klein aantal respondenten. Hierdoor is de betrouwbaarheid van de uitkomsten van het expertpanel gering. Derhalve moet uitdrukkelijk gesteld worden dat de uitkomsten slechts een eerste indruk geven inzake de vraag in welke mate loopbaanadvisering zich heeft ontwikkeld tot een professie. Bovendien hebben de professionele experts alleen de criteria voor hun eigen beroepsgroep beoordeeld (self-report). Zij waren voor de beoordeling van hun eigen beroepsgroep als expert 
uitgenodigd, maar werden niet verondersteld expertise te hebben op het terrein van andere beroepsgroepen. Op zich is dat een welbewust gekozen beperking, omdat alle respondenten slechts expert zijn op het terrein van hun eigen beroepsgroep.

Validiteit: de interne validiteit is bij praktijkgericht onderzoek veelal laag, wat hier nog versterkt wordt door het geringe aantal waarnemingen. Daarentegen is de externe validiteit hoog, omdat de relevante criteria door topexperts met jarenlange ervaring op het terrein van de negen beroepsgroepen zijn beoordeeld.

\subsubsection{Aanbevelingen}

Op basis van de bevindingen van het onderhavige exploratieve onderzoek kunnen verschillende aanbevelingen worden gedaan. Ten eerste wordt aanbevolen om voor loopbaanadvisering een veel groter onderzoek op te zetten op basis van de criteria van Greenwood en Maas. Een groter onderzoek moet mogelijk zijn als ook de betreffende branche- en beroepsvereniging hun medewerking willen verlenen. Een dergelijk nieuw onderzoek zou leiden tot meer betrouwbare uitkomsten voor zowel loopbaanadvisering als voor de andere beroepsgroepen. Derhalve beveelt de auteur een dergelijk onderzoek van harte aan. Om te beginnen met een onderzoek onder Noloc- én OVAL-leden of onder Register Loopbaanprofessionals van CMI.

Ten tweede kunnen op basis van de bevindingen van dit onderzoek verschillende praktische aanbevelingen gedaan worden. In het onderzoek zijn wetenschappelijke steun en maatschappelijke erkenning de moeilijkst realiseerbare criteria. Voor wetenschappelijke steun is het opzetten van een opleiding voor zowel het bachelor- als het masterniveau in volle gang gekomen. Een studierichting op hbo-niveau voor loopbaanadvisering bestaat reeds. Dit zal uitgebouwd moeten

worden, zodat er binnenkort een geaccrediteerde studierichting Loopbaanadvisering op wo-niveau ontstaat. 
De tweede praktische aanbeveling is om een masterdiploma te eisen voor de zelfstandige uitvoering van loopbaanadvisering. Die eis is veel moeilijker te realiseren. In eerste instantie moet de beroepsgroep een dergelijke ontwikkeling naar een professie zelf willen aanbevelen. Het is maar de vraag of hiervoor een meerderheid te vinden zal zijn. Deze eis heeft ook te maken met de legitimatie door de overheid en de maatschappelijke erkenning. Legitimatie door de overheid zal op zich niet problematisch zijn als maatschappelijke erkenning verworven is. Wel zal dan, naast het masterdiploma, ook certificering na een aantal jaren werkervaring op CMI C-niveau geëist dienen te worden. Maar legitimatie door de overheid is minder een probleem: de overheid is reeds de grootste klant van CMI als het om certificering gaat. Alle loopbaanadviseurs worden geacht zich bij CMI te laten certificeren. Dat steunt in hoge mate de legitimatie door de overheid. Om loopbaanadvisering te kwalificeren als een professie is echter maatschappelijke steun en erkenning noodzakelijk. De beroepsgroep zal daar zelf voor moeten lobbyen. Allereerst door alle leden van Noloc drie jaar na hun aanmelding voor te dragen voor certificering en te stimuleren dat alle Noloc-leden die zelfstandig willen werken, naast certificering op C-niveau, een masterdiploma dienen te halen.

Vervolgens zal ook de overheid ervan overtuigd moeten worden dat loopbaanadvisering essentieel is voor de duurzame inzetbaarheid van de beroepsbevolking. Voor de realisatie van deze laatste aanbeveling is natuurlijk tijd nodig. Waar het om gaat is de overtuiging dat de beroepsgroep, als redder van mensen in werknood, een essentiële plaats dient in te nemen in het maatschappelijke bestel, om vervolgens hiervoor maatschappelijke steun en erkenning te verwerven. Daarvoor zal er door de beroepsgroep zelf veel meer inzet gerealiseerd moeten worden om het grote publiek duidelijk te maken dat het begeleiden van mensen in werknood groot effect heeft, zoals elders in dit proefschrift wordt aangetoond. 
Gezien de lage beoordeling voor zowel loopbaanadvies als voor de acht andere beroepsgroepen inzake altruïsme en maatschappelijke erkenning zou het kunnen zijn dat er een samenhang bestaat tussen altruïsme en maatschappelijke erkenning. Immers, maatschappelijke steun en erkenning wordt pas gegeven als men het gevoel heeft dat een beroepsgroep bereid is te helpen. 


\section{HOOFDSTUK 4}

\section{ETHIEK ALS BASIS VOOR HET HANDELEN \\ VAN DE LOOPBAANADVISEUR}

\subsection{Inleiding}

Evenals in andere sociaal-maatschappelijke disciplines staat de cliënt ook centraal bij de advisering van zijn of haar loopbaan (Watts, 1999). Daarbij is ethiek steeds de basis voor het handelen van de loopbaanadviseur. Immers, zonder overtuigd te zijn dat de loopbaanadviseur ethisch handelt, zullen weinig cliënten beginnen aan een proces van begeleiding. Het is noodzakelijk dat cliënten voldoende vertrouwen hebben dat de adviseur het goede met hen voor heeft. Zonder die basis kan er van een vertrouwensrelatie tussen de cliënt en zijn loopbaanadviseur geen sprake zijn. Zonder ethisch te handelen kunnen loopbaanadviseurs derhalve hun vak niet uitoefenen.

Ethisch handelen en het daaraan voorafgaande ethische besef ${ }^{1}$ zijn daardoor hoekstenen voor het vakgebied. Er is echter nog niet eerder onderzoek gedaan naar

\footnotetext{
${ }^{1}$ Hieronder volgen de omschrijvingen die de Dikke Van Dale geeft inzake ethiek en aanverwante begrippen. Deze definities over ethiek en zeden sluiten goed aan bij het ethisch handelen van een loopbaan-adviseur, door de toevoeging dat het 'in kleinere kring' gedragingen en handelingen zijn, die algemeen als goed en aanvaardbaar worden gekenschetst.

- $\quad$ ethiek: zedenleer, praktische wijsbegeerte, die handelt over zedelijke begrippen en gedragingen; over wat goed en wat kwaad is;

- $\quad$ ethisch handelen: zich houden aan ethische normen;

- $\quad$ ethisch besef: een goede voorstelling van ethisch handelen. Gaat aan het ethisch handelen vooraf.

- $\quad$ dilemma: de toestand waarin tussen twee wegen, die beide grote bezwaren opleveren, een keuze gemaakt moet worden;

- $\quad$ ethisch dilemma: een situatie waarbij iemand verschillende keuzes tot handelen heeft, die betrekking hebben op moraliteit. Deze beslissing kan uitmonden in onwenselijke situaties. Een ethisch dilemma bevat altijd verschillende waarden;

- $\quad$ zeden: maatschappelijke handelswijze die in kleinere of grotere kring algemeen in gebruik of traditioneel van kracht is en 'goed' genoemd wordt.
} 
ethisch handelen en ethisch besef in het vakgebied (Heppner \& Heppner, 2003). Doordat Career Management Institute Netherlands $(\mathrm{CMI})^{2}$ als certificerende instelling voor loopbaanadvisering een hoofdstuk over ethiek in het dossier van de kandidaten voor certificering heeft opgenomen, zijn er voldoende casusvoorbeelden voorhanden om hiernaar onderzoek te doen.

Dat ethiek voor het vakgebied een belangrijk gebied is om onderzoek naar te doen, heeft nog een andere reden. Bij loopbaanadvisering is er immers naast de vertrouwensrelatie met de cliënt in de meeste gevallen ${ }^{3}$ tevens een vertrouwensrelatie met de opdrachtgever, die het begeleidingsproces financiert. Daardoor hebben opdrachtgever en cliënt zowel een gemeenschappelijk belang (bijvoorbeeld: het beter functioneren van de cliënt) als een mogelijk tegenstrijdig belang (de privacy van de cliënt versus de rapportage van de adviseur over de cliënt aan de opdrachtgever). Omdat de cliënt en de opdrachtgever tegenstrijdige belangen kunnen hebben, kan er een potentieel spanningsveld ontstaan, waar ook de adviseur deel van uit kan maken. Dit spanningsveld kan aanleiding geven tot ethische dilemma's. De adviseur moet deze ethische dilemma's bij voorkeur voorkomen en wanneer deze niet te vermijden zijn, met een goede oplossing komen voor alle betrokken partijen.

Vanwege het spanningsveld in de verhouding cliënt, opdrachtgever en adviseur, ligt het ontstaan van ethische dilemma's steeds op de loer. Daarom vraagt CMI bij de certificering, naast aandacht voor de gedragscode, ook aandacht voor het ethisch dilemma. Dit doet CMI door de kandidaten voor certificering te vragen een

${ }^{2}$ Er is door het CMI-bestuur toestemming gegeven om dit onderzoek te doen.

${ }^{3}$ Er zijn ook privépersonen die een loopbaanadviseur in de arm nemen bij de oplossing van een loopbaanprobleem. In dat geval is er geen sprake van een spanningsveld. De kosten van een dergelijke ondersteuning zijn echter in de meeste gevallen te hoog voor privépersonen. 
casusvoorbeeld te schrijven over een ethisch dilemma in het kader van de driehoeksrelatie cliënt, opdrachtgever en adviseur, tijdens de begeleiding van één van hun cliënten.

Omdat verwacht werd dat ethisch handelen van loopbaanadviseurs zich in stadia ontwikkelt, werd besloten om, in analogie met Piaget (1932) en Kohlberg (1958), onderzoek te doen naar de ethische ontwikkelfasen van de loopbaanadviseur. Daarbij werden de casusvoorbeelden van de te certificeren loopbaanadviseurs gecategoriseerd naar de ontwikkelstadia van ethisch handelen, waarna de scores van de loopbaanadviseurs op alle drie de CMI-niveaus met elkaar werden vergeleken. CMI onderscheidt drie niveaus van vakbekwaamheid, naargelang de kandidaat meer in de breedte van het vakgebied werkt. Niveau A: de kandidaat werkt uitsluitend met cliënten. Niveau B: als A, maar de kandidaat werkt tevens met opdrachtgevers. Niveau C: als B, maar de kandidaat geeft tevens beleidsadviezen aan organisaties. Daarnaast wordt bij de inschrijving als kandidaat voor certificering ook gevraagd naar het aantal jaren ervaring als loopbaanadviseur. Voor het CMIniveau A is drie jaar ervaring vereist. Voor CMI-niveau B vijf jaar en voor CMIniveau C zes jaar (www.cmi.nl).

De door de loopbaanadviseurs ingebrachte casusvoorbeelden kunnen worden ingedeeld in vijf ontwikkelstadia:

1) Het spanningsveld tussen adviseur, cliënt en opdrachtgever wordt niet onderkend en derhalve niet beschreven.

2) Het spanningsveld tussen adviseur, cliënt en opdrachtgever wordt onderkend en beschreven, echter zonder een dilemma binnen het spanningsveld te beschrijven.

3) Het spanningsveld tussen adviseur, cliënt en opdrachtgever wordt wel onderkend en een dilemma wordt beschreven, maar dit betreft geen ethisch dilemma. 
4) Het spanningsveld tussen adviseur, cliënt en opdrachtgever wordt onderkend en een ethisch dilemma wordt beschreven, echter zonder een oplossing.

5) Het spanningsveld tussen adviseur, cliënt en opdrachtgever wordt onderkend en een ethisch dilemma wordt beschreven, met een goede oplossing.

De vijf ontwikkelstadia van ethisch handelen volgen elkaar op. De ontwikkeling van stadium één naar stadium vijf geeft, net als bij Kohlberg (1958), een te verwachten ontwikkelproces aan, waarbij het volgende ethisch stadium de voorafgaande stadia incorporeert.

\section{Kernvragen}

Met het huidige onderzoek is getracht inzicht te verkrijgen in een drietal vragen. Ten eerste, zonder ethisch handelen kan een loopbaanadviseur het loopbaanvak niet uitoefenen. Onderzocht werd of door de te certificeren loopbaanadviseurs voldoende ethisch besef is opgebouwd om aan de eis van CMI, om een casusvoorbeeld van een ethisch dilemma te beschrijven, te kunnen voldoen. De eerste kernvraag luidde daarom als volgt:

Kernvraag 1: Heeft de loopbaanadviseur voldoende ethisch besef ontwikkeld om aan de eis van CMI te voldoen om ethisch te kunnen handelen?

Ten tweede, bij de CMI-certificering worden de loopbaanadviseurs ingedeeld in drie niveaus. Onderzocht werd of er een relatie is tussen de ontwikkelstadia van ethisch handelen van de loopbaanadviseur en diens CMI-niveau. 
Kernvraag 2: Is er een relatie tussen het ethische ontwikkelstadium van de loopbaanadviseur en diens CMI-niveau?

Ten derde werd onderzocht in hoeverre de leeftijd, gender, opleiding en de algemene en specifieke werkervaring van de loopbaanadviseur samenhangen met zowel diens ethische ontwikkelstadium als CMI-niveau:

Kernvraag 3: Is er een relatie tussen de achtergrondvariabelen (leeftijd, gender, opleiding, en algemene en specifieke werkervaring) van de loopbaanadviseur en diens ethische ontwikkelstadium en CMI-niveau?

De verdere opbouw van dit hoofdstuk is als volgt: eerst wordt in paragraaf 4.2 ingegaan op de gehanteerde onderzoeksmethodiek. Vervolgens worden in paragraaf 4.3 de resultaten van het onderzoek besproken. In paragraaf 4.4 worden ten slotte conclusies getrokken uit het onderzoek en volgt de discussie.

\subsection{Methodiek van onderzoek naar ethisch handelen van loopbaanadviseurs}

\subsubsection{Design}

Het onderzoek is exploratief, beschrijvend van aard en richt zich op de periode 2012 - 2014. In deze periode zijn 170 casusvoorbeelden over een ethisch dilemma uit de CMI-dossiers van de te certificeren loopbaanadviseurs verzameld. Deze worden anoniem gebruikt voor het onderzoek. Het onderzoek met betrekking tot ethiek betreft een eigen ontwikkelmodel, analoog aan het ontwikkelmodel van Kohlberg (1958). Met behulp van statistische analyses, gericht op de drie kernvragen van het onderzoek, worden de relaties tussen de ontwikkelstadia en het niveau van 
de loopbaanadviseur, alsmede de achtergrondvariabelen van de loopbaanadviseur, geanalyseerd.

\section{Casus- of gevalsmethodiek ${ }^{4}$}

De casus- of gevalsmethodiek wordt in adviserende sociaal-maatschappelijke vakgebieden veel toegepast (Swanborn, 1996). Vakgenoten zijn gewend om van elkaars ervaring te leren door elkaar casusvoorbeelden aan te leveren. Het doel hierbij is steeds om elkaar feedback te geven op het eigen handelen, waardoor kwaliteitsborging plaatsvindt. Om geschikt te zijn voor deze methodiek moet de casus voldoen aan een aantal pragmatische criteria (Segers, 1999): de casus moet levensecht zijn; de problematiek moet afgebakend zijn; de probleemstelling moet 'open' zijn; er moet een stimulerende werking van uit gaan en de problematiek moet een aansporing bevatten.

Vooral bij intervisie en supervisie wordt gebruik gemaakt van de casus- of gevalsmethodiek. Een van de bekendste methodes is die van de Hongaarse arts Michael Balint (1954), die in de jaren vijftig van de twintigste eeuw een eigen gevalsmethodiek ontwikkelde in het kader van de intervisie voor huisartsen ${ }^{5}$. Bij intervisie wordt een strak schema aangehouden met de bedoeling dat er een leereffect uitgaat van iedere gevalsstudie (Segers, 1999). Het leerproces van de gevalsstudie, mits consequent toegepast, versterkt de intrinsieke motivatie. Ook levert het een groot leerrendement op, waarbij een voorbeeld uit de praktijk meer rendement oplevert dan een theoretische analyse, vanwege de levensechte problematiek (Pederson, 2004). Het leerproces biedt tevens optimale mogelijkheden

\footnotetext{
${ }^{4}$ Gewoonlijk wordt het Engelse woord 'case study' gebruikt.

${ }^{5}$ In Nederland werd de Balint methode geïntroduceerd door de huisarts Dr. A. H. van Lidth de Jeude.
} 
om theorie en praktijk aan elkaar te koppelen (Segers, 1999). De casus- of gevalsmethodiek wordt in verschillende studies toegepast (Hutjes \& Van Buuren, 1996). De casus- of gevalsstudie is zowel cognitief als affectief; met andere woorden, de casusvoorbeelden hebben zowel inhoudelijke- als gevoelselementen ${ }^{6}$.

De casus- of gevalsmethodiek toegepast bij ethisch handelen van de loopbaanadviseur

De casus- of gevalsmethodiek wordt bij loopbaanadvies veelvuldig gebruikt in het kader van (intercollegiale) toetsing7. CMI vraagt de kandidaten in het kader van het dossier voor certificering om twintig casusvoorbeelden en twee gevalsstudies aan te leveren, om de verschillende aspecten van het vakgebied te beschrijven. Aan de kandidaten voor CMI-certificering wordt gevraagd om twee casusvoorbeelden over ethisch handelen te schrijven, te weten:

Casus 1: een beschrijving van een ethisch dilemma in het spanningsveld tussen adviseur, cliënt en opdrachtgever;

Casus 2: een beschrijving van een casusvoorbeeld 'naar keuze' over de wijze waarop de adviseur omgaat met de CMI-gedragscode ${ }^{8}$ (zie www.cmi.nl).

Zelf heeft CMI viermaal een boekje uitgegeven waarin bijzondere voorbeelden van gevalsstudies zijn gebundeld onder de titel: ‘Loopbaanbegeleiding in de praktijk' (CMI, 1999; 2003; 2007; 2014). Deze boekjes worden door CMI zelf

\footnotetext{
${ }^{6}$ Uit eigen ervaring wordt geconstateerd dat veel loopbaanadviseurs, na de toetsing voor certificering, beseffen dat juist de beschrijving van de casusvoorbeelden hen in hoge mate motiveert om met nog meer enthousiasme door te gaan met hun ontwikkeltraject.

${ }^{7}$ Bij CMI wordt onderscheid gemaakt tussen casusvoorbeelden en case studies. De case study heeft ook bij CMI een vaste indeling, waardoor het geschikt is voor onderzoek. Het casusvoorbeeld heeft geen vaste indeling. Het onderscheid is duidelijk af te lezen uit de twee voorbeelden uit de certificeringspraktijk hieronder.

${ }^{8}$ De gedragscode behandelt naast ethiek ook zaken als privacy en geheimhouding.
} 
samengesteld aan de hand van geanonimiseerde gevalsstudies uit de dossiers van kandidaten voor certificering. Geregeld worden nieuwe gevalsstudies in een nieuwe druk opgenomen, omdat casussen na verloop van tijd door de ontwikkeling van het vakgebied gedateerd raken, waardoor zij niet meer geschikt zijn om als studiemateriaal te dienen. Hieronder worden de twee casussen die CMI bij de certificering voorschrijft besproken. Daarna worden twee voorbeelden van beide soorten casussen gegeven.

Casus 1: Het ethische dilemma in het spanningsveld tussen adviseur, cliënt en opdrachtgever. Onderstaand kader beschrijft een casusvoorbeeld waarbij door een adviseur (Lies Pol, RL; tekst gepubliceerd met toestemming) wordt aangegeven hoe zij een ethisch dilemma in de driehoeksrelatie met cliënt en opdrachtgever behartigt en oplost (zie Figuur 4.1).

Casus 2: Omgaan met de CMI-gedragscode voor ethisch handelen bij loopbaanadvisering. De door CMI te certificeren adviseur wordt in het kader van ethiek door CMI gevraagd om, naast een voorbeeld van de 'driehoeksrelatie', een tweede voorbeeld naar keuze te geven met betrekking tot de wijze waarop de loopbaanadviseur het naleven van een artikel van de gedragscode toepast (zie Figuur 4.2).

Volgens de Dikke Van Dale (1992, p. 915) wordt onder een gedragscode verstaan: "een verzameling voorschriften met betrekking tot het gedrag op een bepaald gebied". Doordat de gedragingen in ieder vakgebied anders zijn, is de verzameling voorschriften in ieder vakgebied verschillend, maar uiteraard op het vakgebied gericht. Zo heeft de Vereniging van Samenwerkende Universiteiten in Nederland (VSNU) in 2004 een gedragscode voor wetenschapsbeoefening vastgesteld, waarin de principes voor wetenschapsbeoefening zijn vastgelegd. 
"Cliënt werkt als controller bij een grote organisatie. Hij heeft een nieuwe directeur en voelt in toenemende mate dat hij een slechte match maakt met deze directeur. Een collega coacht cliënt om beter te functioneren. Dit lukt ten dele; er komt wat verlichting in de samenwerking. Na een half jaar komt er een verzoek aan mij om de directeur en cliënt te begeleiden om beter samen te werken. Tijdens deze begeleiding voel ik als coach dat zij nooit bij elkaar zullen komen. De directeur is eisend in zijn gedrag en cliënt projecteert allerlei oude zaken op deze man. Cliënt wordt steeds onmachtiger en is ten einde raad, maar durft niet de stap te zetten om weg te gaan. Hij krijgt fysieke klachten, maar durft niet te bewegen. Mijn inschatting is dat dit minstens een half jaar gaat duren. Mijn voorspelling is dat cliënt ziek wordt en de directeur wacht gewoon af welke ontwikkelingen er zullen komen. Beiden zijn naar mijn mening gevangen en verlamd. Ik maak een afweging, bespreek deze niet voor met cliënt en besluit voor te stellen om in overweging te nemen afscheid te nemen van elkaar. Het klopt wat ik dacht: beiden willen dit graag, maar niemand wil dit als eerste gezegd hebben. Cliënt kan hierdoor mogelijk zijn belangen schaden, nl. hij vraagt ontbinding. De directeur wil niet gezegd hebben dat hij het functioneren onvoldoende vindt, want dit past niet bij zijn stijl van leidinggeven en hij heeft geen dossier. Ik ga dus op de stoel zitten van de directeur en doe het voorstel naar beide partijen.

Mijn ethisch dilemma was: wacht $i k$ af tot er vanzelf een beslissing valt en laat ik de verantwoordelijkheid waar deze hoort, of kies ik voor een hopelijk effectieve interventie. Door met hen beiden in elkaars aanwezigheid te verkennen hoe het zou zijn als er eventueel beëindigd zou worden, kwam er beweging. Ik ben van mening dat ik een interventie heb gepleegd die effectief was. K. was wantrouwend of de directeur echt toe zou stemmen in een nette afscheidsregeling. Maar hier was de directeur buitengewoon betrouwbaar. Cliënt is begeleid door een jurist en er is een fantastisch aanbod uitgekomen. Inmiddels begeleiden wij hem in outplacement en zit hij goed in zijn vel. Ik vind dit een treffend voorbeeld van de driehoeksrelatie cliënt en opdrachtgever, nl. hoe behartig ik de belangen van zowel de cliënt als die van de opdrachtgever. Die belangen weeg ik af met mijn ervaring en mijn durf om te benoemen wat ik zie."

Figuur 4.1. Een casusvoorbeeld inzake het ethische dilemma in het spanningsveld tussen adviseur, cliënt en opdrachtgever van Lies Pol, RL (2011).

De uitwerking daarvan omvat onder meer: eerlijkheid; betrouwbaarheid; controleerbaarheid; onpartijdigheid en onafhankelijkheid. In de CMI-gedragscode wordt aangegeven wat CMI verstaat onder de ethische normen voor loopbaanadvisering, namelijk "gedragingen en handelingen die in zekere (kleine) kring 
algemeen als goed en geoorloofd gelden en als zodanig aanvaard worden als ethische norm" ${ }^{9}$

De gedragscode wijkt weinig af van wat er in het algemeen verstaan wordt onder wat ethisch geoorloofd is, maar dan toegepast op het vakgebied van loopbaanadvisering (Reynaert \& Spijkerman, 1995). Bij aanpalende vakgebieden, zoals bij de Nederlandse Orde voor Beroepscoaches (NOBCO) wordt zelfs gesproken van een 'ethische' gedragscode, waarin tevens zaken als respect, integriteit, verantwoordelijkheid en professionaliteit opgenomen zijn. Bij CMI en ook bij de beroepsorganisatie Noloc $^{10}$ worden deze aspecten meer impliciet behandeld.

Helaas wordt "het naleven van de gedragscode naar keuze" door de kandidaten voor certificering meestal geïnterpreteerd als beschrijving van ethisch handelen met inachtneming van de gedragscode. Daardoor zijn er nauwelijks verwijzingen naar de toepassing van specifieke artikelen van de CMI-gedragscode. Daar waar wel verwezen wordt naar artikelen van de gedragscode, wordt veelvuldig artikel 6 aangehaald:

"De basis voor de activiteiten in het kader van loopbaanadvisering (loopbaanbegeleiding, loopbaan coaching en outplacement) wordt gevormd door een goede werkrelatie tussen de betrokken partijen. De onafhankelijkheid van de loopbaanprofessional ten opzichte van zowel de cliënt als de opdrachtgever/ leidinggevende (in de 'driehoeksrelatie'), is daarbij een vereiste. De loopbaan-

\footnotetext{
${ }^{9}$ Zie: (www.cminl.nl).

${ }^{10}$ Noloc: De beroepsvereniging voor loopbaanadvisering: sinds 2008 is Noloc de officiële naam (en dus geen afkorting) voor de beroepsvereniging van loopbaanadviseurs geworden; voor 2008 was NOLOC de afkorting voor Nederlandse Organisatie voor Loopbaan en Outplacement Consultants.
} 
professional mag daarbij uitsluitend de rol van loopbaanprofessional vervullen en wordt niet geacht deze rol te combineren met andere rollen in relatie tot de cliënt."

Over artikel 6 is binnen CMI strijd gevoerd. In de praktijk komt het meermalen voor (met name bij de overheid) dat bij reorganisaties een groep medewerkers, die overtollig is, in een afgezonderde afdeling wordt geplaatst, gericht op het zoeken naar een baan buiten de organisatie. Daarbij worden de overtollige medewerkers begeleid door een op de loonlijst staande loopbaanadviseur. Op deze wijze worden diverse rollen samengevoegd, hetgeen in de CMIgedragscode verboden is. Een schitterend voorbeeld van een gevalsstudie met een streng doorgevoerde structuur, werd beschreven door adviseur Channah van Dootingh (2016) in het kader van de dossiervorming van haar certificering. Deze beschrijving heeft betrekking op artikel 6 van de CMI-gedragscode, waarin het ethisch besef naar voren komt.

\section{"Situatiebeschrijving}

Het gaat om een grootscheepse reorganisatie, waarbij 500 fte herplaatskandidaten begeleid moeten worden naar ander werk, hetzij binnen, hetzij buiten de organisatie. De reorganisatie vindt plaats in het kader van vernieuwde bedriffsvoering. De opdrachtgever is het bestuur met als directe samenwerkingspartner de directeur HRM. De CAO geeft 13 maanden ontslagbescherming. In deze periode worden deze medewerkers door de afdeling 'Van Werk naar werk' ('W naar W') begeleid naar ander werk. De herplaatsings$k a n d i d a a t$ komt dan in dienst van de ' $W$ naar $W$ ' en niet meer in dienst bij de eigen eenheid. Dit betekent dat de 'W naar W' tevens de rol kan hebben van leidinggevende en personeelsadviseur. Met name dit laatste punt wil ik bespreken in deze case, aangezien $i k$ als loopbaanadviseur/trainer verbonden was aan de 'W naar W'. De uitgangspunten in de begeleiding zijn het leveren van maatwerk en het doel is vinden van functie binnen/ buiten de organisatie. Medewerkers die na 13 maanden geen andere functie hebben worden begeleid door een 'externe' arbeidsmarktorganisatie. De opzet en uitrol van de 
reorganisatie wat betreft beleidsvoorbereiding en -uitvoering valt niet onder ' $W$ naar $W$ ' en laat ik derhalve buiten beschouwing.

Probleemanalyse

'W naar $W^{\prime}$ heeft als doel zo veel mogelijk medewerkers te plaatsen binnen een tijdspanne van 13 maanden. De organisatie heeft niet eerder op zo'n grote schaal medewerkers begeleid naar ander werk. Veel medewerkers met vast dienstverband zijn lange tijd in dienst en veel zijn boven de 40 jaar; Alle diensten krimpen in door reorganisatie. De reorganisatie verloopt gefaseerd over 3 jaar binnen alle diensten; De laatste dienst die gereorganiseerd wordt is HRM; Loopbaanadviseurs van de 'W naar $W$ ' worden als laatste zelf ook herplaatst.

Werkwijze

Herplaatsingskandidaten stromen gefaseerd per dienst inbinnen 'W naar $W Z^{\prime}$; echter wel steeds in aantallen van tussen vijf en twintig medewerkers. Deze worden verdeeld over 3 a 4 collega-loopbaanadviseurs en mijzelfom begeleid te worden naar ander werk. De kandidaten worden in een eerste gesprek geïnformeerd over hun rechten, plichten zoals beschreven in hetsociaal plan. 'W naar $W$ ' is verantwoordelijk voor naleving van deze rechten en plichten. Uitvoeringslocatie is het hoofdgebouw. De kandidaten worden gemiddeld eens in de twee weken individueel begeleid. Daarnaast worden er workshops aangeboden. Deze zijn door mij ontwikkeld en zijn mede door mij uitgevoerd. Het gaat om de workshops: veerkracht; verwoorden; inventariseren competenties; schriftelijk solliciteren, mondeling solliciteren en LinkedIn. De kandidaten hebben voorrang op interne vacatures. 'W naar $W^{\prime}$ is verantwoordelijk voor het matchen van vacatures en het toezien dat sollicitatieprocedure conform de herplaatsrichtlijnen wordt uitgevoerd. Loopbaanadviseurs zijn dan ook bij sollicitatiegesprekken aanwezig. In het eerste jaar van de reorganisatie ben ikgestart met het begeleiden van zowel vaste als tijdelijke medewerkers binnen ' $W$ naar $W$ '. Echter de verschillende rollen die ik uitvoerde van zowel loopbaanadviseur/trainer enerzijds en,indiennodig, als de rol van leidinggevende en personeelsadviseur (binnen de kaders van het sociaal plan) anderzijds, vond ik niet (ethisch) verenigbaar. Mijn visie is dat ik mij ten alle tijden als onafhankelijk adviseur dien op te stellen en in eerste instantie de loopbaanontwikkeling van de kandidaat dien en binnen de organisatie een zo neutraal mogelijke positie moet 
nastreven. In de rol van leidinggevende en personeelsadviseur moest ik soms ook meerdere belangen van meerdere partijen dienen binnen de organisatie. Dit druiste in tegen mijn gevoel en kon ik niet verenigen met mijn visie op het loopbaanvak. Simpel gezegd werd iker ongelukkig en gestrest van. Na 1jaar is in overleg besloten dat ik mij om reden van tegengestelde belangen zou richten op de begeleiding van medewerkers meteen tijdelijk contract. Deze tijdelijke medewerkers hadden niet zodanige rechten dat zij bijvoorbeeld in bezwaar konden gaan of juridische stappen kondenondernemen. Binnen 'W naar $W$ ' was ik medeverantwoordelijk voor de communicatie en verantwoording richting diverse belanghebbende partijen als Directeur HRM/Raad van Bestuur/afdeling Communicatie/leidinggevenden en personeelsadviseur. Daarnaast had ik een adviserende rol bij het uitvoeren van beleidsmaatregelen gerelateerd aan de reorganisatie. Algemene werkwijze

Het primaire doel is het vinden van een passende functie binnen/buiten de huidige organisatie. De door mij gehanteerde werkwijze had als resultaat dat de kandidaten: zich zelfstandig op de arbeidsmarkt kannen presenteren; netwerkgesprekken kunnen organiseren en zelfstandig kunnen voeren; relevante vacatures kunnen vinden; een relevant co en brief kunnen presenteren; sollicitatiegesprekken kunnen voeren; aan de hand van een sollicitatieactieplan zelfstandig verder kunnen.

Acties door mij ingezet

Het opstellen van een zoekprofiel; cv aanpassen aan zoekprofiel; arbeidsmarktonderzoek opzetten en uitvoeren; workshop LinkedIn volgen; workshop netwerken volgen; workshop solliciteren volgen; oefenen in profileren en presenteren; vergroten arbeidsmarktvaardigheden zoals het vinden van vacatures, mondelinge en schriftelijke presentatie, solliciteren en netwerken; wekelijks toezenden van het totale aanbod vacatures evenals andere interne en externe vacatures; coaching, bestaande uit het voor-en nabespreken van sollicitatiegesprekken en netwerkgesprekken; benaderen van netwerkcontacten buiten om plaatsing binnen de genoemde termijn te realiseren.

Resultaten

Alle herplaatskandidaten zijn begeleid binnen ' $W$ naar $W$ '. Medewerkers zijn uitgestroomd naar functies binnen of buiten of gestart als zzp'er. Ook is een 
deel met prepensioen gegaan of heeft er zelf voor gekozen het dienstverband voortijdig te beëindigen. In totaal hebben 18 kandidaten na 13 maanden herplaatstermijn geen andere functie gevonden en worden begeleid door een externe arbeidsorganisatie. Dit zijn merendeels 50+kandidaten met eenzijdige werkervaring.

Relevante conclusie inzake de professie

Bij aanvang van de reorganisatie was ik op de hoogte dat ik verschillende rollen (loopbaanadviseur, trainer, coach, leidinggevende, personeelsadviseur) toebedeeld kon krijgen. De herplaatskandidaten kwamen in dienst van de 'W naar $W^{\prime}$ en konden daardoor hun leidinggevende of personeelsadviseur niet meer benaderen. Dit betekende dat ik onder meer sociaal plan met alle rechten en plichten moest toelichten en handhaven; pensioenrechten moest uitleggen; premies moest uitrekenen; selecteur was en kandidaten moest matchen aan interne vacatures, waarbij of de kandidaat of de eenheid kon aangeven, dit niet acceptabel te vinden. Een aantal herplaatskandidaten vertoonden daardoor weerstand of waren boos. Ik was geen neutraal, onafhankelijk loopbaanadviseur meer. Twee punten die voor mij van belang waren, dat ik geen personeelsadviseur, noch selecteur wilde zijn, omdat ik mezelf dan niet meer neutraal en onafhankelijk kon voelen als leidinggevende. Daarnaast wilde ik deze rollen vanuit ethisch oogpunt niet. Het dienen van mijn cliënt en op een onafhankelijke wijze kunnen aansluiten bij hun ontwikkeling en behoefte staat bij mij voorop. Ik heb niet erg lang hoeven wikken en wegen voordat ik dit dilemma aankaartte binnen de organisatie. Binnen HRM had men begrip voor mijn dilemma en waarschijnlijk werd dat begrip ook nog wat vergroot doordat ik zelf ook binnen een bepaalde termijn de herplaatsstatus zou krijgen. Het was een leerzame ervaring en heeft mijn visie en conclusie versterkt om ten allen tijden een zo onafhankelijk mogelijke positie in te nemen, waarbij begeleiding en loopbaanontwikkeling van de cliënt voorop staat."

Figuur 4.2. Reorganisatie: Een case study inzake CMI-gedragscode artikel 6 door Channah van Dootingh, RL (2016). 


\section{Beoordeling CMI-niveaus van te certificeren loopbaanadviseurs}

In de praktijk van certificerende instellingen wordt er in de werkniveaus van de te certificeren adviseurs veelal onderscheid gemaakt tussen drie groepen, waarbij de ervaring het onderscheidende kenmerk is. De internationaal werkende zusterorganisatie van CMI, 'International Career Consulting Institute' (ICCI), werkt bijvoorbeeld met drie niveaus naar gelang de ervaring van de te certificeren adviseurs. Deze zijn anders dan de drie niveaus bij CMI, waarbij uitgegaan wordt van de breedte van het werkveld. (Voor het proces van certificering zie de CMIwebsite: www.cminl.nl en de inleiding van dit hoofdstuk.)

\subsubsection{Steekproef}

De totale steekproef betrof 170 casusvoorbeelden. In de steekproef waren vrouwen in de meerderheid, te weten: 130 van de 170 loopbaanadviseurs; dat is $77 \%$. Dit illustreert dat het vakgebied kennelijk meer aantrekkingskracht heeft op vrouwen dan op mannen: Leeftijd: de gemiddelde leeftijd van de 170 loopbaanadviseurs, die aan de steekproef deelnamen, was 51 jaar $(S D=6,3)$. Alle 170 loopbaanadviseurs hadden een hbo- $(74 \%)$ of wo- $(26 \%)$ opleiding, maar niet noodzakelijkerwijs een hbo- of wo-opleiding in loopbaanadvisering. De gemiddelde algemene werkervaring was 25,7 jaar, met een $S D$ van 7,9 jaar. De gemiddelde specifieke werkervaring was 11,2 jaar, met een $S D$ van 4,8 jaar.

Zoals in paragraaf 4.2.1 reeds werd aangegeven, onderscheidt CMI drie niveaus van vakbekwaamheid, naargelang de kandidaat meer in de breedte van het vakgebied werkt. Het A-niveau van dit onderzoek bestond uit 30 loopbaanadviseurs $(17,6 \%)$; het B-niveau uit 100 loopbaanadviseurs (58,8\%) en het C-niveau uit 40 loopbaanadviseurs $(23,5 \%)$. 


\subsubsection{Meetinstrumenten}

Het eigen ontwikkelmodel in analogie met het ontwikkelmodel van Kohlberg. In de wetenschappelijke literatuur over ethiek schreef Kohlberg (1958) een dissertatie over ethische ontwikkelstadia. Kohlberg gebruikt in zijn proefschrift 'The development of modes of moral thinking and choice in the years $10-16^{\prime}$ casusvoorbeelden om de ethische ontwikkelstadia bij jongens van tien tot zestien jaar oud vast te kunnen stellen. Hij deelt de casusvoorbeelden in drie hoofdstadia en zes onderliggende ontwikkelstadia in. Hij vraagt zich vervolgens af in hoeverre de moraliteit van de jongens kan worden gezien als een algemene dimensie van sociale ontwikkeling. De zes ontwikkelstadia bij Kohlberg volgen elkaar op in een ontwikkelhiërarchie:

- Ethische ontwikkelstadium 0: oriëntatie op gehoorzaamheid (voorkomen van straf).

- Ethische ontwikkelstadium 1: oriëntatie op eigen belang (wat levert het mij op).

- Ethische ontwikkelstadium 2: oriëntatie op conformiteit (de keurige jongeman mentaliteit).

- Ethische ontwikkelstadium 3: oriëntatie op autoriteit (law and order mentaliteit).

- Ethische ontwikkelstadium 4: oriëntatie op sociale ethische contracten.

- Ethische ontwikkelstadium 5: oriëntatie op universele ethische principes.

In het voor het huidige onderzoek ontwikkelde model wordt de mate van ethische ontwikkeling van de loopbaanadviseurs onderzocht door middel van 170 casusvoorbeelden inzake het ethisch dilemma. Dit onderzoek richt zich op de ethische ontwikkelstadia van de door CMI te certificeren loopbaanadviseurs. In het dossier voor certificering stelt CMI de volgende vraag: "In het casusvoorbeeld dient een ethisch dilemma te worden beschreven binnen de driehoeksrelatie tussen opdrachtgever, 
cliënt en loopbaanadviseur" Evenals in het model van Kohlberg worden de ontwikkelstadia in het huidige onderzoek vastgesteld op basis van de ethische oordeelsvorming. (Zie paragraaf 4.1 voor de vijf ontwikkelstadia.)

Beoordeling door morele oordeelsvorming van de beoordelende experts.

Gezien de verschillende belangen binnen het spanningsveld van adviseur, cliënt en opdrachtgever ontstaan er voor de adviseur tijdens het begeleiden van een cliënt steeds dilemma's, maar niet noodzakelijkerwijs ethische dilemma's. In het huidige onderzoek werd de ethische oordeelsvorming door zeven loopbaanadviesexperts verricht. De casusvoorbeelden werden beoordeeld en gecategoriseerd in vijf ontwikkelstadia van ethisch handelen door drie groepen van telkens drie personen, steeds met de auteur van deze studie als linking pin. Alle beoordelende experts zijn mentor of bestuurslid van CMI. Zes van de zeven, inclusief de auteur van dit proefschrift, waren zelf ook door CMI gecertificeerd en zijn of waren mentoren van CMI. Eén vertegenwoordigt, als HR-directeur, de werkgevers/opdrachtgevers in het CMI-bestuur.

De opdracht aan de zeven beoordelende experts was om ieder een derde van de 170 casusvoorbeelden van ethische dilemma's te scoren in het spanningsveld van de adviseur met de cliënt en de opdrachtgever. De opdracht luidde als volgt: "De bedoeling is om deze voorbeelden te beoordelen vanuit het spanningsveld van de bekende loopbaandriehoek van adviseur cliënt en opdrachtgever. Daarbij kan een keuze gemaakt worden tussen de onderstaande vijf niveaus van ethisch handelen." (Zie paragraaf 4.1 voor de vijf ontwikkelstadia.) De genoemde drie groepen namen derhalve ieder een derde van de casusvoorbeelden voor hun rekening. Dus tweemaal 57 voorbeelden en eenmaal 56 voorbeelden. $\mathrm{Zij}$ werden gevraagd om de aan hun toebedeelde casus- 
voorbeelden te scoren door een keuze te maken voor één van de bovenstaande vijf ontwikkelstadia per casusvoorbeeld.

Er wordt gesproken van consensus als minimaal twee van de drie experts dezelfde keuze maken. Als de drie experts geen consensus bereiken valt het casusvoorbeeld af voor een positieve beoordeling van het ethische dilemma. In de ontwikkelstadia 1 en 2 is er nog geen sprake van de herkenning van een dilemma. Daarom worden deze casusvoorbeelden niet meegeteld als een goed voorbeeld van een dilemma, laat staan een ethisch dilemma. Ook de casusvoorbeelden die geplaatst worden in ethisch ontwikkelstadium 3 vallen af. Deze casusvoorbeelden werden in ethisch ontwikkelstadium 3 geplaatst omdat er consensus was over de vaststelling dat het casusvoorbeeld gaat over een dilemma, maar niet gaat over een ethisch dilemma. Een score 4 wordt gegeven als de experts vinden dat het casusvoorbeeld een ethisch dilemma correct heeft beschreven. Als het casusvoorbeeld correct beschreven en als het dilemma bovendien goed opgelost is, wordt het casusvoorbeeld in het ethische ontwikkelstadium 5 geplaatst.

Ook in het geval een casusvoorbeeld door een expert in stadium 4 en door een andere expert in stadium 5 geplaatst werd, is dit gedefinieerd als consensus. De reden hiervan is dat ethisch ontwikkelstadium 5 vanzelfsprekend ethisch ontwikkelstadium 4 impliceert en ethisch ontwikkelstadium 4 voldoet aan het criterium dat er een ethisch dilemma beschreven wordt. In het onderhavige onderzoek komt deze vorm van consensus achtmaal voor.

De morele oordeelsvorming wordt primair bereikt door een proces van redenatie en reflectie. Daarbij ontstaat steeds een dilemma als er gekozen moet worden tussen twee ontwikkelstadia. Alhoewel de beoordelaars het vaak zelf een dilemma vonden (Elliot, 2011) om tussen twee ontwikkelstadia te kiezen, is het resultaat zeker bevredigend. Dat er slechts 76 maal een correct casusvoorbeeld met 
consensus gescoord kon worden (dus een score van een ethisch dilemma in ethisch ontwikkelstadium 4 of 5), kan niet op het conto van de zeven beoordelende experts geschreven worden. Voor hen waren de mate van kwaliteit van de casusvoorbeelden een gegeven.

\subsection{Resultaten}

Hieronder worden de resultaten van het huidige onderzoek besproken, om daarmee een antwoord te geven op de drie kernvragen.

Kernvraag 1 luidde: Heeft de loopbaanadviseur voldoende ethisch besef ontwikkeld om aan de eis te voldoen om ethisch te kunnen handelen? Zoals Tabel 4.1 aangeeft, waren er van de 170 casusvoorbeelden 32 voorbeelden die door alle drie beoordelende experts gelijk gescoord (19\%) werden. 107 maal werd een voorbeeld door twee van de drie beoordelende experts gelijk gescoord (63\%). In 31 gevallen werd geen consensus bereikt, doordat door de drie experts niet gelijk gescoord werd (18\%). Daarvan werd achtmaal één keer ethisch ontwikkelstadium 4 (ethisch dilemma) en één keer ethisch ontwikkelstadium 5 (ethisch dilemma; goed opgelost) gescoord. Omdat deze acht scores tweemaal een ethisch dilemma aangeven, worden deze acht scores goed gerekend als correct gescoorde voorbeelden van het ethische dilemma met consensus; zij zijn derhalve in ethisch ontwikkelstadium 4 geplaatst. De 23 andere scores betroffen uitkomsten zonder consensus. In totaal scoorden 139 (82\%) casusvoorbeelden twee- of driemaal gelijk. Inclusief de genoemde acht casusvoorbeelden zonder consensus, die eenmaal stadium 4 en éénmaal stadium 5 scoorden, is de totaalscore met consensus 147 (87\%). 
Tabel 4.1

Overzicht van met consensus beoordeelde scores per ethisch ontwikkelstadium.

\begin{tabular}{lccc}
\hline Stadium & Driemaal gelijk & Tweemaal gelijk & Aantal gelijke scores \\
\hline Stadium 1 & 0 & 10 & 10 \\
Stadium 2 & 6 & 45 & 51 \\
Stadium 3 & 1 & 9 & 10 \\
Stadium 4 & 3 & 17 & 20 \\
Stadium 5 & 22 & 26 & 48 \\
\hline Subtotaal & 32 & 107 & 139 \\
& $(19 \%)$ & $(63 \%)$ & $(82 \%)$ \\
\hline Extra 'gelijke score' 4 \& 5 & 0 & 8 & 147 \\
\hline Totaal & 32 & 115 & $(87 \%)$ \\
\hline
\end{tabular}

Tabel 4.2 geeft een overzicht van de gelijke scores (consensus) per ethisch ontwikkelstadium per beoordelende expertgroep. Hoewel blijkt dat de correcte scores (ontwikkelstadia 4 en 5) vrijwel gelijk verdeeld zijn over de drie groepen, treden er meer verschillen op als alle ontwikkelstadia in de beschouwing meegenomen worden. Groep 1 scoorde 43 maal (75\%) met consensus en groep 2 scoorde 55 maal (97\%) met consensus. Groep 3 scoorde 41 maal (73\%) met consensus.

Het aantal in ethisch ontwikkelstadium 4 of 5 geplaatste kandidaten bleek nauwelijks te verschillen tussen de drie groepen experts: 25 maal voor groep 1 en groep 2 en 26 maal voor groep 3. Dit is opvallend, omdat de consensusresultaten van de drie groepen onderling nogal verschillen. Het beste consensusresultaat werd geleverd door groep 2, die 55 maal consensus scoorde van de 56 casusvoorbeelden. Het minst goede scoringsresultaat werd geleverd door groep 3, die 41 maal consensus scoorde, terwijl groep 143 maal met consensus scoorde. 
Tabel 4.2

Overzicht van met consensus beoordeelde voorbeelden per ethisch ontwikkelstadium per groep.

\begin{tabular}{lcccc}
\hline Stadium & Groep 1 & Groep 2 & Groep 3 & Totaal \\
\hline Gelijke scores stadia & 57 & 57 & 56 & 170 \\
4 en 5 & 8 & & & \\
3 maal gelijk 5 & 1 & 10 & 4 & 22 \\
3 maal gelijk 4 & 9 & 2 & 0 & 3 \\
2 maal gelijk 5 & 3 & 6 & 14 & 26 \\
2 maal gelijk 4 & 4 & 6 & 3 & 17 \\
1 maal 4 en 1 maal 5 & 25 & 25 & 26 & 8 \\
\hline Totaal 'correcte' scores & $(15 \%)$ & $(15 \%)$ & $(15 \%)$ & $(44,7 \%)$ \\
\hline
\end{tabular}

Gelijke scores

\begin{tabular}{lcccc}
\hline Totaal 3 maal gelijk & 12 & 16 & 4 & 32 \\
\hline Totaal 2 maal gelijk & 31 & 39 & 37 & 107 \\
\hline Subtotaal gelijke score & 43 & 55 & 41 & 139 \\
& $(75 \%)$ & $(97 \%)$ & $(73 \%)$ & $(82 \%)$ \\
\hline 1 maal 4 en 1 maal 5 & 4 & 1 & 3 & 8 \\
\hline Totaal gelijke score & 47 & 56 & 44 & 147 \\
& $(83 \%)$ & $(98 \%)$ & $(79 \%)$ & $(87 \%)$ \\
\hline Geen gelijke score & 10 & 1 & 12 & 23 \\
\hline
\end{tabular}

Kortom, in het spanningsveld werd van de 170 casusvoorbeelden 76 maal een casus met consensus correct gescoord als ethisch dilemma, terwijl 71 maal een casus met consensus gescoord werd zonder deze als ethisch dilemma te kwalificeren. 23 maal werd een casus zonder consensus gescoord. 
Dat betekent dat 55,3\% van de loopbaanadviseurs in de steekproef geen ethisch dilemma beschrijft, terwijl $44,7 \%$ van hen een correct casusvoorbeeld beschrijft, al dan niet met een goede oplossing voor het ethische dilemma. Kernvraag 1 wordt derhalve als volgt beantwoord: Loopbaanadvisering heeft over het algemeen nog onvoldoende ethisch besef ontwikkeld om aan de eis te voldoen om ethisch te kunnen handelen.

Kernvraag 2 luidde: Is er een relatie tussen het ethische ontwikkelstadium van de loopbaanadviseur en diens CMI-niveau? Uitgaande van alle 170 casusvoorbeelden is de correlatie tussen het ethische ontwikkelstadium van een loopbaanadviseur en diens certificeringsniveau marginaal significant (Spearman's rho $=0,14, p=0,079)$. Ook bij alle 147 casusvoorbeelden waarover consensus bestaat tussen minimaal twee experts is er sprake van marginaal significante correlatie: rho $=0,15 ; p=0,063$. Bij 76 casusvoorbeelden met een ethisch dilemma (dus stadium 4 of 5) waarover consensus bestaat tussen minimaal twee experts, is er echter sprake van een significante positieve correlatie tussen het ethisch ontwikkelstadium van de te certificeren adviseur en diens CMI-niveau, namelijk: rho $=0,24 ; p<0,05$. Dit betekent dat er een positief verband bestaat tussen het ethische ontwikkelstadium van een loopbaanadviseur en diens certificeringsniveau, namelijk: hoe breder het CMIniveau van een adviseur, hoe 'hoger' diens ethische ontwikkelstadium is.

Tabel 4.3 laat zien dat er tussen de drie niveaus aanzienlijke verschillen in het aantal correcte scores met consensus zijn inzake de ontwikkelstadia 4 en 5 :

- CMI-niveau A: 11 van in totaal 30 casusvoorbeelden. Dit is 36,6\%.

- CMI-niveau B: 45 van in totaal 100 casusvoorbeelden. Dit is $45 \%$.

- CMI-niveau C: 20 van in totaal 40 casusvoorbeelden. Dit is 50\%.

Dit geeft aan dat de loopbaanadviseurs op het breedste CMI-niveau (C) beter scoorden op de ontwikkelstadia 4 en 5 dan loopbaanadviseurs op het minder brede 
niveau (B) en het minder brede niveau beter dan smalste niveau (A). Dat wil zeggen dat er inderdaad een ontwikkelhiërarchie blijkt te zijn tussen de drie CMI-niveaus. Kernvraag 2 kan daarom positief worden beantwoord: er is een relatie tussen het ethische ontwikkelstadium van de loopbaanadviseur en diens CMI-niveau

Kernvraag 3 luidde: Is er een relatie tussen de achtergrondvariabelen (leeftijd, gender, opleiding, en algemene en specifieke werkervaring) van de loopbaanadviseur en diens ethische ontwikkelstadium en CMI-niveau?

Gender: Uit de Spearman's correlatieanalyses bleek dat gender van de adviseur niet correleert met diens ethisch ontwikkelstadium ( $r h o=-0,11 ; p=0,141)$. Gender (gecodeerd als man $=0$ en vrouw $=1$ ) bleek echter wel marginaal significant negatief samen te hangen met het CMI-niveau: $r h o=-0,15 ; p=0,053$. Dat wil zeggen dat mannelijke adviseurs in dit onderzoek in het algemeen op een iets hoger niveau gecertificeerd waren dan de vrouwelijke adviseurs.

Leeftijd: Uit de Spearman's correlatieanalyses bleek dat de leeftijd van de adviseur niet samenhangt met diens ethisch ontwikkelstadium (Spearman's rho $=0,10 ; p$ $=0,182$ ). Daarentegen toonde het onderzoek wel aan dat leeftijd positief samenhangt met CMI-niveau van de adviseur: rho $=0,21(p<0,01)$. Adviseurs op CMI-niveau C waren gemiddeld vier jaar ouder dan adviseurs op CMI-niveau A en drie jaar ouder dan adviseurs op CMI-niveau B. Dat wil zeggen dat hoe ouder een adviseur is hoe breder zijn CMI-niveau doorgaans is. 
Tabel 4.3

De mate van consensus van 170 casusvoorbeelden verbijzonderd naar de CMI-niveaus A, B en C.

\begin{tabular}{|c|c|c|c|c|}
\hline Stadium & $\begin{array}{c}\text { Niveau A } \\
(N=30)\end{array}$ & $\begin{array}{l}\text { Niveau B } \\
(N=100)\end{array}$ & $\begin{array}{c}\text { Niveau C } \\
(N=40)\end{array}$ & $\begin{array}{c}\text { Totaal } \\
(N=170)\end{array}$ \\
\hline Geen consensus & 5 & 13 & 5 & 23 \\
\hline Stadium 1: 2 x 1 & 1 & 8 & 1 & 10 \\
\hline Stadium 1: $3 \times 1$ & 0 & 0 & 0 & 0 \\
\hline Stadium 2: $2 \times 2$ & 11 & 25 & 9 & 45 \\
\hline Stadium 2: $3 \times 2$ & 0 & 3 & 3 & 6 \\
\hline Stadium 3: $2 \times 3$ & 2 & 6 & 1 & 9 \\
\hline Stadium 3: $3 \times 3$ & 0 & 0 & 1 & 1 \\
\hline $\begin{array}{l}\text { Stadia zonder ethisch } \\
\text { dilemma }\end{array}$ & 19 & 55 & 20 & 94 \\
\hline $\begin{array}{l}\text { Totaal niveau } \\
\text { certificering }\end{array}$ & 30 & 100 & 40 & 170 \\
\hline in $\%$ & $63 \%$ & $55 \%$ & $50 \%$ & $55,3 \%$ \\
\hline Stadium 4: $2 \times 4$ & 4 & 11 & 2 & 17 \\
\hline Stadium 4: $3 \times 4$ & 1 & 2 & 0 & 3 \\
\hline Stadium 5: $2 \times 5$ & 4 & 15 & 7 & 26 \\
\hline Stadium 5: $3 \times 5$ & 2 & 11 & 9 & 22 \\
\hline Stadium een maal 4 en 5 & 0 & 6 & 2 & 8 \\
\hline $\begin{array}{l}\text { Stadia met ethisch } \\
\text { dilemma per niveau }\end{array}$ & 11 & 45 & 20 & 76 \\
\hline $\begin{array}{l}\text { Totaal niveau } \\
\text { certificering }\end{array}$ & 30 & 100 & 40 & 170 \\
\hline In \% & $36,6 \%$ & $45 \%$ & $50 \%$ & $44,7 \%$ \\
\hline
\end{tabular}


Opleidingsniveau: Het opleidingsniveau van de adviseurs correleert niet met de ontwikkelstadia $($ rho $=-0,119 ; p=0,121)$. Het opleidingsniveau correleert ook niet met het CMI-niveau (rho $=-0,026 ; \mathrm{p}=0,734$ ). Van de steekproef hadden 45 loopbaanadviseurs een wo-opleiding gevolgd, waarvan er 12 op CMI-niveau C werden gecertificeerd, 25 op CMI-niveau B en 8 op CMI-niveau A. Van de 125 loopbaanadviseurs die een hbo-opleiding hebben gevolgd, functioneren er 22 op A-niveau, 75 op B-niveau en 28 op C-niveau. Alle 170 loopbaanadviseurs hadden echter wel een additionele opleiding als loopbaanadviseur gevolgd. In de onderzoeksperiode (2012-2014) bestond er op wo-niveau nog geen loopbaanadviesopleiding, waardoor iedere voltooide wetenschappelijke of hbo-opleiding voldoende was om te kwalificeren als kandidaat voor CMI-certificering. In de onderzoeksperiode hadden vijf adviseurs reeds het diploma van een loopbaanopleiding op hbo-niveau behaald.

Tabel 4.4 geeft een overzicht van de opleidingsachtergrond van de 45 woopgeleide loopbaanadviseurs. Een opleiding psychologie blijkt voor bijna een derde van de wo-opgeleide loopbaanadviseurs in dit onderzoek de vooropleiding te zijn.

Algemene werkervaring: Uit de correlatieanalyses bleek dat algemene werkervaring van de adviseur positief correleert met het CMI-niveau: rho $=0,25 ; p$ $<0,001$. Dat wil zeggen: hoe meer algemene werkervaring een adviseur heeft, hoe 'breder' hij of zij gecertificeerd is. Loopbaanadviseurs op CMI-niveau C hebben gemiddeld vijf en vier jaar meer algemene werkervaring dan adviseurs op Arespectievelijk B-niveau. Daarentegen correleert de algemene werkervaring van de adviseur niet met het ethische ontwikkelstadium $(r h o=0,03 ; p=0,671)$. Tabel 4.5 laat zien dat CMI C-niveau adviseurs gemiddeld meer algemene werkervaring hebben dan degenen op CMI-niveau A en B (29 jaar ten opzichte van 25 jaar voor niveau B en 24 jaar voor niveau A). 
Tabel 4.4

Opleidingsachtergrond wo-opgeleide loopbaanadviseurs.

\begin{tabular}{lccc}
\hline \multicolumn{1}{c}{ Discipline } & Aantal & Vrouw & Man \\
\hline Psychologie & 13 & 11 & 2 \\
Communicatie & 5 & 5 & 0 \\
Letteren & 5 & 4 & 1 \\
Rechten & 5 & 4 & 1 \\
Politicologie & 4 & 2 & 2 \\
Economie & 3 & 2 & 1 \\
Sociologie & 2 & 2 & 0 \\
Diversen & 8 & 7 & 1 \\
\hline \multicolumn{1}{c}{ Total } & 45 & 37 & $(18 \%)$ \\
\hline
\end{tabular}

Specifieke werkervaring: In tegenstelling tot de algemene werkervaring van een adviseur bleek specifieke werkervaring wel marginaal te correleren met diens ethische ontwikkelstadium: $r h o=0,14 ; p=0,072$. Daarnaast bleek specifieke werkervaring, evenals algemene werkervaring, positief samen te hangen met het CMIniveau, namelijk: $r h o=0,35, p<0,001$. Dat wil zeggen dat hoe meer specifieke werkervaring een adviseur heeft, hoe 'breder' hij of zij gecertificeerd is.

Tabel 4.5 laat tevens zien dat CMI-niveau C-adviseurs gemiddeld ook meer specifieke werkervaring hebben in het vakgebied: 13 jaar ten opzichte van 7 jaar op A-niveau en 12 jaar op B-niveau. Uit het verschil tussen de algemene ervaring en de specifieke ervaring van de loopbaanadviseur blijkt dat de loopbaanadviseur gemiddeld 13 tot 17 jaar ander werk heeft verricht, voordat men in het loopbaanadvies vak is gaan werken. 
Tabel 4.5

Gemiddelde specifieke en algemene werkervaring per peildatum 1 juli 2014.

\begin{tabular}{lccc}
\hline CMI-Niveau & Aantal adviseurs & $\begin{array}{c}\text { Algemene } \\
\text { werkervaring }\end{array}$ & $\begin{array}{c}\text { Specifieke } \\
\text { werkervaring }\end{array}$ \\
\hline A-niveau & 30 & 24 jaar & 7 jaar \\
B-niveau & 100 & 25 jaar & 12 jaar \\
C-niveau & 40 & 29 jaar & 13 jaar \\
\hline Totaal & 170 & 26 jaar & 12 jaar \\
\hline
\end{tabular}

Bredere oriëntatie op het vakgebied ( $N=170)$ : Voor de vaststelling van het niveau van de certificering oriënteert CMI zich bij de toetsing op twee aspecten: de breedte van het werkgebied en het aantal jaren van specifieke ervaring. Voor wat betreft de breedte van het werkgebied moet de kandidaat om op CMI C-niveau gecertificeerd te kunnen worden, aantonen zowel cliënten te kunnen begeleiden als ervaring te hebben met opdrachtgevers, alsook beleidsadviezen te kunnen geven aan organisaties op het terrein van loopbaanadvisering.

Daarnaast dient de kandidaat voor CMI C-niveau zes jaar specifieke loopbaanervaring aan te kunnen tonen. De loopbaanadviseurs die op CMI A en B-niveau gecertificeerd zijn moeten respectievelijk drie en vijf jaar specifieke werkervaring aan kunnen tonen. Tabel 4.5 laat zien dat het gemiddelde aantal jaren specifieke werkervaring van de kandidaten veel hoger ligt dan deze ondergrenzen: CMI Cniveau kandidaten voor certificering hebben gemiddeld dertien jaar specifieke werkervaring, terwijl de kandidaten op B en A-niveau respectievelijk 12 en 7 jaar specifieke werkervaring hebben. Het gemiddelde aantal jaren algemene werkervaring ligt op alle drie niveaus nog veel hoger. 
Tabel 4.6 geeft een overzicht van de achtergrondvariabelen van de kandidaten op CMI A-, B- en C-niveau. Opmerkelijk is het relatief hoge percentage vrouwen op niveau $\mathrm{B}$ en het relatief hoge percentage mannen op niveau $\mathrm{C}$.

Tabel 4.6

Overzicht achtergrondvariabelen van 170 RL's, verdeeld over CMI-niveaus A, B en C.

\begin{tabular}{|c|c|c|c|c|c|}
\hline CMI-niveau & $N$ & Man / vrouw & $\begin{array}{l}\text { Gemiddelde } \\
\text { geboortejaar }\end{array}$ & wo / hbo & $\begin{array}{l}\text { Einde LB- } \\
\text { opleiding }\end{array}$ \\
\hline \multirow[t]{2}{*}{$\mathrm{A}$} & 30 & $7 \mathrm{~m}$ & 1965 & 8 wo & 2005 \\
\hline & & $23 \mathrm{v}$ & & 22 hbo & \\
\hline \multirow[t]{2}{*}{ B } & 100 & $17 \mathrm{~m}$ & 1964 & 25 wo & 2003 \\
\hline & & $83 \mathrm{v}$ & & 75 hbo & \\
\hline \multirow[t]{2}{*}{ C } & 40 & $16 \mathrm{~m}$ & 1961 & 12 wo & 2000 \\
\hline & & $24 \mathrm{v}$ & & $28 \mathrm{hbo}$ & \\
\hline \multirow[t]{2}{*}{ Totaal } & 170 & $40 \mathrm{~m}$ & 1963 & 45 wo & 2003 \\
\hline & & $130 \mathrm{v}$ & & $125 \mathrm{hbo}$ & \\
\hline
\end{tabular}

\subsection{Discussie}

\subsubsection{Bevindingen van het onderzoek}

In de inleiding van dit hoofdstuk werd gesteld dat zonder een basis van vertrouwen tussen de cliënt en de loopbaanadviseur, er geen sprake kan zijn effectieve begeleiding. Zonder ethisch te handelen kan een loopbaanadviseur dat vertrouwen niet opbouwen, waardoor de loopbaanadviseur het vak niet of onvoldoende adequaat kan uitoefenen. Ethiek en het daaruit voortvloeiend ethisch besef en ethisch handelen zijn derhalve hoekstenen voor het vakgebied. De onderstaande conclusies geven inzicht in de mate waarin ethisch besef en ethisch handelen 
bij de loopbaanadviseur aanwezig zijn en geven ook inzicht in de relatie tussen het ethisch besef en het CMI-niveau alsook de achtergrondkenmerken van de te certificeren kandidaten.

Kernvraag 1 luidde: Heeft de loopbaanadviseur voldoende ethisch besef ontwikkeld om aan de eis van CMI te voldoen om ethisch te kunnen handelen? In de inleiding van dit hoofdstuk werd de vraag gesteld of en in hoeverre het vakgebied zich ontwikkeld heeft, waardoor de te certificeren loopbaanadviseurs voldoende ethisch besef opgebouwd hebben om ethisch te kunnen handelen en daardoor het vak naar behoren te kunnen uitvoeren. Het blijkt echter dat slechts minder dan de helft van de loopbaanadviseurs $(44,7 \%)^{11}$ heeft laten zien voldoende ethisch besef te hebben opgebouwd, door een correct voorbeeld te geven van een ethisch dilemma.

Dat meer dan de helft van de 170 te certificeren loopbaanadviseurs het ethisch dilemma niet goed beschreven heeft, zou kunnen liggen aan het feit dat de opdracht onvoldoende duidelijk is gesteld. Dat is echter onwaarschijnlijk. De opdracht luidt: "In het casusvoorbeeld dient een ethisch dilemma te worden beschreven binnen de driehoeksrelatie tussen opdrachtgever, cliënt en loopbaanadviseur". Er kan derhalve over de duidelijkheid van de CMI-opdracht geen verschil van mening bestaan.

Hoewel er ook van uitgegaan mag worden dat de loopbaanadviseurs zich, door de aangetoonde vakbekwaamheid, mogen rekenen tot de uitgelezen groep van vakgenoten, zou het kunnen zijn dat de loopbaanadviseurs door hun relatief korte specifieke ervaring in het vakgebied, een ethisch dilemma niet in voldoende mate onderkennen, waardoor er gemiddeld relatief laag gescoord wordt. Kernvraag 1

\footnotetext{
${ }^{11}$ ISO-certificering schrijft voor dat alle vragen die aan de kandidaten voor certificering gesteld worden ofwel direct in het dossier, ofwel na een toelichting tijdens de toetsing, met minimaal voldoende moeten worden beoordeeld. Blijkbaar zijn tijdens de toetsing door de toelichting nogal wat casusvoorbeelden alsnog goedgekeurd.
} 
wordt derhalve als volgt beantwoord: Loopbaanadvisering heeft over het algemeen nog te weinig ethisch besef ontwikkeld om aan de eis van CMI te voldoen om ethisch te kunnen handelen.

Kernvraag 2 luidde: Is er een relatie tussen het ethische ontwikkelstadium van de te certificeren loopbaanadviseur en diens CMI-niveau? Uit de analyses blijkt dat als alle casusvoorbeelden $(N=170)$ meegenomen worden het ethisch ontwikkelstadium van de te certificeren loopbaanadviseur slechts marginaal significant gerelateerd is aan diens CMI-niveau. Dit is eveneens het geval als alleen de casusvoorbeelden met consensus worden $(N=147)$ onderzocht.

Als er alleen wordt gekeken naar de correcte casusvoorbeelden (d.w.z. stadium 4 of 5) waarover consensus bestaat $(N=76)$, dan blijkt er echter wel een significante positieve correlatie te bestaan tussen het CMI-niveau van de loopbaanadviseur en diens ethische ontwikkelstadium. Het blijkt dat $50 \%$ van de door de op CMI C-niveau gecertificeerde adviseurs beschreven casusvoorbeelden een correct antwoord geeft op de gestelde vraag, tegenover $45 \%$ van loopbaanadviseurs op het CMI B-niveau en slechts 36,6\% op het CMI A-niveau. Geconstateerd wordt derhalve dat er een ontwikkelhiërarchie bestaat in de mate waarin men een ethisch dilemma herkent. Dit bevestigt het positieve verband tussen het ethisch ontwikkelingsstadium van een loopbaanadviseur en het certificeringsniveau. Kernvraag 2 kan derhalve bevestigend beantwoord worden: er is een relatie tussen het ethische ontwikkelstadium van de te certificeren loopbaanadviseur en diens CMI-niveau.

Kernvraag 3 luidde: Is er een relatie tussen de achtergrondvariabelen (leeftijd, gender, opleiding, en algemene en specifieke werkervaring) van de loopbaanadviseur en diens ethisch ontwikkelingsstadium en CMI-niveau? Uit het onderzoek blijkt gender niet samen te hangen met ethisch ontwikkelstadium en slechts 
marginaal met CMI-niveau. Ook de leeftijd van een loopbaanadviseur is niet gerelateerd aan diens ethisch ontwikkelingsstadium, maar wel aan diens CMIniveau. De opleiding die een adviseur genoten heeft bleek noch met diens ethisch ontwikkelingsstadium noch met diens CMI-niveau samen te hangen. Resumerend: het ethisch ontwikkelingsstadium van een loopbaanadviseur hangt niet samen met diens gender, leeftijd noch opleiding en het CMI-niveau van een adviseur hangt alleen samen met diens leeftijd. In het algemeen geldt dus: hoe ouder een adviseur, hoe breder diens werkterrein.

Daarnaast bleek de algemene werkervaring van een loopbaanadviseur niet te correleren met diens ethisch ontwikkelingsstadium en de specifieke werkervaring slechts marginaal. Wel bleken zowel de algemene als de specifieke werkervaring van de loopbaanadviseur positief samen te hangen met diens CMI-niveau. Dat wil zeggen, hoe meer algemene- en specifieke werkervaring, hoe breder het werkterrein.

Uit het verschil tussen de algemene ervaring en de specifieke ervaring van de loopbaanadviseur blijkt dat de loopbaanadviseur gemiddeld 13 tot 17 jaar ander werk heeft verricht, voordat er voor het loopbaanvak gekozen wordt. Mogelijk wordt een zekere levenservaring ${ }^{12}$ als noodzaak gevoeld om loopbaanadviseur te worden, vaak dus als tweede carrière. Het blijkt echter niet te leiden tot een hoger ethisch ontwikkelingsstadium. Kernvraag 3 kan voor wat het ethisch besef van de loopbaanadviseurs deels niet bevestigend beantwoord worden: er is geen relatie tussen de achtergrondvariabelen van de loopbaanadviseur met diens ethisch ontwikkelstadium, maar wel tussen de achtergrondvariabelen leeftijd alsmede specifieke werkervaring en CMI-niveau.

\footnotetext{
${ }^{12}$ Of levenservaring bijdraagt aan de kwaliteit van de loopbaanadviezen valt buiten de reikwijdte van dit hoofdstuk.
} 


\section{Conclusies}

Het CMI-niveau en het ethische ontwikkelniveau van de loopbaanadviseur correleren, maar minder sterk dan verwacht. Bovendien heeft slechts $44,7 \%$ van de adviseurs de opdracht om een ethisch dilemma te beschrijven correct uitgevoerd. Het zou kunnen zijn dat een aantal van de onderzochte loopbaanadviseurs, in de gemiddeld 12 jaar dat zij hun vak uitoefenen, nog nimmer een ethisch dilemma in hun praktijk is tegengekomen. Dat is echter onwaarschijnlijk. De praktijk wijst uit dat ethische dilemma's veelvuldig voorkomen.

Waarschijnlijker is dat de loopbaanadviseurs het ethisch dilemma nog onvoldoende onderkennen, waardoor ze er niet of onvoldoende op reageren. Meer jaren specifieke ervaring zou dan mogelijk de oplossing kunnen bieden om tot meer herkenning van het ethisch dilemma te geraken. Zoals het statistisch onderzoek laat zien, zou langere specifieke ervaring als loopbaanadviseur, op basis waarvan iemand op C-niveau zou kunnen worden gecertificeerd, ertoe kunnen leiden dat er meer correcte voorbeelden gescoord worden. Het zou derhalve een kwestie van tijd kunnen zijn, om in dit jonge vak gemiddeld een score van boven de $50 \%$ te bereiken.

\subsubsection{Beperkingen}

Zoals elk onderzoek kent ook het hierboven beschreven onderzoek beperkingen. Een belangrijke beperking van het huidige onderzoek betreft de veronderstelling dat het ethisch besef en in het verlengde daarvan het ethisch handelen voor iedere loopbaanadviseur op hetzelfde morele niveau ligt. Maar dat is niet noodzakelijkerwijs het geval. Zo zou de loopbaanadviseur door meer intuïtief gevoel (Haidt, 2001) of door een meer specifieke opleiding de ethische ontwikkelstadia wellicht sneller kunnen doorlopen. 
Betrouwbaarheid: Als het uitgangspunt geaccepteerd wordt dat casusvoorbeelden correct gescoord worden als minimaal twee van de drie experts een keuze met consensus maken, is 147 maal met consensus gescoord. Voor alle beoordelaars tezamen is de betrouwbaarheidscoëfficiënt Cronbach's alpha =0,62; alleen groep 2 scoort Cronbach's alpha $=0,74$. Dat is meer dan de vaak gehanteerde ondergrens voor Cronbach's alpha $>0,70$. Voor acht casusvoorbeelden betrof het echter consensus over scores in ethische ontwikkelstadium 4 en 5. Als deze acht scores niet als een correcte score worden beschouwd, zouden er 139 scores met consensus zijn en zou de Cronbach's alpha ook voor groep $2<0,70$ zijn.

Bij het scoren van de casusvoorbeelden van een ethisch dilemma werd door de zeven beoordelende experts over alle 170 casusvoorbeelden op zich voldoende consensus bereikt, namelijk 147 maal. Tijdens het onderzoek bleek echter dat één groep meer moeite had met het maken van keuzes dan de twee andere groepen, terwijl er over de expertise van alle beoordelaars geen twijfel bestaat. De beoordelaars van de genoemde groep zeiden moeite te hebben met de morele oordeelsvorming. De overige beoordelaars hebben zich hierover niet uitgesproken. Het maken van morele keuzes gaat echter steeds gepaard met een dilemma over de juiste keuze.

Validiteit: De interne validiteit is, evenals bij veel ander praktijkgericht onderzoek, laag. Alle 170 te certificeren loopbaanadviseurs die in de onderzoeksperiode een casusvoorbeeld schreven over een ethisch dilemma, schreven de casus op hun eigen wijze, op hun eigen moment en op hun eigen niveau, waardoor er ruis kan zijn ontstaan in het beoordelen van het ethisch ontwikkelingsstadium. Daarentegen is de externe validiteit hoog, omdat de 170 casusvoorbeelden door 'echte' loopbaanadviseurs zijn opgeschreven over ethische dilemma's, die zij ook zelf beleefd hebben. De context voor het onderzoek is derhalve authentiek. 


\subsubsection{Aanbevelingen}

Zoals reeds in de inleiding van dit hoofdstuk werd aangegeven, is ethiek de basis voor het handelen van de loopbaanadviseur. Als een cliënt het gevoel krijgt dat hij of zij de adviseur niet voldoende kan vertrouwen door een gebrek aan ethisch handelen, dan is het gedaan met de toch al broze relatie tussen cliënt en adviseur, waardoor verdere begeleiding weinig zinvol is. Een belangrijke aanbeveling die uit het onderhavige onderzoek volgt is derhalve dat er meer aandacht moet komen voor de ethische dilemma's die zich kunnen voordoen bij loopbaanbegeleiding. Het is van belang dat de loopbaanadviseur niet alleen gewezen wordt op zijn of haar kwetsbare positie in de beschreven driehoeksrelatie van adviseur, cliënt, en opdrachtgever, maar dat tijdens de opleiding van de adviseur ook ruime aandacht voor ethiek en ethisch handelen wordt uitgetrokken.

Bovendien verdient het aanbeveling dat de adviseur niet alleen tijdens de certificering, maar iedere drie jaar tijdens de re-certificering, getoetst wordt op zijn of haar ethisch handelen, waardoor de onderkenning van ethische dilemma's door loopbaanadviseurs zal groeien.

Voorts is in dit hoofdstuk aangetoond dat loopbaanadviseurs met een minder breed CMI-niveau gemiddeld minder goede casusvoorbeelden geven inzake een ethisch dilemma. Dit komt waarschijnlijk doordat loopbaanprofessionals met een minder brede ervaring de problematiek van ethische kwesties nog niet voldoende onderkennen of daarmee nauwelijks worden geconfronteerd. Derhalve is training en het opdoen van een brede ervaring belangrijk voor de ontwikkeling van het ethisch besef en het ethisch handelen van de loopbaanprofessional. Meer opleiding en training wordt van harte aanbevolen. 


\subsubsection{Tot slot}

Door de voortschrijdende professionalisering van het vakgebied en de gerichte loopbaanopleidingen zullen toekomstige loopbaanadviseurs naar verwachting steeds vaker direct na hun studie kiezen voor loopbaanadvisering in plaats van later in de loopbaan. Hierdoor zal op termijn de kloof tussen algemene en specifieke werkervaring afnemen. Uit het onderhavige onderzoek blijkt dat een ethisch dilemma beter beschreven en opgelost wordt naarmate de specifieke ervaring van de loopbaanadviseur toeneemt. Hierdoor zal men in de toekomst waarschijnlijk op jongere leeftijd beter in staat zijn om een ethisch dilemma te kunnen onderkennen en daardoor beter ethisch te handelen. De vraag in hoeverre een zekere levenservaring bijdraagt aan de kwaliteit van het werk de loopbaanadviseur valt echter buiten de reikwijdte van dit hoofdstuk. Maar het zou voor het vakgebied inzichtelijk zijn als er onderzoek naar dit onderwerp gedaan zou worden.

Hoewel in de huidige steekproef de opleiding niet gerelateerd blijkt te zijn aan het ethisch ontwikkel stadium en het CMI-niveau van de loopbaanadviseur, zou er mogelijk wel sprake kunnen zijn van een positieve relatie, als er niet wordt gekeken naar het opleidingsniveau maar naar de studierichting. Dit temeer daar steeds meer loopbaanadviseurs een hbo- of wo-loopbaanopleiding zullen hebben gevolgd. Zover is het echter nog niet. Maar met ethiek in het vakkenpakket van zowel de hbo- als de wo-opleiding tot loopbaanadviseur, mag verwacht worden dat dit bijdraagt aan de verdere ontwikkeling van het vakgebied tot een professie. 



\section{HOOFDSTUK 5 \\ SPECIFIEKE COMPETENTIES}

\subsection{Inleiding}

Stichting Career Management Institute (CMI), de Nederlandse certificerende instelling voor loopbaanadvisering, toetst kandidaten voor initiële certificering op vakbekwaamheid. In dit hoofdstuk wordt met name gefocust op de specifieke competenties, zoals deze door CMI zijn vastgesteld in het kader van het beroepsprofiel. CMI onderscheidt daarbij vijf basiscompetenties, ook wel 'grondhouding' genoemd, en vijf specifieke competenties. Van de basiscompetenties, zoals ethisch handelen ${ }^{1}$ en onafhankelijk handelen, heeft CMI geconstateerd dat alle kandidaten voor certificering deze competenties reeds beheersen, waardoor CMI deze competenties niet toetst.

Specifieke competenties zijn volgens CMI de competenties die de loopbaanadviseur primair nodig heeft om het vak uit te kunnen oefenen. Deze specifieke competenties worden aan de hand van vijf casusvoorbeelden door CMI getoetst in het kader van de certificering. Dit beleid is gebaseerd op de veronderstelling van CMI dat, als de primaire, specifiek voor het vakgebied door CMI benoemde competenties van de loopbaanadviseur van hoog kwaliteitsgehalte zijn, dit zeer bijdraagt aan een goede begeleiding van de cliënten naar een passende baan². Een

\footnotetext{
${ }^{1}$ Gezien de conclusie in het vorige hoofdstuk dat ethische dilemma's door loopbaanadviseurs over het algemeen nog onvoldoende adequaat behandeld worden, is het maar de vraag of CMI er verstandig aan doet om de basiscompetenties niet te toetsen.

${ }^{2}$ Loopbaanadvisering behoeft niet in alle gevallen te leiden tot een (nieuwe) baan. In sommige gevallen komt de cliënt tot de ontdekking dat hij of zij andere zaken in het leven belangrijker vindt dan een (nieuwe) baan, zoals bijvoorbeeld vrijwilligerswerk, maar ook prioriteit geven aan het gezin of aan een opleiding.
} 
onderzoek naar de ontwikkeling van de competenties die nodig zijn voor de begeleiding, is derhalve gericht op de mate waarin de te certificeren loopbaanadviseurs de vijf specifieke competenties hebben ontwikkeld.

\section{Basiscompetenties}

De vijf basiscompetenties die CMI onderscheidt zijn: ethisch handelen, onafhankelijk handelen, zelfreflectie, werken aan de eigen ontwikkeling en open staan voor andere denkbeelden. De basiscompetenties worden door CMI als volgt omschreven (zie ook www.cminl.nl):

1) Ethisch handelen: “CMI Register Loopbaanprofessionals (RL's) handelen conform ethische normen van de beroepsgroep. Dit betekent dat zij naar geweten zullen handelen, discretie toepassen en eerlijk naar cliënten en opdrachtgevers zullen optreden. RL's houden zich aan de gedragscode van CMI."

2) Onafhankelijk handelen: “CMI Register Loopbaanprofessionals (RL's) treden onafhankelijk op ten opzichte van belangen van alle betrokken partijen. Op basis van de waargenomen realiteit zullen zij oplossingen zoeken voor ontstane problemen of situaties zonder zich ten koste van één partij te gedragen."

3) Zelfreflectie: “CMI Register Loopbaanprofessionals (RL's) beschikken over het vermogen naar zichzelf te kijken. Ze zijn kritisch naar zichzelf om steeds duidelijk te kunnen zijn over de eigen positie. Ze vragen feedback en leren steeds bij over zichzelf. De RL's streven ernaar open en eerlijk op te treden in hun werk. Ze werken als professional en vanuit werk- en levenservaring op de wijze die bij hen past en vanuit hun kern en authenticiteit. Zij zijn zich daarbij bewust van eigen zwakke en sterke competenties." 
4) Werken aan de eigen ontwikkeling: "Register Loopbaanprofessionals (RL's) zijn steeds actief om zichzelf zo breed mogelijk te ontwikkelen. Primair voor de RL's is de ontwikkeling van het vakgebied."

5) Open staan voor andere denkbeelden: “De Register Loopbaanprofessional (RL) staat open voor andere denkbeelden. De RL's zullen collegae met andere denkbeelden consulteren, indien de RL dit nuttig acht in het kader van de begeleiding."

Deze competenties raken de wezenskenmerken van het zelfstandig handelen van de adviseur. De competenties werden door CMI als vanzelfsprekend voor het vakgebied beschouwd, waardoor CMI indertijd besloten heeft om deze competenties niet afzonderlijk te toetsen. Wel wordt aan de CMI-toetsingscommissie gevraagd mondeling te toetsen, indien er tijdens het toetsingsgesprek vraagtekens zijn over de toepassing van de basiscompetenties door de te certificeren loopbaanadviseur. Alle adviseurs die in het vakgebied werkzaam zijn, worden geacht deze basiscompetenties niet alleen te onderkennen maar ook te praktiseren.

\section{Specifieke competenties}

Naast deze basiscompetenties onderscheidt CMI vijf specifieke competenties die belangrijk zijn voor een goede begeleiding. Volgens CMI zijn dat: inlevingsvermogen, communicatieve vaardigheden, reflectie, advisering en coaching. Deze specifieke competenties worden als volgt omschreven (zie ook www.cminl.nl):

1) Inlevingsvermogen: "De loopbaanadviseur is in staat zich goed in te leven in mensen en situaties. Kan vanuit de situatie en opvattingen van anderen meedenken en oplossingen aandragen." 
2) Effectief communiceren: "De loopbaanadviseur is in staat ideeën, meningen en informatie over te dragen in duidelijke taal, gebaren en non-verbale communicatie. Reageert gepast en effectief op reacties, opmerkingen en gedrag van cliënten, opdrachtgevers en anderen. Behandelt klachten effectief."

3) Reflecteren: “De loopbaanadviseur spiegelt effectief verbaal en non-verbaal gedrag van cliënten, opdrachtgevers en anderen. Doet dit om bewustzijn van anderen te vergroten en ruimte te geven om te leren. Plaatst informatie van anderen in een groter kader en geeft hiermee ruimte voor verandering en leren."

4) Adviseren: "Loopbaanadviseurs geven adviezen aan cliënten, opdrachtgevers en organisaties bij het nemen van besluiten in voorkomende processen. Loopbaanadviseurs doen dit door het aandragen van informatie, voorstellen en oplossingsrichtingen. De loopbaanadviseur evalueert en anticipeert op de gevolgen van besluiten."

5) Coachen3: "De loopbaanadviseur ontwikkelt cliënten, groepen en organisaties naar zelfstandig en ondernemend gedrag op het terrein van loopbaan(beleid). De loopbaanadviseur helpt cliënten en organisaties zichzelf te ontwikkelen. De loopbaanadviseur motiveert en deelt kennis. De loopbaanadviseur beïnvloedt anderen om tot afgewogen besluiten te komen. De loopbaanadviseur bewaakt haalbaarheid en realiteitszin."

Deze vijf competenties zijn onderwerp van vijf casusvoorbeelden die van de te certificeren loopbaanadviseurs gevraagd worden om te beschrijven in het kader van hun initiële certificering.

\footnotetext{
${ }^{3}$ Coachen komt oorspronkelijk van het Engelse woord coach; een voertuig dat mensen van A naar B brengt. In de loopbaanadvisering heeft het woord coachen dezelfde betekenis, namelijk: mensen van $A$ naar B begeleiden.
} 
Aan het onderhavige onderzoek naar het kwaliteitsgehalte van de beschrijving van de specifieke competenties in het kader van de begeleiding, hebben 100 te certificeren loopbaanadviseurs meegedaan met in totaal 500 casusvoorbeelden. Figuur 5.1 bevat een voorbeeld van een casusvoorbeeld van bijzondere kwaliteit, dat geschreven werd door Mevrouw Nicole Noyens, RL, ${ }^{4}$ inzake 'inlevingsvermogen'.

"Mijn cliënte is een vrouw van begin 50. Ze verliest haar baan door een reorganisatie. Ze heeft geknokt voor behoud van haar functie, maar zonder resultaat. Al met al een heftige periode; ze is ook een jaar daarvoor gescheiden. Ze oogt vrolijk, heel sterk, een optimistische doorzetter. Aandacht voor ontslagverwerking hoeven we niet te besteden. Heeft ze niet nodig. Ze wil aan de slag met solliciteren en netwerken. Mijn gevoel zegt mij eigenlijk al meteen dat zij zich te sterk houdt; dat ze niet genoeg ruimte geeft voor haar gevoel. Als ik dat aan haar voorleg, ontkent ze dat. Zij heeft een fietstocht gemaakt van twee maanden, haar droom, en alles gaat prima. Wel heeft ze last van een 'frozen shoulder' door overbelasting. Iedere keer als ik haar zie, kan ze minder door de pijn. Ik zie ook de pijn in haar ogen, andere pijn. Als ik dat benoem valt er een last van haar schouder. Ze is heel blij met de (h)erkenning en kan loslaten dat ze in haar outplacementtraject ook de sterkste moet zijn."

Figuur 5.1. Casusvoorbeeld inlevingsvermogen.

\subsubsection{Kernoragen}

Om de mate waarin loopbaanadviseurs beschikken over de vijf specifieke competenties goed te kunnen beoordelen en te onderzoeken of de competenties samenhangen met elkaar en met andere variabelen, zoals de achtergrondvariabelen van de adviseurs, zijn vier kernvragen geformuleerd.

\footnotetext{
${ }^{4} R L$ is de titel die door CMI verstrekt wordt aan gecertificeerde loopbaanadviseurs. RL staat voor "Register Loopbaanprofessional".
} 
Ten eerste is het belangrijk om inzicht te verkrijgen in de mate waarin loopbaanadviseurs beschikken over de vijf verschillende specifieke competenties. Dit zou immers de kwaliteit van de begeleiding ten goede kunnen komen. De eerste kernvraag luidt derhalve als volgt:

Kernvraag 1: In welke mate heeft de loopbaanadviseur de vijf verschillende specifieke competenties ontwikkeld?

Ten tweede is het belangrijk om te onderzoeken of er tussen de vijf specifieke competenties een relatie bestaat. Bijvoorbeeld of inlevingsvermogen samenhangt met adviseren of coachen. Verwacht mag bijvoorbeeld worden dat hoe beter het inlevingsvermogen van een adviseur ontwikkeld is, hoe beter deze de cliënt kan coachen. De tweede kernvraag luidt daarom als volgt:

Kernvraag 2: Bestaat er samenhang tussen de vijf specifieke competenties van de loopbaanadviseur en hoe sterk is deze samenhang?

Ten derde onderscheidt CMI bij de certificering van loopbaanadviseurs drie niveaus van vakbekwaamheid, naargelang de loopbaanadviseur meer 'in de breedte' van het vakgebied werkt. Verwacht zou kunnen worden dat adviseurs die op een breder niveau opereren aandacht voor andere competenties hebben dan adviseurs die op een smaller niveau werken. Dit zou bijvoorbeeld zo kunnen zijn voor 'inlevingsvermogen', omdat deze competentie meer diepgang zou kunnen vereisen en derhalve ook meer ervaring. In het onderhavige hoofdstuk zal onderzocht worden of de competenties verschillen tussen de drie CMI-niveaus. Dit leidt tot de derde kernvraag. Deze luidt: 
Kernvraag 3: Bestaan er verschillen tussen de drie CMI-niveaus in de mate waarin de loopbaanadviseur de vijf specifieke competenties heeft ontwikkeld?

Ten vierde is het interessant om te onderzoeken of er een relatie bestaat tussen bepaalde achtergrondvariabelen van de loopbaanadviseur en de mate waarin de loopbaanadviseur de verschillende specifieke competenties heeft ontwikkeld. Een voorbeeld hiervan is de vraag of specifieke werkervaring de mate van ontwikkeling van de competentie adviseren beïnvloedt. Dit leidt tot de vierde kernvraag:

Kernvraag 4: Is er een relatie tussen de achtergrondvariabelen (gender, leeftijd, opleiding en specifieke werkervaring) van de loopbaanadviseur en de mate waarin deze de vijf specifieke competenties heeft ontwikkeld?

\subsubsection{Opbouw van het hoofdstuk}

De indeling van dit hoofdstuk is als volgt: in paragraaf 5.2 zal de methodiek uitgewerkt worden door in te gaan op het design, de steekproef en de meetinstrumenten. In paragraaf 5.3 zullen de onderzoeksresultaten per kernvraag uitgewerkt worden, terwijl in de discussieparagraaf 5.4 de conclusies per kernvraag besproken zullen worden, die zullen leiden tot discussie en aanbevelingen.

\subsection{Methodiek}

\subsubsection{Design}

Het onderhavige hoofdstuk betreft dossieronderzoek. De dossiers zijn afkomstig van CMI. Elk dossier bevat onder meer een hoofdstuk inzake de specifieke competenties met vijf casusvoorbeelden, opgesteld door loopbaanadviseurs ten behoeve van de certificering door CMI; dit om te toetsen in welke mate 
de loopbaanadviseurs de vijf specifieke competenties hebben ontwikkeld. Deze competenties worden door de CMI-toetsingscommissie, bestaande uit een hoogleraar en een loopbaanexpert, getoetst. De kandidaten worden geconfronteerd met het beroepsprofiel, waarbij onderzocht wordt of de kandidaten minimaal de taken op het eigen niveau ook daadwerkelijk verrichten, gebruikmakende van de desbetreffende specifieke competenties, zoals in het beroepsprofiel en de verbijzondering van het beroepsprofiel wordt aangegeven. Indien hieraan voldaan wordt, voldoet de kandidaat aan dit gedeelte van de toets.

Uit het CMI-dossierbestand werden uit honderd CMI-dossiers vijf casusvoorbeelden met betrekking tot de vijf specifieke competenties uit de periode 2012 - 2014 opgenomen ter beoordeling 5 . De 500 casusvoorbeelden van specifieke competenties uit de in totaal honderd dossiers werden vervolgens verdeeld over twintig experts. Daarbij werd elk casusvoorbeeld door twee experts beoordeeld. Per expert komt dat neer op tien dossiers met elk vijf casusvoorbeelden van vijf specifieke competenties, ofwel 50 casusvoorbeelden in totaal. Vervolgens werd aan de experts het verzoek gedaan om deze casusvoorbeelden te beoordelen.

\subsubsection{Steekproef}

Van de in totaal 500 casusvoorbeelden hadden er 145 betrekking op de certificering voor CMI-niveau A (29\%), 295 (59\%) op niveau B en 60 (12\%) op niveau C. Zoals Tabel 5.1 toont was de gemiddelde leeftijd van deze loopbaanadviseurs 49 jaar $(S D=6,71)$. In het onderzoek waren vrouwen in de meerderheid, te weten $76 \%$

\footnotetext{
${ }^{5}$ Er werden honderd dossiers en dus 500 casusvoorbeelden uit de periode 2012 - 2014 opgenomen, beginnend met het laatst beschikbare dossier en vervolgens terugtellend, zodat er uiteindelijk honderd dossiers en dus 500 casusvoorbeelden beschikbaar waren. De tussenliggende ontbrekende dossiers behoren toe aan adviseurs die om welke reden dan ook hun certificaat inmiddels hebben laten verlopen en verzocht hebben hun dossiers te vernietigen.
} 
van de loopbaanadviseurs. De loopbaanadviseurs hadden allen een hbo- $(66 \%)$ of een wo-opleiding (34\%), maar niet noodzakelijkerwijs een hbo- of wo-opleiding in loopbaanadvisering. De gemiddelde specifieke werkervaring was 10 jaar $(S D=4,85)$. Om te worden toegelaten tot de certificering op het meest smalle niveau A, moet de te certificeren loopbaanadviseur minimaal drie jaar specifieke ervaring kunnen aantonen. Voor het B-niveau is dit vijf jaar en voor het C-niveau zes jaar.

De 20 experts die de ontwikkeling van de specifieke competenties beoordeelden waren voor het merendeel mentoren en bestuursleden van CMI, aangevuld met experts uit aanpalende beroepsgroepen, zoals een Executive Search ${ }^{6}$ expert, een psycholoog en een arbeidsdeskundige. Steeds werden twee experts, met de auteur van dit proefschrift als linking pin, gevraagd om ieder voor zich dezelfde casusvoorbeelden te beoordelen. Derhalve werden alle casusvoorbeelden door drie experts beoordeeld.

Tabel 5.1

Achtergrondvariabelen van de loopbaanadviseurs $(N=100)$.

\begin{tabular}{cccc}
\hline Gender & Leeftijd & Opleiding & $\begin{array}{c}\text { Specifieke } \\
\text { werkervaring }\end{array}$ \\
\hline Man: 24 & $M=49$ jaar & wo: 34 & $M=10$ jaar \\
Vrouw: 76 & $(S D=6,71)$ & hbo: 66 & $(S D=4,85)$ \\
\hline
\end{tabular}

\subsubsection{Meetinstrumenten}

Voor het beantwoorden van de vier kernvragen van dit onderzoek werd uitgegaan van de vijf specifieke competenties voor loopbaanadviseurs, zoals geformuleerd door CMI, te weten: 1) inlevingsvermogen; 2) effectief communiceren; 3)

\footnotetext{
${ }^{6}$ Executive Search bedrijven bieden in concurrentie met loopbaanadviesbureaus al enige jaren loopbaanadvisering aan.
} 
reflecteren; 4) adviseren; en 5) coachen. Door CMI werd aan de loopbaankandidaten voor certificering de opdracht gegeven een dossier samen te stellen ten behoeve van hun certificering. In het dossier dienden de kandidaten onder meer vijf casusvoorbeelden van specifieke competenties te geven, om de toepassing van elk van de vijf specifieke competenties bij de begeleiding van hun cliënten te beschrijven. Aan de kandidaten werd de volgende opdracht gegeven: "Geef een voorbeeld van de toepassing van elk van de vijf specifieke competenties, niet ouder dan twee jaar, in overeenstemming met de definities ${ }^{7}$ van de specifieke competenties". Deze opdracht kan goed uitgevoerd worden, gezien het feit dat de te certificeren kandidaten voldoende ervaring hebben als ze minimaal drie jaar in het vakgebied werkzaam zijn geweest.

De vraag aan de beoordelende experts luidde als volgt: "Beoordeel de 50 casusvoorbeelden op een schaal van $1-5$, waarbij 5 het beste bij de bijgaande definitie van één van de vijf specifieke competenties past en 1 het minste past bij die definitie. Daarbij is het de bedoeling om te beoordelen in welke mate de toepassing van ieder van de vijf specifieke competenties, voor de vijf casusvoorbeelden, overeenkomt met de CMI-definities van de vijf specifieke competenties."

\subsection{Resultaten}

Kernvraag 1 luidde: In welke mate heeft de loopbaanadviseur de vijf verschillende specifieke competenties ontwikkeld? Deze vraag werd voor elke competentie beantwoord op basis van de gemiddelden van de beoordelingen door drie experts voor iedere specifieke competentie. Zoals uit Tabel 5.2 blijkt is de gemiddelde beoordeling van alle specifieke competenties tezamen $M=3,72$ met een SD van 0,74 . Advisering scoort gemiddeld met $M=3,93$ het hoogst, gevolgd door

\footnotetext{
${ }^{7}$ Zie voor de exacte definities van de vijf specifieke competenties die CMI hanteert de inleiding van dit hoofdstuk.
} 
reflecteren met $\mathrm{M}=3,74$ en coachen met $\mathrm{M}=3,71$. Ten slotte scoren inlevingsvermogen met 3,67 en effectief communiceren met 3,60 het laagst. Alle gemiddelde beoordelingen van de vijf specifieke competenties zijn ruim boven 3,50 en derhalve voldoende. De standaarddeviaties geven aan in hoeverre de beoordelaars het met elkaar eens waren. Bij een lage standaarddeviatie is de spreiding van de antwoorden laag. De spreiding van de beoordelingen van de casusvoorbeelden inzake effectief communiceren is het kleinst $(S D=0,63)$. De beoordelaars waren het derhalve grotendeels met elkaar eens dat de adviseurs voor effectief communiceren minder goede casusvoorbeelden uitwerkten. Over de beoordeling van het inlevingsvermogen en reflecteren zijn de beoordelaars het onderling het minst eens gezien de hogere relatieve spreiding $(S D=0,80$ respectievelijk $S D=0,86)$. Samengevat kan kernvraag 1 als volgt beantwoord worden: de beoordeelde loopbaanadviseurs hebben alle vijf verschillende specifieke competenties voldoende ontwikkeld.

Kernvraag 2 luidde: Bestaat er een onderlinge relatie tussen de vijf specifieke competenties van de loopbaanadviseur en hoe groot is de relatie? De onderlinge relaties tussen de vijf specifieke competenties werden onderzocht met een Pearson correlatieanalyse (zie Tabel 5.2). De sterkste relatie is die tussen 'effectief communiceren' en 'adviseren', namelijk $r=0,32(p<0,01)$. Dit betekent dat hoe beter een adviseur de competentie effectief communiceren heeft ontwikkeld, hoe beter hij of zij de cliënt kan adviseren. Ook tussen adviseren en coachen is er samenhang, namelijk $r=0,27(p<0,01)$. Tevens is er samenhang tussen reflecteren en effectief communiceren, namelijk: $r=0,24(p<0,01)$. Bovendien bleek er een marginaal significante samenhang te zijn tussen adviseren en reflecteren, namelijk $r=0,19(p<$ $0,10)$. Opvallend is dat 'inlevingsvermogen', afgezien van de marginaal significante samenhang met effectief communiceren, $r=0,20(p<0,10)$, geen samenhang vertoont met de andere specifieke competenties. 
Tabel 5.2

Gemiddelden en standaarddeviaties van en onderlinge relaties tussen de vijf specifieke competenties van loopbaanadviseurs.

$\begin{array}{llllllll}\text { Specifieke competentie } & M & S D & 1 & 2 & 3 & 4 & 5\end{array}$

1. Inlevingsvermogen $\quad 3,65 \quad 0,90 \quad-$

2. Effectief communiceren $3,60 \quad 0,67 \quad 0,20^{+} \quad-$

3. Reflecteren $\quad 3,73 \quad 0,88 \quad 0,01 \quad 0,24^{*} \quad-$

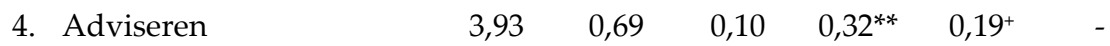

$\begin{array}{lllllll}\text { 5. Coachen } & 3,71 & 0,71 & 0,10 & 0,15 & 0,07 & 0,27^{* *}\end{array}$

Noot: ${ }^{*} p<0,05 ;{ }^{* *} p<0,01 ;+p<0,10$.

Samengevat kan gesteld worden dat alle specifieke competenties aan minimaal één andere competentie gerelateerd zijn. Hierbij bestaat de sterkste relatie tussen adviseren en effectief communiceren, gevolgd door de samenhang tussen adviseren en coachen. Ten slotte blijkt effectief communiceren gerelateerd te zijn aan zowel reflecteren als in iets mindere mate aan inlevingsvermogen.

Kernvraag 3 luidde: Bestaan er verschillen tussen de drie CMI-niveaus in de mate waarin de loopbaanadviseur de vijf specifieke competenties heeft ontwikkeld? Voor het beantwoorden van deze vraag werd vijfmaal een Anova uitgevoerd. Uit Tabel 5.3 valt af te lezen dat er voor twee van de vijf specifieke competenties significante verschillen bestaan tussen de drie CMI-niveaus. De significante verschillen betreffen inlevingsvermogen en coachen. Voor inlevingsvermogen zijn 
de gemiddelden: voor CMI-niveau A: $M=3,86$; voor niveau B: $M=3,62$ en voor C: $M=3,25$. Voor coachen zijn de gemiddelden: voor niveau A: $M=3,83$; voor niveau B: $M=3,73$ en voor niveau C: $M=3,31$. Dat wil zeggen dat adviseurs op een 'smaller' niveau beter zijn in zowel inleven als coachen dan adviseurs op een 'breder' niveau.

Daarnaast werden voor de overige drie competenties - effectief communiceren, reflecteren en adviseren - enkele kleine, maar niet significante, verschillen tussen de drie CMI-niveaus zichtbaar. Voor deze competenties bleek juist dat adviseurs op een breder niveau de competentie in het algemeen iets beter hadden ontwikkeld dan de adviseurs op de smallere CMI-niveaus (zie Tabel 5.3).

Samengevat bestaan er inderdaad significante verschillen tussen de drie CMIniveaus, maar dat geldt alleen voor twee van de vijf specifieke competenties, namelijk voor: inlevingsvermogen en coachen. Voor beide specifieke competenties geldt dat de adviseurs die werken op een smaller niveau de competenties inlevingsvermogen en coachen beter ontwikkeld te hebben dan adviseurs die werken op een breder niveau.

Kernvraag 4 luidde: Is er een relatie tussen de achtergrondvariabelen (gender, leeftijd, opleiding en specifieke werkervaring) van de loopbaanadviseur en de mate waarin deze de vijf specifieke competenties heeft ontwikkeld? Om deze vraag te kunnen beantwoorden werden Spearman's en Pearson's correlatietests toegepast. De Spearman's correlatie test werd ingezet voor gender en opleiding, aangezien dit geen continue, maar ordinale variabelen zijn. Voor de doorlopende variabelen (leeftijd en specifieke werkervaring) werd een Pearson's correlatietest gedaan. De achtergrondvariabelen werden afgezet tegen de mate van ontwikkeling van iedere competentie. Tabel 5.4 toont de samenhang tussen elk van de vijf specifieke competenties en de achtergrondvariabelen. 


\section{Tabel 5.3}

Verschillen tussen de drie CMI-niveaus in de mate van ontwikkeling van de vijf specifieke competenties van loopbaanadviseurs.

\begin{tabular}{|c|c|c|c|c|c|}
\hline Competentie & $\begin{array}{l}\text { CMI- } \\
\text { niveau }\end{array}$ & $M$ & $S D$ & $\begin{array}{l}\text { Sum of } \\
\text { squares }\end{array}$ & $F$ \\
\hline \multirow[t]{4}{*}{ 1. Inlevingsvermogen } & & & & 3,18 & $2,05^{*}$ \\
\hline & A & 3,86 & 0,90 & & \\
\hline & B & 3,62 & 0,90 & & \\
\hline & $\mathrm{C}$ & 3,25 & 0,84 & & \\
\hline \multirow{4}{*}{ 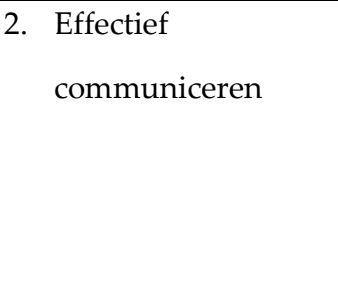 } & & & & 0,00 & 0,60 \\
\hline & A & 3,52 & 0,61 & & \\
\hline & B & 3,66 & 0,66 & & \\
\hline & C & 3,50 & 0,86 & & \\
\hline \multirow[t]{4}{*}{ 3. Reflecteren } & & & & 0,21 & 0,31 \\
\hline & A & 3,62 & 0,92 & & \\
\hline & B & 3,77 & 0,86 & & \\
\hline & C & 3,78 & 0,92 & & \\
\hline \multirow[t]{4}{*}{ 4. Adviseren } & & & & 0,10 & 0,22 \\
\hline & A & 3,86 & 0,74 & & \\
\hline & B & 3,96 & 0,71 & & \\
\hline & $\mathrm{C}$ & 3,97 & 0,48 & & \\
\hline \multirow[t]{4}{*}{ 5. Coachen } & & & & 2,31 & $2,38^{*}$ \\
\hline & A & 3,83 & 0,61 & & \\
\hline & B & 3,73 & 0,76 & & \\
\hline & $\mathrm{C}$ & 3,31 & 0,69 & & \\
\hline
\end{tabular}

${ }^{*} p<0,05$. 
Gender: gender werd gecodeerd als: $0=$ man en $1=$ vrouw. Er bleek een marginaal significante correlatie te bestaan tussen gender en inlevingsvermogen, namelijk: $r=0,17(p<0,10)$. Dit geeft aan dat bij vrouwelijke loopbaanadviseurs het inlevingsvermogen over het algemeen iets beter ontwikkeld is dan bij hun mannelijke collegae. Voor gender blijkt er eveneens een marginale correlatie met 'effectief communiceren' te bestaan, namelijk: $r=0,17(p<0,10)$. Vrouwelijke loopbaanadviseurs blijken dus iets effectiever te communiceren dan mannelijke adviseurs. Voor de competenties reflecteren, adviseren en coachen werd geen samenhang gevonden met gender. Er bestaat dus geen verschil tussen mannen en vrouwen in de mate waarin zij deze drie specifieke competenties ontwikkeld hebben.

Leeftijd: Er werd een negatieve correlatie tussen 'leeftijd' en 'effectief communiceren' gevonden: $r=-0,20(p<0,05)$. Dat wil dus zeggen dat hoe jonger de loopbaanadviseur is, hoe effectiever het vermogen tot communiceren is. Er werd geen correlatie gevonden tussen leeftijd en de vier andere specifieke competenties. Leeftijd heeft dus geen invloed op het inlevingsvermogen, reflecteren, adviseren en coachen.

Opleiding: er werd een marginaal significante negatieve relatie gevonden tussen het opleidingsniveau van de loopbaanadviseurs en de competentie coaching, namelijk: $r=-0,17(p<0,10)$. Dit betekent dat de hbo-opgeleide loopbaanadviseurs de competentie coachen een fractie beter hebben ontwikkeld dan de wo-opgeleide loopbaanadviseurs. Er werd geen correlatie gevonden tussen het opleidingsniveau en de vier andere specifieke competenties. Opleiding heeft dus geen invloed op de competenties inlevingsvermogen, effectief communiceren, reflecteren, en adviseren.

Specifieke werkervaring: In tegenstelling tot wat men zou verwachten werd er geen correlatie gevonden tussen de specifieke werkervaring van de loopbaan- 
adviseurs en de mate waarin zij de vijf specifieke competenties ontwikkeld hebben, afgezien van een marginaal significante negatieve relatie tussen iemands specifieke werkervaring en inlevingsvermogen, namelijk: $r=-0,15(p<0,10)$. Dat wil zeggen dat adviseurs met minder specifieke werkervaring over het algemeen een fractie meer inlevingsvermogen tonen dan adviseurs met meer specifieke werkervaring.

Tabel 5.4

Correlatietabel achtergrondvariabelen en specifieke competenties.

\begin{tabular}{|c|c|c|c|c|c|}
\hline & $\begin{array}{l}\text { Inlevings- } \\
\text { vermogen }\end{array}$ & $\begin{array}{c}\text { Effectief } \\
\text { com. }\end{array}$ & Reflecteren & Adviseren & Coachen \\
\hline Gender (rho) & $0,17^{+}$ & $0,17^{+}$ & $-0,04$ & 0,09 & 0,08 \\
\hline Leeftijd $(r)$ & 0,04 & $-0,20^{*}$ & $-0,06$ & $-0,02$ & $-0,01$ \\
\hline Opleiding (rho) & $-0,03$ & 0,03 & $-0,12$ & $-0,05$ & $-0,17^{+}$ \\
\hline $\begin{array}{l}\text { Specifieke } \\
\text { werkervaring }(r)\end{array}$ & $-0,15^{+}$ & $-0,04$ & $-0,01$ & $-0,06$ & $-0,08$ \\
\hline
\end{tabular}

Noot. ${ }^{*} p<0,05 ;{ }^{* *} p<0,01 ;+p<0,10$.

Samengevat betekent dit dat het inlevingsvermogen en het effectief communiceren over het algemeen iets beter ontwikkeld zijn bij vrouwelijke loopbaanadviseurs dan bij hun mannelijke collegae, al zijn beide relaties slechts marginaal significant. Leeftijd blijkt een negatieve relatie te hebben met het effectief kunnen communiceren. Voorts is er een marginaal significante negatieve relatie tussen het opleidingsniveau van de loopbaanadviseur en de competentie coachen. 
Ten slotte werd er een marginaal significante negatieve relatie gevonden tussen iemands specifieke werkervaring en inlevingsvermogen.

\subsection{Discussie}

\subsubsection{Bevindingen van het onderzoek}

De bevindingen van het onderzoek zijn neergelegd in de vier kernvragen, waarvan de conclusies hieronder worden behandeld.

Kernvraag 1 luidde: In welke mate heeft de loopbaanadviseur de vijf verschillende specifieke competenties ontwikkeld? Het onderzoek laat zien dat de loopbaanadviseurs de vijf specifieke competenties over het algemeen voldoende ontwikkeld hebben. Voldoende is in dit verband gedefinieerd als meer dan 3 op de schaal van $1-5$, waarbij 1 de minste en 5 de meeste ontwikkeling aangeeft. Daarbij is de mate van ontwikkeling van de competentie advisering het hoogst. Het laagst scoort de competentie effectief communiceren, al wordt deze competentie gemiddeld nog steeds als voldoende beoordeeld. Alle specifieke competenties tezamen worden gemiddeld met voldoende beoordeeld.

Kernvraag 2 luidde: Bestaat er een relatie tussen de vijf specifieke competenties van de loopbaanadviseur en hoe groot is de relatie? Zoals de resultaten laten zien, worden er diverse relaties gevonden tussen verschillende specifieke competenties, waardoor kernvraag 2 gedeeltelijk positief beantwoord kan worden. Dat er samenhang is tussen adviseren en coachen is niet onverwacht. Beide competenties liggen als discipline veelal in elkaars verlengde. Loopbaanadviseurs zijn gewend om adviezen te geven en doen dat ook als er gecoacht moet worden. Loopbaanadviseurs zullen echter naar manieren moeten zoeken om meer effectief te coachen. Dus zoals CMI het definieert (www.cminl.nl) om: "cliënten, groepen en organisaties te ontwikkelen naar zelfstandig en ondernemend gedrag op het terrein 
van loopbaanontwikkeling", óf zoals Meyer et al. (2011; p. 15) het uitdrukken: "Coaching is het begeleiden van een cliënt in het proces van zichzelf ontwikkelen teneinde zijn functioneren te verbeteren." Bij coachen helpt de loopbaanadviseur cliënten en organisaties dus primair zichzelf gericht te ontwikkelen. De samenhang tussen adviseren en effectief communiceren verbaast niet. Goed adviseren kan immers nauwelijks zonder effectief te communiceren. Ook is er een (wat minder grote) samenhang tussen effectief communiceren en reflecteren en tussen adviseren en reflecteren.

Gezien de significante samenhang tussen coachen en adviseren ligt het ook in de lijn van verwachting dat er ook een samenhang is tussen coachen en reflecteren en tussen adviseren en reflecteren. Dat blijkt echter niet het geval te zijn voor coachen en reflecteren. Wel kan geconstateerd worden dat effectief communiceren en inlevingsvermogen (marginaal) samenhangen. Ten slotte dient vermeld te worden dat er een relatie verwacht zou kunnen worden tussen inleven en adviseren, alsook een relatie tussen inleven en coachen. Het lijkt immers moeilijk om goed te adviseren of te coachen zonder dat men zich als adviseur echt inleeft in de situatie van de cliënt. Het onderzoek bevestigt die verwachting niet. Het zou kunnen dat de te certificeren loopbaanadviseurs het moeilijk vinden om hun inlevingsvermogen te vatten in een goed casusvoorbeeld.

Kernvraag 3 luidde: Bestaan er verschillen tussen de drie CMI-niveaus in de mate waarin de loopbaanadviseur de vijf specifieke competenties heeft ontwikkeld? Gebleken is dat er voor drie van de vijf specifieke competenties, namelijk reflecteren, effectief communiceren en adviseren, tussen de drie CMI-niveaus geen significante verschillen in ontwikkeling bestaan. Dat wil zeggen dat de gemiddelde waarden van de beoordelingen voor alle drie niveaus op eenzelfde niveau liggen. 
Voor inlevingsvermogen en coachen werd er echter wel een significant verschil tussen de drie niveaus gevonden. Beide specifieke competenties zijn door adviseurs op het smallere niveau beter ontwikkeld dan door adviseurs op het bredere niveau. Dit resultaat is zeer opmerkelijk. Hoewel het bredere niveau in principe alleen een aanduiding geeft voor de breedte van het werkgebied van de loopbaanadviseur, komt het er tevens veelal op neer dat de loopbaanadviseur op dat niveau meer ervaring heeft dan de loopbaanadviseur op het smallere niveau. Om die reden had verwacht mogen worden dat loopbaanadviseurs op het bredere niveau deze competentie meer ontwikkeld zouden hebben.

Dat de loopbaanadviseurs op het smallere niveau hoger scoren op de competentie coaching is misschien minder vreemd. Mogelijk voeren de loopbaanadviseurs op het bredere niveau zelf meer beleidsmatige taken uit en laten zij het werk met de cliënten voornamelijk over aan loopbaanadviseurs op de smallere Aen B-niveaus.

Voor de ontwikkeling van de competentie adviseren, zoals ook voor de competentie coachen, zou er ook een significant verschil tussen de niveaus verwacht mogen worden. Dit blijkt echter niet het geval te zijn. Wel blijken de adviseurs over advisering op alle niveaus goede casusvoorbeelden te kunnen schrijven. De gemiddelde waarden liggen dan ook dicht bij elkaar. Er moeten derhalve factoren in het spel zijn waardoor de gemiddelde waarden van beide competenties niet significant verschillen. Een mogelijke oorzaak hiervoor zou kunnen zijn dat de adviseurs op het bredere niveau door hun meer beleidsmatige insteek onvoldoende cliënten zien.

Kernvraag 4 luidde: Is er een relatie tussen achtergrondvariabelen van de loopbaanadviseur (gender, leeftijd, opleiding, werkervaring) en de mate waarin deze de vijf specifieke competenties heeft ontwikkeld? Gebleken is dat de vijf specifieke competenties slechts met een beperkt aantal achtergrondvariabelen 
samenhangen: Er is een (marginale) relatie tussen gender en inlevingsvermogen. Het inlevingsvermogen van vrouwelijke loopbaanadviseurs is gemiddeld iets beter dan dat van mannelijke adviseurs. Er is ook een marginale relatie tussen gender en effectief communiceren. Vrouwelijke loopbaanadviseurs kunnen blijkbaar over het algemeen ook iets beter communiceren dan mannelijke adviseurs. Ook blijkt er een significante negatieve samenhang te zijn tussen leeftijd en effectief communiceren. Dit betekent dat hoe jonger de loopbaanadviseurs zijn, hoe effectiever zij communiceren. Voor leeftijd bestaan er geen significante relaties met de specifieke competenties inlevingsvermogen, reflecteren, adviseren en coachen.

Daarnaast is er een marginale negatieve samenhang tussen opleidingsniveau en coachen. Hbo-opgeleide loopbaanadviseurs blijken op het gebied van coachen iets betere loopbaanadviseurs te zijn dan wo-opgeleide loopbaanadviseurs. De hboopgeleide loopbaanadviseur beheerst het één-op-één werk blijkbaar beter dan de wo-opgeleide loopbaanadviseurs, die veelal meer beleidsmatig werken. De specifieke werkervaring van de adviseurs blijkt geen relatie te hebben met één van de specifieke competenties, afgezien van een marginaal negatieve relatie met inlevingsvermogen. De adviseur met minder specifieke werkervaring heeft blijkbaar iets meer inlevingsvermogen dan de adviseur met meer specifieke werkervaring. Dit is opmerkelijk. Deze specifieke competenties zijn juist door CMI gekozen, omdat deze goed passend zijn voor de begeleiding in dit vakgebied. Het onderzoek wijst echter anders uit.

\subsubsection{Beperkingen}

Een resultaat gemiddeld groter dan 3,50 op een vijfpuntsschaal voor de ontwikkeling van de specifieke competenties is een voldoende beoordeling, met name ook omdat geen van de 20 beoordelingen van de loopbaanexperts over 50 casusvoorbeelden gemiddeld lager dan 3 beoordeeld werden. Deze uitkomst blijft 
echter relatief; als de lat voor 'voldoende' hoger zou worden gelegd, bijvoorbeeld bij een judicium hoger dan 4, dan waren slechts 10 van de 50 gemiddelde beoordelingen voldoende, namelijk twee voor inlevingsvermogen, twee voor reflecteren, vier voor adviseren en twee voor coachen. Voor effectief communiceren is geen van de gemiddelde beoordelingen hoger dan 4, maar er zijn ook geen gemiddelde beoordelingen kleiner dan 3 .

Betrouwbaarheid: De rol van de auteur van dit proefschrift houdt op zich reeds een beperking in. Om consistent te blijven met de rest van het proefschrift heeft de auteur gekozen om alle 500 te beoordelen casusvoorbeelden van de specifieke competenties door drie experts te laten beoordelen. De bij de beoordeling ingeschakelde experts hebben voldoende expertise om vijftig casusvoorbeelden op dezelfde manier en op hetzelfde niveau te beoordelen, maar dat hoeft natuurlijk niet zo te zijn. Bovendien heeft de auteur van dit proefschrift zelf als 'linking pin' ook alle casusvoorbeelden beoordeeld, hetgeen een extra subjectief element toevoegt aan het onderzoek. Gezien dit subjectieve element werd onderzocht welke invloed het heeft als voor alle beoordelingen de auteur van dit proefschrift niet mee doet. Het bleek dat er geen verschil wordt waargenomen in de gemiddelde beoordelingen als de auteur van dit proefschrift niet zou meedoen.

Validiteit: De interne validiteit is bij praktijkgericht dossieronderzoek veelal laag. Alle 500 casusvoorbeelden werden door de loopbaanadviseurs op hun eigen wijze, op hun eigen moment en op hun eigen manier geschreven, waardoor er ruis ontstaat bij het meten van de specifieke competenties van de loopbaanadviseur.

De externe validiteit is bij dossieronderzoek doorgaans hoog. De casusvoorbeelden werden opgeschreven door loopbaanadviseurs die het voorbeeld zelf meegemaakt en beleefd hebben. De context voor het onderzoek is derhalve authentiek. 
De vraag is echter of de steekproef ook voldoende representatief is voor de gehele beroepsgroep. Gezien het feit dat het gaat om loopbaanadviseurs die hun vakbekwaamheid aangetoond hebben en daarmee de titel Register Loopbaanprofessional hebben verkregen, zullen zij zeker representatief zijn voor de groep van 800 gecertificeerde loopbaanadviseurs, maar niet persé voor alle 15.000 loopbaanadviseurs die naar schatting in Nederland deel uitmaken van de beroepsgroep. De meesten van deze 15.000 loopbaanadviseurs hebben immers hun vakbekwaamheid niet aangetoond. Derhalve kan de conclusie voor de externe validiteit zijn dat, als men wat betreft generalisatie uitgaat van Register Loopbaanprofessionals die hun vakbekwaamheid hebben aangetoond, de externe validiteit hoog zal zijn, maar dat de generaliseerbaarheid van de resultaten naar de gehele beroepsgroep mogelijk laag is.

\subsubsection{Aanbevelingen}

Aanpassing specifieke competenties

Gezien de beperkte onderlinge samenhang in ontwikkeling tussen de vijf specifieke competenties, alsmede de geringe samenhang tussen de specifieke competenties en de CMI-niveaus en achtergrondvariabelen, kan men zich afvragen of de door CMI gebruikte competenties wel voldoende kenmerkend zijn om als belangrijkste competenties voor de begeleiding van de cliënten door de loopbaanadviseurs ingezet te worden. Deze vraag komt temeer op, omdat Ofman ${ }^{8}$ (1992), in het kader van de onderzochte 500 casusvoorbeelden, zeer frequent door kandidaten voor certificering genoemd wordt als kennisbron voor competenties. Mogelijk zijn er andere competenties die enkele van de huidige specifieke competenties dienen te

\footnotetext{
${ }^{8}$ Ofman heeft bovendien een spel ontworpen waardoor er op speelse wijze aan adviseur en aan cliënt duidelijk gemaakt wordt met hoeveel competenties er gewerkt kan worden.
} 
vervangen. Voorbeelden hiervan zijn: baanbrekend, confronterend, openheid, relativerend vermogen, zelfinzicht en zelfbewustheid.

Ofman bracht 164 competenties in kaart. Als door nader onderzoek zou blijken welke competenties enkele van de huidige specifieke competenties van CMI zouden kunnen vervangen, zou het onderlinge verband sterker kunnen worden. Dat zou voor de kwaliteit van de CMI-toetsing, maar ook voor de beroepsgroep als geheel, belangrijke informatie kunnen opleveren. In dit kader hebben allerlei auteurs (zoals Briggs, 2000; Byron, 2002; Hollander \& Wijnberg, 2006; Palmer \& Whybrow, 2007; Schein, 2002; Seegers, 2008) zich toegelegd op literatuur waar loopbaanadviseurs lering uit kunnen trekken om het effect van de begeleiding te versterken. Onderzoek competentie inlevingsvermogen

De competentie inlevingsvermogen wordt blijkbaar door vele te certificeren loopbaanadviseurs als een moeilijk te omschrijven begrip gezien. Daardoor lijkt deze competentie minder goed ontwikkeld. Inlevingsvermogen is afhankelijk van goed kunnen luisteren, terwijl loopbaanadvisering als vak zonder goed kunnen luisteren onuitvoerbaar is. Dit maakt het erg belangrijk om te onderzoeken of inlevingsvermogen daadwerkelijk minder ontwikkeld is dan de meeste andere specifieke competenties en waardoor dit komt. 



\section{HOOFDSTUK 6}

\section{ARBEIDSMARKTBEGELEIDING}

\subsection{Inleiding}

De arbeidsmarkt is immer in beweging, waardoor er steeds spanning ontstaat tussen de vraag en het aanbod van arbeid. Dit spanningsveld is het werkterrein van de loopbaanadviseur, die adviezen geeft aan cliënten hoe zij met hun talenten in de arbeidsmarkt een passende baan ${ }^{1}$ kunnen vinden. De arbeidsmarkt is groot en beweeglijk en daardoor ook voor een loopbaanadviseur moeilijk om deze in z'n totaliteit te kunnen overzien. Dat is ook niet nodig, maar het is wel noodzakelijk om de arbeidsmarkt globaal zo goed mogelijk te leren kennen en er de weg te weten om snel te kunnen focussen op een bepaalde sector van de arbeidsmarkt als een cliënt daarom vraagt.

Daarnaast is een groot netwerk voor iedere loopbaanadviseur van betekenis om de cliënt snel en efficiënt te kunnen adviseren. Een derde factor om de arbeidsmarkt overzichtelijk te houden is om een zekere mate van specialisatie toe te passen, zoals bijvoorbeeld een specialisatie voor de begeleiding van het topsegment van de arbeidsmarkt.

De arbeidsmarktbegeleiding is, naast de psychologische begeleiding, voor de cliënt op zoek naar een nieuwe baan, het belangrijkste werkterrein van de loopbaanadviseur. In het vakgebied loopbaanadvisering worden door Career Management Institute (CMI) twee richtingen onderscheiden: loopbaancoaching en loopbaanbegeleiding.

\footnotetext{
${ }^{1}$ Een baan behoeft niet immer het doel van de begeleiding te zijn. Er zijn ook andere bestemmingen denkbaar, zoals het geven van prioriteit aan gezinsuitbreiding.
} 
In het kader van loopbaanbegeleiding wordt door CMI specifiek outplacement en re-integratie $2^{\text {de }}$ spoor ${ }^{2}$ onderscheiden. De term loopbaanbegeleiding wordt ook gebruikt om de begeleiding van A naar B aan te duiden, zowel binnen als buiten de organisatie. In het algemeen is de psychologische begeleiding de eerste fase van het proces en is de arbeidsmarktbegeleiding de tweede fase van het proces. Voor loopbaanadvisering is de kwaliteit van de arbeidsmarktbegeleiding van primair belang. Tot op heden kent de auteur van dit proefschrift geen onderzoeken die de arbeidsmarktbegeleiding over een breed front belichten. In dit hoofdstuk wordt dossieronderzoek gedaan naar de kwaliteit van de arbeidsmarktbegeleiding op basis van casusvoorbeelden van 150 door CMI te gecertificeerde loopbaanadviseurs. De casusvoorbeelden werden door CMI gevraagd in het kader van 'de kennis en de ontwikkeling van de arbeidsmarkt'.

\subsubsection{Kernoragen}

Om de kwaliteit van de loopbaanadviseur inzake het begeleiden van cliënten bij het betreden van de arbeidsmarkt goed te kunnen beoordelen zullen vier kernvragen gesteld worden.

Veelal werken loopbaanadviseurs met cliënten die zich richten op de externe arbeidsmarkt om een passende baan te vinden. Natuurlijk zijn er ook cliënten die de verandering van werkkring binnen de eigen organisatie zoeken of er, in samenspraak met hun leidinggevende, vanuit gaan dat er verbetering moet komen in de kwaliteit van de uitvoering van de eigen functie. Meestal is het de cliënt er echter

\footnotetext{
${ }^{2}$ Re-integratie 2de spoor: Als in het 1e spoor duidelijk wordt dat een zieke werknemer niet meer bij de huidige werkgever aan de slag kan, dient het $2^{\text {de }}$ spoor te worden opgestart. Dit moet duidelijk terugkomen in het re-integratiedossier. Een arbeidsdeskundige of bedrijfsarts kan aangeven of het nodig is om een $2^{\text {de }}$ spoortraject te starten.
} 
om te doen om een werkkring buiten de eigen organisatie te vinden. De richting van het zoekproces is zeer afhankelijk van vraag en aanbod op de arbeidsmarkt, maar ook van de talenten en vaardigheden van cliënten zelf, alsmede zijn ervaring en genoten opleiding. Er zijn ook loopbaanadviseurs die zich specialiseren. Een voorbeeld daarvan is een specialisatie voor 'hoogbegaafden' of een specialisatie voor 'het topsegment'. De arbeidsmarkt als geheel is echter heel dynamisch waardoor de arbeidsmarktbegeleiding steeds aangepast dient te worden aan de veranderingen die in de tijd plaatsvinden.

De eerste kernvraag is bedoeld om inzicht te krijgen in de verschillende aspecten die een essentiële rol spelen bij de arbeidsmarktbegeleiding. Een voorbeeld van een aspect dat vaak aan bod komt bij het begeleiden van cliënten naar de arbeidsmarkt is het in kaart brengen van de talenten van een cliënt. Te verwachten valt dat daarnaast ook allerlei andere essentiële aspecten aan bod komen. Het doel van dit onderzoek is om te achterhalen aan welke aspecten van arbeidsmarktbegeleiding loopbaanadviseurs aandacht besteden. Het bovenstaande leidt tot de eerste kernvraag:

Kernvraag 1: Welke aspecten van de arbeidsmarktbegeleiding komen aan bod tijdens de arbeidsmarktbegeleiding en aan welke aspecten wordt door de adviseur de meeste aandacht besteed?

De adviseur dient continu de verschillende aspecten van de arbeidsmarkt op peil te houden. Dat is ook de reden dat CMI van de te certificeren loopbaanadviseurs eist dat zij, na gecertificeerd te zijn, zich iedere drie jaar laten re-certificeren. Dit om niet alleen te laten zien dat de loopbaanadviseurs hun vakbekwaamheid behouden hebben, maar ook om te laten zien dat zij hun kennis en kwaliteit van de arbeids- 
marktbegeleiding verder hebben ontwikkeld. Om te achterhalen in hoeverre loopbaanadviseurs aan deze eis voldoen, wordt in dit onderzoek de kwaliteit van de geboden arbeidsmarktbegeleiding onderzocht, wat leidt tot de tweede kernvraag:

Kernvraag 2: Beschikt de loopbaanadviseur over voldoende kwaliteit om de cliënt te begeleiden bij het betreden van de arbeidsmarkt?

In het verlengde van de voorgaande twee kernvragen is het interessant te onderzoeken of de aspecten en de kwaliteit van de arbeidsmarktbegeleiding verschillen over de drie niveaus van bekwaamheid die CMI hanteert. CMI onderscheidt drie niveaus van vakbekwaamheid, die aangeven in welke mate de loopbaanadviseur 'in de breedte' van het vakgebied werkt. Het is denkbaar dat adviseurs die op een breder niveau opereren aandacht schenken aan andere aspecten van arbeidsmarktbegeleiding dan adviseurs die op een smaller niveau werken. Daarnaast richt het onderzoek inzake de drie CMI-niveaus zich ook op de kwaliteit van de arbeidsmarktbegeleiding. Daarbij is de omgang met social media een belangrijk aspect. Gezien het feit dat niveau A veelal de jongste categorie loopbaanadviseurs vertegenwoordigt, zal het A-niveau de meeste kans maken om op het gebied van arbeidsmarktbegeleiding de beste kwaliteit te leveren door hun uitgebreide kennis van de mogelijkheden van social media. Dit leidt tot de derde kernvraag:

Kernvraag 3: Bestaan er verschillen tussen de drie CMI-niveaus in a) de aspecten die aan bod komen tijdens de arbeidsmarktbegeleiding en b) de kwaliteit van de arbeidsmarktbegeleiding? 
Ten slotte is het voor het vakgebied van belang om te onderzoeken of er een relatie bestaat tussen bepaalde achtergrondkenmerken van de loopbaanadviseur en de kwaliteit van de geleverde arbeidsmarktbegeleiding. Het is bijvoorbeeld denkbaar dat een hogere opleiding of meer specifieke werkervaring de kwaliteit van de begeleiding die een adviseur biedt ten goede komt. Daarnaast zouden gender en leeftijd gerelateerd kunnen zijn aan de kwaliteit van de arbeidsmarktbegeleiding. Dit leidt tot de vierde kernvraag:

Kernvraag 4: Is er een relatie tussen de achtergrondvariabelen (gender, leeftijd, opleiding en specifieke werkervaring) van de loopbaanadviseur en de kwaliteit van diens arbeidsmarktbegeleiding?

\subsubsection{Theorie}

Het meten van dienstverlening is lastig, vooral als het gaat om het meten van de kwaliteit van de dienstverlening. Anders dan bij een product is een dienst niet grijpbaar, waardoor het meten van de kwaliteit van de dienst altijd een probleem vormt. De dienst wordt direct geleverd en de kwaliteit ervan kan pas achteraf gemeten worden. Bovendien hebben de cliënten van de geleverde dienst een zekere verwachting, die pas bij het 'consumeren' van de dienst al dan niet uit kan komen. Er kan dus een verschil zijn tussen wat de cliënt verwacht en hetgeen de cliënt ervaart.

Voor de dienstensector is er een aantal, meest Amerikaanse, onderzoekers, die meetinstrumenten ontwikkeld hebben om de kwaliteit van geleverde diensten achteraf te meten. Zeithalm, Parasuraman en Berry (1988) zijn hiervan de meest bekende onderzoekers. $\mathrm{Zij}$ hebben in de jaren tachtig van de vorige eeuw het Servqual-model ontwikkeld, om de kwaliteit van de dienstverlening te kunnen 
meten. Hierin spelen het verwachtingspatroon van de cliënt en (toegepast op het onderhavige onderzoek) de perceptie van de adviseur van dat verwachtingspatroon een belangrijke rol. Veelal zijn afwijkingen hierin te wijten aan afwijkingen van de perceptie van de loopbaanadviseur van het verwachtingspatroon met wat de cliënt wenst. Voor het onderhavige onderzoek is het Servqual-model echter minder geschikt, omdat de specifieke data met betrekking tot verwachtingen voor dit onderzoek ontbreken.

Een andere methode voor het meten van de kwaliteit van de dienstverlening is de Grounded Theory. Glaser en Strauss (1967) hebben in hun boek 'The Discovery of the Grounded Theory' een theorie ontwikkeld voor kwalitatief onderzoek, die zeer geschikt is voor het onderhavige onderzoek. Hieronder zal deze methode van onderzoek nader toegelicht worden.

Deze Grounded Theory (GT) is in feite geen 'theorie', maar een 'methode' van kwalitatief onderzoek, waarbij het uitgangspunt is dat er geen variabelen en verbanden bekend zijn voordat de data onderzocht wordt. Dat is in het onderhavige onderzoek het geval. Daardoor is er exploratief onderzoek nodig om de variabelen die een rol spelen bij arbeidsmarktbegeleiding door classificatie van de bestaande data te benoemen.

De onderwerpen die de basis vormen voor de categorieën die door de classificatie gevormd worden, zullen in het onderhavige onderzoek door de 150 te certificeren loopbaanadviseurs zelf worden aangedragen. Zodoende kunnen de verkregen variabelen en de verbanden gelegd en gemeten worden, hetgeen de kern is van exploratief kwalitatief onderzoek. Voorwaarde voor dit soort onderzoek is dat gewerkt kan worden met een relatief groot databestand. Glaser (1967) noemt nog vier criteria voor het kunnen toepassen van GT: 1) De categorieën dienen voort te komen uit de beschikbare data en niet uit van tevoren bedachte categorieën; 2) Het 
onderzoek dient gedrag te verklaren met betrekking tot een interessegebied in heden en toekomst, zoals in het onderhavige onderzoek de essenties van de arbeidsmarktbegeleiding; 3) Het onderzoek dient te blijven focussen op het aangegeven interessegebied, dus hier op 'de essenties van de arbeidsmarktbegeleiding' en 4) GT heeft het vermogen om continu te veranderen als nieuwe data zich aankondigen, waardoor steeds nieuwe categorieën zich kunnen vormen of categorieën zich kunnen samenvoegen of afvallen. Alle vier criteria werden in het onderhavige onderzoek toegepast tijdens de bepaling van de categorieën.

Deze methode is gericht op de classificatie van data, waarna de kwaliteit per categorie beoordeeld en gemeten kan worden. Zoals de naam al weergeeft werkt GT als een echt bottom-up onderzoek, oftewel 'practice based evidence' onderzoek. Ieder casusvoorbeeld, beginnend bij voorbeeld één, krijgt een herkenbaar kenmerk om de categorie aan te duiden, zoals bijvoorbeeld 'vacaturebeheer'. In de loop van de classificatie volgen er meer casussen met dezelfde classificering. Casussen gaan hierdoor op elkaar lijken, waardoor ze, eventueel met een enigszins aangepaste naam, tot één categorie verenigd worden. De classificatie gaat door, totdat alle casusvoorbeelden zijn geclassificeerd tot categorieën. Door GT wordt aangeraden om per categorie een memo te maken, om het kenmerk van de categorie goed te duiden. Vervolgens worden zo nodig bepaalde categorieën nogmaals verenigd, zodat er een overzienbaar aantal categorieën van voldoende omvang ontstaat. Zeer kleine categorieën kunnen ook afvallen. De GT is derhalve zeer geschikt voor het onderhavige onderzoek naar de kwaliteit van arbeidsmarktbegeleiding van loopbaanadviseurs.

Hierbij een casusvoorbeeld zoals opgesteld door een kandidaat voor certificering als Register Loopbaanadviseur (Ingrid Koster, RL; met toestemming 
afgedrukt; zie Figuur 6.1). De casus werd door de zeven experts als van zeer hoog niveau beoordeeld.

Een van mijn cliënten werkt al bijna 18 jaar bij dezelfde werkgever als postbode en komt bij me met de vraag: wie zit er in deze arbeidsmarkt op mijn kennis en kunde te wachten? En wat zijn mijn kansen gezien mijn leeftijd (>50 jaar) en opleiding (versnipperd; niet meer relevant voor de uiteindelijke zoekrichting)?

Allereerst zijn we een MBO EVC traject gaan inzetten. De arbeidsmarkt vraagt diploma's, en he EVC biedt voor mijn cliënt de perfecte kans zijn ervaring in een erkend certificaat om te zetten. Dit is succesvol verlopen. Tegelijkertijd zijn we de kwaliteiten en vaardigheden van mijn cliënt in kaart gaan brengen. De ideale vervolgstap werd daaruit gedestilleerd. Zijn achtergrond lag ook in de horeca. Dit gecombineerd met zijn dienstverlenende instelling als postbode gaf de richting van een functie met direct in klantencontact aan als hoofdvoorwaarde. Hij kwam uit op een aantal opties en samen besloten we dat de meest realistische kans lag bij personenvervoer. Men is nl. daar juist niet op zoek naar jongeren met nog weinig levenservaring. We zijn op zoek gegaan naar een werkgever die een interne opleiding en liefst dan ook een baangarantie biedt. Dat werd het GVB in A'dam. Op dit moment is Berrie in een zeer ver gevorderd stadium om trambestuurder te worden en volgt de interne opleiding.'

Figuur 6.1. Casusvoorbeeld arbeidsmarktbegeleiding, opgesteld door Ingrid Koster, RL.

\subsubsection{Opbouw van het hoofdstuk}

De verdere opbouw van dit hoofdstuk is als volgt: in paragraaf 6.2 zal de methodiek van het onderhavige onderzoek uitgewerkt worden door in te gaan op het design, de dataverzameling, de steekproef en de meetinstrumenten. In paragraaf 6.3 zullen de resultaten per kernvraag uitgewerkt worden, waarna in de discussieparagraaf 6.4 de conclusies besproken worden, die zullen leiden tot discussie en aanbevelingen. 


\subsection{Methodiek}

\subsubsection{Design}

De genoemde 150 casusvoorbeelden inzake de arbeidsmarktbegeleiding waren afkomstig uit CMI-dossiers van 150 gecertificeerde loopbaanadviseurs uit de periode 2012 - 2014. De te certificeren adviseurs kregen van CMI de opdracht om een casusvoorbeeld te schrijven over de toepassing van arbeidsmarktkennis bij de begeleiding van één van hun cliënten. De opdracht luidde: "De loopbaanprofessional heeft een breed overzicht van de arbeidsmarkt en van huidige en toekomstige arbeidsmarktontwikkelingen. In het voorbeeld is het de bedoeling dat de kandidaat laat zien hoe hij/zij deze kennis toepast en welke afweging gemaakt werd om tot dit professionele advies te komen (zelfreflectie)." In de opdracht van CMI zijn de kandidaten voor certificering vrij om een keuze te maken van het onderwerp dat zij zouden willen behandelen om te laten zien dat zij een 'breed overzicht van de arbeidsmarkt en de ontwikkeling van de arbeidsmarkt' hebben.

Vervolgens werden op basis van de GT-methode door de auteur van dit proefschrift negen categorieën benoemd, die de voorkeur van de kandidaten voor certificering bleken te hebben, rond het centrale thema 'de essenties van arbeidsmarktbegeleiding', waarin de 150 casusvoorbeelden werden ondergebracht. De negen categorieën, die ter keuze aan de beoordelaars werden voorgelegd, waren de volgende:

1) Talenten in kaart brengen voor de volgende stap in de arbeidsmarkt: Dit omvat dat de adviseur in de beginfase van de begeleiding met de cliënt onderzoekt welke talenten de cliënt in huis heeft die passend zijn voor de volgende stap van de cliënt in de arbeidsmarkt. Door deze begeleiding is het de bedoeling dat de cliënt zijn talenten zelf onderkent en gaat gebruiken; 
2) Gebruikmaken van de verandering in vraag en/of aanbod op de arbeidsmarkt: Dit omvat dat de adviseur aan de cliënt laat zien hoe vraag en aanbod op de arbeidsmarkt kunnen veranderen en hoe de cliënt daarvan gebruik kan maken om een passende baan te verwerven;

3) Inzetten van het eigen netwerk en sociale media: Dit omvat dat de adviseur aan de cliënt laat zien hoe het eigen netwerk van de cliënt en social media ingezet kunnen worden om geschikte vacatures te vinden om vervolgens een passende baan te verkrijgen;

4) Inzetten regio- en sectorenkennis: Dit betreft het inzetten van kennis over relevante regio's door de adviseur, waardoor de cliënt effectief begeleid kan worden in de arbeidsmarkt;

5) Vacaturebeheer inzetten: Dit betreft het geven van aanwijzingen door de adviseur over hoe de cliënt vacatures kan vinden en hierop kan reageren;

6) Vertaling maken van de wensen van de cliënt naar de mogelijkheden op de arbeidsmarkt: Dit omvat het maken van een vertaalslag door de adviseur van wat de cliënt wenst en wat de arbeidsmarkt op het gebied van deze wensen te bieden heeft;

7) Employability 3 als instrument voor arbeidsmarktbegeleiding inzetten: Employability is onder meer de bekwaamheid van de cliënt om de eigen weg te zoeken op de arbeidsmarkt. Het werk van de adviseur is om die eigen weg samen met de cliënt te verkennen;

8) Goede communicatie met werkgevers bewerkstelligen: Dit omvat vaak goede training, waardoor de cliënt de communicatie met de werkgevers beter aankan;

\footnotetext{
${ }^{3}$ Employability is volgens de Dikke van Dale: "de bekwaamheid van een individu om haar of zijn eigen weg te zoeken op de arbeidsmarkt; en bovendien dat het individu aantrekkelijk wordt of blijft voor de arbeidsmarkt."
} 
9) Geen professioneel voorbeeld: Met deze categorie konden de experts (zie hieronder voor uitleg) de casusvoorbeelden classificeren als zij van mening zijn dat de casus geen goed voorbeeld van professioneel handelen is.

Vervolgens werden de casusvoorbeelden beoordeeld door zeven experts, die uit bovengenoemde negen categorieën een keuze moesten maken. Zij waren allen mentoren dan wel bestuursleden van CMI. De beoordelende experts werden in drie groepen van twee ingedeeld, waardoor zij ieder slechts een derde van de 150 voorbeelden voor hun rekening behoefden te nemen. Daarnaast beoordeelde de auteur van dit proefschrift als derde expert alle 150 casusvoorbeelden.

Alle casusvoorbeelden waarover consensus bestond (minimaal twee van de drie experts dienden daarvoor eenzelfde categorie te hebben aangewezen), werden vervolgens nogmaals aan dezelfde groep beoordelende experts voorgelegd. Aan hen werd gevraagd om deze met consensus geclassificeerde casusvoorbeelden nu ook op kwaliteit te beoordelen.

\subsubsection{Steekproef}

De dossiers van 150 kandidaten voor certificering tot Register Loopbaanadviseur (RL) vormden de basis van dit onderzoek. Alle dossiers werden door de loopbaanadviseurs opgesteld in de periode 2012 - 2014. Voor niveau A werden 33 casusvoorbeelden (22\%) geteld, voor niveau B 90 casusvoorbeelden (60\%) en voor niveau C 27 casusvoorbeelden (18\%). De gemiddelde leeftijd van de 150 loopbaanadviseurs die aan de steekproef deelnamen was circa 50 jaar $(S D=6,4)$. In de steekproef waren vrouwen in de meerderheid, te weten: 108 van de 150 loopbaanadviseurs. Dat is $72 \%$. De loopbaanadviseurs hadden allen een hbo-opleiding (67\%) of een wo-opleiding (33\%), maar niet noodzakelijkerwijs een opleiding in 
loopbaanadvisering. De gemiddelde specifieke werkervaring was 13 jaar, met een $S D$ van 3,5 jaar. Tabel 6.1 geeft een overzicht van de achtergrondvariabelen van de loopbaanadviseurs in de steekproef, uitgesplitst naar CMI-niveau.

Tabel 6.1

Achtergrondvariabelen van de loopbaanadviseurs, uitgesplitst naar CMI-niveau.

\begin{tabular}{|c|c|c|c|c|c|c|c|}
\hline \multirow{2}{*}{$\begin{array}{l}\text { CMI- } \\
\text { niveau }\end{array}$} & \multirow[t]{2}{*}{$\mathrm{N}$} & \multicolumn{2}{|c|}{ Gender } & \multicolumn{2}{|c|}{ Opleiding } & $\begin{array}{c}\text { Leeftijd } \\
\text { in jaren } \\
\text { (gem) }\end{array}$ & $\begin{array}{c}\text { Specifieke } \\
\text { werkervaring } \\
\text { in jaren (gem) }\end{array}$ \\
\hline & & V & $\mathrm{M}$ & hbo & wo & $M$ & $M$ \\
\hline Niveau A & 33 & 22 & 11 & 21 & 12 & 50 & 9 \\
\hline Niveau B & 90 & 71 & 19 & 68 & 22 & 49 & 13 \\
\hline Niveau C & 27 & 15 & 12 & 15 & 12 & 53 & 17 \\
\hline Totaal & 150 & 108 & 42 & 101 & 49 & $\begin{array}{c}50 \\
(S D=6,4)\end{array}$ & $\begin{array}{c}13 \\
(S D=3,5)\end{array}$ \\
\hline
\end{tabular}

\subsubsection{Meetinstrumenten}

Classificering: Op basis van de GT-methode werden de casusvoorbeelden in een aantal bruikbare categorieën geclassificeerd, uitgaande van de essenties van de arbeidsmarktbegeleiding als centraal thema. In de instructie voor het gebruik van GT wordt vermeld dat kleine categorieën (te denken valt aan een categorie met één of twee voorbeelden) kunnen worden verwijderd. Van de 155 oorspronkelijke casusvoorbeelden werden daarom vijf voorbeelden geschrapt. Dat waren twee voorbeelden waarbij een extra opleiding leidde tot passend werk; een van thema- 
tisch netwerken en twee van duurzame inzetbaarheid. Ook werd voor iedere categorie een memo geschreven om de categorie binnen het geheel van de categorievorming te kunnen beschrijven.

Beoordeling voorkeurscategorie: Aan de zeven beoordelaars werd vervolgens gevraagd om ieder casusvoorbeeld in één van de negen categorieën te plaatsen. De vraag aan de experts was: "Wilt $\mathrm{u}$ aan de hand van onderstaande lijst categorieën alle bijgaande 50 casusvoorbeelden beoordelen en in één van de negen categorieën plaatsen?" Indien twee van de drie of drie van de drie experts een casusvoorbeeld in dezelfde categorie plaatsten, werd dit voor dit onderzoek opgevat als consensus. Geen van de zeven beoordelaars had moeite om alle aan hem of haar toevertrouwde 50 casusvoorbeelden in één van de door de auteur van dit proefschrift geclassificeerde categorieën te plaatsen. De negen categorieën waren derhalve voldoende om alle casusvoorbeelden te plaatsen.

Beoordeling van de kwaliteit: Aan dezelfde experts werd vervolgens gevraagd om de kwaliteit te beoordelen van de casusvoorbeelden waarover tussen minimaal twee van de drie experts consensus bestond over de best passende categorie. Casusvoorbeelden waarvoor deze consensus ontbrak werden verder buiten beschouwing gelaten. De exacte vraagstelling hiervoor was: "Wilt $u$ de navolgende casusvoorbeelden nu op kwaliteit beoordelen, op een Likertschaal waarbij 1 een zeer lage en 5 een zeer hoge kwaliteit is?" In het onderhavige onderzoek werden casusvoorbeelden die op een vijfpuntsschaal een score van 3, 4 of 5 hadden gekregen, als 'kwalitatief voldoende' $(\geq 3,0)$ beschouwd.

\footnotetext{
${ }^{4}$ De auteur van dit proefschrift was als onderzoeker en expert in het kader van G.T. vrij om vanuit zijn ervaring aan te geven met welke voorkeuren de te certificeren adviseurs de casusvoorbeelden hebben geschreven. Deze voorkeuren werden door de auteur van dit proefschrift in categorieën ingedeeld en aan de zeven experts aangeboden ter beoordeling op categorie en vervolgens op kwaliteit.
} 


\subsection{Resultaten}

De resultaten werden bereikt door de vier kernvragen te onderzoeken. Kernvraag 1 luidde: Welke aspecten van de arbeidsmarktbegeleiding komen aan bod tijdens de arbeidsmarktbegeleiding en aan welke aspecten wordt door adviseurs de meeste aandacht besteed?

Indeling casusvoorbeelden in categorieën

Voor de resultaten van de drie groepen experts wordt in Tabel 6.2 een overzicht van de consensus tussen de (twee of drie) experts over de meest geschikte categorie voor elk casusvoorbeeld weergegeven (per groep en in totaal). Over 106 van de 150 casusvoorbeelden was er consensus tussen twee of drie van de experts over de categorie waarin het casusvoorbeeld het beste paste (71\%), waarvan 17 voorbeelden $(11 \%)$ door alle drie beoordelaars in dezelfde categorie werden geplaatst. Tien voorbeelden $(7 \%)$ werden in categorie negen (geen professionele casus) geplaatst. Er bleek geen consensus te zijn tussen de experts over 44 (29\%) van de casusvoorbeelden.

Tabel 6.2

Overzicht beoordeling van consensus over voorkeurscategorieën per groep.

\begin{tabular}{lcccc}
\hline $\begin{array}{c}\text { Groep } \\
(N=150)\end{array}$ & Geen & Consensus & Consensus & Totaal \\
consensus & $2 x$ & $3 x$ & consensus \\
\hline Groep 1 & 14 & 25 & 11 & $36(34 \%)$ \\
Groep 2 & 19 & 23 & 8 & $3129 \%)$ \\
Groep 3 & 11 & 36 & 3 & $39(37 \%)$ \\
\hline Totaal & 44 & 84 & 22 & $106(100 \%)$ \\
\hline
\end{tabular}




\section{Hiërarchie van categorieën van arbeidsmarktbegeleiding}

Na het uitzoeken van de mate van consensus tussen de experts over de casusvoorbeelden werd onderzocht hoe vaak alle categorieën door de adviseurs genoemd waren. In Tabel 6.3 wordt een overzicht gegeven van de categorieën waar de voorkeur van de te certificeren loopbaanadviseurs naar uit ging om er een casusvoorbeeld aan te wijden. De drie categorieën waarvan de adviseurs de meeste voorbeelden gaven waren: 1) 'Het gebruik van eigen netwerk en sociale media' (22x); 2) 'Sectoren en regio's inzetten voor passend werk' (20x); en 3) 'Verandering in vraag en/of aanbod op de arbeidsmarkt' (16x).

Kernvraag 1 kan derhalve als volgt beantwoord worden: door middel van GT werden negen categorieën opgesteld, die aan bod kwamen in de vorm van categorieën die tijdens de arbeidsmarktbegeleiding gebruikt werden. Van deze casusvoorbeelden werd door de loopbaanadviseurs de meeste aandacht besteed aan 1) gebruikmaken van het eigen netwerk en sociale media; 2) inzetten van regio- en sectorkennis en 3) gebruik maken van vraag en aanbod'. Deze drie voorkeurscategorieën werden in totaal 58 keer met consensus ingezet. Dat is bijna 55\% van de met consensus beoordeelde casusvoorbeelden.

Kernvraag 2 luidde: Beschikt de loopbaanadviseur over voldoende kwaliteit om de cliënt te begeleiden bij het betreden van de arbeidsmarkt? Om te achterhalen of de loopbaanadviseur over voldoende kwaliteit beschikt werden de 106 casusvoorbeelden waarover consensus bestond met betrekking tot categorie tussen minimaal twee van de drie experts, door diezelfde experts op kwaliteit beoordeeld. 
Tabel 6.3

Hiërarchie van de voorkeurscategorieën van met consensus beoordeelde casusvoorbeelden, volgens GT.

\begin{tabular}{|c|c|c|}
\hline Hiërarchie & Voorkeurscategorieën & $\begin{array}{c}\text { Met } \\
\text { consensus } \\
\text { beoordeeld }\end{array}$ \\
\hline 1 & $\begin{array}{l}\text { Gebruikmaken van eigen netwerk en sociale media in de } \\
\text { arbeidsmarkt }\end{array}$ & $22 \times$ \\
\hline 2 & Inzetten regio- en sectoren kennis & $\begin{array}{c}20 \times \\
(19 \%)\end{array}$ \\
\hline 3 & $\begin{array}{l}\text { Gebruikmaken verandering in vraag en/of aanbod op de } \\
\text { arbeidsmarkt }\end{array}$ & $\begin{array}{c}16 \mathrm{x} \\
(15 \%)\end{array}$ \\
\hline 4 & $\begin{array}{l}\text { Talenten in kaart brengen voor de volgende stap in de } \\
\text { arbeidsmarkt }\end{array}$ & $\begin{array}{c}11 \times \\
(10 \%)\end{array}$ \\
\hline 5 & $\begin{array}{l}\text { Vertaling maken van de wensen van de cliënt in de } \\
\text { arbeidsmarkt }\end{array}$ & $\begin{array}{l}9 x \\
(8 \%)\end{array}$ \\
\hline 6 & $\begin{array}{l}\text { Employability als instrument voor loopbaan coaching } \\
\text { inzetten }\end{array}$ & $\begin{array}{l}9 x \\
(8 \%)\end{array}$ \\
\hline 7 & Goede communicatie met werkgevers & $\begin{array}{c}7 x \\
(7 \%)\end{array}$ \\
\hline 8 & Vacaturebeheer inzetten & $\begin{array}{c}2 x \\
(2 \%)\end{array}$ \\
\hline 9 & Geen professioneel voorbeeld vastgesteld & $\begin{array}{c}10 \mathrm{x} \\
(10 \%)\end{array}$ \\
\hline & Totaal aantal voorkeurscategorieën met consensus & $\begin{array}{c}106 x \\
(100 \%)\end{array}$ \\
\hline
\end{tabular}

Tabel 6.4 geeft een overzicht van de kwaliteit van de 106 casusvoorbeelden die met consensus op categorie werden beoordeeld. Daarbij werd de kwaliteit als voldoende beoordeeld als de casusvoorbeelden met minimaal twee scores 3 of 4 of 
5 op de vijfpuntsschaal beoordeeld werden. Het bleek dat het aantal op kwaliteit beoordeelde casusvoorbeelden 77 bedroeg. Dat is $72 \%$ van de 106 met consensus geplaatste casusvoorbeelden, maar slechts $51 \%$ van de oorspronkelijke 150 casusvoorbeelden.

De kwaliteit werd tevens op basis van gemiddelden onderzocht: het onderzoek werd verricht door voor alle casusvoorbeelden de gemiddelde score te berekenen. Ook voor dit onderzoek is gekozen om alleen casusvoorbeelden die op de vijfpuntsschaal gemiddeld tussen 3 en 5 scoorden voor voldoende kwaliteit mee te nemen in de berekening. Er waren 86 van de 150 (57\%) casusvoorbeelden met een gemiddelde beoordeling tussen 3 en 5 .

Tabel 6.4

Overzicht van de op kwaliteit beoordeelde casusvoorbeelden die met consensus in een van de categorieën werden ingedeeld, beoordeeld door de drie expertgroepen.

\begin{tabular}{lccccc}
\hline & $\begin{array}{c}\text { Schaal } \\
(1-5)\end{array}$ & $\begin{array}{c}\text { Groep 1 } \\
(N=36)\end{array}$ & $\begin{array}{c}\text { Groep 2 } \\
(N=31)\end{array}$ & $\begin{array}{c}\text { Groep 3 } \\
(N=39)\end{array}$ & $\begin{array}{c}\text { Totaal } \\
(N=106)\end{array}$ \\
\hline Totaal beoordeeld op & $3-5$ & 16 & 31 & 30 & 77 \\
kwaliteit: 3 - 5, minimaal & & & & \\
twee 'voldoende' scores & & & & \\
door twee beoordelaars & & & & \\
\hline Onvoldoende kwaliteit: & $1-2$ & 20 & & \\
geen twee dezelfde scores & & & & & \\
op kwaliteit beoordeeld & & & & & \\
\hline
\end{tabular}

Kernvraag 3a luidde: Bestaan er verschillen tussen de drie CMI-niveaus van de loopbaanadviseurs in de aspecten die aan bod komen tijdens de arbeidsmarktbegeleiding? In Tabel 6.5 wordt allereerst onderzocht hoe de consensus 
bijdraagt aan de kwaliteit. Het blijkt dat voor CMI-niveau A slechts $51 \%$ consensus behaalde inzake categorie. Voor CMI-niveau B was dat 79\%, terwijl voor CMIniveau C $67 \%$ consensus behaalde op categorie.

Zoals Tabel 6.5 aangeeft is ook de relatieve frequentie per categorie per CMIniveau aangegeven. Van de negen categorieën kwam op CMI-niveau A de categorie 'gebruikmaken van het eigen netwerk en sociale media' het meest aan bod, te weten $21 \%$. Van de negen categorieën kwam op CMI-niveau B de categorie 'inzetten van regio- en sectorkennis" het meest aan bod, met 16\%, en op CMI-niveau C kwam de categorie 'gebruikmaken van verandering in vraag en/of aanbod' het meest aan bod, met $19 \%$. Er bestaan derhalve relatieve verschillen in welke categorieën aan bod komen op de drie CMI-niveaus.

Kernvraag 3b luidde: Bestaan er verschillen tussen de drie CMI-niveaus in de kwaliteit van de arbeidsmarktbegeleiding? De berekening op basis van een Anova laat zien dat er een marginaal verschil tussen de drie niveaus bestaat: $F(105,2)=3,00$; $p<0,10$. De gemiddelde kwaliteit van de casusvoorbeelden op de verschillende niveaus verschilt marginaal, namelijk: op niveau A: $M=3,01$; op niveau $\mathrm{B}: M=3,62$ en op niveau C: $M=3,67$. Daarmee blijkt de arbeidsmarktbegeleiding van de kandidaten voor CMI-certificering op niveau A van mindere kwaliteit dan bij de kandidaten van niveau B en C.

Op basis van ANOVA blijkt vervolgens dat alleen het verschil tussen niveau A en niveau B significant is, namelijk: $p<0,05$, maar die tussen $A$ en $C$ niet en die tussen B en C ook niet, namelijk respectievelijk $p=0,11$ en $p=0,99$. (Het feit dat het verschil tussen niveau $A$ en $C$ niet significant is, terwijl de gemiddelden van $A$ en $C$ verder uit elkaar liggen dan A en B, bevreemdt enigszins. Dit wordt mogelijk veroorzaakt doordat de frequenties (aantallen casusvoorbeelden) van de niveaus $\mathrm{A}$ en $C$ vrij laag zijn (respectievelijk $N=17$ en 18), terwijl de frequentie van de 
Tabel 6.5

Verschillen tussen de drie CMI-niveaus inzake aspecten van de arbeidsmarktbegeleiding en volgorde van belangrijkheid na consensus over categorie.

\begin{tabular}{|c|c|c|c|c|}
\hline Voorkeurscategorie & $\begin{array}{c}\text { CMI- } \\
\text { niveau A }\end{array}$ & $\begin{array}{c}\text { CMI- } \\
\text { niveau B }\end{array}$ & $\begin{array}{c}\text { CMI- } \\
\text { niveau C }\end{array}$ & Totaal \\
\hline Geen consensus over categorie & $\begin{array}{c}16 \\
(49 \%)\end{array}$ & $\begin{array}{c}19 \\
(21 \%)\end{array}$ & $\begin{array}{c}9 \\
(33 \%)\end{array}$ & $\begin{array}{c}44 \\
(29 \%)\end{array}$ \\
\hline $\begin{array}{l}\text { Talenten in kaart brengen voor } \\
\text { volgende stap }\end{array}$ & $\begin{array}{c}1 \\
(3 \%)\end{array}$ & $\begin{array}{c}9 \\
(10 \%)\end{array}$ & $\begin{array}{c}1 \\
(4 \%)\end{array}$ & $\begin{array}{c}11 \\
(7 \%)\end{array}$ \\
\hline $\begin{array}{l}\text { Gebruik verandering in vraag en } \\
\text { of aanbod }\end{array}$ & $\begin{array}{c}0 \\
(0 \%)\end{array}$ & $\begin{array}{c}11 \\
(12 \%)\end{array}$ & $\begin{array}{c}5 \\
(19 \%)\end{array}$ & $\begin{array}{c}16 \\
(11 \%)\end{array}$ \\
\hline $\begin{array}{l}\text { Gebruik van eigen netwerk en } \\
\text { sociale media }\end{array}$ & $\begin{array}{c}7 \\
(21 \%)\end{array}$ & $\begin{array}{c}12 \\
(13 \%)\end{array}$ & $\begin{array}{c}4 \\
(14 \%)\end{array}$ & $\begin{array}{c}23 \\
(15 \%)\end{array}$ \\
\hline Inzetten regio- en sectorenkennis & $\begin{array}{c}4 \\
(12 \%)\end{array}$ & $\begin{array}{c}14 \\
(16 \%)\end{array}$ & $\begin{array}{c}1 \\
(4 \%)\end{array}$ & $\begin{array}{c}19 \\
(13 \%)\end{array}$ \\
\hline Vacaturebeheer inzetten & $\begin{array}{c}0 \\
(0 \%)\end{array}$ & $\begin{array}{c}1 \\
(1 \%)\end{array}$ & $\begin{array}{c}1 \\
(4 \%)\end{array}$ & $\begin{array}{c}2 \\
(1 \%)\end{array}$ \\
\hline $\begin{array}{l}\text { Vertaling maken van de wensen } \\
\text { van de cliënt }\end{array}$ & $\begin{array}{c}2 \\
(6 \%)\end{array}$ & $\begin{array}{c}5 \\
(6 \%)\end{array}$ & $\begin{array}{c}2 \\
(7 \%)\end{array}$ & $\begin{array}{c}9 \\
(6 \%)\end{array}$ \\
\hline $\begin{array}{l}\text { Employability als instrument } \\
\text { inzetten }\end{array}$ & $\begin{array}{c}2 \\
(6 \%)\end{array}$ & $\begin{array}{c}5 \\
(6 \%)\end{array}$ & $\begin{array}{c}2 \\
(7 \%)\end{array}$ & $\begin{array}{c}9 \\
(6 \%)\end{array}$ \\
\hline $\begin{array}{l}\text { Goede communicatie } \\
\text { bewerkstelligen }\end{array}$ & $\begin{array}{c}0 \\
(0 \%)\end{array}$ & $\begin{array}{c}7 \\
(8 \%)\end{array}$ & $\begin{array}{c}1 \\
(4 \%)\end{array}$ & $\begin{array}{c}8 \\
(5 \%)\end{array}$ \\
\hline Geen professioneel voorbeeld & $\begin{array}{c}1 \\
(3 \%)\end{array}$ & $\begin{array}{c}7 \\
(8 \%)\end{array}$ & $\begin{array}{c}1 \\
(4 \%)\end{array}$ & $\begin{array}{c}9 \\
(7 \%)\end{array}$ \\
\hline Totaal & $\begin{array}{c}33 \\
(100 \%)\end{array}$ & $\begin{array}{c}90 \\
(100 \%)\end{array}$ & $\begin{array}{c}27 \\
(100 \%)\end{array}$ & $\begin{array}{c}150 \\
(100 \%)\end{array}$ \\
\hline
\end{tabular}


casusvoorbeelden op niveau $\mathrm{B}$ veel hoger is $(N=71))$. Daarmee kan kernvraag $3 \mathrm{~b}$ bevestigend beantwoord worden: er bestaan inderdaad verschillen in niveau van arbeidsmarktbegeleiding tussen de drie CMI-niveaus, waarbij de begeleiding door adviseurs op niveau A van marginaal significant lagere kwaliteit is dan die door adviseurs op niveau $B$.

Kernvraag 4 luidde: Is er een relatie tussen de achtergrondvariabelen (gender, leeftijd, opleiding en specifieke werkervaring) van de loopbaanadviseur en de kwaliteit van diens arbeidsmarktbegeleiding? Om de relatie tussen de achtergrondkenmerken van de loopbaanadviseurs en de kwaliteit van hun arbeidsmarktbegeleiding te onderzoeken, werden er Spearman's en Pearson's correlatietests toegepast. Deze tests werden uitgevoerd met alleen de 106 casusvoorbeelden waarover consensus bestond.

Gender: Op basis van een Spearman's correlatieanalyse (met dummy codering, waarbij $0=$ man en $1=$ vrouw) bleek dat er een significante correlatie was tussen gender van de loopbaanadviseur en kwaliteit van de arbeidsmarktbegeleiding, namelijk $r h o=0,19(p<0,05)$. Dat wil zeggen dat de arbeidsmarktbegeleiding door vrouwelijke loopbaanadviseurs over het algemeen als kwalitatief iets hoger werd beoordeeld dan die van mannelijke adviseurs.

Leeftijd: Op basis van Pearson's correlatie bleek er geen correlatie te zijn tussen de leeftijd van de adviseur en de kwaliteit van de arbeidsmarktbegeleiding $(r=-0,02$; $p=0,81)$.

Opleiding: de resultaten van een Spearman's correlatieanalyse toonden aan dat er slechts een marginaal significante relatie was tussen het opleidingsniveau van de adviseur en de kwaliteit van diens arbeidsmarktbegeleiding: $r=0,15$ en $p<0,10$. Dit houdt in dat de kwaliteit van de arbeidsmarktbegeleiding van de wo-opgeleide 
loopbaanadviseurs als van iets hogere kwaliteit werd beoordeeld dan die van de adviseurs met een hbo-opleiding.

Specifieke werkervaring: Op basis van Pearson's correlatieanalyse bleek er geen correlatie $(r=-0,00 ; p=0,97)$ te zijn tussen de specifieke werkervaring van de adviseurs en de kwaliteit van hun arbeidsmarktbegeleiding. Dat betekent dat er geen verschil in kwaliteit was tussen adviseurs met meer specifieke ervaring en adviseurs met minder ervaring.

\subsection{Discussie}

\subsubsection{Bevindingen}

In de inleiding van dit hoofdstuk werd reeds geconstateerd dat de arbeidsmarktbegeleiding, naast de psychologische begeleiding, het belangrijkste werkterrein van de loopbaanadviseur is. Uit de in dit hoofdstuk gepresenteerde analyses kunnen de volgende conclusies worden getrokken: 1) De loopbaanadviseurs blijken gemiddeld over net niet voldoende kwaliteit te beschikken om de cliënt goed te begeleiden bij het betreden van de arbeidsmarkt; 2) De kwaliteit van de arbeidsmarktbegeleiding door de loopbaanadviseurs op CMI-niveau A blijkt lager te zijn dan die van adviseurs op niveau B; 3) De arbeidsmarktbegeleiding door vrouwelijke loopbaanadviseurs is gemiddeld iets beter dan die van mannelijke adviseurs; 4) De arbeidsmarktbegeleiding door loopbaanadviseurs met een wo-opleiding is gemiddeld iets beter dan die van adviseurs met een hbo-opleiding. De verdere bevindingen zijn als volgt:

Kernvraag 1 luidde: Welke aspecten van de arbeidsmarktbegeleiding komen aan bod tijdens de arbeidsmarktbegeleiding en aan welke aspecten wordt door adviseurs de meeste aandacht besteed? De drie meest voorkomende aspecten van de arbeidsmarktbegeleiding bleken te zijn: 1) Gebruikmaken van eigen netwerk 
en sociale media in de arbeidsmarkt; 2) Inzetten van regio- en sectorkennis; 3) Verandering in vraag en/of aanbod op de arbeidsmarkt. Deze drie categorieën omvatten tezamen net iets meer dan $50 \%$ van de met consensus beoordeelde casusvoorbeelden. De categorie 'talenten in kaart brengen voor een volgende stap in de arbeidsmarkt' hoort, naar het oordeel van de auteur van dit proefschrift, als categorie minder thuis onder voorbeelden van arbeidsmarktbegeleiding, maar meer onder talentontwikkeling als deel van de psychologische begeleiding.

Kernvraag 2 luidde: Beschikt de loopbaanadviseur over voldoende kwaliteit om de cliënt te begeleiden bij het betreden van de arbeidsmarkt? Bij slechts iets meer dan de helft van de 106 op kwaliteit beoordeelde casusvoorbeelden wordt de kwaliteit met minimaal een voldoende beoordeeld door minimaal twee beoordelaars. 29 casusvoorbeelden blijken niet te voldoen aan deze kwaliteitseis, waardoor er 77 casusvoorbeelden zijn die met voldoende kwaliteit beoordeeld worden. Dat is $51 \% 5$ van de oorspronkelijke steekproef. Voor voldoende zou $>60 \%$ behaald dienen te worden. Derhalve beschikken de loopbaanadviseurs in het algemeen niet over voldoende kwaliteit om de cliënt te begeleiden bij het betreden van de arbeidsmarkt.

Kernvraag 3a luidde: Bestaan er verschillen tussen de drie CMI-niveaus in de aspecten die aan bod komen tijdens de arbeidsmarktbegeleiding? Zoals de resultaten-paragraaf aangeeft is het relatieve aantal voorbeelden per categorie per CMI-niveau daarvoor een goede graadmeter. Van de negen categorieën op CMIniveau A kwam 'gebruikmaken van het eigen netwerk en sociale media' met $21 \%$ het meest aan bod. Op CMI-niveau B kwam 'inzetten van sector- en regiokennis' met $16 \%$ het meest aan bod, terwijl op CMI-niveau C'gebruikmaken van verandering in

\footnotetext{
${ }_{5}^{5} 51 \%$ van de oorspronkelijke steekproef van 150 casusvoorbeelden werd behaald door de casusvoorbeelden met consensus op categorie ook op kwaliteit te beoordelen. Als het gemiddelde van alle 150 casusvoorbeelden onderzocht wordt, die beoordeeld worden $>3.0$ is het resultaat $57 \%$ en dus eveneens net niet voldoende.
} 
vraag en/of aanbod' met 19\% het meest aan bod kwam. Dat er verschillen tussen de drie CMI-niveaus in de aspecten die aan bod komen tijdens de arbeidsmarktbegeleiding is hiermede aangetoond.

Kernvraag 3b luidde: Bestaan er verschillen tussen de drie CMI-niveaus in de kwaliteit van de arbeidsmarktbegeleiding? De kwaliteitsverschillen van de 106 casusvoorbeelden zijn verder onderzocht. Het blijkt dat de kwaliteit van niveau A aanzienlijk lager is dan de kwaliteit van niveau B en C. Het verschil tussen niveau A en $C$ en tussen niveau B en C zijn evenwel niet significant, waarschijnlijk doordat de frequentie bij zowel CMI-niveau A als C klein zijn in vergelijking met niveau B.

Kernvraag 4 luidde: Is er een relatie tussen de achtergrondvariabelen (gender, leeftijd, opleiding en specifieke werkervaring) van de loopbaanadviseur en de kwaliteit van diens arbeidsmarktbegeleiding?

Gender: Zoals reeds bleek, scoren vrouwelijke adviseurs over het algemeen iets beter op kwaliteit van de arbeidsmarktbegeleiding dan mannelijke adviseurs. Dat verbaast enigszins omdat vrouwelijke adviseurs, naar het oordeel van de onderzoeker, zich veelal tot de beroepsgroep aangetrokken voelen door de psychologische begeleiding van de cliënt en niet zozeer voor de arbeidsmarktbegeleiding.

Opleiding: In het kader van opleiding blijken wo-opgeleide loopbaanexperts op basis van de kwaliteit van de van arbeidsmarktbegeleiding marginaal beter te scoren dan hbo-opgeleide adviseurs. Gezien het geringe verschil in kwaliteit met betrekking tot de begeleiding naar de arbeidsmarkt is het verschil in opleiding blijkbaar niet significant. Die constatering is bij de keuze van Job-Hunters (meest hbo-opgeleid) van belang. Wo-opgeleide adviseurs kunnen, vanwege het verschil in beloning, beter op andere (beleid)functies binnen de organisatie ingezet worden. 
Leeftijd: Ook bleek er geen samenhang te zijn tussen de kwaliteit van de arbeidsmarktbegeleiding en de leeftijd van de adviseur. Omdat de ervaring van de loopbaanadviseurs erg kan verschillen gezien loopbaanadvisering voor velen een tweede carrière stap inhoudt, is het feit dat er geen samenhang is, niet onlogisch. Dat zal mogelijk veranderen als loopbaanadviseurs jonger instappen.

Specifieke werkervaring: In dit onderzoek werd ook geen samenhang gevonden tussen kwaliteit van de arbeidsmarktbegeleiding en specifieke werkervaring van de loopbaanadviseur. Dit is opmerkelijk, aangezien er wel een verband werd gevonden tussen kwaliteit van de begeleiding en het CMI-niveau van de adviseur, en het feit dat CMI-niveau van een adviseur onder andere gebaseerd is op aantal jaren specifieke werkervaring. Derhalve zou er juist wel een relatie moeten zijn tussen de specifieke ervaring op de verschillende CMI-niveaus en de kwaliteit van de begeleiding. De uitkomsten van kernvraag 3 en kernvraag 4 spreken elkaar derhalve schijnbaar tegen.

Resumerend is er wel een relatie van kwaliteit van de arbeidsmarktbegeleiding met de achtergrondvariabelen gender en opleiding, maar niet met de achtergrondvariabele leeftijd. Ook is er geen samenhang tussen specifieke werkervaring en de kwaliteit van arbeidsmarktbegeleiding, terwijl er wel een significante samenhang is tussen CMI-niveau met werkervaring, zoals in Tabel 6.1 is aangegeven. Kernvraag 4 kan derhalve gedeeltelijk positief beantwoord worden, maar er is nader onderzoek nodig om te onderzoeken waarom er wel een significant verschil is tussen de kwaliteit van de arbeidsmarktbegeleiding en de drie CMIniveaus, terwijl er geen significant verschil is tussen specifieke werkervaring en de kwaliteit van arbeidsmarktbegeleiding, 


\subsubsection{Conclusies}

Van de 150 casusvoorbeelden werden 106 voorbeelden met consensus in een voorkeurscategorie (de voorkeur van de te certificeren adviseurs) geplaatst. Dat betekent dat het overgrote gedeelte van de casusvoorbeelden herkend werd als behorende bij een specifieke voorkeurscategorie. Van de 106 casusvoorbeelden werd de kwaliteit op een schaal van 1 - 5 gemeten. 77 casusvoorbeelden werden als voldoende beoordeeld. Dat is $51 \%$ van alle casusvoorbeelden. De auteur van dit proefschrift vindt voldoende als judicium voor kwaliteit pas behaald als $60 \%$ van de casusvoorbeelden als zodanig aangemerkt worden. Wel is deze wijze van beoordelen met behulp van een tweetrapsbeoordeling 6 relatief streng, maar wel transparant.

Vervolgens is onderzocht op welke CMI-niveaus de casusvoorbeelden kwalitatief het beste beoordeeld werden. Het blijkt dat voorbeelden van adviseurs werkzaam op niveau A minder goed beoordeeld werd dan van die op niveau B en C, zowel ten aanzien van de categorieën als ten aanzien van de kwaliteit. Ten slotte zijn is ook de relatie van de kwaliteit van arbeidsmarktbegeleiding met de achtergrondvariabelen van de adviseurs onderzocht. Gender en opleiding bleken significant gerelateerd te zijn aan arbeidsmarktbegeleiding. Leeftijd en specifieke werkervaring zijn dat niet. Voor specifieke werkervaring is nader onderzoek nodig om de oorzaak te ontdekken waarom deze in dit onderzoek geen significante samenhang had met arbeidsmarktbegeleiding en wel met het CMI-niveau van de adviseur.

Met betrekking tot de aspecten van de arbeidsmarktbegeleiding is het gebruik van social media en het eigen netwerk het meest gebruikte aspect, maar de wijze van gebruik verschilt van adviseur tot adviseur. Vele loopbaanadviseurs zijn

\footnotetext{
${ }^{6}$ Eerst op categorie en vervolgens op kwaliteit.
} 
van mening dat, als het gaat om arbeidsmarktbegeleiding, de adviseur minder ver moet gaan in de ondersteuning door het eigen netwerk niet in te zetten, maar aan de cliënt duidelijk te maken op welke wijze de cliënt zelf een netwerk kan opbouwen. Gezien dit dilemma is het wel interessant te constateren dat dit aspect het meest beschreven aspect van de arbeidsmarktbegeleiding blijkt te zijn.

\subsubsection{Beperkingen}

Werken met data uit 2012 - 2014: Zoals elk onderzoek kent ook het hierboven beschreven onderzoek beperkingen. In dit hoofdstuk wordt gewerkt met data uit 2012 - 2014. Deze periode is mogelijk voor de huidige arbeidsmarktbegeleiding al enigszins verouderd. Door de snelle veranderingen van de arbeidsmarkt en daardoor ook de snelle veranderingen in de arbeidsmarktbegeleiding, worden sommige aspecten van de begeleiding in de loop van de tijd minder belangrijk, terwijl andere categorieën juist in opkomst zijn. Dit pleit ervoor om op basis van eenzelfde aanpak het hier gepresenteerde onderzoek nog eens te herhalen op basis van nieuwe casusvoorbeelden. Naar de mening van de auteur van dit proefschrift zal een aantal categorieën niet meer verschijnen in een nieuw onderzoek, terwijl het waarschijnlijk zal zijn dat nieuwe categorieën benoemd zullen worden.

Werken met CMI-niveaus: Voor het onderzoek zijn de CMI-niveaus belangrijk. De verschillen tussen de drie niveaus blijken voor het onderzoek naar arbeidsmarktbegeleiding aanzienlijk te zijn. Er is echter ook een beperking: de frequentie van het aantal adviseurs op de niveaus $A$ en $C$ is aanzienlijk lager dan op niveau $B$, waardoor verschillen tussen sommige van de niveaus niet significant zijn terwijl deze mogelijk wel bestaan.

Betrouwbaarheid: De interbeoordelaarsbetrouwbaarheid is laag. Slechts één van de drie groepen geeft een betrouwbaar resultaat, namelijk Cronbach's $\alpha=0,74$. 
Het resultaat van de andere twee groepen was lager dan $\alpha=0,70$. Gezien het betrouwbare resultaat slechts een van de drie groepen van de steekproef betreft, blijkt het onderhavige dossieronderzoek derhalve matig betrouwbaar te zijn. De betrouwbaarheid is daarnaast waarschijnlijk ook laag, omdat het weliswaar dezelfde negen categorieënwaren die beoordeeld moesten worden, maar het waren voor de beoordelaars open vragen. Het waren ook verschillende categorieën, waardoor de beoordelingen specifieker werden. Iedere beoordelaar had mogelijk een eigen idee over iedere categorie, waardoor de betrouwbaarheid mogelijk afneemt. Gezien het feit dat negen categorieën een betrekkelijk laag aantal betreft (hetgeen ook door GT wordt aanbevolen), zal de betrouwbaarheid groter zijn dan als er bijvoorbeeld een keuze zou zijn van 25 categorieën.

Validiteit: De interne validiteit is, evenals bij veel ander praktijkgericht onderzoek, laag. Alle 150 te certificeren loopbaanadviseurs die in de onderzoeksperiode een casusvoorbeeld schreven over een aspect van de arbeidsmarktbegeleiding, schreven de casus op hun eigen wijze, op hun eigen moment en op hun eigen niveau, waardoor er ruis kan zijn ontstaan in het beoordelen van kwaliteit van de arbeidsmarkt-begeleiding.

De externe validiteit van dit onderzoek is daarentegen redelijk hoog. Het dossieronderzoek wordt immers gedaan met casusvoorbeelden van adviseurs die betrekking hebben op authentieke voorbeelden uit hun eigen ervaringen. Als men het vakgebied opvat als beroepsgroep van naar schatting 15000 loopbaanadviseurs, die allen zeggen dat zij als coach of adviseur werken met cliënten en daarmee een inkomen verwerven, dan zou men kunnen zeggen dat de externe validiteit betrekkelijk laag is, omdat het dan maar de vraag is hoe vakbekwaam deze groep van adviseurs zal blijken te zijn. Vat men de beroepsgroep echter op als mensen die 
vakbekwaam zijn om het vak uit te voeren, dan past een hoge validiteit uitstekend bij de conclusies van dit hoofdstuk over de arbeidsmarktbegeleiding.

\subsubsection{Aanbevelingen}

Frequentie: Als beperking is gesteld dat in het onderhavige onderzoek twee van de drie CMI-niveaus te klein blijken te zijn voor representatief onderzoek. Eén niveau blijkt circa twee derde van de casusvoorbeelden te vertegenwoordigen, waardoor er maar weinig voorbeelden voor de andere twee niveaus overblijven. Ook bij een totaal van 150 casusvoorbeelden is het aantal op niveau $A$ en $C$ te beperkt. Derhalve is een groter onderzoek aan te bevelen, met name omdat CMI in de periode 2014 - 2018 voldoende nieuwe te certificeren kandidaten heeft mogen begroeten om een groter onderzoek naar de arbeidsmarktbegeleiding op anonieme basis mogelijk te maken. Interessant is dan ook om een vergelijking te treffen met het huidige onderzoek.

Dynamiek: Dit hoofdstuk begon met de constatering dat de arbeidsmarkt immer in beweging is, waardoor er steeds spanning ontstaat tussen de vraag en het aanbod naar arbeid. Omdat in de keuze van de categorieën de zeer kleine categorieën afvielen, kan dit betekenen dat nieuwe aspecten van de arbeidsmarktbegeleiding onvoldoende in beeld konden worden gebracht. Dit was onder andere het geval bij een voorbeeld van thematisch netwerken en twee voorbeelden van duurzame inzetbaarheid. Dit waren in de periode 2012 - 2014 nauwelijks nog bekende fenomenen, terwijl zeker 'duurzame inzetbaarheid' vier jaar later niet meer weg te denken is uit de begeleidingsaspecten van de loopbaanadviseur. Aangezien de economische ontwikkelingen, en daarmee de arbeidsmarktontwikkeling, steeds sneller gaan, moet de begeleiding in de arbeidsmarkt daar gelijke tred mee houden. 
Dat is voor de loopbaanadviseur lastig, omdat de adviseur geacht wordt deze ontwikkelingen op de voet te volgen om hun cliënten niet tekort te doen.

Als aanbeveling uit de praktijk van de auteur van dit proefschrift, is specialisatie onder de loopbaanadviseurs zeker een goede mogelijkheid. Te denken valt aan voorbeelden als begeleiding van hoogbegaafden, re-integratie $2^{\text {de }}$ spoor en begeleiding van top executives, waardoor cliënten aan specialisten doorverwezen kunnen worden. Een tweede aanbeveling is om door goede netwerken loopbaanadviseurs onderling gebruik te laten maken van elkaars marktexpertise. De sociale netwerken via internet maken goed netwerken aanzienlijk eenvoudiger dan voorheen.

Kwaliteit van de begeleiding: Het centrale thema van dit hoofdstuk is de kwaliteit van de begeleiding van cliënten naar de arbeidsmarkt. De kenvraag omtrent kwaliteit is net niet met een voldoende beantwoord. Om verbetering in de kwaliteit van de arbeidsmarktbegeleiding te brengen, zal vooral veel meer aandacht geschonken moeten worden aan de categorie 'kennis van de ontwikkeling van de arbeidsmarkt'. Voor een belangrijk onderwerp als de kwaliteit van de arbeidsmarktbegeleiding is $51 \%$ toch een zeer mager resultaat. Een belangrijk onderwerp als 'de begeleiding van de cliënt in de arbeidsmarkt' zou glansrijk met een hoog gemiddelde beoordeeld moeten kunnen worden, in plaats van met deze magere beoordeling. Nu het vakgebied zowel op de hogeschool en de universiteit in zwang raakt, zal de 'kennis van de ontwikkeling van de arbeidsmarkt' en de 'begeleiding in de arbeidsmarkt' een meer prominente plaats moeten krijgen. Praktijkervaring door stages zou studenten inzicht moeten geven in de dynamiek van de arbeidsmarkt. Daarnaast kan CMI meewerken door de samenwerking tussen theorie en praktijk te verstevigen, zoals in de loop van 2017 reeds gebeurde door stage- 
plaatsen beschikbaar te stellen en door loopbaanadviseurs aan te moedigen zich academisch te bekwamen.

Kwaliteit van de arbeidsmarktbegeleiding: Het vergroten van de kwaliteit van arbeidsmarktbegeleiding als belangrijk onderdeel van het vakgebied is voor de beroepsgroep in het kader van de ontwikkeling naar een professie van groot belang. Zowel Noloc als CMI zijn daar ten volle van overtuigd. In het huidige jaar 2018 zijn er intensieve gesprekken gaande om door certificering de kwaliteit van de beroepsgroep aanzienlijk aan te scherpen. De beroepsvereniging Noloc heeft circa 3000 leden. Zouden zij allen aan kunnen tonen vakbekwaam te zijn, dan zou in korte tijd bijna een kwart van alle loopbaanadviseurs een certificaat van vakbekwaamheid hebben. Voor de ontwikkeling naar een professie zou dat een grote stap voorwaarts zijn, die de auteur van dit proefschrift van harte kan aanbevelen.

Aspecten van arbeidsmarktbegeleiding: Reeds eerder werd aangegeven dat de arbeidsmarkt steeds in beweging is, waardoor het relatieve belang van de aspecten van de begeleiding steeds zullen wisselen. Een voorbeeld hiervan is het begrip employability. Dat werd in de onderzoeksperiode 2012 - 2014 nog veelvuldig als casusvoorbeeld gebruikt om de kwaliteit van de arbeidsmarktbegeleiding aan te geven. Thans wordt duurzame inzetbaarheid als begrip gebruikt om aan te geven dat het voor cliënten uiterst belangrijk is om in hun werkzame leven steeds bij te blijven door 'life long learning'. Aan te bevelen is om via de CMI-casusvoorbeelden de voorkeurscategorieën te volgen, waardoor de arbeidsmarkt transparant blijft.

Niveauverschillen: Het onderzoek wijst uit dat de casusvoorbeelden die door kandidaten van de bredere niveaus geleverd worden een betere beoordeling kregen dan casusvoorbeelden op het smallere niveau. Dat is niet logisch. Loopbaanadviseurs op het smallere niveau werken van alle te certificeren kandidaten het meest met cliënten. Zij geven cliënten aanwijzingen hoe zij de weg naar de arbeids- 
markt moeten vinden. Zij leren de cliënten netwerken. Door hun één op één contact met de cliënten horen zij veelal in detail wat de cliënten in de markt beleven. Derhalve is het niet alleen onlogisch maar ook vreemd dat de casusvoorbeelden van de adviseurs met een smaller niveau minder beoordeeld worden inzake arbeidsmarktbegeleiding dan hun collegae op het bredere niveau. Wellicht is ook hier de aanbeveling om een grotere steekproef te houden. Een frequentie van een fractie meer dan $20 \%$ is weinig als de totale steekproef slechts 150 casusvoorbeelden groot is. Mocht in een grotere steekproef de uitkomst voor het smallere niveau wederom het minst zijn, dan wordt het tijd om de minimale termijn voor specifieke werkervaring voorafgaande aan de certificering te verhogen.

Achtergrondvariabelen gender, opleiding en specifieke werkervaring: De achtergrondvariabelen gender en opleiding hebben een significante samenhang met arbeidsmarktbegeleiding. Dat verbaast niet. Vrouwelijke adviseurs zijn beter als het op arbeidsmarktbegeleiding aankomt dan hun mannelijke collegae. Adviseurs met een wo-opleiding zijn iets beter dan hun hbo-collegae. Voor beide variabelen is dit niet vreemd, maar in werkelijkheid zouden er hiertussen geen verschillen horen bestaan. In het geval van specifieke werkervaring ligt dat anders. Bij de behandeling van kernvraag 4 is geconstateerd dat er geen samenhang is tussen de specifieke werkervaring van de adviseur en de kwaliteit van diens arbeidsmarktbegeleiding, terwijl er wel een significante samenhang is tussen de CMI-niveaus en de specifieke werkervaring. Dit is vreemd. Derhalve werd reeds de suggestie gedaan voor nader onderzoek. Dat wil de adviseur van dit proefschrift van harte ondersteunen. 



\section{HOOFDSTUK 7}

\section{HET EFFECT VAN DE BEGELEIDING}

\subsection{Inleiding}

In dit hoofdstuk wordt onderzocht welke effecten loopbaanbegeleiding sorteert. Daarbij gaat het om een exploratief veldonderzoek naar de effecten van de begeleiding van cliënten, zoals deze door de drie ondervraagde bronnen (de loopbaanadviseur, diens cliënt en opdrachtgever) worden waargenomen. Hierbij zullen de verschillende doelen van loopbaanbegeleiding onderzocht worden, zoals verbetering van het zelfbeeld en de communicatieve vaardigheden van de cliënt. Daarnaast zal gekeken worden naar het mogelijke effect dat de begeleiding heeft op de tevredenheid van de cliënt met de nieuwe baan of bestemming ${ }^{1}$ op de middellange termijn. In het onderzoek zal ook aandacht worden besteed aan de vraag in hoeverre zowel de cliënten als de opdrachtgevers tevreden zijn over de begeleiding, zowel op korte als op middellange termijn.

Bovendien zal ook onderzocht worden in hoeverre de cliënt volgens de adviseur tevreden is. Dit wordt hieronder geilllustreerd door een voorbeeld uit de praktijk, waarbij in het voorbeeld aangegeven wordt zien hoe een cliënt door een gecertificeerde loopbaanadviseur in het proces begeleid wordt (zie Figuur 7.1). De cliënt heeft, in overleg met de loopbaanadviseur, de ervaring met het loopbaantraject in eigen woorden (dus authentiek) weergegeven. ${ }^{2}$

\footnotetext{
${ }^{1}$ Loopbaanadvisering behoeft niet in alle gevallen te leiden tot een (nieuwe) baan. In sommige gevallen komt de client tot de ontdekking dat hij of zij andere zaken in het leven belangrijker vindt dan een (nieuwe) baan en daarvoor ook wil gaan, zoals bijvoorbeeld gezinsuitbreiding.

${ }^{2}$ De cliënt gaf toestemming on de tekst in dit hoofdstuk op te nemen, maar wil graag evenals de loopbaanadviseur zelf anoniem blijven.
} 
Het effect van de begeleiding:

"Mijn ervaringen met het Loopbaantraject: Toen ik werd aangemeld voor een loopbaantraject omdat mijn teamleider vond dat ik op mijn nieuwe werkplek niet goed functioneerde, was ik in eerste instantie heel sceptisch. Oké, ik zat niet lekker in mijn vel en het werk liep op dat moment niet zoals zou moeten, maar ik had jaren naar behoren en met plezier ditzelfde werk gedaan, dus "het zou wel weer goed komen" als ik eenmaal aan de nieuwe situatie gewend was.

De HR-functionaris meldde dat er tijdens het traject gezocht zou worden naar een functie 'binnen of buiten de organisatie'. Het is dus begrijpelijk dat ik erg achterdochtig en op mijn hoede was tijdens de kennismaking met mijn loopbaancoach. Zij werd tenslotte betaald door de organisatie en zou dus wel handelen in het belang van de werkgever en niet in mijn belang.

Vanaf het eerste moment van kennismaken met mijn loopbaancoach was me duidelijk dat zij er voor mij was en dat het niet alleen om mij als werknemer ging, maar vooral om mij als mens. Direct bij het eerste gesprek heeft ze mij het gevoel van veiligheid en respect gegeven, waardoor het voor mij mogelijk was om volledig open het traject in te gaan. De rode draad in het hele traject, besefte ik gaandeweg, was zelfreflectie en daardoor: bewustwording.

De opdrachten waren duidelijk en soms behoorlijk confronterend. Na iedere bijeenkomst schreef ik een reflectieverslag. Deze verslagen, de oefeningen, opdrachten en gesprekken brachten verheldering en inzicht. Verheldering in het waarom van mijn doen en laten, en inzicht in wat mijn valkuilen zijn, maar ook waar mijn kracht ligt. Door de lijn van verleden, heden en toekomst te gebruiken ontdekte ik dat ik door het verleden was gevormd in wie ik was. Dankzij de huiswerkopdrachten en de gesprekken met mijn coach tijdens het loopbaantraject heb ik kunnen worden wie ik wil zijn.

Het loopbaantraject is een op maat uitgestippeld traject. Hoewel de opdrachten en gesprekken werkgerelateerd waren, heeft het me ook in mijn persoonlijke leven veel opgeleverd. Tijdens de 12 maanden in het traject heb ik geleerd om los te laten wat buiten mijn Cirkel van Invloed ligt en niet van tevoren uit te gaan van aannames. Dankzij de gesprekken en wat ik geleerd heb tijdens het traject ben ik anders in familie- en vriendschapsrelaties gaan staan en dit heeft me veel opgeleverd. Ik ben veranderd, sterker geworden als persoon en dat was zowel op de werkvloer als privé al tijdens het traject merkbaar. Het grootste compliment dat ik kreeg was: 'Je straalt weer!' 
Hoewel ik nu alweer 2 jaar met veel plezier op mijn nieuwe werkplek binnen dezelfde organisatie werkzaam ben maak ik nog regelmatig gebruik van mijn map met alle opdrachten en reflectieverslagen die ik tijdens mijn loopbaantraject heb gemaakt. Ik beschouw het als een soort naslagwerk met handvatten die in nieuwe situaties weer te gebruiken zijn. Mijn loopbaancoach is voor zowel mijn loopbaan-als mijn persoonlijke ontwikkeling heel waardevol geweest." Juni 2016

Figuur 7.1. Casusvoorbeeld van effect van de loopbaanbegeleiding, gegeven door een cliënt (anoniem).

Voor het onderzoek wordt gebruik gemaakt van de respons op drie verschillende enquêtes, ingevuld door de loopbaanadviseurs, hun cliënten en hun opdrachtgevers. Het onderhavige onderzoek is het eerste veldonderzoek naar de effecten van loopbaanbegeleiding door middel van een combinatie van dossieronderzoek en survey-onderzoek gericht op gecertificeerde loopbaanadviseurs.

\subsubsection{Effecten van de begeleiding}

Loopbaanbegeleiding is een vakgebied waar nog weinig onderzoek naar gedaan is (Heppner \& Heppner, 2003). Hier wreekt zich de korte bestaansgeschiedenis van het vakgebied. In dit hoofdstuk zullen de effecten van de begeleiding op drie terreinen onderzocht worden, namelijk: 1) vijf ontwikkelaspecten van de cliënt; 2) de tevredenheid van de cliënt over de nieuwe baan; 3) de tevredenheid van de cliënt en de opdrachtgever met de begeleiding op zowel de korte als op de middellange termijn.

1) Ontwikkelaspecten van de begeleiding van de cliënt: de meest essentiële effecten van de loopbaanbegeleiding, zoals het zelfbeeld van de cliënt, zijn naar weten van de auteur van dit proefschrift nog nauwelijks in het kader van loopbaan-advisering 
onderzocht. De weinige onderzoeken die hier wel naar gedaan zijn, onderzochten slechts enkele aspecten, zoals het verband tussen zelfinzicht en zelfsturend vermogen van cliënten van loopbaanbegeleiding (Verbruggen, 2008). Het onderhavige onderzoek zal gericht zijn op de verbetering van vijf ontwikkelaspecten door de begeleiding van de cliënt. Deze zijn: 1) de verbetering van het zelfbeeld van de cliënt; 2) de verbetering van de relatie van de cliënt met diens werkomgeving; 3) de verbetering van het functioneren van de cliënt; 4) de verbetering van de communicatieve vaardigheden van de cliënt en 5) de verbetering van het zelfsturend vermogen van de cliënt.

2) Baantevredenheid: ten tweede zal het onderzoek gericht zijn op het effect van de begeleiding op de tevredenheid van de cliënt met diens nieuwe baan. Voor de cliënt is een nieuwe baan waar hij of zij tevreden over is, het ultieme doel van de begeleiding.

3) Tevredenheid met de begeleiding: ten derde zal het onderzoek gericht zijn op de mate van tevredenheid over de begeleiding. Daarbij gaat het om de tevredenheid op de korte en middellange termijn van zowel de cliënt als de opdrachtgever. Ondanks de oproep van Heppner \& Heppner (2003), om het tevredenheidseffect naast op de korte termijn ook op langere termijn te onderzoeken, is dit tot op heden, voor zover bekend, nog nimmer gebeurd. Weliswaar hebben enkele onderzoekers de tevredenheid over de loopbaanbegeleiding onderzocht, maar dit betrof meestal slechts de tevredenheid van de cliënt, niet die van de opdrachtgever, noch de inschatting van de tevredenheid van de cliënt door de opdrachtgever en de adviseur. Ook waren deze onderzoeken alleen op de korte termijn gericht (Perdrix et al., 2011). Ook Perdrix et al. onderzochten zelf alleen de korte termijn of hooguit een tweede meting maximaal een jaar later. 


\section{Wetenschap en praktijk}

Bij loopbaanadvisering komt praktijkgestuurd effectenonderzoek slechts spaarzaam voor (Nillesen, 2016). Het feit dat er zo weinig onderzoek is gedaan naar zowel de effecten op de korte termijn als op de middellange termijn wordt, zoals Whiston (2002) constateert, veroorzaakt door de geringe contacten tussen wetenschap en praktijk. Volgens haar zijn data uit de praktijk niet of onvoldoende beschikbaar voor wetenschappelijk onderzoek. Zij constateert zelfs een afname van het onderzoek naar effecten van de interventies van loopbaanbegeleiding. Zij verbindt daar de stelling aan dat zonder hernieuwde interesse in het effectenonderzoek, loopbaanbegeleiding niet meer gezien kan worden als een interventie die wetenschappelijk onderbouwd is. Whiston constateert tevens dat, door gebrek aan onderzoek naar de effecten van de begeleiding, het overzicht ontbreekt inzake loopbaanbegeleidingsmethoden die wel en die niet werken. Watts (2000) en Whiston (2002) pleiten in dit kader voor meer samenwerking tussen de praktijk, de overheid en de wetenschap. Het onderhavige onderzoek is een voorbeeld van samenwerking tussen wetenschap en praktijk.

Praktijkgestuurd effectenonderzoek komt op andere gebieden in het sociale domein veel meer voor. Interessante voorbeelden van praktijk gestuurd effectenonderzoek zijn onder meer het effectenonderzoek van Van Yperen en Veerman (2008) bij de jeugdzorg en het effectenonderzoek van Verbruggen (2008) inzake zelfsturing en het effectenonderzoek van Nelissen (2016). Deze laatste ontwikkelde voor Van Ede \& Partners een instrument, waarmee de effectiviteit van loopbaanbegeleiding gemeten kan worden. Het onderzoek naar de effecten van loopbaanadvisering staat dus wel op de agenda. Ook is er steeds meer aandacht voor de mate van samenwerking tussen wetenschap en de praktijk. Zo heeft OECD reeds in 2004 een publicatie uitgebracht over "Bridging the Gap" tussen wetenschap en praktijk. 
Ook IAEVG (International Association for Education and Vocational Guidance) heeft in 2005 te Parijs een conferentie over de effecten van de begeleiding gehouden en meer recent besteedde NICE (Network for Innovation in Career Guidance and Counselling in Europe) in 2017 tijdens een conferentie in Padua aandacht aan deze onderwerpen. Het huidige onderzoek voorziet in een belangrijke behoefte door een bijdrage te leveren aan het vergroten van het inzicht in de effecten van loopbaanbegeleiding voor de cliënt op korte en middellange termijn door middel van veldonderzoek met cliënten in een authentieke begeleidingscontext.

\subsubsection{Kernoragen}

Om te onderzoeken of er een effect is met betrekking tot de begeleiding van de cliënt, werd een aantal verschillende variabelen in relatie tot het effect onderzocht. Het effect van de begeleiding in samenhang met variabelen zoals de vijf ontwikkelaspecten, de baantevredenheid, het CMI-niveau en de achtergrondvariabelen van de loopbaanadviseur zullen onderzocht worden naar aanleiding van de volgende zeven kernvragen.

Kernvraag 1: In welke mate heeft loopbaanbegeleiding invloed op: a) de vijf ontwikkelaspecten, te weten: het zelfbeeld, de relatie met de werkomgeving, het functioneren, de communicatieve vaardigheden en de zelfsturing van de cliënt; b) de baantevredenheid van de cliënt; en c) de tevredenheid met de begeleiding van de cliënt en de tevredenheid met de begeleiding van de opdrachtgever op de korte en middellange termijn?

Kernvraag 2: Welke samenhang is er tussen de vijf ontwikkelaspecten onderling, vanuit het gezichtspunt van: a) de adviseur; b) de cliënt zelf en c) de opdrachtgever? 
Kernvraag 3: Is er een relatie tussen de tevredenheid van zowel de cliënt als de opdrachtgever met de begeleiding op de korte termijn en die op de middellange termijn en hoe sterk is die relatie?

Kernvraag 4: Is er een relatie tussen de tevredenheid van de cliënt met de begeleiding en: a) de vijf ontwikkelaspecten van de cliënt en b) de baantevredenheid van de cliënt?

Kernvraag 5: Is er een relatie tussen de vijf ontwikkelaspecten van de cliënt en diens baantevredenheid?

Kernvraag 6: Is er een relatie tussen het CMI-niveau van de adviseur en: a) de vijf ontwikkelaspecten van de cliënt; b) de baantevredenheid van de cliënt en c) de tevredenheid van de cliënt met de begeleiding op de korte en middellange termijn?

Kernvraag 7: Is er een relatie tussen de achtergrondvariabelen (gender, leeftijd, opleiding en specifieke werkervaring) van de adviseur en de vijf ontwikkelaspecten van de cliënt?

\subsubsection{Onderzoeksmethodieken}

Er worden in dit onderzoek twee onderzoeksmethoden gebruikt om de effecten van loopbaanbegeleiding op korte en middellange termijn te onderzoeken: 1) De Net Promotor Score (Reichheld, 2002): deze maatstaf wordt hier gebruikt om het effect van de begeleiding op korte en op middellange termijn te meten in termen van de tevredenheid van de cliënten zelf en in de perceptie hiervan bij de opdrachtgevers. 
2) De Theory of Change: deze onderzoeksmethode van Weiss $(1972 ; 2000)$ wordt ingezet om de tevredenheidseffecten van de begeleiding op de korte en middellange termijn te kunnen onderzoeken.

De Net Promotor Score (NPS) is door Reichheld (2003) ontworpen als (marketing-) indicator voor de mate waarin cliënten loyaal zijn aan hun aanbieder. Dat wil voor loopbaanadvisering zeggen: tevreden zijn over de loopbaanadviesdiensten. Op basis van deze indicator wordt de mate van tevredenheid op de korte en middellange termijn gemeten. De standaard NPS-indicator bestaat uit één vraag ‘Hoe waarschijnlijk is het dat $\mathrm{u}$ deze aanbieder zou aanbevelen bij een vriend of collega?' Vertaald naar het onderhavige onderzoek luidt de vraag: 'Hoe tevreden bent $u$ over de adviseur als aanbieder van loopbaanadviesdiensten en zou $u$ deze adviseur aanbevelen bij een vriend of collega?' De respondent (in dit geval zowel de cliënt als de opdrachtgever) wordt gevraagd de vraag te beantwoorden op een schaal van $0-10$. Scores van 0-6 worden geoormerkt als zijnde antwoorden van cliënten die geen aanbevelingen zouden doen aan een vriend of collega. Scores van 7 en 8 worden geoormerkt als zijnde uitspraken van cliënten of opdrachtgevers die geen uitgesproken mening hebben over de gestelde vraag en scores van 9 en 10 worden geoormerkt als zijnde uitspraken van cliënten of opdrachtgevers die een aanbeveling zouden willen doen aan een vriend of collega.

De NPS wordt berekend door het percentage negatieve scores (0-6) af te trekken van het percentage positieve scores (9 en 10). Hoe hoger de score, hoe 'loyaler', in de termen van Reichheld, de klant is ten opzichte van de aanbieder. In de termen van dit onderzoek: hoe hoger de score, des te tevredener de cliënt en de opdrachtgever zijn. Een positieve score (een cijfer tussen 0-49), geeft aan dat de cliënt 
(en de opdrachtgever) tevreden zijn met de begeleiding door de loopbaanadviseur. Alle scores hoger dan 49 geeft Reichheld het judicium 'uitmuntend'.

Naast het cijfermatige antwoord vraagt Reichheld ook om een tekstuele toelichting (motivatie) van de cijfermatige beoordeling, dus over de vraag waarom de cliënt en de opdrachtgever de aanbieder zouden aanraden bij een vriend of collega. Dit verruimt volgens Reichheld het inzicht in de factoren die de tevredenheid beïnvloeden. In Bijlage 7A worden voorbeelden getoond van de tekstuele toelichtingen op hoog gescoorde tevredenheidsverklaringen van het onderhavige onderzoek.

De Theory of Change: In zijn bijdrage aan de bundel 'Weten wat werkt' evalueert Snel (2013) de 'praktijktheorie's van Weiss (1972). Snel constateert, in navolging van Weiss, dat de Theory of Change ('veranderingstheorie') kan worden ingezet als alternatief voor experimenteel evaluatieonderzoek. Bij experimenteel evaluatieonderzoek wordt normaliter bewijs gezocht voor het feit dat een interventie werkt door gebruik te maken van een effectgroep (met interventie) en een controlegroep (zonder interventie).

Weiss geeft aan dat het volgens haar ook mogelijk is inzicht te krijgen in de effecten van een interventie zonder een controle-groep. Een controlegroep wordt gebruikt om effecten van interventies te meten, door een effectgroep met interventie te vergelijken met de controlegroep zonder interventie. De controlegroep moet dan totaal gelijk zijn aan de effectgroep, afgezien van de interventie. Aangezien er in veel veldonderzoek naast de interventie nog andere verschillen kunnen zijn tussen de groepen, is het meten van effecten met behulp van een controlegroep vaak moeilijk.

\footnotetext{
${ }^{3}$ Met 'praktijktheorie' bedoelt Weiss niet zozeer wetenschappelijke theorieën, maar het geheel van assumpties van professionals over de werking van interventies. Het gaat om een handelingstheorie zoals die in de praktijk door professionals wordt gehanteerd. Omdat er in de Theory of Change een verwachting aan ten grondslag ligt wordt door Weiss over een 'theorie' gesproken.
} 
Weiss zoekt daartoe naar de factoren die ervoor kunnen zorgen dat een interventie in de ene situatie wel een bepaald effect sorteert en in een andere situatie niet.

De voorwaarden voor het slagen van onderzoek op basis van de Theory of Change zijn volgens Weiss dat: 1) bepaalde effecten vooraf verwacht worden, voor zowel de korte als de langere termijn; 2) er achteraf een gedegen effectmeting plaatsvindt, waaruit blijkt of de voorspelde effecten ook daadwerkelijk optreden; 3) er voldoende waarnemingen zijn en 4) er voldoende tijd wordt uitgetrokken tussen de waarnemingen op korte, middellange en lange termijn. Doordat een controlegroep in het onderhavige onderzoek ontbreekt, is de 'veranderingstheorie' voor het onderhavige onderzoek bruikbaar, gezien het feit dat aan alle vier de door Weiss genoemde voorwaarden werd voldaan.

De term 'veranderingstheorie' geeft tevens aan dat de interventies op korte, middellange en lange termijn verschillende uitkomsten kunnen hebben. Zo kan de interventie op korte termijn een zeer verschillend effect hebben vergeleken met de effecten op middellange en lange termijn. Een voorbeeld van een succesvolle verandering op het terrein van de loopbaanadvisering is: een netwerkgesprek als interventie om een baan te vinden die bij de cliënt past. De korte termijn uitkomst is dan dat deze baan gevonden wordt. De middellange-termijnuitkomst is dat de cliënt ook succesvol is in de nieuwe baan en de lange-termijnuitkomst is dat de baan duurzaam is. Met andere woorden: het gaat om verschillende uitkomsten, die in de tijd veroorzaakt worden door één en dezelfde interventie, in de verwachting dat het een baan betreft die bij de cliënt past.

Oliver (1979) geeft aan dat het 'follow-up' onderzoek naar de vraag of een interventie een bepaald effect heeft gesorteerd niet te lang na de interventie mag plaatsvinden. Dit omdat de invloed van andere factoren dan te groot zou worden. In het onderhavige onderzoek is er geen lange-termijnonderzoek gedaan, maar wel 
een korte-termijn- en een middellange-termijnonderzoek. Overeenkomstig het advies van Oliver is gekozen voor een onderzoek in de periode 2012 - 2014, gevolgd door een follow up in 2016 - 2017 om de respectievelijke effecten op de korte en middellange termijn te onderzoeken.

Weiss (1972) geeft aan dat de veranderingstheorie kan worden weergegeven door de veronderstelde relatie tussen beschikbare hulpbronnen (de adviseur), interventies (het programma) en uitkomsten op korte en langere termijn aan te geven als een 'flow'. Weiss geeft het volgende voorbeeld: hulpbron (adviseur) > interventie (programma) > verandering van attitude (korte termijn) > verkrijgen van een baan (middellange termijn) > het hebben van een duurzame baan (lange termijn). In het onderhavige onderzoek naar de korte- en middellange-termijneffecten van de loopbaanbegeleiding ziet de flow er als volgt uit (zie Figuur 7.2).

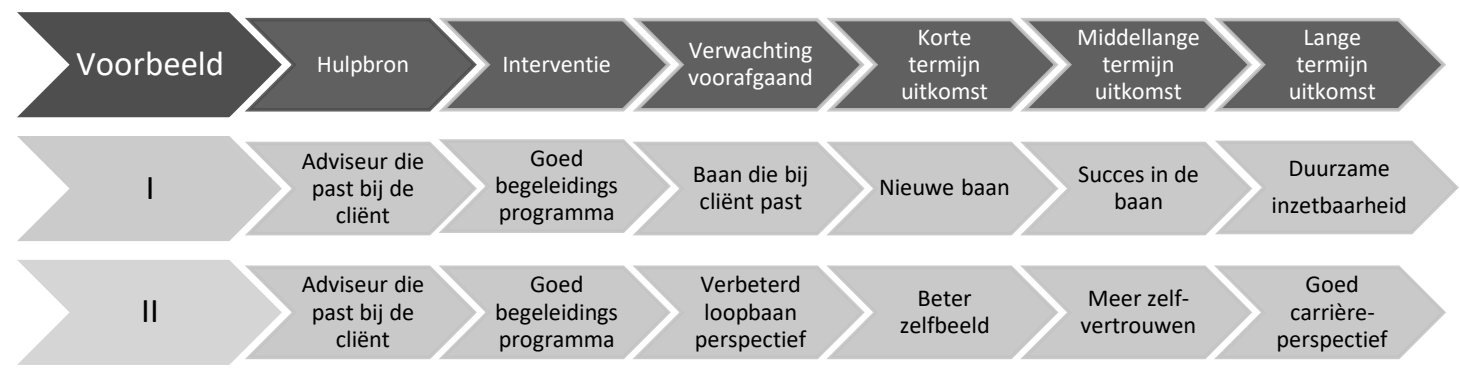

Figuur 7.2. Veronderstelde flow: relatie tussen beschikbare hulpbronnen, interventies en uitkomsten, in navolging van Weiss (1972), tweemaal toegepast op veronderstelde effecten van loopbaanbegeleiding.

In Tabel 7.1 wordt de effectenladder getoond, zoals deze is opgesteld door Van Yperen en Veerman (2008) op basis van de veranderingstheorie van Weiss. In de Theory of Change geeft 'verandering' beweging aan; bijvoorbeeld een beweging 
als gevolg van een interventie. Dit wordt door Van Yperen en Veerman (2008), in navolging van Weiss, de effectenladder genoemd. Van Yperen en Veerman omschrijven de kwalificaties van de interventies oplopend van potentieel, veelbelovend, doeltreffend tot werkzaam en geven deze in hun effectenladder weer.

\subsubsection{Opzet van het hoofdstuk}

Na de bespreking van de methode in paragraaf 7.2, waarbij het design, het pilotonderzoek, de steekproef en de meetinstrumenten aan de orde komen, zullen in paragraaf 7.3 de resultaten van het onderzoek besproken worden. Paragraaf 7.4 beschrijft door een discussie de belangrijkste conclusies met betrekking tot de effecten van de begeleiding.

\subsection{Methode}

\subsubsection{Design}

Het onderhavige veldonderzoek bestaat uit een combinatie van dossieronderzoek en survey-onderzoek. De data werden op twee momenten verzameld: 1) in de periode 2012 - 2014 (T1) werden data door CMI verzameld (dossieronderzoek): loopbaanadviseurs stuurden per email vijf cliënten en/of opdrachtgevers een verzoek om een tevredenheidsverklaring in te vullen ${ }^{4}$. Voor CMIniveau A werd gevraagd vijf tevredenheidsverklaringen van cliënten te tonen; voor CMI-niveau B: drie verklaringen van cliënten en twee opdrachtgeversverklaringen of andersom; en voor CMI-niveau C: vijf verklaringen van opdrachtgevers. Deze verklaringen werden per email via de adviseur aan CMI

\footnotetext{
${ }^{4}$ De opdrachtgever heeft alleen zicht op de werkomgeving, het functioneren en de communicatieve vaardigheden van de cliënt, maar geen zicht op diens zelfbeeld en het zelfsturend vermogen. Deze laatste twee ontwikkelaspecten zijn daarom niet opgenomen in de enquête die aan de opdrachtgevers werd voorgelegd.
} 
verstrekt dan wel direct aan CMI gestuurd. In deze periode werden door CMI circa 300 loopbaanadviseurs gecertificeerd, dan wel gere-certificeerd.

2) In de periode 2016 - 2017 (T2) werd ten behoeve van dit onderzoek een enquête voorgelegd aan loopbaanadviseurs, cliënten en opdrachtgevers (surveyonderzoek). De adviseurs werd gevraagd zelf een enquête in te vullen en vijf van hun cliënten en/of opdrachtgevers op te geven aan wie ook een enquête mocht worden gestuurd.

De data werden verzameld via een database (Form desk) en digitaal verwerkt en geregistreerd op basis van Excel, waardoor verdere statistische verwerking door SPSS mogelijk werd. Zowel voor de adviseurs als voor hun cliënten en opdrachtgevers werden enquêteformulieren met een beperkt aantal (6-8) vragen samengesteld. Het aantal enquêtevragen werd bewust beperkt gehouden om een zo hoog mogelijke respons te krijgen, om zo de representativiteit van de onderzoeksresultaten te vergroten.

De respons op de enquêtes op T2 van de drie bronnen vormt naast de tevredenheidsverklaringen op T1 de basis voor het verdere onderzoek. Door de twee verschillende meetmomenten werd het mogelijk om metingen te doen op de korte en op de middellange termijn met gemiddeld drieënhalf jaar daartussen. Daardoor kunnen de antwoorden van deze metingen onderling vergeleken worden.

Pilotonderzoek: Voorafgaande aan de verspreiding van de enquêtes werd eerst een pilotonderzoek verricht om de kwaliteit van de bewust beperkt gehouden vragenlijst en de begeleidende mailbrieven te toetsen. Zestien experts (mentoren van CMI) deden mee aan de pilotstudie. Tien van hen gaven suggesties ter verbetering, die deels in de enquêteformulieren en de mailbrieven verwerkt werden. 
Tabel 7.1

De effectenladder: niveaus van bewijskracht in praktijk gestuurd effectonderzoek

(Van Yperen E Veerman, 2008).

\begin{tabular}{|c|c|c|c|}
\hline Niveau & Bewijskracht & Omschrijving & Soorten onderzoek \\
\hline 4. & $\begin{array}{c}\text { Zeer grote } \\
\text { bewijskracht }\end{array}$ & $\begin{array}{l}\text { Als } 1 \text { tot en met } 3 \text {, maar nu is } \\
\text { er evidentie dat positieve } \\
\text { uitkomsten veroorzaakt } \\
\text { worden door de interventie. }\end{array}$ & \multirow{2}{*}{$\begin{array}{l}\begin{array}{l}\text { Experimenteel veldonderzoek } \\
\text { (enquête) }\end{array} \\
\text { Herhaalde case studies } \\
\text { Quasi-experimenteel } \\
\text { onderzoek } \\
\text { Verandering theoretisch } \\
\text { onderzoek } \\
\text { Norm gerelateerd onderzoek } \\
\text { (bijv. ISO) } \\
\text { - - - - - - - - - - - - - - - - - - - - - - } \\
\text { Veranderingsonderzoek } \\
\text { Doelrealisatie onderzoek } \\
\text { Cliënttevredenheidsonderzoek }\end{array}$} \\
\hline 3. & $\begin{array}{c}\text { Grote } \\
\text { bewijskracht }\end{array}$ & $\begin{array}{l}\text { Als } 1 \text { en } 2 \text {, maar nu kan } \\
\text { empirisch worden } \\
\text { aangetoond dat de gestelde } \\
\text { doelen zijn bereikt, } \\
\text { problemen afgenomen en } \\
\text { competenties toegenomen, en } \\
\text { cliënten tevreden zijn. }\end{array}$ & \\
\hline 2. & $\begin{array}{c}\text { Weinig } \\
\text { bewijskracht }\end{array}$ & $\begin{array}{l}\text { Als 1, maar is er ook een } \\
\text { interventietheorie over welke } \\
\text { factoren met de problemen } \\
\text { van de doelgroep } \\
\text { samenhangen en waarom de } \\
\text { interventie de beoogde } \\
\text { uitkomsten bereikt. }\end{array}$ & $\begin{array}{l}\text { Meta-analyse } \\
\text { Literatuurstudie } \\
\text { Kennis ontlokkend } \\
\text { onderzoek }\end{array}$ \\
\hline 1. & $\begin{array}{c}\text { Geringe } \\
\text { bewijskracht }\end{array}$ & $\begin{array}{l}\text { De kernelementen van een } \\
\text { interventie (doelgroep, } \\
\text { interventie, uitkomsten) en } \\
\text { personele, organisatorische } \\
\text { en materiële context en } \\
\text { randvoorwaarden zijn } \\
\text { duidelijk en begrijpelijk } \\
\text { beschreven. }\end{array}$ & $\begin{array}{l}\text { Descriptief onderzoek } \\
\text { Observationeel onderzoek } \\
\text { Documentanalyse } \\
\text { Interviews }\end{array}$ \\
\hline
\end{tabular}




\subsubsection{Steekproef}

Op T1 werden ten behoeve van het aanleggen van dossiers in totaal 120 tevredenheidsverklaringen van cliënten en 72 tevredenheidsverklaringen van opdrachtgevers ontvangen over de begeleiding. Deze werden door de te certificeren adviseurs als verklaring van de cliënt en van de opdrachtgever toegevoegd aan het dossier. Om de verzamelde korte termijn data van T1 te kunnen vergelijken met de middellange termijn, werd in 2016 - 2017 (T2) een enquête verstuurd naar 300 Register Loopbaanadviseurs (RL ${ }^{5}$ ) die op 30 juni 2014 werkzaam waren. Helaas moesten 30 kandidaten afhaken omdat hun werkgever geen toestemming gaf om mee te doen. Derhalve ontvingen er uiteindelijk 270 adviseurs een enquêteformulier op T2, waarvan in totaal 161 (59,6\%) adviseurs de enquêtevragen beantwoordden.

Van 96 van deze adviseurs werden tevens ingevulde enquêteformulieren van hun cliënten $(N=129)^{6}$; en/of hun opdrachtgevers $(N=96)$ retour ontvangen. Zodoende konden 225 enquêteformulieren van 96 adviseurs gekoppeld worden aan 129 formulieren van cliënten en 96 enquêteformulieren van opdrachtgevers. Van deze 225 enquêteformulieren waren 23 (10,3\%) formulieren van adviseurs op CMIniveau A; 121 (53,7\%) van adviseurs op CMI-niveau B en 81 (36\%) van adviseurs op CMI-niveau C. Daarnaast waren er nog 65 adviseurs die een enquêteformulier invulden, maar waarvan geen van hun cliënten of opdrachtgevers een enquêteformulier had ingevuld, waardoor deze niet gekoppeld konden worden. In totaal werden op T2 derhalve 515 formulieren retour ontvangen en verwerkt. In Tabel 7.2 wordt de samenstelling van de respons getoond.

\footnotetext{
${ }^{5}$ RL: Register Loopbaanprofessionals zijn loopbaanadviseurs die door CMI-certificering hun vakbekwaamheid hebben aangetoond. Na een geslaagde certificering mogen zij de titel RL voeren.

${ }^{6}$ Het was mogelijk om per adviseur meerdere cliënten en opdrachtgevers mee te laten doen aan de enquête.
} 
Tabel 7.2.

Respons door adviseurs, cliënten en opdrachtgevers op T1 en T2.

\begin{tabular}{lcccc}
\hline & Adviseurs & Cliënten & $\begin{array}{c}\text { Opdracht- } \\
\text { gevers }\end{array}$ & Totaal \\
\hline Tevredenheidsverklaringen (T1) & n.v.t. & 120 & 72 & 192 \\
Potentiële deelnemers (T2) & 270 & 810 & 540 & 1620 \\
Uiteindelijke deelnemers (T2) & 161 & 129 & 96 & 386 \\
$\begin{array}{l}\text { Retour ontvangen } \\
\text { enquêteformulieren (T2) }\end{array}$ & 290 & 129 & 96 & 515 \\
$\begin{array}{l}\text { Gekoppelde enquêteformulieren } \\
\text { (T2) }\end{array}$ & 225 & 129 & 96 & 450 \\
$\begin{array}{l}\text { Niet-gekoppelde } \\
\text { enquêteformulieren (T2) }\end{array}$ & 65 & n.v.t. & n.v.t. & n.v.t. \\
\hline
\end{tabular}

Adviseurs: De gemiddelde leeftijd van de 161 loopbaanadviseurs die aan het onderzoek deelnamen was 53 jaar $(S D=6,3) .72(56 \%)$ vrouwelijke adviseurs en 56 (44\%) mannelijke adviseurs kon aan een cliënt en/of opdrachtgever gekoppeld worden. Doordat per adviseur door meerdere cliënten en opdrachtgevers enquêteformulieren konden worden ingeleverd werden 169 van de 225 formulieren specifiek gekoppeld aan vrouwelijke adviseurs (75\%).

Alle loopbaanadviseurs hadden een hbo- $(65 \%)$ of wo- $(35 \%)$ opleiding gevolgd, maar niet noodzakelijkerwijs een hbo- of wo-opleiding in loopbaanadvisering. De gemiddelde algemene werkervaring was 25 jaar met een $S D$ van 7,9 jaar. De gemiddelde specifieke werkervaring was 11 jaar met een $S D$ van 4,8 jaar. 
Om privacy redenen werd niet gevraagd naar de functie in de organisatie van de adviseurs.

Cliënten: De gemiddelde leeftijd van de 120 cliënten die op zowel T1 als T2 aan het onderzoek deelnamen, was op T2: $M=47$ jaar $(S D=6,3)$. Ook bij de cliënten waren vrouwen in de meerderheid, te weten: 82 van de 128; dat is $64 \%$. Het merendeel van de cliënten had een hbo- of wo-opleiding.

Opdrachtgevers: Bij de opdrachtgevers waren mannelijke respondenten nipt in de meerderheid, te weten: 51 van de 96 opdrachtgevers (52,6\%). Om privacy redenen werd niet gevraagd naar de leeftijd, de opleiding en de functie in de organisatie van de opdrachtgevers.

Tabel 7.3 geeft een overzicht van de achtergrondvariabelen van de adviseurs, cliënten en de opdrachtgevers die deelnamen aan het onderzoek.

\subsubsection{Meetinstrumenten}

1) De vijf ontwikkelaspecten van de cliënt werden gemeten door middel van de enquête op T2. Daarbij werden de volgende ontwikkelaspecten van de begeleiding aan de respondenten voorgelegd: de verbetering van het zelfbeeld, van de relatie met de werkomgeving, van het functioneren, van de communicatieve vaardigheden en van het zelfsturend vermogen van de cliënt. De antwoorden werden telkens gescoord op basis van een Likertschaal, waarbij $1=$ in zeer geringe mate en $5=$ in zeer hoge mate. De vijf ontwikkelaspecten werden voorgelegd aan de adviseur, de cliënt en de opdrachtgever. De adviseur: De verbetering van loopbaanontwikkeling van de cliënt in de ogen van de adviseur (m.a.w. de perceptie) werd in de enquête met een vijftal vragen gemeten, direct gerelateerd aan de vijf genoemde ontwikkelaspecten. Een voorbeeldvraag is: "In welke mate heeft de begeleiding in uw ogen effect gehad op het zelfsturend vermogen van uw cliënt?" 
Tabel 7.3

Achtergrondvariabelen adviseurs, cliënten en opdrachtgevers.

\begin{tabular}{|c|c|c|c|c|c|c|}
\hline \multirow{2}{*}{$\begin{array}{l}\text { Achtergrond- } \\
\text { Variabele }\end{array}$} & \multicolumn{2}{|l|}{$\begin{array}{l}\text { Adviseurs } \\
(N=161)\end{array}$} & \multicolumn{2}{|l|}{$\begin{array}{l}\text { Cliënten } \\
(N=129)\end{array}$} & \multicolumn{2}{|c|}{$\begin{array}{c}\text { Opdrachtgevers } \\
\qquad(N=96)\end{array}$} \\
\hline & Man: & 56 & Man: & 47 & Man: & 51 \\
\hline & Vrouw: & 169 & Vrouw: & 82 & Vrouw: & 45 \\
\hline Leeftijd & \multicolumn{2}{|l|}{$\begin{array}{c}53 \text { jaar } \\
(S D=6,3)\end{array}$} & \multicolumn{2}{|l|}{$\begin{array}{c}47 \text { jaar } \\
(S D=6,3)\end{array}$} & \multicolumn{2}{|l|}{ n.v.t. } \\
\hline \multirow[t]{4}{*}{ Opleiding } & havo + ass: & 22 & havo: & 3 & n.v.t. & \\
\hline & mbo: & 0 & mbo: & 16 & & \\
\hline & hbo: & 124 & hbo: & 60 & & \\
\hline & wo: & 79 & wo: & 50 & & \\
\hline $\begin{array}{l}\text { Specifieke } \\
\text { werkervaring }\end{array}$ & \multicolumn{2}{|l|}{$\begin{array}{c}11 \text { jaar } \\
(S D=4,8)\end{array}$} & \multicolumn{2}{|l|}{ n.v.t. } & \multicolumn{2}{|l|}{ n.v.t } \\
\hline Richting/ & Gedrag: & 142 & Administratie: & 10 & n.v.t. & \\
\hline Opleiding/ & P\&O + HRM: & 19 & Bedrijfskunde: & 5 & & \\
\hline \multirow[t]{9}{*}{ Bedrijfstak } & Taal/cultuur: & 11 & Economie: & 13 & & \\
\hline & Gezondheid: & 11 & Gezondheid: & 19 & & \\
\hline & Rechten: & 10 & Gedrag: & 19 & & \\
\hline & Techniek: & 6 & Onderwijs: & 10 & & \\
\hline & Economie: & 5 & Rechten: & 6 & & \\
\hline & Onderwijs: & 5 & Techniek: & 12 & & \\
\hline & Communicatie: & 1 & Taal/cultuur: & 8 & & \\
\hline & Overig: & 15 & Communicatie & 7 & & \\
\hline & & & Overig: & 19 & & \\
\hline (Nieuwe) & DGA: & 15 & Management: & 15 & Management: & 44 \\
\hline \multirow[t]{8}{*}{ functie (in) } & zzp: & 138 & P\&O: & 14 & P\&O: & 38 \\
\hline & Loondienst: & 72 & Financiën/Ad: & 8 & Marketing/ & 2 \\
\hline & Loopbaan adv.: & 37 & Marketing/ & & Sales: & \\
\hline & Overheid: & 23 & Sales: & 5 & Productie: & 4 \\
\hline & Semi overheid: & 6 & Productie: & 5 & Research: & 4 \\
\hline & Bank + verzeker: & 4 & Research: & 5 & Financiën: & 2 \\
\hline & Arbo: & 2 & ICT: & 2 & Inkoop: & 2 \\
\hline & Overig: & 3 & Overig: & 75 & Overig: & 2 \\
\hline Totaal: & & 300 & & 129 & & 96 \\
\hline
\end{tabular}


De cliënt: In de enquête aan de cliënten werden ook alle vijf ontwikkelaspecten gemeten. Daarbij werd bijvoorbeeld de volgende vraag gesteld: “In welke mate heeft de begeleiding effect gehad op hoe u naar uzelf kijkt in relatie tot werk (zelfbeeld)?"

De opdrachtgever: De verbetering van de loopbaanontwikkeling van de cliënt in de ogen van de opdrachtgever (m.a.w. perceptie) werd in de enquête gemeten aan de hand van drie van de vijf vragen van de genoemde ontwikkelaspecten: 1) de verbetering van de relatie met de werkomgeving, 2) van het functioneren en 3) van de communicatieve vaardigheden van de cliënt in de ogen van de opdrachtgever. Een voorbeeldvraag is: "In welke mate heeft de begeleiding in uw ogen effect gehad op het functioneren van de medewerker in zijn/haar huidige werkkring?" (Noot: de opdrachtgever heeft over het algemeen geen goed zicht op het zelfbeeld en de zelfsturing van de cliënt. Daarom werden er hierover in de enquête aan de opdrachtgever geen vragen gesteld.)

2) De baantevredenheid: De tevredenheid met de baan werd uitsluitend aan de cliënt gevraagd als onderdeel van de enquête op T2. Baantevredenheid werd gemeten met één vraag, namelijk: “In welke mate heeft de begeleiding effect gehad op uw tevredenheid over uw baan?" Ook voor deze vraag werd een Likertschaal gebruikt, waarbij $1=$ in zeer geringe mate en $5=$ in zeer hoge mate.

3) De teoredenheid met de begeleiding (zelfperceptie): In het onderhavige onderzoek werd zowel de tevredenheid van de cliënt als die van de opdrachtgever met de begeleiding gemeten, zowel in periode T1 als in periode T2. Anders dan in de andere enquêtevragen, werd hiervoor een 10-puntschaal gebruikt, waarbij $1=$ in zeer geringe mate en $10=$ in zeer hoge mate. Voor deze 10-puntschaal werd gekozen, omdat op T1 voor de z.g. tevredenheidsverklaringen van de cliënten en opdracht- 
gevers eenzelfde 10-puntschaal was gebruikt. Op deze wijze konden de tevredenheid van een cliënt op de korte termijn en middellange termijn beter vergeleken worden.

De adviseur: de tevredenheid van de cliënt met de begeleiding in de ogen van de adviseur (m.a.w., perceptie) werd alleen gemeten op T2, met de vraag "In welke mate is de cliënt in uw ogen tevreden over uw begeleiding inzake vragen omtrent de ontwikkeling van zijn/haar loopbaan?"

De cliënt: De tevredenheid van de cliënt met de begeleiding werd zowel op T1 als T2 gemeten met één vraag, namelijk: “In welke mate bent u tevreden over uw begeleiding inzake vragen omtrent uw loopbaan?"

De opdrachtgever: De tevredenheid van de opdrachtgever met de begeleiding door de adviseur werd op zowel meetmoment T1 als T2 gemeten met de vraag: "In welke mate bent $\mathrm{u}$ zelf tevreden over de loopbaanadviseur die $\mathrm{u}$ heeft aangezocht voor de begeleiding van deze cliënt?" Daarnaast werd de opdrachtgever op T2 ook gevraagd naar zijn of haar perceptie van de tevredenheid van de cliënt met de begeleiding: "In welke mate is in uw ogen de cliënt/ medewerker tevreden over zijn/haar begeleiding inzake vragen omtrent zijn/haar loopbaan?" Op deze wijze konden de korte-termijnresultaten en de middellange-termijnresultaten van de opdrachtgever met elkaar vergeleken worden. In Figuur 7.3 wordt een overzicht gegeven van alle gemeten variabelen op T1 en T2, per bron (adviseur, cliënt, opdrachtgever). 


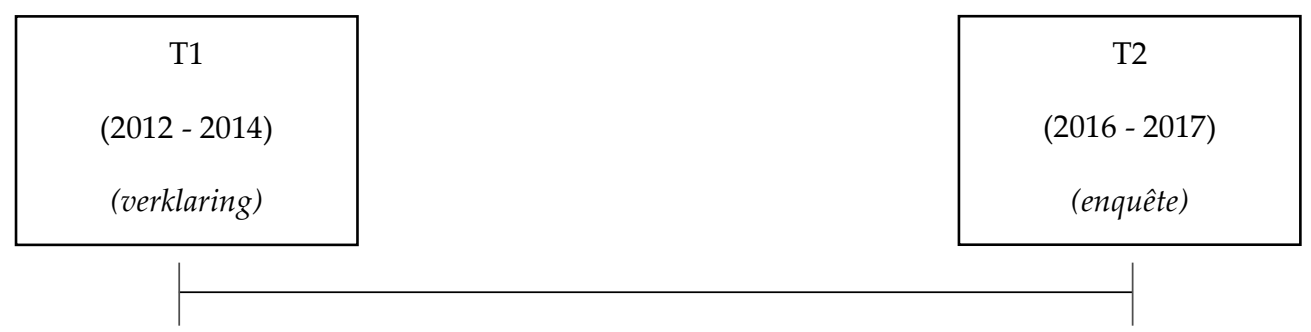

\begin{tabular}{|c|c|}
\hline $\begin{array}{c}\text { Adviseur: } \\
-\end{array}$ & \begin{tabular}{l}
\multicolumn{1}{c}{ Adviseur: } \\
- $\quad$ Perceptie van tevredenheid van \\
cliënt met begeleiding \\
- Ontwikkelaspecten: \\
- zelfbeeld \\
- relatie werkomgeving \\
- functioneren \\
- communicatieve vaardigheden \\
- zelfsturend vermogen
\end{tabular} \\
\hline $\begin{array}{c}\text { Cliënt: } \\
\text { - Tevredenheid met begeleiding } \\
\text { - }\end{array}$ & $\begin{array}{l}\text { Cliënt: } \\
\text { - } \quad \text { Tevredenheid met begeleiding } \\
\text { - Ontwikkelaspecten: } \\
\text { - zelfbeeld } \\
\text { - relatie werkomgeving } \\
\text { - functioneren } \\
\text { - communicatieve vaardigheden } \\
\text { - zelfsturend vermogen } \\
\text { - Baantevredenheid }\end{array}$ \\
\hline $\begin{array}{c}\text { Opdrachtgever: } \\
\text { - Tevredenheid met begeleiding } \\
\text { - } \\
\text { - }\end{array}$ & $\begin{array}{l}\text { Opdrachtgever: } \\
\text { - } \quad \text { Tevredenheid met begeleiding } \\
\text { - } \quad \text { Perceptie van tevredenheid van } \\
\text { cliënt met begeleiding } \\
\text { - Ontwikkelaspecten: } \\
\text { - relatie werkomgeving } \\
\text { - functioneren } \\
\text { - communicatieve vaardigheden }\end{array}$ \\
\hline
\end{tabular}

Figuur 7.3. Tijdbalk: overzicht van alle gemeten variabelen op T1 en T2, per bron (adviseur, cliënt, opdrachtgever). 


\subsection{Resultaten van het onderzoek}

Kernvraag 1a luidde: In welke mate heeft loopbaanbegeleiding invloed op de vijf ontwikkelaspecten, te weten: het zelfbeeld, de relatie met de werkomgeving, het functioneren, de communicatieve vaardigheden en de zelfsturing van de cliënt? Tabel 7.4 geeft een overzicht van de effecten die de loopbaanbegeleiding op de cliënt heeft gehad in de perceptie van de adviseur, alsmede van de cliënt zelf en in de perceptie van de opdrachtgever. De tabel laat zien dat de gemiddelde scores van zowel de adviseurs, als van de cliënten zelf en van hun opdrachtgevers (redelijk) hoog zijn. De adviseurs geven aan dat volgens hen het zelfbeeld van hun cliënten door de begeleiding het meest verbeterd is en daarnaast ook hun zelfsturend vermogen. De cliënten zelf vinden dat vooral hun zelfbeeld door de begeleiding is verbeterd. De opdrachtgevers vinden het functioneren het meest verbeterd door de begeleiding. Alle drie de bronnen vinden dat de communicatieve vaardigheden van de cliënten door de begeleiding het minst verbeterd zijn.

Kernvraag $1 \mathrm{~b}$ luidde: In welke mate heeft loopbaanbegeleiding invloed op de baantevredenheid van de cliënt? Tabel 7.4 laat zien dat de baantevredenheid van de cliënten met een gemiddelde van $M=3,55$ (schaal $1-5$ ) redelijk hoog is. De relatief grote spreiding $(S D=0,98)$ geeft wel aan dat de baantevredenheid in de perceptie van een aantal cliënten hoog is, maar van anderen juist laag.

Kernvraag 1c luidde: In welke mate heeft loopbaanbegeleiding invloed op de tevredenheid met de begeleiding van de cliënt en op de tevredenheid met de begeleiding van de opdrachtgever op de korte en middellange termijn? Het effect van de loopbaanbegeleiding op de tevredenheid van de cliënt en van de opdrachtgever op de korte en middellange termijn werd op twee manieren geanalyseerd: 1) op basis van de directe vraag naar de tevredenheid en 2) op basis van de Net Promotor Score (NPS). 
Tabel 7.4

Gemiddelden, standaarddeviaties en frequenties van de vijf verbeteraspecten en de baantevredenheid van de cliënt zelf, en in de perceptie van de adviseur en de perceptie van de opdrachtgever.

Ontwikkelaspecten

(plus baantevredenheid indien relevant)

$M \quad S D$

Cliënt, in de perceptie van de adviseur

\begin{tabular}{llll}
\hline Zelfbeeld & 3,96 & 0,55 & 128 \\
Relatie met werkomgeving & 3,48 & 0,76 & 128 \\
Functioneren & 3,51 & 0,69 & 128 \\
Communicatieve vaardigheden & 3,27 & 0,73 & 128 \\
Zelfsturend vermogen & 3,85 & 0,80 & 128 \\
\hline
\end{tabular}

\section{Cliënt zelf}

\begin{tabular}{lccc}
\hline Zelfbeeld & 4,13 & 0,68 & 128 \\
Relatie met werkomgeving & 3,39 & 0,89 & 128 \\
Functioneren & 3,51 & 0,87 & 128 \\
Communicatieve vaardigheden & 3,17 & 0,93 & 128 \\
Zelfsturend vermogen & 3,63 & 0,95 & 128 \\
Baantevredenheid & 3,55 & 0,98 & 128 \\
\hline \multicolumn{1}{c}{ Cliënt, in de perceptie van de opdrachtgever } & \\
\hline Zelfbeeld & n.v.t. & n.v.t. & n.v.t. \\
Relatie met werkomgeving & 4,00 & 1,23 & 96 \\
Functioneren & 4,02 & 1,35 & 96 \\
Communicatieve vaardigheden & 3,79 & 1,27 & 96 \\
Zelfsturend vermogen & n.v.t. & n.v.t. & n.v.t. \\
\hline
\end{tabular}

Noot. Schaal $=1-5$.

\section{1) Directe vraag naar de tevredenheid}

Tabel 7.5 laat zien dat de tevredenheid van de cliënt met de loopbaanbegeleiding op zowel de korte als de middellange termijn hoog is, respectievelijk $M=$ 
8,45 en $M=8,44$ (schaal $1-10$ ). Dit betekent dat de tevredenheid van de cliënt met de begeleiding over de tijd gemeten (gemiddeld meer dan drieënhalf jaar) zeer stabiel is. Ook in de perceptie van de adviseurs is de tevredenheid van de cliënt met de begeleiding hoog, zij het iets minder hoog dan die van de cliënt zelf: $M=8,05$ (gemeten op T2; eveneens met schaal 1 - 10). In de perceptie van de opdrachtgever is de tevredenheid van de cliënt met de begeleiding nog iets minder hoog, maar nog steeds aanzienlijk: $M=7,80$ (eveneens gemeten op T2; schaal $1-10$ ). Zowel de scores van de cliënten zelf als de percepties van deze tevredenheid bij de opdrachtgevers vertonen wel een vrij grote spreiding, wat aangeeft dat de tevredenheid met de begeleiding zowel bij de cliënten als in de perceptie van de opdrachtgevers nogal uiteenloopt. Ten slotte blijkt ook dat de opdrachtgevers zeer tevreden zijn met de begeleiding van hun medewerker(s) door de loopbaanadviseur. Opvallend is dat deze tevredenheid is toegenomen van $M=8,44$ op T1 naar $M=8,80$ op T2. De opdrachtgever blijkt dus zowel op korte als op middellange termijn zeer tevreden met de begeleiding van de cliënt door de betreffende adviseur.

\section{2) Net Promotor Score}

Tabel 7.6 geeft de resultaten van NPS (Reichheld, 2003) voor de tevredenheid van de cliënt in de perceptie van de adviseur, van de cliënt zelf en van de opdrachtgever zelf en in de perceptie van de opdrachtgever inzake de tevredenheid van de cliënt. Opvallend is dat alle gemiddelde scores positief uitvallen. Dat betekent dat er van ontevreden cliënten en opdrachtgevers nauwelijks sprake is. Er is zelfs driemaal sprake van een zeer hoge score: $\left.{ }^{7} 1\right)$ de score van de cliënt op de korte termijn (T1); 2) de score van de cliënt op de middellange termijn (T2); en 3) de score van de adviseur op middellange termijn (T2).

\footnotetext{
${ }^{7}$ Reichheld (2003) geeft een score $>50$ punten het judicium 'uitmuntend'.
} 
Tabel 7.5

Mate van tevredenheid van de cliënt met de begeleiding, alsmede in de perceptie van de adviseur en de opdrachtgever, alsook de mate van tevredenheid van de opdrachtgever met de adviseur.

\begin{tabular}{llll}
\hline Niveau/termijn & $M$ & $S D$ & $N$
\end{tabular}

Tevredenheid cliënt met begeleiding, perceptie adviseur,

(excl. generieke formulieren)

\begin{tabular}{lccc}
\hline Adviseur: CMI-niveau A & 8,12 & 0,91 & $20(16 \%)$ \\
Adviseur: CMI-niveau B & 7,98 & 0,78 & $64(50 \%)$ \\
Adviseur: CMI-niveau C & 8,09 & 0,68 & $44(34 \%)$ \\
Totaal: CMI-niveau A, B en C & 8,05 & 0,96 & $128(100 \%)$ \\
\hline
\end{tabular}

Tevredenheid cliënt met begeleiding, perceptie adviseur,

(incl. generieke formulieren)

$8,17 \quad 0,77 \quad 161$

Tevredenheid cliënt zelf met begeleiding

\begin{tabular}{lccc}
\hline Op korte termijn & 8,45 & 1,12 & 120 \\
Op middellange termijn & 8,44 & 1,14 & 128 \\
\hline
\end{tabular}

Tevredenheid cliënt met begeleiding, perceptie opdrachtgever

\begin{tabular}{llll}
\hline Op middellange termijn & 7,80 & 1,09 & 96 \\
\hline
\end{tabular}

Tevredenheid opdrachtgever met adviseur

\begin{tabular}{lccc}
\hline Op korte termijn & 8,44 & 0,68 & 68 \\
Op middellange termijn & 8,80 & 0,89 & 96 \\
\hline
\end{tabular}

Noot. De percepties van de adviseurs en opdrachtgevers van de tevredenheid van de cliënt met de begeleiding zijn alleen gemeten op de middellange termijn. 
In de perceptie van de adviseurs is de tevredenheid van hun cliënten hoog. De NPS-score ligt boven 50 punten. Dat wil zeggen dat de begeleiding in de perceptie van de adviseur over de tevredenheid van de cliënt, in de terminologie van Reichheld (2003), 'uitmuntend' beoordeeld wordt. Ook de cliënten geven de kwaliteit van de begeleiding zowel op T1 als op T2 het judicium uitmuntend, wat betekent dat zij 'met een goed gevoel de adviseur aanbevelen bij vrienden en collegae'. De cliëntenenquête (T2) geeft de hoogste NPS-score (60 punten) voor tevredenheid aan. Dat betekent dat cliënten vele malen een negen of tien punten als beoordeling hebben gegeven. Ook de opdrachtgevers geven zowel op de korte termijn (T1) als op de middellange termijn (T2) een positieve NPS-score, maar steeds met een score lager dan 50 punten.

Tabel 7.6

Net Promotor Scores: de tevredenheidsmetingen per meetmoment en bron.

\begin{tabular}{lcccccc}
\hline \multirow{2}{*}{ Deelnemer } & $\begin{array}{c}\text { Soort } \\
\text { beoordeling }\end{array}$ & $\begin{array}{c}\text { Perceptie/ } \\
\text { zelf }\end{array}$ & $\mathrm{T}$ & $N$ & NPS & Score \\
\hline Adviseur & Enquête & Perceptie & $\mathrm{T} 2$ & 225 & +51 & Uitmuntend \\
Cliënt & Verklaring & Zelf & $\mathrm{T} 1$ & 120 & +58 & Uitmuntend \\
Cliënt & Enquête & Zelf & $\mathrm{T} 2$ & 129 & +60 & Uitmuntend \\
Opdrachtgever & Enquête vr1 & Perceptie & $\mathrm{T} 2$ & 97 & +12 & Positief \\
Opdrachtgever & Enquête vr2 & Zelf & $\mathrm{T} 2$ & 96 & +8 & Positief \\
Opdrachtgever & Verklaring & Zelf & $\mathrm{T} 1$ & 72 & +31 & Positief \\
\hline
\end{tabular}

Naast de score zijn door de cliënten en opdrachtgevers ook tekstuele toelichtingen op hun tevredenheid met de begeleiding gegeven. Deze 'motivatie' van de score kan volgens Reichheld (2003) het resultaat van de NPS positief (maar ook negatief) beïnvloeden. Omdat het NPS-resultaat in het onderhavige onderzoek 
bijzonder hoog was, zijn alleen de hoogste scores van de 'motivaties' als voorbeelden van de tekstuele toelichtingen voor zowel de cliënten als de opdrachtgevers in Bijlage 7A opgenomen. De voorbeelden van de toelichtingen geven aan dat er door de cliënten en opdrachtgevers een breed scala aan verschillende 'motieven' gebruikt werd om hun score toe te lichten.

Kernvraag 2 luidde: Welke samenhang is er tussen de vijf ontwikkel-aspecten onderling, vanuit het gezichtspunt van de adviseur, van de cliënt zelf en van de opdrachtgever. Tabel 7.7 tot en met 7. 9 geven een overzicht van deze samenhang.

Tabel 7.7 laat zien dat vanuit het gezichtspunt van de adviseur de correlaties tussen alle vijf ontwikkelaspecten significant zijn. De verbetering van het zelfbeeld en de zelfsturing van de cliënt zijn hierbij volgens de adviseur het sterkst aan elkaar gerelateerd $(r=0,45 ; p<0,001)$. Ook hangt de verbetering van de relatie met de werkomgeving sterk samen met de verbetering van het zelfbeeld $(r=0,38 ; p<0,001)$ en eveneens met de verbetering van het functioneren $(r=0,39 ; p<0,001)$.

Tabel 7.7

De onderlinge relatie tussen de vijf verbeteraspecten in de perceptie van de adviseur.

\begin{tabular}{lcccccc}
\hline \multicolumn{1}{c}{ Verbeteraspect } & $M$ & $S D$ & 1 & 2 & 3 & 4 \\
\hline Zelfbeeld & 3,96 & 0,55 & - & & & \\
Relatie werkomgeving & 3,48 & 0,76 & $0,38^{* * *}$ & - & & \\
Functioneren & 3,51 & 0,69 & $0,34^{* * *}$ & $0,39^{* * *}$ & - & \\
Communicatieve vaardigheden & 3,27 & 0,73 & $0,26^{* *}$ & $0,32^{* * *}$ & $0,21^{*}$ & - \\
Zelfsturend vermogen & & & & & & \\
& 3,85 & 0,80 & $0,45^{* * *}$ & $0,26^{* *}$ & $0,27^{* *}$ & $0,33^{* * *}$ \\
\hline
\end{tabular}

Noot. ${ }^{*} p<0,05,{ }^{* *} p<0,01,{ }^{* *} p<0,001$ (tweezijdig). $N=128$. 
Tabel 7.8 laat zien dat vanuit het gezichtspunt van de cliënt de verbetering van alle vijf ontwikkelaspecten onderling significant met elkaar samenhangt. Hierbij blijken de verbetering van het functioneren van de cliënt en het verbeteren van de relatie met de werkomgeving het sterkst te correleren $(r=0,65 ; p<0,01)$. Blijkbaar is volgens de cliënt de verbetering van het eigen functioneren sterk gerelateerd aan de verbetering van zijn of haar relatie met de werkomgeving.

Tabel 7.8

De onderlinge relatie tussen de vijf ontwikkelaspecten vanuit het gezichtspunt van de cliënt zelf.

\begin{tabular}{lcccccc}
\hline Ontwikkelaspect & $M$ & $S D$ & 1 & 2 & 3 & 4 \\
\hline Zelfbeeld & 4,13 & 0,68 & - & & & \\
Relatie werkomgeving & 3,39 & 0,89 & $0,40^{* *}$ & - & & \\
Functioneren & 3,51 & 0,87 & $0,40^{* *}$ & $0,65^{* *}$ & - & \\
Communicatieve vaardigheden & 3,17 & 0,93 & $0,44^{* *}$ & $0,43^{* *}$ & $0,46^{* *}$ & - \\
Zelfsturend vermogen & & & & & & \\
& 3,55 & 0,95 & $0,35^{* *}$ & $0,21^{*}$ & $0,32^{* *}$ & $0,49^{* *}$ \\
\hline
\end{tabular}

Noot. ${ }^{*} p<0,05,{ }^{* *} p<0,01,{ }^{* * *} p<0,001$ (tweezijdig). $N=127$.

Tabel 7.9 geeft een overzicht van de correlaties tussen de onderlinge verbetering van de drie ontwikkelaspecten in de perceptie van de opdrachtgever ${ }^{8}$. De tabel laat zien dat de relaties tussen de verbetering in de communicatieve vaardigheden, het functioneren en de relatie met de werkomgeving van de cliënt in de perceptie van de opdrachtgever alle drie sterk en significant zijn (respectievelijk: $r=0,95 ; 0,83$ en 0,$81 ;$ alle drie $p<0,01)$.

${ }^{8}$ Zie ook Design: 7.2.1. 
Tabel 7.9

De onderlinge relatie tussen de drie verbeteraspecten in de perceptie van de opdrachtgever.

\begin{tabular}{lcccccc}
\hline Verbeteraspect & $M$ & $S D$ & 1 & 2 & 3 & 4 \\
\hline Zelfbeeld & - & - & & & \\
Relatie werkomgeving & 4,62 & 1,98 & - & & & \\
Functioneren & 4,23 & 1,83 & - & $0,81^{* *}$ & \\
Communicatieve vaardigheden & 4,00 & 1,87 & - & $0,83^{* *}$ & $0,95^{* *}$ \\
Zelfsturend vermogen & - & - & - & - & - & - \\
\end{tabular}

Noot. ${ }^{*} p<0,05,{ }^{* *} p<0,01,{ }^{* * *} p<0,001$ (tweezijdig). $N=13$.

Kernvraag 3 luidde: Is er een relatie tussen de tevredenheid van zowel de cliënt als de opdrachtgever met de begeleiding op de korte termijn en die op de middellange termijn en hoe sterk is die relatie? Tabel 7.10 geeft een overzicht van de tevredenheid van zowel de cliënt als de opdrachtgever met de begeleiding op de korte en middellange termijn. De tabel laat zien dat er een zeer sterke correlatie is tussen de tevredenheid van de cliënten met de begeleiding op de korte en de middellange termijn: $r=0,65 ; p<0,001$. Dit betekent dat de tevredenheid van de cliënten over de loopbaanbegeleiding de eerste drieënhalf jaar na de begeleiding behoorlijk stabiel is.

Ook is er een stabiele positieve significante relatie tussen de tevredenheid van de opdrachtgevers met de begeleiding van de adviseurs op de korte en middellange termijn: $r=0,28 ; p<0,01$. Eveneens is er een significante positieve correlatie tussen de tevredenheid van de cliënt en die van de opdrachtgever op T1: $r=0,64 ; p<0,05$. Dit betekent dat, naarmate een cliënt tevredener is, een opdrachtgever vaak ook 
tevredener is. De relatie tussen de tevredenheid over de begeleiding van de cliënt zelf en die van de opdrachtgever is op T2 echter wel minder sterk dan op T1 ( $r=$ $0,24 ; p=0,45)$. Dat zou kunnen betekenen dat na verloop van tijd de tevredenheid van de cliënt en die van de opdrachtgever over de begeleiding enigszins uiteen gaan lopen.

Tabel 7.10

Correlaties tussen de tevredenheid van de cliënt met de begeleiding en de tevredenheid van de opdrachtgever met de adviseur, op korte termijn en middellange termijn.

$\begin{array}{llll}1 & 2 & 3 & 4\end{array}$

Cliënt (T1)

Cliënt (T2)

$0,65^{* * *}$

$(N=116)$

Opdrachtgever (T1)

$$
0,64^{*}
$$

0,42

$$
(N=10)
$$$$
(N=13)
$$

Opdrachtgever (T2)

$$
0,33
$$

0,24

$0,28^{* *}$

$$
(N=13)
$$

$(N=12)$

$(N=65)$

Noot. ${ }^{*} p<0,05 ;{ }^{* *} p<0,01 ;{ }^{* * *} p<0,001$.

Sterkteladder: In Tabel 7.11 worden de hiervoor besproken relaties tussen de verschillende tevredenheidsmetingen weergegeven in volgorde van de sterkte van de relatie tussen de percepties van cliënt, opdrachtgever en adviseur, op T1 en T2, met de zogenaamde sterkteladder. In navolging van Field (2000) ${ }^{9}$ wordt de sterkte van de correlaties van $r>0,50$ aangeduid met 'groot'; die van $r=0,30-0,50$ met

\footnotetext{
${ }^{9}$ Field (2000) gaat uit van de navolgende vier sterkte indelingen: 0,00-0,10;0,10-0,30;0,30-0,50 en $>0,50$.
} 
'aanzienlijk'; die van $r=0,10-0,30$ met 'matig' en die van $r=0,00-0,10$ met 'weinig tot geen' ${ }^{\prime 10}$. Als belangrijkste resultaten laat de sterkteladder in Tabel 7.11 zien:

1) dat de correlatie tussen de tevredenheid met de begeleiding van de cliënt zelf op de korte termijn (T1) en middellange termijn (T2) het sterkst is. Dat betekent dat de tevredenheid van de cliënt over de tijd van gemiddeld drieënhalf jaar zeer stabiel is;

2) dat de op één na sterkste relatie die is tussen de tevredenheid van de cliënt zelf op T1 en de tevredenheid van de opdrachtgever met de begeleiding door de adviseur op T1;

3) dat er een aanzienlijke, maar niet significante, relatie is tussen de tevredenheid van de cliënt zelf op T2 en de tevredenheid van de cliënt in de perceptie van de opdrachtgever op T2. Hoewel dit een sterke relatie is, is deze dus aanzienlijk lager dan die op T1;

4) dat er een aanzienlijke, maar niet significante relatie is tussen de tevredenheid van de cliënt zelf (T2) en de tevredenheid van de opdrachtgever zelf over de begeleiding door de adviseur (T1);

5) dat er een aanzienlijk sterke, significante relatie is tussen de tevredenheid van opdrachtgever zelf op T1 en T2;

6) dat er ook een aanzienlijk sterke, significante relatie is tussen de tevredenheid over de begeleiding van de cliënt in de perceptie van de opdrachtgever (T2) en de tevredenheid van de opdrachtgever zelf over de begeleiding van de adviseur (T2).

\footnotetext{
${ }^{10}$ In het onderhavige onderzoek is het aantal 'matches' $(N)$ tussen de cliënt, de adviseur en de opdrachtgever in sommige gevallen gering. Dit heeft invloed op de mate van significantie van de relatie: in sommige gevallen is de relatie aanzienlijk, maar niet significant. Het is mogelijk dat bij een groter aantal waarnemingen deze bevindingen wel significant zouden zijn.
} 
Tabel 7.11

Sterkteladder: De sterkte van de onderlinge samenhang tussen de perceptie van tevredenheid van de adviseur, de cliënt zelf en de perceptie van de opdrachtgever (zelf), op T1 en T2.

\begin{tabular}{|c|c|c|c|c|c|}
\hline Hiërarchie & Tevredenheid I & Tevredenheid II & $R$ & $N$ & Sterkte \\
\hline \multirow[t]{2}{*}{1} & Cliënt & Client & $0,65^{* * *}$ & 117 & Zeer groot \\
\hline & (T1; zelf) & (T2; zelf) & & & \\
\hline \multirow[t]{2}{*}{2} & Cliënt & Opdrachtgever & $0,64^{*}$ & 10 & Zeer groot \\
\hline & (T1; zelf) & (T1; zelf) & & & \\
\hline \multirow[t]{2}{*}{3} & Cliënt & Opdrachtgever & 0,44 & 12 & Aanzienlijk \\
\hline & (T2; zelf) & (T2; perceptie) & & & \\
\hline \multirow[t]{2}{*}{4} & Cliënt & Opdrachtgever & 0,42 & 13 & Aanzienlijk \\
\hline & (T2; zelf) & $(\mathrm{T} 1 ;$ zelf $)$ & & & \\
\hline \multirow[t]{2}{*}{5} & Opdrachtgever & Opdrachtgever & $0,38^{* *}$ & 65 & Aanzienlijk \\
\hline & (T1; zelf) & (T2; zelf) & & & \\
\hline \multirow[t]{2}{*}{6} & Opdrachtgever & Opdrachtgever & $0,34^{* * *}$ & 97 & Aanzienlijk \\
\hline & (T2; zelf) & (T2; perceptie) & & & \\
\hline \multirow[t]{2}{*}{7} & Cliënt & Opdrachtgever & 0,33 & 11 & Matig \\
\hline & (T1; zelf) & (T2; zelf) & & & \\
\hline \multirow[t]{2}{*}{8} & Cliënt & Opdrachtgever & 0,24 & 12 & Matig \\
\hline & (T2; zelf) & (T2; zelf) & & & \\
\hline \multirow[t]{2}{*}{9} & Opdrachtgever & Adviseur & $0,23^{*}$ & 97 & Matig \\
\hline & (T2; perceptie) & (T2; perceptie) & & & \\
\hline \multirow[t]{2}{*}{10} & Cliënt & Adviseur & $0,17+$ & 127 & Weinig / \\
\hline & (T2; zelf) & (T2; perceptie) & & & Geen \\
\hline \multirow[t]{2}{*}{11} & Cliënt & Opdrachtgever & 0,15 & 12 & Weinig / \\
\hline & $(T 1 ;$ zelf $)$ & (T2; perceptie) & & & Geen \\
\hline \multirow[t]{2}{*}{12} & Cliënt & Adviseur & 0,08 & 116 & Weinig / \\
\hline & (T1; zelf) & (T2; perceptie) & & & Geen \\
\hline
\end{tabular}




\begin{tabular}{cccccc}
\hline 13 & Opdrachtgever & Adviseur & 0,07 & 97 & Weinig / \\
& $(T 2 ;$ zelf $)$ & $($ T2; perceptie $)$ & & & Geen \\
\hline 14 & Opdrachtgever & Opdrachtgever & 0,06 & 65 & Weinig / \\
& $(T 1 ;$ zelf $)$ & $($ T2; perceptie $)$ & & & Geen \\
\hline 15 & Opdrachtgever & Adviseur & $-0,02$ & 68 & Weinig / \\
& $(T 1 ; z$ elf $)$ & $($ T2; perceptie $)$ & & & Geen \\
\hline
\end{tabular}

Noot. ${ }^{*} p<0,05 ;{ }^{* *} p<0,01 ;{ }^{* * *} p<0,001 ;+p<0,10$ (tweezijdig).

Kernvraag 4a luidde: Is er een relatie tussen de tevredenheid van de cliënt met de begeleiding en de vijf ontwikkelaspecten van de cliënt? Voor het beantwoorden van deze vraag werd een regressieanalyse uitgevoerd, met de vijf ontwikkelaspecten als onafhankelijke variabelen en de tevredenheid van de cliënt op de middellange termijn als afhankelijke variabele. Uit de regressieanalyse bleek dat de tevredenheid van de cliënt met de begeleiding op de middellange termijn inderdaad significant verklaard wordt door de ontwikkelaspecten tezamen $\left(R^{2}=0,33 ; p<0,001\right)$.

De tevredenheid van de cliënten wordt voor 33\% verklaard door de verbetering van het zelfbeeld en de verbetering van het functioneren van de cliënt. Tabel 7.12 laat zien dat in deze resultaten de verbetering van het zelfbeeld volgens de cliënt de grootste rol speelt: $(\beta=0,41 ; p<0,001)$, gevolgd door de verbetering van het functioneren $(\beta=0,29 ; p<0,01)$.

De verbetering van de relatie met de werkomgeving, de verbetering van de communicatie en de verbetering van het zelfsturend vermogen leiden niet tot een significante toename van de tevredenheid van de cliënt over de begeleiding op de middellange termijn (zie Tabel 7.12). 
Tabel 7.12

Regressie van de tevredenheid van de cliënt met de begeleiding op middellange termijn

op de vijf ontwikkelaspecten.

\begin{tabular}{|c|c|c|c|c|c|}
\hline $\begin{array}{c}\text { Tevredenheid cliënt, } \\
\text { op middellange termijn (T2) }\end{array}$ & $B$ & $S E$ & $\beta$ & $R^{2}$ & $F$ \\
\hline & & & & 0,33 & $12,24^{* * *}$ \\
\hline Zelfbeeld & 0,70 & 0,15 & $0,41^{* * *}$ & & \\
\hline Relatie werkomgeving & $-0,14$ & 0,13 & $-0,11$ & & \\
\hline Functioneren & 0,37 & 0,13 & $0,29^{* *}$ & & \\
\hline Communicatieve vaardigheden & 0,08 & 0,12 & 0,06 & & \\
\hline Zelfsturend vermogen & 0,04 & 0,11 & 0,04 & & \\
\hline
\end{tabular}

Noot. $D f=(5,122)$; totaal $d f=127 .{ }^{*} p<0,05 .{ }^{* *} p<0,01 ;{ }^{* *} p<0,001$.

Kernvraag 4b luidde: Is er een relatie tussen de tevredenheid van de cliënt met de begeleiding en diens baantevredenheid? Voor het beantwoorden van deze vraag werd een correlatieanalyse uitgevoerd.

Tabel 7.13 laat zien dat de tevredenheid van de cliënt met diens (nieuwe) baan op de korte termijn significant samenhangt met diens tevredenheid over de begeleiding: $r=0,25 ; p<0,01$. Op middellange termijn bleek de tevredenheid van de cliënt met diens nieuwe baan zelfs nog sterker samen te hangen met tevredenheid met de ontvangen begeleiding: $r=0,43 ; p<0,001$. 
Tabel 7.13

Gemiddelden en standaarddeviaties van en de relatie tussen de tevredenheid van de cliënt op korte en middellange termijn en de baantevredenheid van de cliënt.

\begin{tabular}{|c|c|c|c|c|c|}
\hline & $M$ & $S D$ & 1 & 2 & 3 \\
\hline $\begin{array}{l}\text { Tevredenheid cliënt met begeleiding, } \\
\text { korte termijn (T1) }\end{array}$ & 8,45 & 1,12 & - & & \\
\hline $\begin{array}{l}\text { Tevredenheid cliënt met begeleiding, } \\
\text { middellange termijn (T2) }\end{array}$ & 8,44 & 1,14 & $0,65^{\text {***}}$ & - & \\
\hline Baantevredenheid cliënt (T2) & 3,55 & 0,98 & $0,25^{* *}$ & $0,43^{* * *}$ & - \\
\hline
\end{tabular}

Noot 1. ${ }^{* *} p<0,01,{ }^{* * *} p<0,001$ (tweezijdig).

Noot 2. De schaal voor de tevredenheid van de cliënt met de begeleiding is van $1-10$ en die voor baantevredenheid van $1-5$.

Kernvraag 5a luidde: Is er een relatie tussen de vijf ontwikkelaspecten van de cliënt en diens baantevredenheid? Voor het beantwoorden van vraag 5a werd een regressieanalyse uitgevoerd, met de vijf ontwikkelaspecten als onafhankelijke variabelen en de baantevredenheid van de cliënt als afhankelijke variabele.

Tabel 7.14 laat zien dat de baantevredenheid van de cliënt voor 44\% verklaard wordt door de verbetering van de vijf ontwikkelaspecten tezamen $\left(R^{2}=0,44 ; p<\right.$ 0,001). Daarbij heeft de verbetering van het functioneren $(\beta=0,45 ; p<0,001)$ de grootste invloed op de baantevredenheid van de cliënt. Het effect van de verbetering van de relatie met de werkomgeving op de baantevredenheid is marginaal significant $(\beta=0,15, p<0,10)$. 
De verbetering van het zelfbeeld, de communicatieve vaardigheden en de zelfsturing verklaren de baantevredenheid van de cliënt niet (geen significante relatie).

Tabel 7.14

Regressie van de baantevredenheid van de cliënt op de vijf ontwikkelaspecten.

\begin{tabular}{|c|c|c|c|c|c|}
\hline Baantevredenheid cliënt (T2) & $B$ & $S E$ & $B$ & $R^{2}$ & $F$ \\
\hline & & & & 0,44 & $19,11^{* * *}$ \\
\hline Zelfbeeld & 0,11 & 0,12 & 0,08 & & \\
\hline Relatie werkomgeving & 0,17 & 0,10 & $0,15+$ & & \\
\hline Functioneren & 0,51 & 0,11 & $0,45^{* * *}$ & & \\
\hline Communicatieve vaardigheden & 0,02 & 0,09 & 0,02 & & \\
\hline Zelfsturend vermogen & 0,13 & 0,09 & 0,13 & & \\
\hline
\end{tabular}

Noot. ${ }^{* *} p<0,01 ;{ }^{* *} p<0,001 ;+p<0,10 . D f=(5 ; 122)$; Totaal $d f=127$.

Kernvraag 5b luidde: is er een relatie tussen de vijf afzonderlijke ontwikkelaspecten van de cliënt en diens baantevredenheid? Om een antwoord te geven op kernvraag $5 b$ geeft Tabel 7.15 een overzicht van de relaties tussen de baantevredenheid en de vijf ontwikkelaspecten van de cliënt. De tabel laat zien dat de baantevredenheid van de cliënt drieënhalf jaar na de begeleiding significant gerelateerd is aan alle vijf ontwikkelaspecten in het kader van de loopbaanontwikkeling van de cliënt. 
Tabel 7.15

De relatie tussen de baantevredenheid op de middellange termijn

en de vijf afzonderlijke ontwikkelaspecten van de client ( $r$ ).

\begin{tabular}{lc}
\hline & Baantevredenheid \\
\hline Zelfbeeld & $0,36^{* *}$ \\
Relatie werkomgeving & $0,48^{* *}$ \\
Functioneren & $0,58^{* *}$ \\
Comm vaardigheden & $0,30^{* *}$ \\
Zelfsturend vermogen & $0,34^{* *}$ \\
\hline
\end{tabular}

${ }^{*} p<0,05 ;{ }^{* *} p<0,01 ;{ }^{* *} p<0,001$.

Kernvraag 6a luidde: Is er een relatie tussen het CMI-niveau van de adviseur en de vijf ontwikkelaspecten van de cliënt? Voor het beantwoorden van deze vraag zijn Spearman's correlatieanalyses uitgevoerd vanwege het ordinale karakter van de variabele (het CMI-niveau). Er blijkt, afgezien van de communicatieve vaardigheden, geen relatie te zijn tussen het CMI-niveau van de adviseur en de ontwikkelaspecten van de cliënt, zoals Tabel 7.16 laat zien. Voor de communicatieve vaardigheden blijkt er een marginale relatie met het CMI-niveau van de adviseur te zijn. Dat wil zeggen dat de adviseur die werkzaam is op een smaller CMI-niveau de cliënt het beste kan begeleiden voor wat de ontwikkeling van hun communicatieve vaardigheden betreft.

Kernvraag $6 \mathrm{~b}$ luidde: Is er een relatie tussen het CMI-niveau van de adviseur en de baantevredenheid van de cliënt? Om een antwoord te kunnen geven op deze kernvraag werd een Spearman's correlatieanalyse uitgevoerd voor de relatie tussen de baantevredenheid van de cliënt en het CMI-niveau van de adviseur. Het valt ook in Tabel 7.16 op dat het CMI-niveau van de adviseur geen samenhang vertoont met 
de baantevredenheid van de cliënt: $r=-0,12 ; p=n s$ (bij $N=127)$. Er is dus ook geen relatie tussen het CMI-niveau van de adviseur en de baantevredenheid van de cliënt.

Kernvraag 6c luidde: Is er een relatie tussen het CMI-niveau van de adviseur en de tevredenheid van de cliënt met de begeleiding op de korte en middellange termijn? Om een antwoord te kunnen geven op deze kernvraag vermeldt Tabel 7.16 de uitkomsten van de correlatieanalyses (Spearman) voor de relaties tussen de tevredenheid van de cliënt over de begeleiding op de korte en middellange termijn en het CMI-niveau van de adviseur. Zowel op de korte als op de middellange termijn is deze correlatie niet significant.

\section{Tabel 7.16}

De relatie tussen het CMI-niveau van de adviseur en de ontwikkelaspecten, baantevredenheid en tevredenheid cliënt met de begeleiding op korte en middellange termijn (rho).

\begin{tabular}{lc}
\hline & CMI-niveau \\
\hline Zelfbeeld & 0,00 \\
Relatie werkomgeving & 0,07 \\
Functioneren & 0,08 \\
Comm vaardigheden & $-0,16+$ \\
Zelfsturend vermogen & 0,03 \\
Baantevredenheid & $-0,12$ \\
Tevredenheid cliënt op & 0,00 \\
$\quad$ korte termijn $(\mathrm{T} 1)$ & 0,05 \\
Tevredenheid cliënt op & \\
middellange termijn $(\mathrm{T} 2)$ & \\
\hline${ }^{*} p<0,05 ; * * 0,01 ; * * p<0,001 ;+\mathrm{p}<0,10$.
\end{tabular}


Kernvraag 7 luidde: Is er een relatie tussen de vijf ontwikkelaspecten van de cliënt en de achtergrondvariabelen (gender, leeftijd, opleiding en specifieke werkervaring) van de adviseur? Om een antwoord te kunnen geven op kernvraag 7 zijn opnieuw correlatieanalyses (Pearson en Spearman) uitgevoerd voor de verschillende relaties tussen de achtergrondvariabelen en de vijf ontwikkelaspecten van de cliënt.

Gender: Uit Tabel 7.17 valt af te lezen dat er een significante relatie bestaat tussen gender van de adviseur en de verbetering van het zelfbeeld van de cliënt, namelijk $r=0,24 ; p=0,02$. Dat betekent dat vrouwelijke adviseurs over het algemeen een iets grotere verbetering in het zelfbeeld van de cliënt teweegbrengen dan mannelijke adviseurs. Ook hebben vrouwelijke adviseurs een iets grotere verbetering van de relatie met de werkomgeving bewerkstelligd dan hun mannelijke collegae, maar dit effect is slechts marginaal significant $(r=0,18 ; p=0,06)$. Voor gender zijn er verder geen relaties gevonden met de andere drie ontwikkelaspecten.

Leeftijd: Uit Tabel 7.17 blijkt voorts dat jongere adviseurs het zelfbeeld van de cliënt beter weten te verbeteren dan hun oudere collegae $(r=-0,18 ; p<0,01)$. Ook is er een marginaal significante negatieve relatie tussen leeftijd en effectief communiceren. Ook hier zijn juist de jongere adviseurs iets succesvoller als het gaat om het verbeteren van de communicatieve vaardigheden van hun cliënten $(r=-0,18$; $p<0,01)$ dan hun oudere collegae.

Opleiding: Tussen wo-opgeleide adviseurs en hun hbo-collegae zijn er geen significante verschillen in de mate waarin zij bijdragen aan de verschillende ontwikkelaspecten van hun cliënten.

Specifieke werkervaring: Ook de specifieke werkervaring van de adviseur blijkt geen relatie te hebben met de vijf ontwikkelaspecten van de cliënt. 
Tabel 7.17

Correlaties tussen achtergrondvariabelen adviseur en ontwikkelaspecten van de cliënt.

\begin{tabular}{lcccc}
\hline \multicolumn{1}{c}{ Ontwikkelaspect } & Gender & Leeftijd & Opleiding & $\begin{array}{c}\text { Specifieke } \\
\text { werkervaring }\end{array}$ \\
\hline Zelfbeeld & $0,24^{* *}$ & $-0,18^{*}$ & $-0,05$ & $-0,08$ \\
Werkomgeving & $0,18^{*}$ & 0,14 & $-0,04$ & $-0,13$ \\
Functioneren & 0,04 & 0,17 & 0,02 & $-0,04$ \\
Comm. Vaardigheden & 0,04 & & & $-0,14$ \\
Zelfsturing & $-0,18^{*}$ & $-0,05$ & $-0,07$ \\
\hline
\end{tabular}

Noot. ${ }^{* *} p<0,01,{ }^{*} p<0,10$ (tweezijdig).

\subsection{Discussie}

Hieronder zullen de belangrijkste bevindingen van dit onderzoek worden besproken vanuit de drie bronnen. De implicaties en beperkingen van het onderzoek en de daaruit voortvloeiende aanbevelingen voor de wetenschap en de praktijk zullen de revue passeren. Gezien het grote aantal variabelen, die al of niet met elkaar samenhangen, dient gerealiseerd te worden dat het steeds gaat om de kwaliteit van de effecten van de begeleiding. Daarbij worden de vijf ontwikkelaspecten en de tevredenheid van de cliënt en van de opdrachtgever met de begeleiding op korte en middellange termijn, als ook de tevredenheid van de cliënt met de veelal nieuwe baan besproken. 


\subsubsection{Bevindingen van het onderzoek}

Voor wat betreft de effecten van de begeleiding worden deze over het algemeen positief beoordeeld, veelal met hoge scores. Het blijkt dat loopbaanbegeleiding, volgens de cliënten zelf, een positieve invloed heeft op zowel de vijf ontwikkelaspecten van hun loopbaanproces als op hun baantevredenheid. Daarnaast blijkt dat de tevredenheid van de cliënt en van de opdrachtgever over de begeleiding in het algemeen behoorlijk hoog en stabiel blijft scoren, ook drieënhalf jaar na de begeleiding.

Voorts blijkt dat loopbaanadviseurs met een breder CMI-niveau niet beter of slechter presteren dan adviseurs met een smaller niveau. Dit geldt zowel voor de verbetering van de vijf ontwikkelaspecten, als voor de baantevredenheid en de tevredenheid van de cliënt met de begeleiding op de korte en middellange termijn. De enige uitzondering hierop is het ontwikkelaspect communicatieve vaardigheden, waarbij er een marginaal verschil is tussen de niveaus. Het smallere niveau (meest jongere adviseurs, die zelf de social media ook beter beheersen) begeleiden hun cliënten op het gebied van communicatieve vaardigheden een fractie beter dan adviseurs op een breder niveau.

Vijf ontwikkelaspecten

De verbetering van de vijf ontwikkelaspecten van de cliënt als gevolg van de begeleiding volgens de adviseur, de cliënt zelf en de opdrachtgever geeft zonder uitzondering een gemiddelde waarde hoger dan 3,0 op een vijfpuntsschaal. De adviseurs zijn van mening dat het zelfbeeld van de cliënten door de begeleiding het meest is verbeterd, gevolgd door de verbetering van het zelfsturend vermogen en het functioneren. Dat is in lijn met de bevindingen van Kidd, Jackson en Hirsh (2003) en Bernaud, Gaudron en Lemoine (2006), die de relatie van het zelfbeeld met zelfinzicht en zelfvertrouwen, zij het op korte termijn, onderzochten. In het 
onderhavige onderzoek werden de ontwikkel-aspecten gemiddeld drieënhalf jaar na de begeleiding onderzocht.

De communicatieve vaardigheden worden in de ogen van de adviseurs door de begeleiding het minst verbeterd. Het gebrek aan communicatieve vaardigheden is in de praktijk veelal de oorzaak van het minder functioneren. Door minder goede communicatieve vaardigheden van de medewerker/cliënt kan miscommunicatie ontstaan, die vervolgens in de ogen van de leidinggevenden/opdrachtgever het minder goede functioneren van de medewerker/cliënt veroorzaakt. Als gevolg van de begeleiding verbeteren de communicatieve vaardigheden in de ogen van de adviseur echter wel enigszins, waardoor ook het functioneren van de cliënt verbetert.

Volgens de cliënten zelf was hun zelfbeeld en ook het zelfsturend vermogen en het functioneren als gevolg van de begeleiding sterk verbeterd. Door de cliënt zelf wordt de verbetering van de communicatieve vaardigheden, evenals bij de adviseur, het minst hoog gescoord. Wel vindt de cliënt zelf een sterk significant verband tussen functioneren en de communicatieve vaardigheden van de medewerker/ cliënt.

In de literatuur wordt, naar het weten van de auteur van dit proefschrift, weinig tot geen aandacht besteed aan het functioneren van de cliënt. Dat is merkwaardig, omdat de reden voor de begeleiding veelal gezocht dient te worden in het minder functioneren van de cliënt in diens werkkring. Ook de verbetering van de relatie met de werkomgeving wordt in eerder onderzoek niet of nauwelijks genoemd als interventie voor loopbaanbegeleiding. Dat deze vijf ontwikkelaspecten door de cliënt zelf als sterk verbeterd gevonden worden, draagt sterk bij tot een positief oordeel over het vakgebied. Immers, bij loopbaanadvisering gaat het er juist om dat de interventies van de adviseur bij de cliënt verbeteringen brengen. 
De opdrachtgevers noemen het functioneren van de cliënten, naast de verbetering van de relatie met de werkomgeving, als het meest verbeterd. Opvallend is dat het oordeel van de opdrachtgevers over de verbetering van het functioneren van cliënten en ook het verbeteren van hun relatie met de werkomgeving zeer hoog uitvalt, maar mogelijk was het de opdrachtgever juist om deze twee aspecten te doen, toen de opdrachtgever het groene licht gaf voor de begeleiding.

\section{Baantevredenheid}

Ook laat dit onderzoek zien dat de tevredenheid van de cliënten met hun nieuwe baan bovengemiddeld scoort. De grote spreiding geeft echter aan dat deze conclusie genuanceerd dient te worden: blijkbaar is een deel van de cliënten zeer tevreden met de nieuwe werkkring, terwijl een ander deel hierover op zijn best slechts redelijk tevreden is. Een mogelijke verklaring hiervoor is dat het oordeel van de cliënt over de nieuwe baan pas gevraagd werd na circa drieënhalf jaar. In die periode kan veel gebeurd zijn, waardoor het enthousiasme over de nieuwe werkkring bij een deel van de cliënten is afgenomen. Voor andere cliënten is er, zoals het onderzoek van Bernaud et al. (2006) laat zien, duidelijk tevredenheid over de werkkring ontstaan na de loopbaanbegeleiding. Bij Bernaud et al. is dit echter een constatering over de tevredenheid inzake de baan op korte termijn.

Tevredenheid met de begeleiding op korte en middellange termijn

De tevredenheid van de cliënt zelf met de begeleiding is hoog, zowel op de korte als middellange termijn. De gemiddelde tevredenheid van de cliënt tussen beide meetmomenten (T1 en T2) blijkt vrijwel stabiel te zijn, wat over een periode van drieënhalf jaar opmerkelijk is. Deze bevinding is, wat de korte termijn betreft, in lijn met eerder longitudinaal onderzoek van Bernaud et al. (2006) en ook met Perdrix et al. (2012), die lieten zien dat de tevredenheid tijdens de begeleiding steeg 
en vervolgens een jaar lang stabiel bleef. Voor de middellange termijn is naar weten van de auteur van dit proefschrift de stabiliteit van de effecten echter nog niet eerder aangetoond.

Zowel op de korte termijn als middellange termijn blijkt ook de opdrachtgever zeer tevreden met de begeleiding door de adviseur, die zelfs een fractie hoger scoort op de middellange termijn dan op de korte termijn. De verklaring hiervoor zou kunnen zijn dat de opdrachtgever vaak meerdere malen werkt op basis van tevredenheid met dezelfde adviseur. Dit zou de grotere tevredenheid op T2 kunnen verklaren. Ook op basis van onderzoek met behulp van de NPS wordt bevestigd dat zowel vanuit het gezichtspunt van de adviseur, als van de cliënt, als van de opdrachtgever, de tevredenheid van de cliënt met de begeleiding hoog scoort. De kwalificatie uitmuntend wordt zelfs in het kader van NPS driemaal gegeven: tweemaal door de cliënt voor blijken van tevredenheid met de begeleiding op korte en middellange termijn en éénmaal door de adviseur in de perceptie van de tevredenheid van de cliënt op middellange termijn.

\section{Samenhang}

Vanuit het gezichtspunt van de adviseur hangen de vijf ontwikkelaspecten onderling sterk samen. Het onderzoek laat zien dat de verbetering van het functioneren van de cliënt en de verbetering van diens relatie met de werkomgeving, alsmede de verbetering van de relatie met de werkomgeving en de verbetering van het zelfbeeld het sterkste samenhangen. De communicatieve vaardigheden scoren ook in de onderlinge samenhang in de perceptie van de adviseur het laagst.

Voor de cliënt hangen de verbetering van het functioneren en de relatie met de werkomgeving het meeste samen, gevolgd door de verbetering van het zelfsturend vermogen en de communicatieve vaardigheden als mede de verbetering 
van het functioneren eveneens met de communicatieve vaardigheden. De cliënt zelf vindt dus dat de verbetering van het zelfbeeld het minst samenhangt met de andere ontwikkelaspecten, terwijl het zelfbeeld op zich vanuit het gezichtspunt van de cliënt gemiddeld het hoogste scoort, met de laagste spreiding. Opmerkelijk is ook dat vanuit het gezichtspunt van de cliënt de relatie van het zelfbeeld met het zelfsturend vermogen relatief laag scoort, terwijl de gemiddelde scores van het zelfbeeld en van het zelfsturend vermogen juist het dichtst bij elkaar liggen. De auteur van dit proefschrift heeft hier geen goede verklaring voor.

In de perceptie van de opdrachtgever is de samenhang tussen de verbetering van de communicatieve vaardigheden en de verbetering van het functioneren (veruit) het hoogste. Dat is in de perceptie van de opdrachtgevers ook begrijpelijk: als het functioneren verbetert, verbeteren ook de communicatieve vaardigheden en andersom. Daar is het de opdrachtgever bij de begeleiding om te doen. Ook alle gemiddelde scores van de genoemde ontwikkelaspecten scoren $>4,0$ en derhalve goed. Het onderzoek geeft dus aan dat alle vijf ontwikkelaspecten onderling, vanuit het gezichtspunt van de drie bronnen, significant samenhangen.

Het onderzoek is, naar weten van de auteur van dit proefschrift, de eerste poging om naast de korte termijn ook de middellange-termijneffecten van de begeleiding bij loopbaanadvisering te onderzoeken. De relatie tussen de tevredenheid van de cliënten op korte en middellange termijn is zeer sterk. Het vermoeden van Perdrix et al. (2012), dat de hoge tevredenheid op de korte termijn ook op middellange termijn standhoudt, is hiermee aangetoond.

Opvallend is vooral dat in dit onderzoek een hoge mate van stabiliteit tussen het korte termijn en het middellange-termijnresultaat, zowel bij de cliënt als bij de opdrachtgever, wordt aangetoond. Met betrekking tot de cliënt is hiervoor mogelijk de niet te onder-schatten emotionele impact van het loopbaanproces een verklaring, 
waardoor korte termijn impressies ook op de middellange termijn doorwerken. Maar ook de emotie rond het baanverlies zelf werkt blijkbaar lang door. Dat zou ook de verklaring kunnen zijn voor de gevonden stabiliteit in de tevredenheid. Ten slotte is het in het kader van de sterkteladder interessant dat de samenhang tussen de tevredenheid van de cliënt en de perceptie daarvan van de adviseur laag is. Dit betekent dat adviseurs de tevredenheid van hun cliënten over het algemeen niet erg goed kunnen inschatten.

De verbetering van het zelfbeeld en het functioneren van de cliënt verklaren tezamen de tevredenheid van de cliënt met de begeleiding op middellange termijn. Uit aanvullende regressieanalyses blijkt dat alle vijf de ontwikkelaspecten samenhangen met de tevredenheid van de cliënt over de begeleiding, maar kennelijk is de relatie tussen het verbeteren van het zelfbeeld en het functioneren van de cliënt met de tevredenheid over de begeleiding het sterkst. Het is mogelijk dat de cliënt de andere ontwikkelaspecten minder van belang vindt, waardoor deze twee ontwikkelaspecten het sterkst naar voren komen.

Uit het huidige onderzoek blijkt dat de baantevredenheid van de cliënt sterk samenhangt met de tevredenheid van de cliënt over de begeleiding op zowel de korte als de middellange termijn, waarbij de samenhang met de middellange termijn sterker is dan die met de korte termijn. Mogelijk is dit het gevolg van het feit dat hier de baantevredenheid op hetzelfde moment gemeten is als de tevredenheid van de cliënt over de begeleiding op middellange termijn.

Dit onderzoek wijst verder uit dat de baantevredenheid van de cliënten voor een groot gedeelte verklaard wordt door de verbetering van de ontwikkelaspecten. Het valt echter op dat slechts twee van de vijf ontwikkelaspecten de hoge samenhang met de baantevredenheid verklaren. Namelijk, de verbetering van het functioneren, en in mindere mate de relatie met de werkomgeving. Wanneer een 
medewerker/cliënt verzocht wordt om een loopbaanadviseur te consulteren, is dat veelal omdat iemand niet optimaal functioneert. Als het functioneren en de relatie met de werkomgeving door de begeleiding verbeteren, zal de baantevredenheid in de volgende werkkring veelal toenemen.

De andere drie ontwikkelaspecten blijken uit de regressieanalyse geen significante invloed op de baantevredenheid van de cliënt te hebben. Voor het zelfsturend vermogen is dat merkwaardig. Verbruggen en Sels (2008) vinden in hun studie naar het zelfsturend vermogen van cliënten juist een sterke relatie tussen het zelfsturend vermogen en tevredenheid inzake de loopbaan van de cliënt. In het onderhavige onderzoek is juist het verbeterde functioneren van de cliënt de drijvende kracht achter de tevredenheid over de ontwikkeling van de loopbaan. Een vergelijk is echter moeilijk omdat Verbruggen en Sels (2008) andere ontwikkelaspecten uit de onderhavige studie niet hebben meegenomen. Mogelijk is in de onderhavige studie zelfsturing onderdrukt, doordat andere factoren zoals het functioneren en in mindere mate relatie met de werkomgeving meegenomen zijn.

Afgezien van een marginale relatie met de verbetering van de communicatieve vaardigheden van de cliënt, is er geen samenhang gevonden tussen het CMIniveau van de adviseur en de ontwikkelaspecten van de cliënt, noch met diens baantevredenheid, noch met diens tevredenheid over de begeleiding op de korte en middellange termijn. Dit betekent dat een breder CMI-niveau (of juist een smaller CMI-niveau) niet leidt tot meer tevreden cliënten of tot grotere verbeteringen van de ontwikkelaspecten of van de baantevredenheid van de cliënt. Een mogelijke verklaring hiervoor is dat de tevredenheidsscores op alle drie de niveaus al hoog zijn, waardoor een breder of een smaller CMI-niveau geen grotere verbeteringen inzake de ontwikkelaspecten veroorzaakt. 
Ten slotte werd er een beperkt aantal relaties gevonden tussen sommige achtergrondvariabelen van de adviseur en sommige verbeteringen van de vijf ontwikkelaspecten van de cliënt. Zo bleken vrouwelijke adviseurs iets beter in het teweegbrengen van verbeteringen in het zelfbeeld van hun cliënten dan hun mannelijke collegae. Dat geldt ook voor de verbetering van de werkomgeving.

Jongere adviseurs zijn ook beter in het verbeteren van het zelfbeeld van hun cliënten dan hun oudere collegae. Dat jongere adviseurs ook iets meer verbetering teweegbrengen inzake effectief communiceren verbaast niet, gezien de veel grotere eigen vaardigheid inzake effectief communiceren dan de vaardigheid bij oudere collegae. Voor het opleidingsniveau werd geen significante relatie gevonden met de vijf ontwikkelaspecten van de cliënt. Daartoe is ook weinig reden. Waarom zou een wo-opgeleide adviseur (niet specifiek in loopbaanadvisering, zoals in deze steekproef het geval was) meer verbetering in de ontwikkelaspecten kunnen aanbrengen dan een hbo-opgeleide adviseur.

Wel zou een wo-opgeleide adviseur mogelijk sneller effect kunnen bereiken met de vijf ontwikkelaspecten dan de hbo-opgeleide collegae. Daar doet het onderzoek echter geen uitspraak over. Ook voor specifieke werkervaring van de adviseur is er geen significante verbetering gevonden met de vijf ontwikkelaspecten van de cliënt. Verwacht mag worden dat een adviseur met meer specifieke werkervaring meer verbetering teweeg kan brengen in de vijf ontwikkelaspecten dan adviseurs met minder specifieke werkervaring. De bevinding is echter niet in overeenstemming met die verwachting. De auteur van dit proefschrift heeft ook hier geen goede verklaring voor. Nader onderzoek is dan ook nodig. 


\subsubsection{Beperkingen}

Beperkingen in een onderzoek zijn er altijd. Het is belangrijk deze te herkennen, onder meer als opstap naar vervolgonderzoek.

Ontbreken van een controlegroep: de belangrijkste beperking van dit onderzoek zit in het feit dat er geen controlegroep is. Bij praktijk gestuurd veldonderzoek in het kader van de dienstverlening, zoals in het geval van loopbaanadvisering, is dat vaak ook erg moeilijk. Desalniettemin geeft het onderzoek via 'the Theory of Change' een waardevolle indicatie over de effecten van loopbaanbegeleiding.

Zelfrapportage: aan de adviseurs, de cliënten en de opdrachtgevers werd gevraagd of door de begeleiding bepaalde ontwikkelaspecten verbeterd waren. De antwoorden hierop zijn vanzelfsprekend subjectief en bij de adviseurs en opdrachtgevers ${ }^{11}$ zelfs een perceptie van het effect van wat de cliënt vindt. Maar door de enquête niet alleen te richten aan de cliënten, maar ook aan de opdrachtgevers en adviseurs, neemt de betrouwbaarheid van de verkregen informatie toe.

Selectieve respons en uitval: aan de te certificeren adviseurs werd gevraagd om in het kader van de toetsing vijf tevredenheidsverklaringen van cliënten en/of opdrachtgevers te verzamelen. Hierdoor zou het kunnen zijn dat de adviseurs bij hun keuze de meest tevreden vijf cliënten en/of opdrachtgevers hebben uitgenodigd. Waarschijnlijk valt dit mee, omdat de adviseurs door CMI beperkt worden in de keuze van de vijf cliënten en of opdrachtgevers, doordat alleen cliënten en opdrachtgevers worden gevraagd, die minimaal een jaar eerder een passende baan of bestemming hebben gevonden. Door deze beperking kon de adviseur maar uit een beperkt aantal cliënten en opdrachtgevers kiezen, mede gezien het feit dat

\footnotetext{
${ }^{11}$ De opdrachtgevers kregen tevens de vraag te beantwoorden, wat zij zelf vonden van de begeleiding van de adviseur. Die vraag betreft dus geen perceptie.
} 
cliënten bijvoorbeeld door verhuizing, na het vinden van een nieuwe passende baan, niet meer traceerbaar waren. Daardoor blijft het risico om bewust gunstig gezinde respondenten uit te nodigen, beperkt.

In veldonderzoek moet men daarnaast ook altijd met selectieve non-respons (uitval) rekening houden. In het onderhavige geval kan het niet deelnemen aan de enquête verschillende redenen hebben. Een cliënt kan bijvoorbeeld geen klik hebben gehad met de adviseur, waardoor de cliënt besluit af te zien van deelname aan het onderzoek. Dit kan tot hogere tevredenheidscijfers geleid hebben. Het is echter ook mogelijk dat cliënten of opdrachtgevers de enquête juist wel hebben ingevuld omdat ze kritiek hebben op de adviseur, wat weer tot ongunstiger resultaten geleid kan hebben. Door een grote frequentie van het aantal respondenten aan de onderzochte enquêtes, zoals in het onderhavige onderzoek het geval is, zullen mogelijk de positieve en negatieve aspecten tegen elkaar zijn weggevallen.

Verbetering van ontwikkelaspecten: als gevraagd wordt naar de mate van de verbetering van een bepaalde variabele volgens de respondent (hier: ontwikkelaspect cliënt) geeft dat immer een subjectief beeld. De cliënt, waar het in dit proefschrift om gaat, heeft doorgaans ook geen goed referentiekader. Bovendien wordt de subjectiviteit vergroot als de verbetering van de ontwikkelaspecten niet gebeurt op basis van een rechtstreekse meting van de variabele en het verschil tussen twee waarnemingen daarvan, die ook niet op twee verschillende tijdstippen gemeten worden en slechts één vraag omvat. Aangezien alle vijf verbeteringen in de ontwikkelaspecten slechts met één vraag, en bovendien alleen op T2, gemeten werden, neemt het subjectieve element van de meting toe, waardoor de betrouwbaarheid van de meting geringer wordt. Ook in dit geval is de grootte van de steekproef belangrijk voor de mate van betrouwbaarheid. 
Betrouwbaarheid: Alle vragen van de 225 enquêtes die door de loopbaanadviseurs werden ingevuld, waren mogelijk op basis van een verschillende interpretatie van de gestelde vragen beantwoord. Per onderwerp werd ook maar één vraag gesteld, waardoor er ook per vraag vele interpretaties mogelijk waren. Hierdoor kan er ruis ontstaan in de beantwoording van de gestelde vragen. Dit geldt ook voor de 225 enquêtes die aan de cliënten en aan de opdrachtgevers werden voorgelegd. De betrouwbaarheid neemt als gevolg hiervan ook af, al is de omvang van de enquête redelijk groot.

De interne validiteit is, evenals bij veel ander praktijkgericht onderzoek, laag. Alle loopbaanadviseurs, maar ook alle cliënten en opdrachtgevers, die de enquête invulden, deden dat op hun eigen wijze, alsook op hun eigen moment en eigen niveau.

De externe validiteit is bij praktijkgericht veldonderzoek hoog. Echter, de groep te certificeren loopbaanadviseurs zou als gevolg van de certificering kunnen worden aangemerkt als de uitgelezen groep van het vakgebied, waardoor de resultaten van dit onderzoek mogelijk niet te generaliseren zouden zijn naar de gehele populatie loopbaanadviseurs. In het onderhavige proefschrift is echter uitgegaan van vakbekwaamheid. Zonder vakbekwaam te zijn is het niet mogelijk om het vak professioneel uit te voeren en is het derhalve voor de gehele vakgroep niet mogelijk om zich te ontwikkelen naar een professie. Door essentiële thema's van het vakgebied te onderzoeken, werd de mate van kwaliteit gemeten om daarmee het vakgebied als geheel te beoordelen. Basis daarvoor was in alle gevallen de eis dat alle adviseurs vakbekwaamheid hadden aangetoond. Daarmee is het onderzoek zeker niet te generaliseren, maar voldoet het onderzoek wel aan de voorwaarde om de ontwikkeling naar een professie te onderzoeken. 
Aanbevelingen

Lange-termijneffecten: de hoge mate van tevredenheid met de begeleiding van de cliënt op korte en middellange termijn alsmede de stabiliteit daarvan, was reeds lang een vermoeden, maar is door het onderhavig onderzoek voor het eerst vastgesteld. De aanbeveling is dan ook om via de CMI-certificeringsdossiers verder onderzoek te entameren naar de lange-termijneffecten van loopbaanbegeleiding, die het onderzoek naar de huidige vijf ontwikkelaspecten kunnen aanvullen. Daarbij zijn de dossiers van CMI belangrijk materiaal voor praktijkgericht veldonderzoek. De aanbeveling is dan ook om met CMI het dossier voor certificering, alsook het dossier voor re-certificering, zodanig in te richten, dat korte-, middellange- en langetermijneffecten gemakkelijk te onderzoeken zijn. Voor de lange termijn zou de tweede re-certificering zes à acht jaar na de initiële certificering goed passen. Doordat de veelheid en de verscheidenheid van casusvoorbeelden op het gebied van loopbaanadvisering zo uniek is, kan onderzoek naar de ontwikkeling van het vakgebied met behulp van CMI-certificering ook internationaal bijzonder helpen het vakgebied te ontwikkelen in de richting van een professie. Nader onderzoek, met name naar de stabiliteit van de gevonden effecten op lange termijn, wordt dus sterk aanbevolen.

Communicatieve vaardigheden: het onderhavige onderzoek toont duidelijk aan dat het ontwikkelingsaspect verbetering van de communicatieve vaardigheden het minst goed scoort. Aangezien het leven nu eenmaal voor een belangrijk deel bestaat uit communicatie met de ander, zijn goede communicatieve vaardigheden in het proces van het vinden van een passende werkkring essentieel. Nader onderzoek inzake de vraag op welke wijze deze vaardigheden verder geactiveerd kunnen worden is derhalve belangrijk. Het onderzoek kan bijdragen aan een sterke verbetering van de kwaliteit van de uitvoering van het vak. Daarnaast zullen 
adviseurs zelf ook meer aandacht aan de communicatieve vaardigheden moeten geven. Het is daarom voor loopbaanadviseurs zelf belangrijk om de training van hun cliënten in communicatieve vaardigheden ter hand te nemen. Waarschijnlijk is het dan noodzakelijk dat de loopbaanadviseur eerst ook zelf getraind wordt om de training van de cliënten goed te kunnen geven. Train de trainer is dus het devies.

Wijze van begeleiding: dit hoofdstuk van het proefschrift beperkte zich tot het effect van de begeleiding voor de cliënt en toonde aan hoe groot het effect van de begeleiding is. De wijze van begeleiding is daarbij niet specifiek onderzocht. Daarbij gaat het meer om vragen als: hoe dient de cliënt begeleid te worden en hoe kunnen door coaching veranderingen teweeggebracht worden? De keuzes die adviseurs daarbij maken voor wat betreft de focus van de begeleiding zouden nieuwe inzichten kunnen opleveren. Zo blijkt dat de tevredenheid van de cliënt met de begeleiding sterk samenhangt met de verbetering van het zelfbeeld. Mogelijk vindt de adviseur de verbetering van het zelfbeeld het belangrijkste aspect van de begeleiding, mede omdat een goed zelfbeeld volgens Kidd et al. (2003) ook zelfinzicht geeft. Dit kan vervolgens leiden tot meer zelfvertrouwen van de cliënt. Maar daarmee is de vraag 'op welke wijze' de adviseur de verbetering van het zelfbeeld op de meest efficiënte manier zou kunnen verbeteren nog niet gesteld, laat staan onderzocht. Nader onderzoek omtrent de vraag hoe verbeteringen het beste zouden kunnen worden verkregen, wordt dan ook sterk aangeraden.

Gecertificeerde versus niet-gecertificeerde adviseurs: Voor verder onderzoek zou het ook interessant kunnen zijn om ook een groep adviseurs die niet gecertificeerd is naast de huidige groep te plaatsen. Op deze manier zou een controlegroep kunnen worden gecreëerd, waardoor tevens ook bewust toegewerkt zou kunnen worden naar twee of zelfs drie meetmomenten. Onderzoek hiernaar in samenwerking met CMI wordt aanbevolen. 
Specifieke werkervaring: voor specifieke werkervaring van de adviseur is geen significante relatie gevonden met de verbetering van de vijf ontwikkelaspecten van de cliënt. Verwacht mag worden dat een adviseur met meer specifieke werkervaring meer verbetering teweeg kan brengen in de vijf ontwikkelaspecten dan adviseurs met minder specifieke werkervaring. Het resultaat van het onderzoek is echter niet in overeenstemming met die verwachting. De auteur van dit proefschrift heeft hier geen goede verklaring voor. Nader onderzoek is dan ook nodig.

Functioneren: De gevonden sterke verbetering van het functioneren van de cliënten als gevolg van de begeleiding in de perceptie van de opdrachtgever, dient door goede marketing onder de aandacht van opdrachtgevers te worden gebracht, om hen ervan te overtuigen hoe waardevol loopbaanadvisering is om het functioneren van hun personeel te verbeteren. Daarbij gaat het voor de organisaties natuurlijk meer om loopbaancoaching en loopbaanbegeleiding in de organisatie, dan om outplacement. Vooral door loopbaancoaching zullen personeelsleden beter gaan functioneren, maar terzelfdertijd ook beter gaan communiceren en beter met elkaar zullen leren omgaan in de werkomgeving.

Door de begeleiding van de cliënt verbeteren in de perceptie van de opdrachtgever alle drie de ontwikkelaspecten in sterke mate. Voor personeelsleden die, na gecoacht te zijn geweest in hun loopbaan, vervolgens hun dienstverband weer voortzetten, zal de begeleiding niet alleen in de perceptie van de opdrachtgever, maar ook in werkelijkheid een verbetering te zien geven in zowel het functioneren, als in het communiceren, als in de omgang met de werkomgeving. Welke werkgever zou daar niet voor tekenen! 


\section{Bijlage 7A}

Resumé van de NPS 'motivaties' (de tekstuele toelichtingen op de scores) van 13 hoog scorende cliënten en van 9 opdrachtgevers inzake tevredenheidsverklaringen.

\begin{tabular}{|c|c|c|c|}
\hline $\begin{array}{l}\text { Cliënt / } \\
\text { Opdr. }\end{array}$ & Niveau & Score & Motivatie \\
\hline $\mathrm{Cl}$ & $\mathrm{C}$ & 9 & Raadt adviseur aan bij anderen; laat cliënt focussen \\
\hline $\mathrm{Cl}$ & B & 9 & Laat regie bij cliënt; kan directief zijn; ontwikkelgericht \\
\hline $\mathrm{Cl}$ & B & 9 & Maakt bewust van verborgen idealen en kennis + nieuwe baan! \\
\hline $\mathrm{Cl}$ & B & $10+$ & Ontzettend tevreden; derhalve $10+$ \\
\hline $\mathrm{Cl}$ & B & 8.5 & Erg waardevol voor loopbaan- en persoonlijke ontwikkeling \\
\hline $\mathrm{Cl}$ & B & 9 & Bijdrage doorslaggevend voor het succes; humor \\
\hline $\mathrm{Cl}$ & C & 10 & Beloofd is beloofd; toegankelijk; betrokken; luistert goed \\
\hline $\mathrm{Cl}$ & B & 10 & Balans luisteren sturen; maatwerk; betrokken; professioneel \\
\hline $\mathrm{Cl}$ & B & 9 & Goede studiekeuze begeleiding en persoonlijke ontwikkeling \\
\hline $\mathrm{Cl}$ & $\mathrm{C}$ & 9 & Verbetering zelfbeeld en zelfvertrouwen \\
\hline $\mathrm{Cl}$ & B & 10 & Kan op meerdere niveaus contact maken; raakt je als mens \\
\hline $\mathrm{Cl}$ & C & 10 & Luistert; begripvol; empathisch; bewaakt grenzen; duidelijk \\
\hline $\mathrm{Cl}$ & B & 9 & Luistert; analyseert goed; snelle interventies; zet eigen netwerk in \\
\hline Op & C & 9 & Goed in conflicthantering; geweldige coach bij nieuwe start \\
\hline Op & $\mathrm{C}$ & 9.5 & Waardevolle sparing partner; inhoudelijk en in de markt \\
\hline Op & C & 9 & Stimuleert; motiveert; inspireert; geeft structuur \\
\hline Op & C & 10 & Heeft groot inlevingsvermogen; verbetert zelfbeeld; integer \\
\hline Op & B & 9 & Hoog slagingspercentage; zet mensen in beweging; confronteert \\
\hline Op & C & 9 & Verantwoordelijkheid cliënt voorop; oplossingsgericht \\
\hline Op & B & 9 & Raakt mensen; spiegelt; faciliteert; heeft spirituele bagage \\
\hline Op & C & 10 & Denkt mee; initieert; luistert; open; overweegt; integer; maatwerk \\
\hline Op & B & 9 & Hoog slagingspercentage; zet mensen in beweging; confronteert \\
\hline
\end{tabular}

Noot. $M=9,3$ voor cliënten en opdrachtgevers tezamen. 



\section{HOOFDSTUK 8}

\section{ALGEMENE DISCUSSIE EN CONCLUSIES}

In dit hoofdstuk zullen de bevindingen toegelicht worden inzake de vraag wat de kwaliteit van loopbaanadvisering is aan de hand van vier verschillende onderzoeksthema's, te weten: ethiek, specifieke competenties van de loopbaanadviseur, arbeidsmarktbegeleiding en de effecten van de begeleiding. De kwaliteit van het vakgebied is naar weten van de auteur van dit proefschrift nog nimmer in z'n geheel onderzocht.

Gezien de korte ontstaansgeschiedenis van het vakgebied werd voor aanvang van het onderzoek al wel verwacht dat het vakgebied zich zeker nog niet tot een professie zou hebben ontwikkeld. Het onderzoek richtte zich daarom vooral op de vraag in welke mate loopbaanadviseurs kwaliteit bieden. Dat inzicht is belangrijk, omdat het vakgebied loopbaanadvisering, evenals alle bestaande professies, vitale maatschappelijke kenmerken draagt. Bij loopbaanadvisering is dit door mensen in werknood, maar ook bij het zoeken naar een nieuwe baan elders, bij te staan om hen uit een meestal benarde positie te helpen. Vooral ook om cliënten, na een hevige gebeurtenis zoals baanverlies, die grote impact heeft, op een goede manier door het proces te loodsen en te helpen een nieuwe passende baan te verwerven, om zodoende nieuwe kansen te creëren. In dit verband wordt weleens beweerd dat het verlies van een werkkring, na het verlies van de levenspartner, de grootste stressfactor van iemands leven is.

Het proefschrift wil door een ruime keuze van te behandelen thema's de breedte van het vakgebied aangeven. Zo worden belangrijke deelgebieden als ethiek, maar ook specifieke competenties en arbeidsmarktbegeleiding onderzocht op hun kwalitatieve bijdrage aan een professie in wording. Ook het effect van de 
begeleiding wordt aan de hand van drie relevante thema's onderzocht, te weten: de tevredenheid van de cliënten over het begeleidingsproces, de tevredenheid van de cliënt inzake de nieuwe veelal passende baan en de verbetering van vijf essentiële ontwikkelaspecten, te weten: het zelfbeeld, de relatie met de werkomgeving, het functioneren, de communicatieve vaardigheden en het zelfsturend vermogen. Dat loopbaanadvisering zich na veertig jaar nog niet volledig tot een professie heeft ontwikkeld was voorspelbaar. Het ontwikkelproces naar een professie heeft nu eenmaal tijd nodig om de maatschappelijke betekenis van het vakgebied aan het grote publiek duidelijk te maken.

De vraag die derhalve gesteld dient te worden is in welke mate het proces om een professie te worden reeds heeft plaatsgevonden, en welke stappen er in het kader van kwaliteit genomen dienen te worden om loopbaanadvisering op den duur als een professie te mogen typeren. Daarvoor zijn de vier onderzoekhoofdstukken van dit proefschrift voor de lezer een gemakkelijk te volgen leidraad.

\section{Samenvatting van de belangrijkste bevindingen}

Voorafgaande aan de vier hoofdstukken waarin verslag wordt gedaan van het empirisch onderzoek, wordt eerst in Hoofdstuk 2 een historische schets gegeven van de ontwikkeling van het vakgebied in de afgelopen veertig jaar.

Hoofdstuk 3 gaat in op het begrip professie, waarbij op kleine schaal onderzocht wordt in welke mate een aantal loopbaanexperts vinden dat loopbaanbegeleiding zich reeds ontwikkeld heeft op weg naar een professie. Er wordt tevens beschreven wat er in de wetenschappelijke literatuur onder een professie verstaan wordt. In de literatuur werd gevonden dat een professie moeilijk te definiëren valt, vanwege de vele verschillende aspecten van de vakgebieden die onder het verzamelbegrip professie vallen. Burrage et al. (1990), bijvoorbeeld, vinden het 
daarom moeilijk om een professie te definiëren. Verschillende auteurs zijn ertoe overgegaan om een professie te beschrijven aan de hand van een aantal relevante criteria. Deze criteria werden onder meer opgesteld door Greenwood (1957) en Maas (1999), die ieder acht criteria voor een professie opstelden. Greenwood vanuit de zogenaamde conceptbenadering en Maas vanuit de zogenaamde procesbenadering.

Om vervolgens te kunnen onderzoeken in hoeverre loopbaanadvisering zich tot een professie ontwikkeld heeft, werd loopbaanbegeleiding vergeleken met acht beroepsgroepen die allen reeds een professie genoemd worden. Aan drie experts op het terrein van de loopbaanadvisering en aan acht vertegenwoordigers van beroepsgroepen die doorgaans een professie genoemd worden, werden de criteria van Greenwood en Maas voorgelegd ter beoordeling, ieder voor hun eigen beroepsgroep. Loopbaanadvisering behaalde een voldoende score (>3,0 op een vijfpuntsschaal), terwijl de acht beroepsgroepen die een professie genoemd worden als goed ( $>$ 4,0 op een vijfpuntsschaal) beoordeeld werden. Uit het onderzoek bleek dat loopbaanadvisering door een voldoende beoordeling op weg is naar een professie, maar op verschillende punten nog verder ontwikkeld moet worden om van een professie te kunnen spreken.

Maatschappelijke steun en erkenning en wetenschappelijke steun zijn de twee belangrijkste criteria waarop het vakgebied zich verder zou moeten ontwikkelen. Daarnaast is legitimatie door de overheid het derde belangrijke criterium voor de ontwikkeling naar een professie. Dit criterium wordt door de overheid reeds gedeeltelijk toegepast. Aan alle eigen loopbaanadviseurs van de overheid wordt CMI-certificering aangeboden, waardoor de vakbekwaamheid van vele loopbaanadviseurs in overheidsdienst reeds is aangetoond. De overheid geeft hierdoor een belangrijk signaal af, namelijk dat het vakgebied door de overheid zelf belangrijk gevonden wordt. 
Hoofdstuk 4 is het eerste empirische onderzoekhoofdstuk. In dit hoofdstuk wordt dieper ingegaan op de kwaliteit van ethiek en ethisch handelen voor het vakgebied. Zo wordt aangegeven dat een beroepscode voor ethisch handelen voor de ontwikkeling en de kwaliteit van het vakgebied erg belangrijk is om de eenheid van het vak te waarborgen. Zonder overeenstemming over een code voor het beroep hoe ethisch te handelen, is de uitoefening van het vakgebied nauwelijks mogelijk.

Het onderzoek naar ethiek werd uitgevoerd aan de hand van 170 casusvoorbeelden uit bestaande CMI-dossiers van kandidaten voor certificering tot Register Loopbaanprofessional (RL). In het kader van certificering verzoekt CMI de kandidaten een voorbeeld te geven van een ethisch dilemma dat zij in het verleden zijn tegengekomen tijdens het begeleiden van een cliënt, met de vraag hoe zij hiermee zijn omgegaan. Ten behoeve van het onderhavige onderzoek werden de casusvoorbeelden vervolgens door een aantal experts beoordeeld op de kwaliteit van ethisch handelen.

Dit werd gedaan door, naar analogie met Kohlberg (1957), elk casusvoorbeeld in één van vijf opvolgende ontwikkelstadia voor ethisch handelen te plaatsen. Op basis hiervan werd duidelijk dat de kwaliteit van ethisch handelen voor loopbaanadvisering geen gemakkelijk thema blijkt te zijn. Slechts minder dan de helft van de loopbaanadviseurs bleek een correct voorbeeld van een ethisch dilemma te kunnen beschrijven. Hoewel ervan uitgegaan mag worden dat de loopbaanadviseurs in deze steekproef zich door de certificering mogen rekenen tot een uitgelezen groep vakgenoten, die hun vakbekwaamheid hebben aangetoond, zou het kunnen zijn dat sommige loopbaanadviseurs door hun relatief korte specifieke werkervaring in het vakgebied, een ethisch dilemma niet of onvoldoende onderkennen, waardoor er gemiddeld relatief laag gescoord wordt. 
Voorts bleek er een verschil in ethisch handelen te bestaan tussen de drie CMIniveaus. Daaruit blijkt dat adviseurs die werkzaam zijn op een breder CMI-niveau casusvoorbeelden van ethische dillema's beschreven van hogere kwaliteit dan adviseurs werkzaam op een smaller niveau. Tevens werd gevonden dat meer jaren specifieke werkervaring leidt tot betere herkenning van het ethische dilemma. Desondanks werd duidelijk dat loopbaanadviseurs over het algemeen het ethische dilemma nog niet voldoende onderkennen.

In Hoofdstuk 5 werd onderzocht in hoeverre de te certificeren loopbaanadviseurs vijf specifieke competenties, te weten: inlevingsvermogen, communicatieve vaardigheden, reflectie, advisering en coaching, ontwikkeld hebben. Twintig experts beoordeelden 500 casusvoorbeelden uit 100 bestaande CMI-dossiers op de mate waarin adviseurs blijk gaven de vijf competenties ontwikkeld te hebben. Gevonden werd dat alle vijf specifieke competenties met ruim voldoende, dus tussen 3 en 5 op een vijfpuntsschaal, ontwikkeld waren.

Ook werd aangetoond dat er verschillen bestonden tussen de drie CMIniveaus in de mate waarin adviseurs de vijf competenties hadden ontwikkeld. Ten eerste werd gevonden dat, zoals verwacht werd, adviseurs op een breder niveau de competenties reflecteren en adviseren gemiddeld beter hadden ontwikkeld dan adviseurs op een smaller niveau, zij het niet significant.

Ten tweede bleek dat adviseurs op een smaller CMI-niveau twee van de vijf competenties - inlevingsvermogen en coachen - significant beter hadden ontwikkeld dan adviseurs die werkzaam zijn op een breder niveau. Dit is opmerkelijk; verwacht zou mogen worden dat een adviseur met meer ervaring in loopbaanadvisering meer inlevingsvermogen zou hebben dan een adviseur met minder werkervaring. Het is mogelijk dat op het smallere niveau de adviseur meer gefocust is op de cliënt dan de adviseur op het bredere niveau, die meer gefocust is op beleid en op het 
verkrijgen van werk door de cliënt. Daarnaast werd gevonden dat er over het algemeen slechts een beperkte samenhang bestaat tussen de vijf specifieke competenties van de loopbaanadviseur die door CMI werden benoemd. De auteur van dit proefschrift stelt zich daardoor de vraag of andere competenties meer gezamenlijke impact zouden hebben door een betere samenhang te creëren.

In Hoofdstuk 6 werd onderzoek gedaan naar de kwaliteit van de begeleiding van de cliënt naar de arbeidsmarkt. Arbeidsmarktbegeleiding is een essentieel onderdeel van loopbaanbegeleiding. Het is het dynamische proces om cliënten door de adviseur van A naar B te begeleiden vanuit de bestaande organisatie, veelal naar een andere organisatie in de arbeidsmarkt. Ook in dit hoofdstuk werd gewerkt met casusvoorbeelden uit bestaande CMI-dossiers. Eerst werden op basis van kwalitatief onderzoek door de auteur van dit proefschrift categorieën ontwikkeld op basis van the Grounded Theory (GT) voor alle arbeidsmarktaspecten die in de onderzochte 150 casusvoorbeelden aan bod kwamen, uitmondend in negen categorieën.

Vervolgens plaatsten zeven experts de casusvoorbeelden in de volgens hen best passende categorieën. Het onderzoek richtte zich in eerste instantie op wat de adviseurs beschouwden als de meest voorkomende aspecten van de arbeidsmarktbegeleiding. De drie meest voorkomende aspecten van arbeidsmarktbegeleiding bleken te zijn: 1) gebruikmaken van netwerken en sociale media; 2) inzetten van regio- en sectorkennis; 3) gebruikmaken van de verandering in vraag en aanbod op de arbeidsmarkt. Deze drie categorieën omvatten tezamen meer dan de helft van alle onderzochte casusvoorbeelden.

Voorts werden de voorbeelden waarover voldoende consensus bestond over de categorie waarin de casusvoorbeelden door de zeven experts geplaatst waren, door dezelfde experts op kwaliteit van arbeidsmarktbegeleiding beoordeeld. Het 
resultaat hiervan was dat bij slechts iets meer dan de helft van deze casusvoorbeelden de kwaliteit met een voldoende werd beoordeeld.

Gezien de waarderingsgrondslag voor kwaliteit van dit proefschrift is gesteld dat voor een voldoende minimaal 3 op een schaal van 1 - 5 behaald moest worden. Daarmee beschikt de loopbaanadviseur blijkbaar gemiddeld nog over te weinig kwaliteit om de cliënt adequaat te begeleiden bij het betreden van de arbeidsmarkt. Voor de auteur van dit proefschrift was dit een tegenvaller. Uit de praktijk van alledag constateerde hij weliswaar al weinig aandacht voor arbeidsmarktbegeleiding, maar zijn verwachting inzake de kwaliteit van de begeleiding waren hoger gespannen. Zijn constatering werd hierdoor alleen maar bevestigd.

Voorts bleken er verschillen te bestaan tussen de drie CMI-niveaus in de mate van geleverde kwaliteit van de arbeidsmarktbegeleiding. Gevonden werd dat de begeleiding van cliënten naar de arbeidsmarkt door loopbaanadviseurs op een breder CMI-niveau kwalitatief beter is dan die van adviseurs op een smaller CMIniveau. Ook bleek dat de arbeidsmarktbegeleiding door vrouwelijke loopbaanadviseurs gemiddeld iets beter is dan die van mannelijke adviseurs en dat de arbeidsmarktbegeleiding door loopbaanadviseurs met een wo-opleiding gemiddeld iets beter is dan die van adviseurs met een hbo-opleiding. In dit onderzoek werd echter geen relatie gevonden tussen de kwaliteit van de arbeidsmarktbegeleiding en de specifieke werkervaring van de loopbaanadviseur.

In Hoofdstuk 7 werd het effect van de begeleiding onderzocht vanuit drie bronnen: de loopbaanadviseur, de cliënt en de opdrachtgever. Naast het onderzoek naar de vijf ontwikkelaspecten van de cliënt stonden diens tevredenheid met de loopbaanbegeleiding als ook diens tevredenheid met de nieuwe baan centraal. Gevonden werd dat de gemiddelde baantevredenheid van de cliënten drieënhalf jaar na de begeleiding nog immer bijzonder hoog was. 
Daarnaast bleek de tevredenheid van de cliënt met de begeleiding op zowel de korte termijn als op de middellange termijn (gemiddeld drieënhalf jaar later) bijzonder hoog te zijn. Naar weten van de auteur van dit proefschrift is deze hoge en stabiele uitkomst van de tevredenheid van de cliënt en van de opdrachtgever met de begeleiding, zowel op korte als op middellange termijn nog niet eerder aangetoond. Mogelijk is de niet te onderschatten emotionele impact van het baanverlies en het daaropvolgende, veelal heftige, loopbaanbegeleidingsproces zelf een belangrijke verklaring voor deze bevinding.

Ook heeft de begeleiding volgens de cliënten zelf een positieve invloed gehad op deze vijf ontwikkelaspecten van het loopbaanbegeleidingsproces. Van de vijf ontwikkelaspecten zijn de adviseurs van mening dat het zelfbeeld van de cliënten door de begeleiding het meest verbeterd is, gevolgd door de verbetering van het zelfsturend vermogen en het functioneren. De communicatieve vaardigheden worden in de ogen van de adviseurs door de begeleiding het minst verbeterd. Evenals de adviseurs vinden de cliënten het zelfbeeld, alsook het zelfsturend vermogen en het functioneren, als gevolg van de begeleiding zeer sterk verbeterd. Ook de opdrachtgevers blijken zeer tevreden te zijn over de begeleiding van de cliënten door de zelf uitgekozen adviseurs. Zij vinden vooral het functioneren, maar ook de relatie met de werkomgeving en de communicatieve vaardigheden sterk verbeterd. Alle drie de bronnen zijn het dus eens over de sterke verbetering van het functioneren als gevolg van de begeleiding.

In de literatuur wordt nog weinig tot geen aandacht besteed aan het functioneren van de cliënt. Dat is merkwaardig omdat de reden voor de begeleiding veelal gezocht dient te worden bij het minder functioneren van de cliënt in zijn of haar werkkring. De opdrachtgevers noemen de verbetering van het functioneren van de cliënten zelfs de grootste verbetering als gevolg van de begeleiding. 
Opvallend is dat naast het oordeel van de opdrachtgevers over de verbetering van het functioneren van cliënten, ook het verbeteren van de relatie met de werkomgeving van cliënten en van hun communicatieve vaardigheden zeer hoog uitvalt. Voor de relatie van de opdrachtgevers met hun medewerkers/cliënten blijken alle drie de verbeteringen van de ontwikkelaspecten buitengewoon positief te zijn.

De hoge mate van tevredenheid van de cliënt met de nieuwe passende baan en de sterke relatie van de verbetering van het functioneren van de cliënt met diens baantevredenheid zijn wellicht voor het gehele proefschrift de belangrijkste bevindingen. Voor loopbaanadvisering is zowel het verkrijgen van een passende nieuwe baan als de verbetering van het functioneren immers de kern waar het in dit vakgebied om gaat.

\section{Loopbaanadvisering op weg naar een professie?}

In de voorgaande sectie werden de bevindingen van de verschillende empirische hoofdstukken uit dit proefschrift afzonderlijk besproken. Hieronder zullen de verschillen en overeenkomsten tussen deze bevindingen toegelicht worden inzake de vraag in welke mate de kwaliteit van de loopbaanadvisering zich heeft ontwikkeld met betrekking tot de vier verschillende onderzoeksthema's.

De primaire vraag is in welke mate de loopbaanadviseur de genoemde aspecten ontwikkeld heeft in termen van kwaliteit van loopbaanbegeleiding. Tabel 8.1 geeft een overzicht van de gemiddelde kwaliteit van loopbaanbegeleiding, uitgesplitst naar CMI-niveau en achtergrondvariabelen van loopbaanadviseurs, aan de hand van de vier onderzochte loopbaanthema's, te weten: het ethische dilemma, de specifieke competenties van de loopbaanadviseur, de arbeidsmarktbegeleiding en de effecten van de loopbaanbegeleiding. 
Tabel 8.1

Totaaloverzicht van de kwaliteit van de begeleiding door de loopbaanadviseur van de aspecten ethiek, specifieke competenties, arbeidsmarktbegeleiding en effecten van de begeleiding, uitgesplitst naar CMIniveau en achtergrondvariabelen van de adviseur.

\begin{tabular}{|c|c|c|c|c|c|c|}
\hline $\begin{array}{l}\text { Loopbaan- } \\
\text { thema }\end{array}$ & $\begin{array}{l}\text { Overall } \\
\text { kwaliteit }\end{array}$ & $\begin{array}{l}\text { CMI- } \\
\text { niveau }\end{array}$ & Gender & Leeftijd & Opleiding & $\begin{array}{c}\text { Spec. } \\
\text { werk- } \\
\text { ervaring }\end{array}$ \\
\hline $\begin{array}{l}\text { H4: } \\
\text { Ethiek } \\
(N=170)\end{array}$ & $\begin{array}{c}45 \%^{*}: \\
\text { Kwaliteit } \\
\text { onvoldoende }\end{array}$ & $\begin{array}{l}\text { Verschil: } \\
\mathrm{A}<\mathrm{B}<\mathrm{C}\end{array}$ & $\begin{array}{c}\text { Geen } \\
\text { verschil }\end{array}$ & $\begin{array}{l}\text { Geen } \\
\text { relatie }\end{array}$ & $\begin{array}{c}\text { Geen } \\
\text { verschil }\end{array}$ & $\begin{array}{l}\text { Marg. } \\
\text { relatie }\end{array}$ \\
\hline $\begin{array}{l}\mathrm{H} 5: \\
\text { Specifieke } \\
\text { Competen- } \\
\text { ties } \\
(N=100)\end{array}$ & $\begin{array}{c}74 \% * \\
\text { Kwaliteit } \\
\text { voldoende }\end{array}$ & $\begin{array}{c}\text { Geen } \\
\text { verschillen, } \\
\text { behalve } \\
\text { voor } \\
\text { inleving en } \\
\text { coachen: } \\
\mathrm{A}>\mathrm{B}>\mathrm{C}\end{array}$ & $\begin{array}{c}\text { Geen } \\
\text { verschillen, } \\
\text { behalve } \\
\text { voor } \\
\text { inleving } \\
\text { en effect. } \\
\text { commun.: } \\
\mathrm{v}>\mathrm{m}\end{array}$ & $\begin{array}{c}\text { Geen } \\
\text { relaties, } \\
\text { behalve } \\
\text { met effect. } \\
\text { commun.: } \\
\text { negatief }\end{array}$ & $\begin{array}{c}\text { Geen } \\
\text { relaties, } \\
\text { behalve } \\
\text { marg. met } \\
\text { coachen: } \\
\text { hbo > wo }\end{array}$ & $\begin{array}{c}\text { Geen } \\
\text { relaties, } \\
\text { behalve } \\
\text { marg. neg. } \\
\text { met } \\
\text { inleving }\end{array}$ \\
\hline $\begin{array}{l}\text { H6: } \\
\text { Arbeids- } \\
\text { markt- } \\
\text { begeleiding } \\
(N=150)\end{array}$ & $\begin{array}{c}57 \%^{*}: \\
\text { Kwaliteit } \\
\text { onvoldoende }\end{array}$ & $\mathrm{A}<\mathrm{B}, \mathrm{C}$ & $\begin{array}{c}\text { Marg. } \\
\text { verschil: } \\
\text { v > m }\end{array}$ & $\begin{array}{l}\text { Geen } \\
\text { relatie }\end{array}$ & $\begin{array}{c}\text { Marg. } \\
\text { verschil: } \\
\text { wo > hbo }\end{array}$ & $\begin{array}{l}\text { Geen } \\
\text { relatie }\end{array}$ \\
\hline $\begin{array}{l}\text { H7: } \\
\text { Effecten } \\
\text { Begeleiding } \\
(N=225)\end{array}$ & $\begin{array}{l}M=76^{* *}: \\
\text { Kwaliteit } \\
\text { gemiddeld } \\
\text { voldoende }\end{array}$ & $\begin{array}{c}\text { Geen }^{* * *} \\
\text { verschillen, } \\
\text { behalve } \\
\text { voor effect. } \\
\text { commun.: } \\
\text { negatief }\end{array}$ & $\begin{array}{c}\text { Geen } \\
\text { verschillen, } \\
\text { behalve } \\
\text { voor } \\
\text { zelfbeeld } \\
\text { en relatie } \\
\text { werk- } \\
\text { omgeving: } \\
\text { v > m }\end{array}$ & $\begin{array}{l}\text { Geen*** } \\
\text { relaties, } \\
\text { behalve } \\
\text { voor } \\
\text { zelfbeeld } \\
\text { en effect. } \\
\text { commun.: } \\
\text { beide } \\
\text { negatief }\end{array}$ & $\begin{array}{c}\text { Geen }^{* * *} \\
\text { verschillen }\end{array}$ & $\begin{array}{l}\text { Geen*** } \\
\text { relaties }\end{array}$ \\
\hline $\begin{array}{l}\text { Totaal: } \\
(N=161)\end{array}$ & $\begin{array}{c}M=63^{* * * *}: \\
\text { Overall } \\
\text { kwaliteit } \\
\text { voldoende }\end{array}$ & $\begin{array}{l}\text { Hiërarchie } \\
\text { verschilt } \\
\text { per thema }\end{array}$ & $\begin{array}{l}\text { Hiërarchie } \\
\text { verschilt } \\
\text { per thema }\end{array}$ & $\begin{array}{l}\text { Hiërarchie } \\
\text { verschilt } \\
\text { per thema }\end{array}$ & $\begin{array}{c}\text { Hiërarchie } \\
\text { verschilt } \\
\text { per thema }\end{array}$ & $\begin{array}{l}\text { Hiërarchie } \\
\text { verschilt } \\
\text { per thema }\end{array}$ \\
\hline
\end{tabular}

Noten. Marg. = marginaal; Sign = significant; Neg. = negatief; Effect. commun. = effectief

communiceren; $* \%$ percentage aantal correcte voorbeelden; $* *$ gemiddelde van 5

ontwikkelaspecten + baantevredenheid + tevredenheid met begeleiding cliënten, op 100-puntsschaal;

${ }^{* * *}$ alleen verschillen in/relaties met vijf ontwikkelaspecten onderzocht; ${ }^{* * * *}$ gemiddelde van de scores

op alle thema's (waarbij percentages verdisconteerd naar gemiddelden), gemeten op 100-puntsschaal. 


\section{Kwaliteit van de begeleiding}

Inzake ethiek is geconstateerd dat de kwaliteit nog onvoldoende is. Uit het onderhavige onderzoek bleek dat nog onvoldoende herkenning van het ethisch dilemma vastgesteld kon worden. Door meer specifieke werkervaring van de loopbaanadviseur zal de herkenning van het ethisch dilemma gestimuleerd kunnen worden. Inzake de kwaliteit van de vijf specifieke competenties van loopbaanadviseurs werd geconstateerd dat deze gemiddeld als ruim voldoende werd beoordeeld. Inzake de arbeidsmarktbegeleiding bleek dat er slechts voor iets meer dan de helft van de casusvoorbeelden kwaliteit geleverd werd. Dat wil zeggen dat het criterium voor voldoende, namelijk $>3.0$ (op een vijfpuntsschaal) niet gehaald wordt. Dat komt overeen met de verwachting van de auteur van dit proefschrift, die vindt dat de kwaliteit van de arbeidsmarktbegeleiding verbeterd zou moeten worden door meer aandacht aan arbeidsmarktontwikkeling te geven, zowel in de praktijk van de begeleiding, bijvoorbeeld door meer intervisie, als in de opleidingen van de loopbaanadviseurs, bijvoorbeeld door het creëren van meer stageplaatsen.

Inzake de effecten van de begeleiding bleek dat de baantevredenheid van de cliënten, en de tevredenheid van de cliënten met de begeleiding, zelfs drieënhalf jaar na de begeleiding, hoog scoren. Ook de vijf ontwikkelaspecten worden als geheel hoog beoordeeld: alle tezamen scoren hoger dan drie op een vijfpuntsschaal. Maar ook ieder van de vijf ontwikkelaspecten afzonderlijk scoort hoger dan drie op een vijfpuntsschaal.

Resumerend betekent dit voor de kwaliteit op het terrein van alle onderzochte thema's, inclusief de onvoldoende score voor ethiek en de nog niet voldoende score voor arbeidsmarktbegeleiding, dat de kwaliteitsaspecten voor de vier onderzoeksthema's tezamen gemiddeld meer dan drie (>3.0) op een vijfpuntsschaal scoren, hetgeen de auteur van dit proefschrift heeft gekwalificeerd als voldoende. 
Dat is een voorzichtige indicatie dat loopbaanadvisering op weg is om een professie te worden. Voor ethiek werd evenwel geconstateerd dat de score na verloop van tijd aanmerkelijk hoger moet worden. Dat is mogelijk als de loopbaanadviseurs in dit jonge vak meer specifieke werkervaring gaan krijgen, waardoor herkenning van een ethisch dilemma eenvoudiger wordt.

Evenals bij ethiek zal ook de kwaliteit van de arbeidsmarktbegeleiding van de verwachte toename van de academische opleidingen voor loopbaanadvisering profiteren, mede door meer contact tussen de wetenschap en de praktijk. Door de hoge eigen beoordelingen van zowel de adviseur als van de cliënt zelf als van de opdrachtgever inzake de kwaliteit van de effecten van de begeleiding, is de uitkomst dat de totale beoordeling van de vier onderzoekthema's een voldoende (dus > 3.0 op een vijfpuntsschaal) aangeeft.

\section{Verschillen tussen de drie CMI-niveaus}

In deze paragraaf komen de overeenkomsten en verschillen tussen de drie CMI-niveaus per onderzoeksthema aan de orde. De verschillende frequenties $(N)$ van de drie CMI-niveaus zijn per onderzoeksthema in Tabel 8.2 aangegeven. Inzake ethiek blijken er, zoals verwacht, verschillen te bestaan tussen de drie CMIniveaus in de mate waarin ethisch handelen ontwikkeld is. Dat wil zeggen, hoe breder het CMI-niveau, hoe beter het ethisch handelen van de adviseur ontwikkeld is. Voor twee van de vijf specifieke competenties van de adviseur werd er een verschil gevonden tussen de drie CMI-niveaus. Gevonden werd dat de competenties inlevingsvermogen en coachen beter ontwikkeld waren naarmate het CMI-niveau smaller is. Voor inlevingsvermogen strookt dit niet met de verwachting. Hoe breder het niveau is, hoe meer ervaring de adviseurs van dat niveau zouden moeten tonen, waardoor inlevingsvermogen het beste tot $z$ 'n recht zou moeten komen. Voor 
coachen ligt dat anders. Op een smaller niveau wordt coaching als competentie het meest toegepast, waardoor de adviseurs op dat niveau de meeste ervaring opbouwen.

Voor de kwaliteit van de arbeidsmarktbegeleiding wordt geconstateerd dat er een significant verschil bestaat tussen het smalste niveau (A) en het bredere niveau (B). Het breedste niveau (C) scoort kwalitatief het best. Er is evenwel geen verschil geconstateerd tussen het smalste niveau (A) en het breedste niveau (C) alsmede tussen het bredere niveau (B) en het breedste niveau (C). Op zich zou verwacht mogen worden dat er ook een significant verschil geconstateerd zou worden tussen zowel het smalste niveau (A) en het breedste niveau (C) als ook tussen het minder brede niveau (B) en het breedste niveau (C). Een mogelijke verklaring hiervoor dient gezocht te worden in het feit dat de frequenties van respondenten op de niveaus $\mathrm{A}$ en $\mathrm{C}$ betrekkelijk klein zijn ten opzichte van de grotere frequentie van niveau $\mathrm{B}$.

Bij de effecten van de begeleiding blijkt er geen verschil te bestaan tussen het CMI-niveau en de mate van ontwikkeling van de vijf ontwikkelaspecten door de cliënt, met uitzondering van een marginaal verschil in communicatieve vaardigheden. Ook bij de baantevredenheid en de tevredenheid op korte en middellange termijn bleek dat het geen verschil uitmaakt vanuit welk CMI-niveau de adviseur afkomstig is. Het vermoeden is dat dit wordt veroorzaakt door de hoge gemiddelde scores van de verbetering van de vijf ontwikkelaspecten alsmede van de tevredenheid over de begeleiding.

De conclusie is derhalve dat er een duidelijk hiërarchisch verschil bestaat tussen de drie CMI-niveaus in ethisch handelen, waarbij adviseurs die werkzaam zijn op een breder niveau beter weten om te gaan met ethische dilemma's. Tevens werd geconstateerd dat er tussen de drie CMI-niveaus juist een omgekeerde hiërarchie bestaat inzake twee van de specifieke competenties van de adviseur, te 
weten inlevingsvermogen en coachen, terwijl voor reflecteren en adviseren (arbeidsmarktbegeleiding) het breedste niveau gemiddeld het beste beoordeeld wordt. Voor de effecten van de begeleiding is er geen verschil tussen de drie CMIniveaus geconstateerd, met uitzondering van een negatieve relatie met het verbeteren van de communicatieve vaardigheden van de cliënt.

\section{Tabel 8.2}

Overzicht van het aantal respondenten voor de drie CMI-niveaus voor ethiek, specifieke competenties, opleiding en effecten van de begeleiding.

\begin{tabular}{|c|c|c|c|c|}
\hline Onderzoeksthema & $\begin{array}{c}\text { CMI-niveau } \\
\text { A }\end{array}$ & $\begin{array}{c}\text { CMI-niveau } \\
\text { B }\end{array}$ & $\begin{array}{c}\text { CMI-niveau } \\
\text { C }\end{array}$ & Totale $N$ \\
\hline H4: Ethiek & $\begin{array}{c}30 \\
(18 \%)\end{array}$ & $\begin{array}{c}100 \\
(58 \%)\end{array}$ & $\begin{array}{c}40 \\
(24 \%)\end{array}$ & 170 \\
\hline $\begin{array}{l}\text { H5: Specifieke } \\
\text { competenties }\end{array}$ & $\begin{array}{c}29 \\
(29 \%)\end{array}$ & $\begin{array}{c}59 \\
(59 \%)\end{array}$ & $\begin{array}{c}12 \\
(12 \%)\end{array}$ & 100 \\
\hline $\begin{array}{l}\text { H6: Arbeidsmarkt } \\
\text { begeleiding }\end{array}$ & $\begin{array}{c}33 \\
(22 \%)\end{array}$ & $\begin{array}{c}90 \\
(60 \%)\end{array}$ & $\begin{array}{c}27 \\
(18 \%)\end{array}$ & 150 \\
\hline $\begin{array}{l}\text { H7: Effecten van de } \\
\text { begeleiding }\end{array}$ & $\begin{array}{c}26 \\
(16 \%)\end{array}$ & $\begin{array}{c}80 \\
(50 \%)\end{array}$ & $\begin{array}{c}55 \\
(34 \%)\end{array}$ & 161 \\
\hline Totaal gemiddelden & $\begin{array}{l}N=30 \\
(21 \%)\end{array}$ & $\begin{array}{l}N=82 \\
(56 \%)\end{array}$ & $\begin{array}{l}N=34 \\
(23 \%)\end{array}$ & $\begin{array}{l}N=146 \\
(100 \%)\end{array}$ \\
\hline
\end{tabular}




\section{Achtergrondvariabelen}

In deze paragraaf komen de overeenkomsten en verschillen tussen de achtergrondvariabelen van de loopbaanadviseurs voor elk van de vier onderzoeksthema's aan de orde. In Tabel 8.3 wordt een overzicht van de verschillenen relaties voor alle achtergrondvariabelen per onderzoeksthema weergegeven.

Tabel 8.3

Overzicht van achtergrondvariabelen van de loopbaanadviseurs voor de hoofdstukken ethiek, specifieke competenties, arbeidsmarktbegeleiding en effecten van de loopbaanbegeleiding.

\begin{tabular}{|c|c|c|c|c|c|}
\hline $\begin{array}{l}\text { Loopbaan- } \\
\text { thema's }\end{array}$ & $N$ & $\begin{array}{l}\text { Gender } \\
\text { (\% man) }\end{array}$ & $\begin{array}{c}\text { Gemiddelde } \\
\text { leeftijd } \\
\text { in jaren* }\end{array}$ & $\begin{array}{l}\text { Opleiding } \\
\text { (\% wo) }\end{array}$ & $\begin{array}{c}\text { Gemiddelde } \\
\text { Specifieke } \\
\text { werkervaring } \\
\text { in jaren* }\end{array}$ \\
\hline $\begin{array}{l}\text { H4: Ethisch } \\
\text { handelen }\end{array}$ & 170 & $24 \%$ & 51 & $26 \%$ & 11 \\
\hline $\begin{array}{l}\text { H5: Specifieke } \\
\text { competenties }\end{array}$ & 100 & $24 \%$ & 49 & $34 \%$ & 10 \\
\hline $\begin{array}{l}\text { H6: } \\
\text { Arbeidsmarkt } \\
\text { begeleiding }\end{array}$ & 150 & $28 \%$ & 50 & $33 \%$ & 13 \\
\hline $\begin{array}{l}\text { H7: Effecten van } \\
\text { de begeleiding }\end{array}$ & 225 & $33 \%$ & 53 & $44 \%$ & 11 \\
\hline Gem. totaal & 161 & $27 \%$ & 51 & $34 \%$ & 11 \\
\hline
\end{tabular}

Noot. * Per 1-07-2014. 
Gender: ten aanzien van ethiek is er geen verschil tussen mannen en vrouwen in ethisch handelen. Voor de specifieke competenties van de adviseurs blijken mannen en vrouwen marginaal te verschillen in zowel inlevingsvermogen als effectief communiceren. Voor deze twee specifieke competenties blijken vrouwen deze beter ontwikkeld te hebben dan hun mannelijke collegae. Voor de drie andere competenties werd geen verschil gevonden tussen mannelijke en vrouwelijke loopbaanadviseurs. Bij de arbeidsmarktbegeleiding blijkt dat vrouwen ook kwalitatief iets beter begeleiden dan hun mannelijke collegae.

Ook inzake de effecten van de begeleiding werden enkele verschillen gevonden tussen mannelijke en vrouwelijke loopbaanadviseurs. Vrouwen blijken zowel in het zelfbeeld van de cliënt als in diens relatie met de werkomgeving iets meer verbetering tot stand te brengen dan hun mannelijke collegae. De conclusie voor gender is derhalve dat vrouwelijke adviseurs op een aantal onderzoeksthema's (iets) beter scoren dan hun mannelijke collegae, namelijk voor twee van de specifieke competenties alsook voor arbeidsmarktbegeleiding en ook voor twee ontwikkelaspecten van de cliënt, namelijk voor zelfbeeld en voor de relatie met de werkomgeving.

Leeftijd: voor ethiek bleek leeftijd geen relatie te hebben met de mate van het ethisch handelen Voor de vijf specifieke competenties van de adviseur werd er alleen een negatieve samenhang gevonden tussen de leeftijd van de adviseur en diens mate van effectief communiceren. Dat wil zeggen dat hoe jonger de adviseur is, hoe beter hij of zij is in effectief communiceren. Met de andere vier specifieke competenties werd geen samenhang gevonden. Voor de kwaliteit van de arbeidsmarktbegeleiding is er geen samenhang met leeftijd gevonden. Dat wil dus zeggen dat het geen verschil maakt voor de arbeidsmarktbegeleiding hoe oud de adviseur is. Dat verbaast de 
auteur van dit proefschrift enigszins; oudere adviseurs hebben veelal meer ervaring in de arbeidsmarkt, waardoor de begeleiding zou moeten verbeteren.

Bij de effecten van de begeleiding is er wel een significante, zij het negatieve, relatie gevonden tussen leeftijd en één van de vijf ontwikkelaspecten van de cliënt, namelijk het verbeteren van het effectief communiceren door de cliënt. Derhalve zijn de jongere adviseurs kwalitatief beter in het effectief verbeteren van de communicatieve vaardigheden van hun cliënten dan hun oudere collegae. Daarnaast werd gevonden dat de leeftijd van de adviseur positief gerelateerd was aan het verbeteren van het zelfbeeld van de cliënt. Dat wil zeggen dat oudere adviseurs beter verbeteringen in het zelfbeeld van hun cliënten teweeg kunnen brengen, terwijl juist jongere adviseurs beter zijn in de verbeteren van het effectief communiceren van hun cliënten. De conclusie is dat de achtergrondvariabele leeftijd een gevarieerd beeld geeft inzake de verschillende onderzoeksthema's, namelijk: er is voor ethiek geen relatie met ethisch handelen gevonden; voor de specifieke competenties is er eveneens geen samenhang gevonden met de leeftijd, afgezien voor de verbetering in het effectief communiceren van begeleiding van de adviseur; voor de arbeidsmarktbegeleiding maakt de leeftijd geen verschil; bij effecten van de begeleiding is er een negatieve relatie gevonden met het effectief verbeteren van de communicatieve vaardigheden van cliënten en een positieve relatie met de verbetering van het zelfbeeld van cliënten.

Opleiding: Het opleidingsniveau van de adviseur bleek niet samen te hangen met de mate waarin hij of zij ethisch handelt. Dat wil dus zeggen dat wo-adviseurs geen blijk geven van beter ethisch handelen dan hbo-adviseurs. Inzake de specifieke competenties van de adviseur is er alleen een marginale negatieve relatie gevonden tussen opleiding en de competentie coaching: hbo-opgeleide adviseurs blijken de competentie coachen een fractie beter te hebben ontwikkeld dan hun wo-opgeleide 
collegae. Voor arbeidsmarktbegeleiding is het juist andersom: de wo-opgeleide adviseurs scoren op kwaliteit van de arbeidsmarkt-begeleiding een fractie beter dan de adviseurs met een hbo-opleiding. Inzake het effect van de begeleiding is er geen significante relatie tussen opleiding van de adviseur en de mate waarin hij of zij een verbetering teweegbrengt in de verschillende ontwikkelaspecten van hun cliënten. Geconcludeerd kan worden dat er geen eenduidig kwaliteitsverschil is tussen de hbo- en wo-opgeleide loopbaanadviseurs. Mogelijk hangt dit samen met het feit dat in deze steekproef de wo-opgeleide adviseurs (nog) geen vakspecifieke opleiding (namelijk voor loopbaanadvisering) hadden gevolgd, waardoor er mogelijk geen verschil in bijdrage in de verbetering van de ontwikkelaspecten ontstaan is.

Specifieke werkervaring: Met betrekking tot ethiek blijkt de specifieke werkervaring van de adviseur een marginale relatie te hebben met de kwaliteit van diens ethisch handelen. Dat wil zeggen, hoe langer iemand het vak van loopbaanadviseur uitoefent, hoe beter diens ethisch handelen ontwikkeld is. Tussen de ontwikkeling van de specifieke competenties van de loopbaanadviseur en diens specifieke werkervaring is, tegen de verwachting in, geen relatie gevonden, afgezien van een marginale negatieve relatie met inlevingsvermogen. Dit wil zeggen dat een adviseur met minder specifieke werkervaring meer inlevingsvermogen toont dan een adviseur met meer specifieke werkervaring. Voor de kwaliteit van arbeidsmarktbegeleiding is er geen enkele relatie geconstateerd met de specifieke werkervaring. Inzake de effecten van de begeleiding van de cliënt blijkt de specifieke werkervaring ook geen relatie te hebben met de verbetering van de vijf ontwikkelaspecten van de cliënt.

Geconcludeerd kan worden dat er een marginale relatie is tussen specifieke werkervaring en het ethisch handelen alsmede een marginaal negatieve relatie tussen de specifieke werkervaring en de competentie inlevingsvermogen. Maar dat 
er verder geen sprake is van relaties tussen de specifieke werkervaring van de adviseur enerzijds en de onderzoeksthema's anderzijds.

Ten slotte laat Tabel 8.4 voor de drie CMI-niveaus zien hoe de wo-opgeleide adviseurs zich qua aantallen verhouden tot de adviseurs op hbo-niveau, als de vier onderzoekthema's als geheel onderzocht worden. Het relatieve resultaat van Tabel 8.4 geeft aan dat er voor niveau A en niveau B nauwelijks verschillen zijn. Relatief wil zeggen: het quotiënt tussen bijvoorbeeld het totale aantal wo-opgeleide adviseurs van een bepaald onderzoekthema (voor het ethisch dilemma dus 45 wo opgeleiden) gedeeld door het aantal wo-opgeleide adviseurs in niveau A (voor niveau A van het ethisch dilemma dus 5 wo-opgeleiden).

Niveau A laat derhalve zien dat het relatieve resultaat van 20\% zowel voor wo-opgeleide adviseurs geldt als voor hbo-opgeleide adviseurs. Niveau B geeft een relatief resultaat van $56 \%$ voor wo-opgeleide adviseurs en $58 \%$ voor hbo-opgeleide adviseurs. Derhalve is er ook voor niveau B nauwelijks een verschil tussen het aantal respondenten met een hbo- versus een wo-opleiding. De tabel laat echter zien dat er op niveau $\mathrm{C}$ een relatief groot verschil bestaat in het aantal wo-opgeleide adviseurs en het aantal hbo-opgeleide adviseurs. Op niveau $\mathrm{C}$ komen relatief bijna anderhalf keer meer wo-adviseurs voor in de onderzoeksthema's dan hun hbo-collegae, namelijk 27\% ten opzichte van 18\%. Dat wil zeggen dat wo-opgeleide adviseurs anderhalf keer meer kiezen voor het breedste niveau dan de hbo-opgeleide adviseurs. Dat is ook verstandig gezien het beleidsmatige karakter van het C-niveau. Dit versterkt de stelling van de auteur van dit proefschrift, namelijk dat zelfstandig werkende loopbaanadviseurs die, parallel aan andere beroepsgroepen die een professie genoemd worden, op het breedste niveau willen werken een wo-opleiding in loopbaanadvisering zouden moeten voltooien om in het vakgebied op het brede C- niveau te kunnen werken. 
Tabel 8.4

Overzicht van het resultaat hbo- en wo-percentage per CMI-niveau voor de 4 onderzoeksthema's.

\begin{tabular}{|c|c|c|c|c|c|c|c|c|}
\hline $\begin{array}{l}\text { Loopbaan } \\
\text { thema's }\end{array}$ & $\begin{array}{c}\mathrm{N} \\
\text { Totaal }\end{array}$ & $\begin{array}{c}\text { Totaal } \\
\text { CMI- } \\
\text { niveau }\end{array}$ & $\begin{array}{c}\text { wo } \\
\text { totaal }\end{array}$ & $\begin{array}{l}\text { hbo } \\
\text { totaal }\end{array}$ & $\begin{array}{c}\text { wo } \\
\text { aantal }\end{array}$ & $\begin{array}{c}\text { hbo } \\
\text { aantal }\end{array}$ & wo $\%$ & hbo \% \\
\hline \multicolumn{9}{|c|}{ CMI-niveau A } \\
\hline $\begin{array}{l}\text { H4: Ethisch } \\
\text { dilemma }\end{array}$ & 170 & 30 & 45 & 125 & 5 & 25 & $11 \%$ & $20 \%$ \\
\hline $\begin{array}{l}\text { H5: Spec. } \\
\text { Comp. }\end{array}$ & 100 & 29 & 33 & 67 & 9 & 20 & $27 \%$ & $30 \%$ \\
\hline $\begin{array}{l}\text { H6: Arb. } \\
\text { Markt }\end{array}$ & 150 & 33 & 47 & 103 & 13 & 20 & $28 \%$ & $12 \%$ \\
\hline H7: Effect & 160 & 26 & 70 & 90 & 9 & 17 & $13 \%$ & $19 \%$ \\
\hline Totaal gem. & 145 & 30 & 49 & 96 & 9 & 21 & $20 \%$ & $20 \%$ \\
\hline \multicolumn{9}{|c|}{ CMI-niveau B } \\
\hline $\begin{array}{l}\text { H4: Ethiek } \\
\text { dilemma }\end{array}$ & 170 & 100 & 45 & 125 & 28 & 72 & $62 \%$ & $58 \%$ \\
\hline $\begin{array}{l}\text { H5: Spec. } \\
\text { Comp. }\end{array}$ & 100 & 59 & 33 & 67 & 18 & 41 & $56 \%$ & $61 \%$ \\
\hline $\begin{array}{l}\text { H6: Arb. } \\
\text { Markt }\end{array}$ & 150 & 90 & 47 & 103 & 29 & 61 & $62 \%$ & $59 \%$ \\
\hline H7: Effect & 160 & 80 & 70 & 90 & 31 & 49 & $44 \%$ & $54 \%$ \\
\hline Totaal gem. & 145 & 82 & 49 & 96 & 27 & 56 & $56 \%$ & $58 \%$ \\
\hline \multicolumn{9}{|c|}{ CMI-niveau C } \\
\hline $\begin{array}{l}\text { H4: Ethiek } \\
\text { dilemma }\end{array}$ & 170 & 40 & 45 & 125 & 12 & 28 & $27 \%$ & $22 \%$ \\
\hline $\begin{array}{l}\text { H5: Spec. } \\
\text { Comp. }\end{array}$ & 100 & 12 & 33 & 67 & 5 & 7 & $15 \%$ & $10 \%$ \\
\hline $\begin{array}{l}\text { H6: Arb. } \\
\text { Markt }\end{array}$ & 150 & 27 & 47 & 103 & 10 & 17 & $21 \%$ & $17 \%$ \\
\hline H7: Effect & 160 & 54 & 70 & 90 & 30 & 24 & $43 \%$ & $26 \%$ \\
\hline Totaal gem. & 145 & 33 & 49 & 96 & 14 & 19 & $27 \%$ & $18 \%$ \\
\hline
\end{tabular}




\section{Beperkingen}

Zoals elk onderzoek kennen alle vijf onderzoeken van dit proefschrift enkele beperkingen. Hieronder zullen de belangrijkste beperkingen die voor deze onderzoeken gelden kort besproken worden.

Zelfrapportage: De eerste belangrijke beperking betreft het feit dat de data van alle vijf onderzoeken door zelfrapportage zijn verkregen. Het subjectieve element speelt bij zelfrapportage veelal een belangrijke rol, waardoor de resultaten minder betrouwbaar kunnen zijn.

In Hoofdstuk 3 inzake de professie werd aan slechts drie experts gevraagd voor loopbaanadvisering hun eigen vakgebied te beoordelen naar de mate waarin hun vakgebied zich heeft ontwikkeld tot een professie. Daarnaast werd aan acht experts uit vakgebieden die reeds een professie genoemd worden gevraagd hun eigen vakgebied te beoordelen naar de mate waarin hun vakgebied een professie is. Hoewel aan alle elf beoordelende experts werd gevraagd dat te doen op basis van zestien criteria voor een professie, dienen de resultaten van dit onderzoek vanwege het beperkte aantal beoordelingen alleen beschouwd te worden als een 'eerste indruk' van de mate waarin loopbaanadvisering zich ontwikkeld heeft tot een professie.

In Hoofdstuk 4 inzake ethiek werden 170 casusvoorbeelden, uit evenveel bestaande dossiers, die waren opgesteld door kandidaten voor certificering als loopbaanadviseur onderzocht. Casusvoorbeelden zijn per definitie subjectief. Het feit dat de beoordeling van het ethisch handelen, zoals door adviseurs beschreven, werd uitgevoerd door drie experts op het gebied van loopbaanadvisering vermindert de subjectiviteit van de data enigszins, hetgeen de betrouwbaarheid van de resultaten van dit hoofdstuk ten goede komt. 
In Hoofdstuk 5 inzake de specifieke competenties van de loopbaanadviseur werden 500 casusvoorbeelden, die per definitie subjectief zijn, uit 100 bestaande dossiers van kandidaten voor certificering als loopbaanadviseur onderzocht. Om de betrouwbaarheid van de resultaten van dit onderzoek te vergroten werd elk casusvoorbeeld door drie experts op het gebied van loopbaan-advisering op kwaliteit beoordeeld. Daarbij is ook onderzocht of de resultaten anders zouden zijn als de oordelen van de auteur van dit proefschrift (die deel uitmaakte van het expertpanel) niet zouden worden meegenomen. Dat bleek niet het geval te zijn.

In Hoofdstuk 6 inzake de arbeidsmarktbegeleiding werden 150 casusvoorbeelden uit bestaande dossiers van te certificeren kandidaten onderzocht. Alle casusvoorbeelden, die per definitie subjectief zijn, werden door een expertpanel eerst beoordeeld op 'categorie' van arbeidsmarktbegeleiding en vervolgens op kwaliteit. Om de betrouwbaarheid van de resultaten van dit onderzoek te vergroten werd het beoordelen steeds uitgevoerd door drie experts op het gebied van loopbaanadvisering.

In Hoofdstuk 7 werden de effecten van loopbaanbegeleiding onderzocht door middel van enquêtes, die werden gestuurd aan loopbaanadviseurs. Om de betrouwbaarheid van de resultaten van dit onderzoek te vergroten werd de enquête tevens gestuurd aan twee aanvullende bronnen, te weten de cliënten en opdrachtgevers van deze loopbaanadviseurs. Vervolgens werden de data van de adviseurs gematched met de data van de twee aanvullende bronnen (cliënten en opdrachtgevers). Er bleken 225 matches gerealiseerd te kunnen worden uit in totaal 450 enquêteformulieren, hetgeen de betrouwbaarheid van de resultaten aanzienlijk ten goede komt.

Controlegroep: Een tweede belangrijke beperking voor een aantal van de onderzoeken uit dit proefschrift betreft het ontbreken van een controlegroep. 
Hierdoor kan niet met zekerheid worden gezegd dat de gevonden resultaten werkelijk aan de interventie toegeschreven kunnen worden. Dit geldt met name voor Hoofdstuk 7, waarin aan de hand van enquêtes de effecten van de loopbaanbegeleiding onderzocht werden. Het ontbreken van een controlegroep werd in dit hoofdstuk enigszins gecompenseerd door toepassing van 'the Theory of Change' (veranderingstheorie) van Weiss (1972), waardoor in ieder geval een waardevolle indicatie gegeven kon worden van de effecten van loopbaanbegeleiding.

Selectieve respons: bij het gebruik van enquêtes, zoals in Hoofdstuk 7 , wordt er van buitenaf een selectie gemaakt, waardoor er door een bepaalde groep niet meegedaan wordt. Daarnaast kan er sprake zijn van selectieve respons als de vragenlijst om een bepaalde reden door de non-respondenten niet is beantwoord, aangezien het resultaat dan vertekend zou kunnen worden. In dat hoofdstuk kan het voorgekomen zijn dat cliënten of opdrachtgevers die niet tevreden zijn over hun adviseur de vragenlijst bewust niet hebben beantwoord. Daarnaast kan er selectieve uitval zijn opgetreden, doordat een aantal van de adviseurs van hun bovengeschikte geen enquêteformulier in mochten leveren. De in dat hoofdstuk gevonden resultaten kunnen hierdoor enigszins vertekend zijn.

Aanbevelingen uit de vier onderzoekhoofdstukken van dit proefschrift

Toen het echtpaar Heppner en Heppner in 2003 met hun artikel "Identifying process variables in career counseling: A research agenda" opriepen tot meer onderzoek op het gebied van loopbaanbegeleiding, konden zij niet bevroeden dat het tot 2018 zou duren voordat effecten van de begeleiding op de middellange termijn zouden worden onderzocht. Op basis van de bevindingen van het onderhavige onderzoek zullen zowel aanbevelingen voor verder onderzoek en onderwijs op het terrein van de loopbaanadvisering als aanbevelingen voor de beroepspraktijk worden gedaan. 
Theoretische aanbevelingen

Controlegroep: voor verder onderzoek zou het zeer nuttig zijn om ook een doelgroep van loopbaanadviseurs, die niet gecertificeerd is, naast de huidige doelgroep te plaatsen. Op deze manier zou een controlegroep kunnen worden gecreëerd, waardoor de conclusies van dit proefschrift geverifieerd zouden kunnen worden. Dan zal ook blijken of er met de 'Theory of Change' van Weiss (1972) tot dezelfde conclusies gekomen kan worden als met behulp van een controlegroep. Dan zal blijken in hoeverre de begeleiding verschilt tussen de twee groepen, indien in de onderzochte groep de begeleiding bijvoorbeeld wel gericht is op verbetering van het zelfbeeld en in de controlegroep deze interventie achterwege gelaten wordt.

Stabiele hoge effecten inzake loopbaanbegeleiding op korte en middellange termijn: het was reeds lang een vermoeden, maar het is door het onderhavige onderzoek voor het eerst aangetoond dat er een hoge mate van tevredenheid met de begeleiding van de cliënt zowel op korte en middellange termijn bestaat. Dat wil niet zeggen dat op dit vlak geen vervolgonderzoek nodig is. Het zou goed zijn om met behulp van de CMI-certificeringdossiers onderzoek te entameren naar vooral de lange-termijneffecten van loopbaanbegeleiding en baantevredenheid, maar ook om het onderzoek naar de ontwikkelaspecten verder te completeren. Daarbij zijn de dossiers van CMI immers authentiek materiaal voor praktijkgericht veldonderzoek.

De aanbeveling is dan ook om met CMI het dossier voor certificering, alsook het dossier voor re-certificering, zodanig in te richten, dat korte- en middellangetermijneffecten, maar ook lange-termijneffecten in circa zes jaar tijd te onderzoeken zijn. Dat zou uiterst nuttig zijn voor de verdere ontwikkeling van het vakgebied in Nederland. Omdat de veelheid en de verscheidenheid van casusvoorbeelden op het gebied van loopbaanadvisering zo uniek is, zou hiermee de ontwikkeling van het 
vakgebied in de richting van een professie niet alleen in Nederland, maar ook internationaal via certificering bijzonder geholpen kunnen worden.

Grootschalig onderzoek naar mate van ontwikkeling loopbaanadvisering tot professie: aanbevolen wordt om voor het vakgebied van de loopbaanadvisering een veel groter onderzoek te doen op basis van de criteria van Greenwood en Maas. Het onderhavige onderzoek, waarbij elf respondenten een enquête invulden, kan slechts een indruk verschaffen van de ontwikkeling naar een professie. Om daarvan een goed beeld te kunnen geven is het aantal respondenten in dit onderzoek te gering. Daarom zou een grotere enquête opgezet moeten worden op basis van de criteria van Greenwood en Maas, waarbij naast de eigen beroepsgroep ook de beroepsgroepen die de andere acht professies vertegenwoordigen betrokken zouden moeten worden. Het advies is om te beginnen met een onderzoek onder Nolocleden, waardoor een betrouwbaar beeld verkregen kan worden van de mate waarin loopbaanadvisering op weg is naar een professie. De betrouwbaarheid zou verder vergroot worden als de uitkomsten vergeleken zouden worden met de uitkomsten van de acht beroepsgroepen die reeds een professie genoemd worden, dit in analogie met het mini-onderzoek in het onderhavige proefschrift.

De wijze van begeleiding: het onderzoek beperkt zich tot het effect van de begeleiding voor de cliënt. Daarbij is de wijze van begeleiding niet specifiek onderzocht. Dat gaat bijvoorbeeld om de vraag hoe de adviseur zijn of haar inlevingsvermogen gebruikt om het zelfbeeld van de cliënt te verbeteren, of om de vraag hoe door coaching een verandering in het zelfsturend vermogen van de cliënt teweeggebracht kan worden. Het blijkt dat de te certificeren loopbaanadviseurs voldoende bedreven zijn in het begeleiden van cliënten met hun loopbanen, anders zouden de uitkomsten van de begeleiding minder hoog geweest zijn, maar we weten niet op welke wijze de adviseurs deze uitkomsten door hun begeleiding hebben 
gerealiseerd. Een dergelijke vraag zou gemakkelijk ingelast kunnen worden als casusvoorbeeld voor de certificering. De aanbeveling is dan ook om hierover met het bestuur van CMI in overleg te treden.

Wel en niet gecertificeerde adviseurs: door gebruik te maken van de CMIcertificeringsdossiers richtte dit proefschrift zich op de vakbekwame loopbaanadviseurs. Maar het zou interessant kunnen zijn om er een doelgroep naast te plaatsen van niet-gecertificeerde adviseurs. Op deze manier zou er een vergelijking kunnen worden gemaakt tussen de kwaliteit van de wel en niet gecertificeerde loopbaanadviseurs. Omdat er bij Noloc nog relatief weinig loopbaanadviseurs gecertificeerd zijn, zou een oproep via Noloc om mee te doen aan een groot onderzoek naar de effecten van de begeleiding succesvol kunnen zijn om de kwaliteit van begeleiding door niet-gecertificeerde adviseurs te achterhalen!

Onderzoek naar de ontwikkeling van meer competenties: voor de cliënt zelf blijkt de relatie tussen de verbetering van het functioneren en de verbetering van de relatie met de werkomgeving zeer sterk te zijn. Die kennis is voor de adviseur belangrijk. Meer onderzoek naar dit soort relaties lijkt verstandig, omdat uit het onderhavige onderzoek bleek dat de relaties tussen de specifieke competenties beperkt waren. Het beantwoorden van de vraag welke van deze competenties samenhangen en welke niet vergt veel onderzoek. De praktijk van het vakgebied zou daar echter in hoge mate profijt van kunnen hebben.

Men kan zich daarnaast afvragen of de door CMI gebruikte competenties wel toereikend zijn om als specifieke competenties voor de begeleiding van de cliënten door de loopbaanadviseurs ingezet te worden. Mogelijk zijn er andere competenties die meer kenmerkend zouden zijn om enkele van de bestaande specifieke competenties te vervangen. Nader onderzoek naar bijvoorbeeld de 160 competenties van Ofman (1992) zou behulpzaam kunnen zijn. Voorbeelden van deze competen- 
ties zijn: baanbrekend, confronterend, openheid, relativerend vermogen, zelfinzicht en zelfbewustheid. Als enkele van deze competenties belangrijk blijken te zijn voor de kwaliteit van de loopbaanadvisering, zou dat voor de kwaliteit van de CMItoetsing, maar ook voor kwaliteit van het vakgebied als geheel, belangrijke informatie opleveren.

Specifieke werkervaring: het onderzoek liet zien dat de kwaliteit van de arbeidsmarktbegeleiding niet gerelateerd was aan de specifieke werkervaring van de loopbaanadviseurs. Dit is opmerkelijk, aangezien er wel een verband werd gevonden tussen de kwaliteit van de arbeidsmarktbegeleiding en het CMI-niveau, dat gerelateerd is aan de specifieke werkervaring. Nader onderzoek naar deze relaties zou uitkomst kunnen bieden. Ook het feit dat een adviseur met meer specifieke werkervaring cliënten niet beter kan helpen zich te verbeteren op de vijf ontwikkelaspecten dan een adviseur met minder specifieke werkervaring is opmerkelijk. Beide constateringen werden niet verwacht en worden door de auteur van dit proefschrift vreemd gevonden, waardoor nader onderzoek aanbevolen wordt.

Verbetering van het zelfsturend vermogen via het zelfbeeld, het zelfinzicht en het zelfvertrouwen: het onderhavige onderzoek laat zien dat de verbetering van het zelfbeeld en de zelfsturing van de cliënt volgens de loopbaanadviseur sterk aan elkaar gerelateerd zijn. Volgens Kidd et al. (2003) verbetert ook het zelfvertrouwen door verbetering van het zelfinzicht, terwijl Verbruggen en Sels (2008) laten zien dat het zelfsturend vermogen verbetert door meer zelfvertrouwen. Deze constateringen willen echter nog niet zeggen dat alle vier mogelijke aspecten sterk aan elkaar gerelateerd zouden zijn. Verder onderzoek lijkt voor de hand te liggen, vooral naar de samenhang op de langere termijn. 
Baantevredenheid: dit onderzoek wijst uit dat de baantevredenheid van de cliënten voor een groot gedeelte verklaard wordt door de verbetering van het functioneren, en in mindere mate door het verbeteren van de relatie met de werkomgeving. Wanneer een medewerker verzocht wordt om een loopbaanadviseur te consulteren, is dit veelal omdat diegene minder goed functioneert. Het is merkwaardig dat er in het onderhavige onderzoek geen relatie werd gevonden tussen het verbeteren van het zelfsturend vermogen van de cliënt en diens baantevredenheid. Verbruggen en Sels (2008) vinden in hun studie over zelfsturend vermogen juist een sterke relatie met tevredenheid inzake de (loop)baan., maar niet over de verbetering van het functioneren. Het is echter moeilijk om beide studies te vergelijken, omdat Verbruggen en Sels (2008) de andere ontwikkel-aspecten uit de onderhavige studie niet hebben meegenomen. Het is mogelijk dat in de onderhavige studie zelfsturing minder verklaringskracht heeft, doordat andere factoren, zoals functioneren en relatie met de werkomgeving, juist belangrijker geacht worden. Verder onderzoek zou nuttig zijn en wordt aanbevolen.

\section{Aanbevelingen voor de praktijk}

Ontwikkeling naar een professie: de beroepsgroep zal een ontwikkeling naar een professie zelf dienen door te zetten. Het streven naar een professie heeft ook direct te maken met legitimatie door de overheid, wetenschappelijk onderzoek naar de impact van loopbaanadvisering en vooral maatschappelijke erkenning. De verwerving van legitimatie door de overheid zal op zich niet problematisch zijn, aangezien de overheid het belang van loopbaanadvisering reeds erkent en de eigen loopbaan-adviseurs reeds laat certificeren. De overheid zal er echter nog van overtuigd moeten worden dat loopbaanadvisering als beroepsgroep essentieel is om mensen in werknood te begeleiden en daardoor een essentiële plaats inneemt in het 
maatschap-pelijke bestel. Slechts dan kan ook maatschappelijke steun en erkenning worden verworven. Als de overheid het belang van loopbaanadvisering niet ziet en stimuleert, zal maatschappelijke erkenning door het grote publiek zeker niet worden verworven. Goede contacten van de beroepsgroep met de centrale overheid zijn daarvoor essentieel.

De beroepsgroep zal daarnaast zelf ook aan het grote publiek duidelijk moeten maken dat het begeleiden van mensen in werknood een groot effect heeft. Daarbij zal wetenschappelijk onderzoek ook meer inzicht moeten geven in de maatschappelijke betekenis van loopbaanadvies. Het ontwikkelproces naar een professie kan echter nog decennia duren. Pas als de maatschappij ervan overtuigd is dat loopbaan-advisering een vitale rol zal kunnen spelen voor de mens in werknood en dit door onderzoek bevestigd zal worden, zal er sprake kunnen zijn van de realisatie van loopbaanadvisering als professie.

Een masteropleiding: het lijkt nog te vroeg om een masterdiploma voor loopbaanadvisering aan te bevelen voor de zelfstandige uitvoering van loopbaanadvisering. Wil loopbaanadvisering werkelijk op termijn een professie worden, dan zal echter naar de mening van de auteur van dit proefschrift de aanbeveling moeten zijn dat, naast de certificering, op den duur ook een masterdiploma verlangd dient te worden voor zelfstandig werkende adviseurs die op CMI C-niveau willen werken. Immers, geen enkele beroepsgroep wordt in de volksmond een professie genoemd zonder van zelfstandig werkende adviseurs een masterdiploma te verlangen. De realisatie hiervan zal gecompliceerd zijn en in ieder geval gesteund moeten worden door de beroepsgroep zelf en door de overheid. Daarbij zal er een studierichting loopbaanadvisering op wo-niveau verder moeten worden ontwikkeld. 
Ethiek: een belangrijke aanbeveling die uit het onderhavige onderzoek volgt is dat er meer aandacht dient te komen voor ethiek bij loopbaanbegeleiding. Duidelijk werd aangetoond dat loopbaanadviseurs met minder ervaring en breedte in loopbaanproblematiek (dus een "smaller" CMI-niveau) in het algemeen minder goede casusvoorbeelden presenteren inzake ethische dilemma's dan hun collegae die een breder niveau hebben. Het is van belang dat de loopbaanadviseur niet alleen gewezen wordt op zijn of haar kwetsbare positie in de beschreven driehoeksrelatie van adviseur, cliënt, en opdrachtgever, maar dat er tijdens de opleiding van de adviseur ruime aandacht aan ethisch handelen wordt gegeven en met name aan het ethisch dilemma, dat veelvuldig voorkomt in de driehoeksverhouding adviseur, cliënt en opdrachtgever.

Bovendien verdient het aanbeveling dat de adviseur niet alleen tijdens de certificering, maar ook tijdens de re-certificering, getoetst wordt op de kwaliteit van het ethisch handelen, zodat de onderkenning van ethische problematiek bij de loopbaanadviseurs groeit. Naast kennis wordt intuïtie in de praktijk en ook in de literatuur (Haidt, 2001) genoemd als belangrijke factor om gevoel voor het onderkennen van ethische kwesties in het kader van loopbaanadvisering te krijgen. Ook speelt bewustwording een belangrijke rol. Derhalve is training en verdere ontwikkeling van de loopbaanprofessional op het gebied van ethiek een eerste vereiste en van harte aanbevolen. Het hoofdstuk over ethiek heeft laten zien hoe noodzakelijk dit is.

Train de trainer: De communicatieve vaardigheden worden in de ogen van de adviseur door begeleiding het minst verbeterd. Het gebrek aan communicatieve vaardigheden is in de praktijk veelal de oorzaak van het minder functioneren. Cliënten die minder verbetering in hun communicatieve vaardigheden ondervonden blijken volgens de adviseurs ook minder verbetering van hun 
functioneren te ondervinden als gevolg van de begeleiding. Omdat goede communicatieve vaardigheden ook in het proces van het vinden van een passende werkkring uiterst belangrijk zijn, zou verder onderzoek nuttig zijn om uit te zoeken op welke wijze deze vaardigheden bij de cliënt van loopbaanbegeleiding verder geactiveerd kunnen worden. Dat zou bij kunnen dragen aan een sterkere verbetering van alle ontwikkelaspecten bij deze cliënten en daarmee aan de kwaliteit van de uitvoering van het vak. Daarnaast zal de adviseur zelf ook meer aandacht aan de communicatieve vaardigheden moeten geven. Het is dan ook belangrijk voor de loopbaanadviseur om zelf de training van de communicatieve vaardigheden van zijn of haar cliënten ter hand te nemen. Waarschijnlijk is het dan noodzakelijk dat de loopbaanadviseur ook zelf getraind wordt om de training van de cliënten te verrichten. Train de trainer is dus het devies.

Arbeidsmarktbegeleiding: voor een belangrijk onderwerp als de kwaliteit van de arbeidsmarktbegeleiding bleek dat slechts iets meer dan de helft van de casusvoorbeelden een voldoende beoordeling kreeg. Door goede netwerken kunnen loopbaanadviseurs onderling gebruik maken van elkaars marktexpertise. Sociale media maken goed netwerken aanzienlijk eenvoudiger dan voorheen. Om verbetering in de kwaliteit van de arbeidsmarktbegeleiding te brengen, zal vooral veel meer aandacht geschonken moeten worden aan het aspect van bijhouden van de ontwikkelingen op de arbeidsmarkt door de loopbaanadviseur. Een belangrijk thema als de begeleiding van de cliënt in de arbeidsmarkt zou veel hoger moeten scoren. De kennis van de ontwikkeling van de arbeidsmarkt en de begeleiding in de arbeidsmarkt zal een meer prominente plaats moeten krijgen. Praktijkervaring door stages zouden studenten meer inzicht kunnen geven in de dynamiek van de arbeidsmarkt. Daarnaast kan CMI meewerken door de samenwerking tussen theorie en praktijk te verstevigen, zoals in de loop van 2017 reeds gebeurde door het 
beschikbaar stellen van stageplaatsen en loopbaanadviseurs tevens aan te moedigen zich academisch te bekwamen. Aan te bevelen is om de ontwikkeling van de categorieën goed te volgen, door bijvoorbeeld via CMI periodiek nieuwe casusvoorbeelden in kaart te brengen, waardoor de ontwikkeling van de arbeidsmarkt goed gevolgd kan worden.

NICE Network: voor de toekomst is het zaak om de kennis over de loopbaanadvisering die in Europa wordt verzameld, te assimileren. Zoals dit proefschrift laat zien, zijn de casusvoorbeelden van de te certificeren loopbaanprofessionals daarbij van grote betekenis, mits de gebruikte competenties in Europa op elkaar afgestemd worden. Het NICE Network heeft een begin gemaakt om het wetenschappelijk onderzoek op dit terrein te stimuleren. Bovendien wil het NICE-bestuur certificering voor heel Europa opzetten naar voorbeeld van het Nederlandse certificeringssysteem op basis van ISO. Dat wordt door de auteur van dit proefschrift sterk aanbevolen.

Trait d'union: in een studie over competenties van loopbaan-advisering (Schiermann et al., 2016) zijn de loopbaanadviseurs onderverdeeld in drie groepen: amateurs, professionals en specialisten. De stelling in die studie is dat er veel meer aandacht dient te worden besteed aan de "amateurs", zoals docenten in het onderwijs, die vaak als eersten door leerlingen, studenten, maar ook door volwassenen, worden aangesproken als het gaat om loopbaanvraagstukken. Daarbij kunnen amateurs een belangrijke trait d'union vormen tussen toekomstige cliënten en loopbaanprofessionals. De aanbeveling is dan ook om deze structuur in Nederland te overwegen. Met betrekkelijk weinig middelen zouden "amateurs" veel voorbereidend werk kunnen doen.

Overtuigen van (nieuwe) opdrachtgevers: de gevonden sterke verbetering van het functioneren van de cliënten als gevolg van de begeleiding in de perceptie van de 
opdrachtgever dient onder de aandacht van mogelijk nieuwe opdrachtgevers te worden gebracht om hen ervan te overtuigen hoe waardevol loopbaanadvisering is om het functioneren van medewerkers te verbeteren. Daarbij gaat het voor de organisaties natuurlijk meer om loopbaancoaching en loopbaanbegeleiding in de organisatie dan om outplacement, waardoor medewerkers beter gaan functioneren in hun huidige functie, maar terzelfdertijd ook beter gaan communiceren en beter gaan samenwerken op de werkvloer. Door de begeleiding van de cliënt verbeteren alle drie deze ontwikkelaspecten volgens de opdrachtgevers immers in sterke mate. Welke werkgever zou daar niet voor tekenen. 



\section{ADDENDUM: \\ DE WAARDE VAN HET PROEFSCHRIFT VOOR DE MAATSCHAPPIJ}

Dit proefschrift bevat verschillende aspecten die voor de maatschappij van waarde zijn. Deze aspecten zullen hieronder kort besproken worden.

Relevantie van het proefschrift

Dit proefschrift onderzoekt de kwaliteit van loopbaanadvisering in de private sector in Nederland. Indirect wordt hierdoor de waarde van het vakgebied voor de maatschappij onderzocht en met name in welke mate loopbaanadvisering zich ontwikkeld heeft tot een professie. Maar in feite is het proefschrift een pleidooi om loopbaanadvisering serieus te nemen als instrument om werkloosheid effectief aan te pakken. Het proefschrift laat een aantal relevante resultaten en ontwikkelingen zien.

1) De verbetering van de ontwikkelaspecten van clienten door begeleiding: het functioneren van de cliënten verbetert door de begeleiding aanzienlijk. Ook de communicatie van de cliënten met derden verbetert; tevens ontstaat een verbeterde relatie met de werkomgeving. 2) Tevredenheid met de begeleiding: de hoge mate van tevredenheid van de cliënten over de begeleiding werd zowel op de korte als op de middellange termijn aangetoond. De tevredenheid van de cliënt op middellange termijn werd al lange tijd vermoed, maar werd nog niet eerder aangetoond. 3) Baantevredenheid: met name de hoge mate van baantevredenheid toont aan dat loopbaanbegeleiding zeer relevant is voor cliënten in werknood en dat deze begeleiding daardoor van grote waarde is voor de maatschappij als geheel.

4) Ethiek en Arbeidsmarktbegeleiding: het proefschrift laat zien dat zowel het omgaan met een ethisch dilemma als de begeleiding van de cliënten naar de 
arbeidsmarkt door loopbaanadviseurs nog onder de maat zijn. Het is voor de maatschappelijke waarde van het vakgebied van groot belang dat deze resultaten gekend worden. Bovendien zou er prioriteit gegeven dienen te worden aan het verbeteren van deze beide aspecten door voor beide meer aandacht te vragen in het curriculum van zowel de hbo- als de wo-opleidingen.

5) Preventieve periodieke loopbaanbegeleiding: In Hoofdstuk 2 van dit proefschrift werd gewezen op de trend om meer preventief te begeleiden. Ook het SER-advies (2017) 'Leven Lang Ontwikkelen' wijst op het grote belang van een preventieve loopbaancheck voor de employability van de Nederlandse beroepsbevolking, zoals dat in België al een aantal jaren in de praktijk gebracht wordt. Een periodieke preventieve loopbaancheck door vakbekwame loopbaanadviseurs zou voor de maatschappij een zeer goed middel zijn om werkloosheid te beperken. Hopelijk zal dit proefschrift ertoe bijdragen dat een periodieke APK-check op korte termijn gerealiseerd wordt. Dat zou een waardevolle maatschappelijke bijdrage zijn.

\section{Doelgroepen}

De onderzoekresultaten zijn interessant voor een aantal doelgroepen in het kader van loopbaanadvisering, te weten: voor de loopbaanadviseurs zelf, de cliënten, de opdrachtgevers, de overheid en opleidingsinstituten, en dan met name voor wo-opleidingen. Vanzelfsprekend zijn de resultaten ook belangrijk voor de branchevereniging, de beroepsvereniging en de certificerende instelling op het gebied van loopbaanadvisering. Voor de loopbaanadviseurs zelf is het proefschrift interessant; door het lezen van het proefschrift zouden de adviseurs meer vertrouwen kunnen krijgen in hun eigen vakgebied. Het proefschrift toont aan dat het vakgebied zich in de afgelopen veertig jaar goed heeft ontwikkeld in de richting 
van een professie, maar dat er nog wel onderwerpen binnen het vakgebied zijn waar meer aandacht aan besteed moet worden, zoals ethiek en arbeidsmarktbegeleiding.

Voor (potentiële) cliënten is het proefschrift zeker ook relevant. Het proefschrift maakt duidelijk dat cliënten er baat bij hebben om begeleid te worden. Cliënten blijken vaak zeer tevreden over de begeleiding zelf, maar zeker ook over de baan die ze na begeleiding hebben verworven. HRM-managers zouden dit veel duidelijker naar voren moeten brengen. Vooral aan vertrekkende medewerkers zou het belang van de begeleiding veel duidelijker gemaakt moeten worden. Helaas kiezen medewerkers veelal voor een geldpremie in plaats van voor begeleiding. HRMmanagers met de kennis van de resultaten van dit proefschrift zouden aan deze medewerkers veel duidelijker moeten maken dat loopbaanbegeleiding voor hun toekomst van veel grotere waarde is dan een eenmalig bedrag als vertrekpremie.

Voor (potentiële) opdrachtgevers en hun HRM-managers is het proefschrift zeker ook belangrijk. Het toont aan dat er een hoge mate van tevredenheid is bij opdrachtgevers over de begeleiding van hun medewerkers. In de perceptie van die opdrachtgevers die ervaring met loopbaanadvisering hebben, heeft loopbaanbegeleiding een positief effect op zowel het functioneren van hun medewerkers, als ook op hun communicatieve vaardigheden en op hun relatie met hun werkomgeving.

Ook voor de overheid is dit proefschrift interessant. Door de inzet van loopbaanadvisering kan, waar nodig, de mobiliteit binnen de overheid aanzienlijk vergroot worden. Dat is zeker van belang voor de overheid als werkgever van medewerkers waarvan het functioneren dient te verbeteren. Bovendien geeft dit proefschrift aan dat het belangrijk is om loopbaanadvisering door betere opleiding en scholing van de loopbaanadviseurs goed op de kaart te zetten. Dat is een typische overheidstaak. Dat er na veertig jaar ervaring met loopbaanadvisering als vakgebied 
in Nederland nog maar vier hbo-opleidingen zijn en voor de enige wo-opleiding nog maar één parttime hoogleraar beschikbaar is, is in vergelijking met het buitenland mager. Universiteiten zouden meer wo-opleidingen gericht op loopbaanadvisering moeten aanbieden, aangezien de markt behoefte heeft aan professionals op dit niveau. Gezien de doelmatigheid van het vak, die onder meer uit het onderhavige proefschrift zo duidelijk blijkt, kan de financiering van woopleidingen dan niet lang uitblijven. Dat de overheid daarnaast belang heeft bij een verdere ontwikkeling van loopbaanadvisering in de commerciële sector ligt voor de hand. Traditioneel was de financiering van mensen die om wat voor reden dan ook in de knel kwamen, een overheidstaak. Begeleiding van mensen in werknood zonder hulp van de publieke sector is nog steeds ondenkbaar. Op zich is dat een goede zaak. Meer begeleiding op commerciële basis zou echter een besparing van publieke middelen met zich mee brengen. Maar dan zou de overheid er wel eerst voor moeten zorgen dat er voldoende loopbaanadviseurs op wo-niveau worden opgeleid.

Ten slotte is dit proefschrift zeker ook relevant voor loopbaanadvisering als sector. Dus voor de branchevereniging en de beroepsvereniging, maar zeker ook voor CMI, als certificerende instelling. Het proefschrift heeft immers aangetoond dat cliënten over het algemeen zeer tevreden zijn met de door hen dankzij de begeleiding nieuw verworven baan. En dat deze waardering ook drieënhalf jaar na de begeleiding beklijft. Dat is voor de gehele sector en dus met name voor de branche- en beroepsvereniging van grote betekenis om aan de maatschappij te laten zien hoe relevant het vakgebied is voor de werkende gemeenschap in Nederland. Dat ook de certificerende instelling als toetsende instelling voor vakbekwaamheid van de loopbaanadviseurs daar een belangrijke kwalitatieve rol in kan vervullen, behoeft nauwelijks betoog. 


\section{Concrete producten}

Dit onderzoek heeft geleid tot meerdere concrete producten. Het onderzoek laat ten eerste zien hoe sterk de onderlinge samenhang tussen de verbetering van de vijf belangrijke ontwikkelaspecten van de cliënt door de begeleiding is. Bovendien geldt deze samenhang niet alleen in de ogen van de cliënt, maar ook vanuit het perspectief van zowel de adviseur als vanuit dat van de opdrachtgever. Ook laat het proefschrift zien dat de tevredenheid over de loopbaanbegeleiding niet alleen op de korte termijn, maar ook op de middellange termijn hoog is. In de perceptie van de adviseur blijkt de tevredenheid van de cliënten na een periode van drieënhalf jaar zelfs zeer hoog. Voorts blijkt ook de tevredenheid van de cliënten na een periode van drieënhalf jaar even hoog te zijn als kort na de begeleiding. Voor de cliënt kan dat nauwelijks anders verklaard worden dan door de sterke emotie van de cliënt als gevolg van werknood, die in ieder geval nog drieënhalf jaar na de begeleiding doorwerkt.

Ook is voor het eerst aangetoond dat opdrachtgevers zowel op de korte als de middellange termijn zeer tevreden zijn over de begeleiding van hun medewerkers. Bovendien is de tevredenheid van opdrachtgevers over de begeleiding van de adviseur na drieënhalf jaar zelfs hoger dan de tevredenheid op de korte termijn. Gezien de resultaten van dit proefschrift zouden de loopbaanadviseurs zelf de maatschappelijke waarde van loopbaanadvisering aan potentiële opdrachtgevers (met name ook voor coaching) zeer goed duidelijk kunnen maken. Met name door te wijzen op de verbeteringen die door de advisering teweeggebracht worden in van het functioneren van de cliënt, alsmede in diens communicatieve vaardigheden en in diens relatie met de (bestaande) werkomgeving. 


\section{Innovatie}

Het proefschrift geeft op een aantal punten nieuwe inzichten. Belangrijk voor de wetenschap is het feit dat aangetoond kon worden dat de hoge tevredenheid van zowel de cliënt als van de opdrachtgever over de begeleiding van de adviseur niet alleen op de korte termijn speelt maar zeker ook op de middellange termijn. Daarnaast is het voor het vak van loopbaanadvisering van belang te weten dat er zowel ten aanzien van ethiek als van arbeidsmarktbegeleiding nog een slag gemaakt moet worden om adviseurs voor deze twee belangrijke deelgebieden beter te positioneren. Inzake ethiek laat het proefschrift zien dat er nog veel schort aan de herkenning van ethische dilemma's door de loopbaanadviseurs. Daarom zal CMI het omgaan met ethische dilemma's niet alleen moeten toetsen bij de initiële certificering, maar eveneens bij de eerste en tweede re-certificering.

Het proefschrift laat ook zien dat loopbaanadviseurs te weinig kennis van de arbeidsmarkt in huis hebben. Zo blijkt dat de kwaliteit van de casusvoorbeelden van de arbeidsmarktbegeleiding over het algemeen tegenvalt: $10 \%$ van de casusvoorbeelden bevat een onvoldoende professioneel voorbeeld van de arbeidsmarktbegeleiding. Ook werden casusvoorbeelden inzake psychologische begeleiding gegeven in plaats van de gevraagde voorbeelden over de arbeidsmarkt. Door specialisatie zou de kwaliteit van de begeleiding verbeterd kunnen worden. Dit zou de arbeidsmarkt voor de loopbaanadviseurs ook veel overzichtelijker maken. Daarbij moet ook het opdoen van praktijkervaring door middel van stages gestimuleerd worden.

Naast nieuwe inzichten die in het proefschrift tot innovatieve resultaten geleid hebben, zijn er als gevolg van het onderzoek tevens nieuwe inzichten gekomen die niet direct leiden tot nieuwe resultaten, maar die door nader onderzoek daartoe wel aanleiding kunnen geven. De belangrijkste suggesties voor verder 
veldonderzoek volgen hieronder, zodat de geïnteresseerde lezer, in het korte bestek van dit addendum, de suggesties voor verder innovatief veldonderzoek snel op een rij heeft.

De controlegroep: In het onderzoek in Hoofdstuk 7 was het niet mogelijk om met een controlegroep te werken. Derhalve werd gewerkt met 'the Theory of Change' van Weiss (1972), waardoor korte en middellange effecten zo goed mogelijk konden worden onderzocht zonder controlegroep. Om het resultaat op basis van de methodiek van Weiss te verifiëren, zou het nuttig zijn om de uitkomsten van het onderhavige onderzoek, dat plaatsvond met een groep cliënten die door gecertificeerde loopbaanadviseurs begeleid werden, te vergelijken met een groep cliënten die niet begeleid werden, maar voorts van dezelfde samenstelling is. Wordt voor deze twee groepen een verbetering van het loopbaanperspectief onderzocht, dan zouden er verschillen in uitkomsten moeten optreden. Het verschil zou dan bijvoorbeeld tot uiting moeten komen door een verschil in de gevonden verbetering van de ontwikkelaspecten en de baantevredenheid van cliënten op korte of (middel)lange termijn. Ook de stabiliteit van het tevredenheidseffect als gevolg van de begeleiding zou op deze wijze op korte en middellange termijn geverifieerd kunnen worden.

Loopbaanadvisering op weg naar een professie: In dit proefschrift werd op basis van zestien criteria op kleine schaal onderzocht in hoeverre loopbaanadvisering verschilt van andere beroepsgroepen die in de volksmond een professie genoemd worden. Het mini-onderzoek betrof elf deelnemers, te weten: drie experts voor loopbaanadvisering en acht experts voor acht beroepsgroepen die een professie genoemd worden. De uitkomsten van het onderzoek kunnen slechts een eerste indruk geven van de ontwikkeling van loopbaanadvisering tot nu toe. Om de betrouwbaarheid te vergroten zou een veel groter onderzoek nodig zijn om de 
ontwikkeling van loopbaanadvisering op weg naar een professie op de voet te volgen. Dat zou kunnen door periodiek aan de beroepsgroep via de beroepsvereniging de genoemde zestien criteria voor te leggen.

Wijze van begeleiding: Het onderzoek in dit proefschrift heeft zich beperkt tot het effect van loopbaanbegeleiding. We weten als gevolg van het onderzoek dat zowel de verbetering van het functioneren als de verbetering van de relatie met de werkomgeving een sterke samenhang hebben met de baantevredenheid van de cliënt. We weten ook dat door deze twee ontwikkelaspecten de baantevredenheid voor $44 \%$ wordt verklaard. Maar we hebben niet onderzocht op welke wijze de adviseurs dit hebben weten te realiseren. Om loopbaanadvisering goed op de kaart te zetten, zou verder onderzoek naar de wijze van de begeleiding een zeer nuttige aanvulling zijn op de vraag welke methode van begeleiding het meest effectief is voor een optimaal resultaat.

Ontwikkeling van competenties van de loopbaanadviseur: In dit proefschrift zijn vijf specifieke competenties onderzocht. De voorbeelden die de gecertificeerde loopbaanadviseurs inzake de specifieke competenties gaven werden over het algemeen als 'goed' beoordeeld. Er was echter weinig samenhang tussen de mate van ontwikkeling van de specifieke competenties onderling. Mogelijk zouden andere competenties die van belang zijn voor de begeleiding van cliënten beter werken. Ofman (1992) noemt 160 competenties. Onderzoek naar welke van deze competenties het meest effectief zijn om cliënten goed te begeleiden, kan voor het vakgebied van grote betekenis zijn.

Verbetering van het zelfsturend vermogen: Dit onderzoek heeft laten zien dat de verbetering van het zelfsturend vermogen sterk gerelateerd is aan de verbetering van het zelfbeeld. Andere auteurs laten zien dat er tevens sterke relaties zijn tussen de verbetering van het zelfinzicht en de zelfsturing als ook tussen de verbetering 
van het zelfvertrouwen en van het zelfsturend vermogen. Nieuw zou zijn om de relatie tussen alle vier ontwikkelaspecten, zelfbeeld, zelfinzicht, zelfvertrouwen en zelfsturend vermogen voor loopbaanadvisering te onderzoeken inzake de mate van sterkte van de onderlinge relaties.

Communicatieve vaardigheden: Uit dit onderzoek is gebleken dat cliënten die minder verbetering ervaren in hun communicatieve vaardigheden als gevolg van de begeleiding, ook minder verbetering zien optreden in hun functioneren. Omdat goede communicatieve vaardigheden ook in het proces van het vinden van een passende werkkring uiterst belangrijk zijn, zou verder onderzoek nuttig zijn voor de vraag op welke wijze deze vaardigheden verder geactiveerd kunnen worden. Beide aspecten, de verbetering van de communicatieve vaardigheden van de cliënt én de verbetering van het functioneren, zouden daar baat bij hebben. Naast verder onderzoek zouden de loopbaanadviseurs zelf de training van hun cliënten inzake de verbetering van communicatieve vaardigheden ter hand dienen te nemen. Dat verbetert meteen het functioneren van de cliënt. Voor zover de adviseurs moeite hebben een dergelijke training te geven, zouden zij zelf ook training dienen te volgen: "train de trainer".

Masteropleiding: Wil loopbaanbegeleiding zich ontwikkelen tot een professie, dan zal het vakgebied een goed ontwikkelde opleiding op wo-niveau dienen te verkrijgen. De auteur van dit proefschrift vindt het een vereiste dat zelfstandig opererende loopbaanadviseurs zowel een masteropleiding als, na een drietal jaren ervaring, een certificaat voor vakbekwaamheid van Career Management Institute (CMI) hebben verkregen om zelfstandig te kunnen opereren.

Ethiek: Zoals in het onderhavige proefschrift is aangetoond, is de kwaliteit van ethisch handelen door loopbaanadviseurs nog onder de maat. De voorbeelden inzake het ethisch dilemma geven dat duidelijk aan. Zelfs de casusvoorbeelden van 
een ethisch dilemma die werden gegeven door adviseurs werkzaam op het breedste CMI-niveau werden maar voor de helft met een 'voldoende' beoordeeld. Dit kan mogelijk deels toegeschreven worden aan het feit dat adviseurs nog onvoldoende ervaring hebben, waardoor zij het ethische dilemma onvoldoende herkennen. Meer en beter onderwijs op dit vlak ligt voor de hand.

Arbeidsmarktbegeleiding: Ook de casusvoorbeelden die adviseurs gaven van arbeidsmarktbegeleiding bleken over het algemeen nog van onvoldoende kwaliteit te zijn. De complexiteit en de grootte van de arbeidsmarkt hebben daar invloed op, alhoewel het inzicht in de arbeidsmarkt door toedoen van de sociale media vereenvoudigd is. De aanbeveling is dan ook om toch tot meer specialisatie te komen. Een specialisatie in de arbeidsmarkt beperkt de kennisfactor voor dat gedeelte van de arbeidsmarkt, waardoor de kwaliteit van de begeleiding aanzienlijk zal stijgen.

\section{Planning en realisatie}

Maatschappelijke erkenning: De realisatie van maatschappelijke erkenning van het vakgebied is noodzakelijk om beschouwd te worden als een professie. Die erkenning voor loopbaanbegeleiding zal dan voor de maatschappij als geheel moeten gelden. Het opvolgen van de aanbevelingen van dit proefschrift zal bijdragen om het vakgebied naar een hoger plan te tillen, waardoor loopbaanadvisering op den duur als professie kan worden erkend. Om dat te bereiken zal dit proefschrift door veel meer onderzoek opgevolgd moeten worden. In dit proefschrift werden vele aanbevelingen voor verder wetenschappelijk onderzoek gedaan als ook aanbevelingen die kunnen bijdragen tot het verbeteren van de praktijk van alle dag. De aanbeveling om niet alleen wetenschappelijk onderzoek te doen naar de korte- en middellange-termijneffecten van loopbaanadvisering, maar 
ook naar de lange-termijneffecten, is voor het vakgebied belangrijk. Dit temeer omdat er momenteel ook veel meer aandacht is voor het belang van de duurzame inzetbaarheid van de werkzame bevolking. Ook is het in dat kader belangrijk om meerdere aspecten van loopbaanadvisering in het onderzoek te betrekken. Dit vergroot de maatschappelijke betekenis van het onderzoek en draagt bij tot verdere maatschappelijke erkenning van het vakgebied.

Kennis assimilatie: Het onderhavige proefschrift wijst op de noodzaak van meer kennis assimilatie als het gaat om de ontwikkeling van het vakgebied in Europa. Zeker in Nederland is er weinig bekend over de ontwikkelingen die zich in de rest van Europa afspelen op het gebied van loopbaanbegeleiding. In dat verband wordt erop gewezen dat stichting NICE daar een betekenisvolle rol in speelt. Een voorbeeld daarvan is de wijze waarop de European Competences Standards for Academic Training of Career Practitioner tot stand kwamen. Via NICE waren er in de periode 2009- 2015 in 30 Europese landen 46 universiteiten die actief meewerkten aan het project om tezamen drie doelen te realiseren: 1) de behoefte aan universitaire training van loopbaanadviseurs op basis van gezamenlijke competenties, waarvoor ook gezamenlijke Europese competentie standaarden zijn gerealiseerd; 2) de behoefte aan interdisciplinair onderzoek op het gebied van loopbaanadvisering en de training van onderzoekers en de bevordering van een internationale onderzoeksgemeenschap in Europa; 3) de behoefte aan het overbruggen van de kloof tussen theorie/onderzoek en praktijk/beleid. Hoe meer onderlinge uitwisseling van kennis er in Europa plaatsvindt, hoe meer het vakgebied zal profiteren van de kennis die op sommige plekken in Europa bestaat, zoals in Engeland, Duitsland, Italië, Polen en Finland. Nederland is hierin achteropgeraakt, maar moet in de toekomst bij de top kunnen behoren. 


\section{Disseminatie}

Gezien de bestaande contacten met de overheid en met name met het Ministerie van Sociale Zaken en Werkgelegenheid, zal de verspreiding van de kennis uit dit proefschrift betrekkelijk eenvoudig te realiseren zijn. De auteur van dit proefschrift zal daarin als adviseur en gewezen voorzitter van het CMI-bestuur ook een rol spelen, door collegae in zowel de branchevereniging als de beroepsvereniging ervan te overtuigen dat het proefschrift relevant is voor de verdere ontwikkeling van het vakgebied als geheel.

Voorts zal het proefschrift in het Engels worden vertaald, waardoor het beschikbaar wordt voor onderzoekers en wetenschappers in loopbaanadvisering, vooral in Europa, maar ook wereldwijd. Bovendien zal de auteur van dit proefschrift zelf een Engelstalig managementboekje samenstellen en publiceren, zodat de innovaties die in het proefschrift worden beschreven in een grotere collegiale kring bekend worden. De auteur van dit proefschrift is voorts bestuurslid van NICE (stichting 'Network for Innovation in Career Guidance \& Counselling in Europe), waarin hij verantwoordelijk is voor het opzetten van de certificering van loopbaanadviseurs in Europa op basis van ISO. Dat geeft een extra mogelijkheid om zowel de wetenschappelijke wereld op het gebied van loopbaanadvisering als de loopbaanadviseurs zelf bekend te maken met de inzichten die uit het proefschrift naar voren komen. 


\section{LITERATUURLIJST}

Abbott, A. (1988). The system of professions: An essay on the division of expert labor. Chicago: University of Chicago Press.

Balint, M. (1954). Analytic training and training analysis. International Journal of Psycho-analyses, 35, 157-182.

Bernaud, J.L., Gaudron, J.P., \& Lemoine, C. (2006). Effects of career counseling on French adults: An experimental study. The Career Development Quarterly, 54(3), 242-255.

Birckmayer, J.D. \& Weiss, C.H. (2000). Theory-based evaluation in practice: What do we learn? Evaluation Review 24(4), 407-431.

Bollens, J. \& Heylen, V. (2010). De macro-economische effecten van het activerend arbeidsmarktbeleid: Een literatuurstudie. Leuven: Katholieke Universiteit.

Briggs, I.M. (2000). Introduction to type: A guide to understanding your results on the MBTI instrument. Oxford: Oxford Psychologists Press.

Burrage, M., Jarausch, K., \& Siegrist, H. (1990). An actor-based framework for the study of professions. In: M. Burrage and R. Thorstendahl (eds.): Professions in theory and history. Rethinking the study of professions. London: Sage.

Byron, K.M. \& Stephen, M. (2002). Loving what is: Four questions that can change your life. New York: Three Rivers Press.

Carr-Saunders, A.M. \& Wilson, P.A. (1933). The professions. Oxford: Clarendon.

CMI (1999; 2003; 2007; 2014). Loopbaanbegeleiding in de praktijk. CMI-uitgaven door Van Dootingh, C.

De Sonnaville, H.K.J.M. (2005). Retorische aspecten van professionaliseren: Een zoektocht naar beroepsvorming bij organisatieadviseurs. Proefschrift, Vrije Universiteit, Amsterdam. 
Donaldson, S.I. (2007). Program theory-driven evaluation science: Strategies and applications. New York, NY: Psychology Press, Taylor \& Francis Group.

Eeden, R. van (2009). Netwerken, zo eenvoudig is het (niet). Houten: Spectrum. Elliott, G.R. (2011). When values and ethics conflict: The counselor's role and responsibility. Alabama Counseling Association Journal, 37(1), 39-45.

Field, A. (2000). Discovering statistics using IBM SPSS, $4^{\text {th }}$ edition, 9200000007682155.

Freidson, E. (1970). Profession of Medicine: A study of the sociology of applied knowledge. New York: Harper and Row.

Freidson, E. (1983). The theory of professions: The state of the art. In R. Dingwall and P. Lewis (eds.): The sociology of professions. London: Macmillan.

Freidson, E. (2001). Professionalism, the third logic: On the practice of knowledge. Chicago: University of Chicago Press.

Glaser, B.G. \& Strauss, A.L. (1967). The discovery of Grounded Theory: Strategies for qualitative research. Hawthorne, NY: Aldine de Gruyter.

Greenwood, E. (1957). Attributes of a Profession. Social Work, 2(3), 45-55.

Haidt, J. (2001). The emotional dog and its rational tail: A social intuitionist approach to moral judgment. Psychological Review, 108(4), 818-834.

Hamaker, G. \& Tielenius Kruythoff, S.P. (2007). De ontwikkeling van loopbaanadvies in Nederland: Loopbaanontwikkeling in de praktijk. CMI-uitgave, vs. 1.

Heppner, M.J. \& Heppner, P.P. (2003). Identifying process variables in career counseling: A research agenda. Journal of Vocational Behavior, 62(3), 429-452.

Hollander, J. \& Wijnberg, J. (2006). Provocatief coachen: De basis. Schiedam: Scriptum.

Holton, J.A. (2008). Grounded Theory as a general research methodology. Grounded Theory Review: An International Journal, 7(2), 67-89. 
Hutjes, J.M. \& Van Buuren, J.A. (1992). De gevalsstudie: Strategie van kwalitatief onderzoek. Heerlen: Open Universiteit.

Johnson, T.J. (1970). Professions and power. London: Routledge.

Kidd, J.M., Jackson, C., \& Hirsh, W. (2003). The outcomes of effective career discussion at work. Journal of Vocational Behavior, 62(1), 119-133.

Kocka, J. (1990). “Bürgertum” and professions in the nineteenth century: Two alternative approaches. In: M. Burrage and R. Thorstendahl (eds.): Professions in theory and history. Rethinking the study of professions. London: Sage.

Kohlberg, L. (1958). The development of modes of moral thinking in the years 10 to 16.

Dissertation, University of Chicago.

Larson, M.S. (1977). The rise of professionalism: A sociological analysis. London: University of California Press.

Likert, R. (1961). New patterns of management. New York: McGraw-Hill.

Maas, J.G.V. (1999). Professionaliteit: Management van professie en professionele organisaties. Deventer: Kluwer.

MacDonald, K.M. (1995). The sociology of professions. London: Sage Publications.

Maister, D.H. (1997). True professionalism: The courage to care about your people, your clients and your career. New York: The Free Press.

Meyer, J.G.K., De Mul, A., Munters, A., \& Van Dijk, K. (2000). Groot coachingsmodellenboek: 50 modellen voor de ontwikkeling van lichaam en geest. Culemborg: Van Duuren Management.

Nillesen, M. (2016). Meetinstrument voor het effect van loopbaanbegeleiding. Heerlen: Open Universiteit Nederland.

Noble, D.F. (1977). America by design: Science, technology and the rise of corporate capitalism. New York: Oxford University Press. 
Ofman, D.D. (1992). Bezieling en kwaliteit in organisaties: Het beroemde boek voor creërende mensen en creërende organisaties. Utrecht: Uitgeverij Servire.

Ofman, D.D. \& De Goede, G. (1992). Kernkwadranten Spel. ISBN 90-90054-1.

Oliver, L.W. (1979). Outcome measurement in career counseling research. Journal of Counseling Psychology, 26(3), 217-226.

Organization for Economic Corporation and Development (OECD). (2002; 2004). OECD Annual Report.

Palmer, S. \& Whybrow, A. (2018). Handbook of coaching psychology: A guide for practitioners. Oxfordshire: Taylor \& Francis.

Parasuraman, A., Zeithaml, V.A., \& Berry, L.L. (1988). Servqual-model: A multipleitem scale for measuring consumer perceptions of service quality. Journal of Retailing, 64(1), 12-40.

Parsons, F. (1954). Choosing a vocation. Boston University: Houghton Mifflin.

Pederson, J. (2004). Project work in the paperless school: A case study in a Swedish upper secondary class. Education and Information Technologies, 9(4), 333-343.

Perdrix, S., Stauffer, S., Masdonati, J., Massoudi, K., \& Rossier, J. (2011). Effectiveness of career counseling: A one-year follow-up. Journal of Vocational Behaviour, 80(2), 565-578.

Piaget, J. (1932). The moral judgment of the child. New York: Simon \& Schuster Inc.

Plant, P. (2004). Quality in career guidance: Issues and Methods. International Journal for Education and Vocational Guidance, 4(1/2), 141-157.

Pol, L. (2011). Voorbeeld van een ethisch dilemma met goede oplossing. CMI-dossier 485. Reichheld, F.F. (2003). The One Number You need to Grow. Harvard Business Review, 81(12), 46-55.

Reynaert, W. \& Spijkerman, R.M.H. (1995). Loopbaandilemma's: Leer- en zoekprocessen op de arbeidsmarkt. LDC Business. 
Schein, E.H. (2002). Entrepeneurial capital: The emerging venture's most important asset and competitive advantage. Journal of Business Venturing, 17(3), 275.

Schiersmann, C., Einarsdóttir, S., Katsarov, J., Lerkkanen, J., Mulvey, R., Pouyaud, J., Pukelis, K., \& Weber, P. (2016). European Competence Standards for Academic Training of Career Practitioners. NICE Handbook, Vol. II. Toronto: Barbara Budrich Publishers.

Schuyt, T.N.M., Louwerse, H., \& Schuyt-Lucassen, N.Y. (1988). Profilering agogische beroepen: Verslag van een verkennend onderzoek in internationale literatuur.

Utrecht: Uitgeverij SWP.

Seegers, J. (2008). Leiders leren: Een idiografisch-nomothetisch onderzoek naar de invloed van persoonlijkheid, leerstijl en leermogelijkheden op de ontwikkeling van leiders aan de top. Proefschrift, Vrije Universiteit, Amsterdam.

Segers, J.H.G. (1999). Methoden voor de maatschappijwetenschappen. Assen: Koninklijke van Gorcum.

Snel, E. (2013). De 'Theory of Change benadering': Weten is meer dan meten. Uit: Omlo, J., Bool, M., \& Rensen, P. Weten wat werkt. Passend evaluatieonderzoek in het sociale domein. Amsterdam: Uitgeverij SWP, 145-164.

Spokane, A.R., Fouad, N.A., Swanson, J.L., \& Walsh, W.B. (2003). Culture-centered career intervention. Journal of Vocational Behavior, 62(3), 459-463.

Stevens, F.C.J. (2014). Sociology of health professions. Hoboken, NJ: John Wiley \& Sons, Ltd.

Strauss, A.L. \& Corbin, J.M. (1998). Basics of qualitative research: Grounded theory procedures for developing grounded theory. ( $2^{\text {nd }}$ ed.). Thousand Oaks, CA: Sage Publications, Inc.

Sultana, R.G. (2002). Guidance policies in the knowledge Society: Trends, challenges and 
responses across Europe. CEDEFOP Report.

Swanborn, P.G. (1996). Case studies: Wat, wanneer en hoe. Amsterdam/Meppel: Boom Lemma Uitgevers.

Tielenius Kruythoff, S.P. (2014). De ontwikkeling van loopbaanadvies in Nederland: Loopbaanontwikkeling in de praktijk. CMI-uitgave, vs. 4.

Tonkens, E. (2008). Marktwerking in de zorg. Uit: F. Ankersmit en L. Klinkers (eds.). De tien plagen van de staat: De bedrijfsmatige overheid gewogen. Amsterdam: Van Gennip.

Van der Horst, A., Hoogstraten, P., Meyer, J.G.K., Serlie, A., \& Wanrooy, M. (2010). Groot psychologisch modellenboek: 51 modellen voor ontplooiing van jezelf en anderen. Culemborg: Van Duuren Management.

Van der Krogt, Th.P.W.M. (1981). Professionalisering en collectieve macht: Een conceptueel kader. 's-Gravenhage: Vuga Uitgeverij.

Vane, S. (2007). Werken met de Roos van Leary: Zicht op communicatieve stijlen binnen social work. Amsterdam: Uitgeverij Nelissen.

Verbruggen, M. (2008). The role of career counseling in the new career era. Proefschrift, Katholieke Universiteit Leuven.

Verbruggen, M. (2010). Career counseling in the new era.0 Review of Business and Economics, 1, 1-21.

Verhulst, J.C.R.M. (2009). RET jezelf: Verstandig omgaan met problemen. Amsterdam: Pearson Assessment en Informatie.

Versnel, H. (2008). Het grote drijfuerenboek: De impact van drijfueren op mensen en organisaties. Amsterdam: Pearson Education.

Vincent, A. (2007). Job Marketing: Het kan! Houten: Unieboek, Spectrum.

Visser, C. (2009). Doen wat werkt: Oplossingsgericht coachen, werken en managen. Culemborg: Van Duuren Management. 
Vogels, E. \& Van Trier, Ch. (2003). Wanneer is actief arbeidsmarktbeleid effectief? Tijdschrift voor Arbeidsmarktvraagstukken, 19(3), 245-256.

Waard, E. de (2002). De veldheer en de danseres. Omgaan met je levensverhaal. Over loopbaanadvies en coaching. Leuven: Garant Uitgeverij.

Watts, A.G. (1999). The economic and social benefits of guidance. Educational and Vocational Guidance Bulletin, 63, 12-19.

Watts, A.G. (2004). Career Guidance Policies in 37 Countries. Joint report OECD, the European Commission and the World Bank.

Weggeman, M. (1997). Kennismanagement: Inrichting en besturing van kennisintensieve organisaties. Schiedam: Scriptum.

Weiss, C.H. (1972). Evaluation research: Methods for assessing program effectiveness. Englewood Cliffs, NJ: Prentice Hall.

Whiston, S.C., Sexton, T.L., \& Lasoff, D.L. (1998). Career-intervention outcome: A replication and extension of Oliver and Spokane. Journal of Counseling Psychology, 45(2), 150-165.

Whiston, S.C. (2002). Application of the principles: Career counseling and interventions. The Counseling Psychologist, 30(2), 218-236.

Whiston, S.C. (2011). Career Counseling: 90 years old yet still healthy and vital. The Career Development Quarterly, 52(1), 35-42.

Whiston, S.C. (2011). Vocational Counseling and Interventions: An Exploration of Future “Big" Questions. Journal of Career Assessment, 19(3), 287-295.

Yperen, T.A. van \& Veerman, J.W. (2008). Zicht op Effectiviteit: Handboek voor praktijkgestuurd effectonderzoek in de jeugdzorg. Delft: Uitgeverij Eburon. 



\section{ENGLISH SUMMARY \\ CAREER GUIDANCE COUNSELLING: AN OCCUPATION ON ITS WAY TO BECOMING A PROFESSION?}

Career guidance counselling, like many other social disciplines, is a unique occupation which may be on its way to becoming a profession. The research in this thesis focusses on the quality of career guidance counselling in the Netherlands. It searches for an answer to the question how far career guidance counselling has come towards becoming a profession. To this end, a broad range of subjects was investigated, resulting in four research chapters. First, in Chapter 4 the quality of ethics in career guidance and especially the ethical dilemmas between the career guidance counsellor, his/her clients and the clients' employers were explored. Second, in Chapter 5 the quality of the specific competences of the career guidance counsellor was researched. Third, in Chapter 6 the quality of the guidance of the client towards the job market by the counsellor was examined. Finally, in Chapter 7 three important effects of career guidance counselling were investigated: clients' job satisfaction, counselling satisfaction and the improvement of work-related skills.

Chapter 1 is an introductory chapter, which is followed by a historical outline of the development of career guidance counselling in the Netherlands over the past 40 years in Chapter 2. In Chapter 3 it was examined to what extent career counselling has developed towards becoming a true profession. For this purpose, a small-scale survey, based on a list of scientific criteria to be met before a discipline can be called a profession, was conducted. Both Greenwood (1957) and Maas (1999) have developed eight criteria for this; Greenwood with the use of the so-called concept approach and Maas with the use of the so-called process approach. 
Subsequently, in order to examine how far career guidance counselling has come towards developing into a profession, it was compared to eight occupational groups that are already considered to be a profession. Experts in these eight occupations, as well as three experts in the field of career guidance counselling, were asked to assess their own discipline based on these criteria. Career counselling received a satisfactory score, but the eight occupations that are called a profession received an even higher score. These results show that career guidance counselling is on its way to becoming a profession, although it needs to be developed further with regard to various points. The two most important criteria that will need to be developed more are public acknowledgment and scientific support. A third important criterion is government legitimation. This criterion is already being applied by the government to some extent: Certification by Career Management Institute (CMI) is being offered to all career guidance counsellors working for the government, herewith guaranteeing their expertise. In doing so, the government itself demonstrates the importance of career guidance.

In Chapter 4 it was investigated to what extent career guidance counsellors are able to handle ethical issues. The importance of ethics and ethical quality for the occupation of career guidance cannot be overstated: without an ethical approach, it would be impossible to practice the occupation. Research was carried out with the use of 170 case studies from existing CMI-files of candidates applying for certification for Registered Career Professional (RC).

Within the framework of certification, CMI requests that candidates give an example of an ethical dilemma that they had encountered while working with a client and how they dealt with this dilemma. For the purpose of this research, these case examples were judged by seven career guidance counselling experts. Using the methods of Kohlberg (1957), each case example was placed in one of five consecutive 
stages of moral development. Results showed that less than half of the 170 career guidance counsellors were able to give a correct example of an ethical dilemma. Further, the research indicates that the extent of correct handling of ethical dilemmas differs between the three CMI-levels ${ }^{1}$. The quality of case examples of ethical dilemmas described by counsellors at broader CMI-levels was better than the quality of those working at a less broad level. It was also found that more years of specific work experience leads to better recognition of an ethical dilemma. Nevertheless, it became clear that career guidance counsellors in general are not as yet sufficiently capable of identifying and handling an ethical dilemma.

In Chapter 5 it was examined to what extent career guidance counsellors had developed five specific competences: empathy, communicative skills, reflection, advising and counselling. For this purpose, twenty career guidance counselling experts assessed 500 case examples from 100 existing CMI-files. It was found that all five of the specific competences were sufficiently to amply developed by the career guidance counsellors in the survey. A difference was found though between the three CMI-levels. First, as expected, career guidance counsellors working at a more extensive level on average scored better at reflection and advising than those working at a less extensive level, although the difference was non-significant. Second, remarkably, career counsellors working at a less extensive CMI-level scored significantly better with regard to two of the five competences - empathy and coaching - than those working at a more extensive level. Finally, it was found that, in general, there were only a few correlations among the five specific competences of career guidance counsellors.

\footnotetext{
${ }^{1}$ Certification of career guidance counsellors by CMI is tested at three levels: level A: client counselling; level B: client counselling plus the contacts with employers; level C: client counselling plus the contacts with employers as well as management advice to organizations (i.e.: from a narrow level to a broader level to an even broader level).
} 
In Chapter 6 the quality of the guidance of the client towards the job market by the career guidance counsellor was examined. Job market counselling is an important part of career guidance counselling. It is the dynamic process of guiding a client from point A to point B. Again, as was done in Chapters 4 and 5, case examples from existing CMI-files were used. First, based on the Grounded Theory developed by Glaser and Strauss (1967), every job market aspect that had been described in the examined 150 case examples was categorized, resulting in nine categories.

Next, seven career counselling experts were asked to place each of the 150 case examples in one of the nine categories. The results showed the three most prevalent categories of job market counselling to be: 1) use of networks and social media in the job market; 2) use of regional and branch knowledge and 3) use of the changes in supply and demand in the job market. Together, these three categories comprise more than half of all the 150 case examples that were examined and categorized. Subsequently, the same experts evaluated the case examples regarding the quality of job market counselling. In general, it was found that career guidance counsellors possess only a marginally satisfactory ability to guide clients to the job market. Furthermore, differences appeared to exist between the three CMI-levels in the quality of job market counselling.

It was found that the counselling of clients towards the job market by career guidance counsellors working at a more extensive CMI-level was of a higher standard than that of counsellors working at a less extensive CMI-level. Further, job market counselling by female career guidance counsellors appeared to be somewhat better than that of male counsellors. Also, job market counselling by career guidance counsellors with an academic degree was somewhat better than that of those with a higher vocational education. However, no relationship was found between the 
specific work experience of career counsellors and the quality of the job market counselling they provide.

Chapter 7 studies the effects of career guidance counselling obtained from three sources: that of the career guidance counsellor himself/herself, that of the client and that of the client's employer. Along with the five aspects of the client's career development process - self-esteem, relationship with the work environment, job functioning, communicative skills and self-regulatory capacity - the research covers the satisfaction of the client about the counselling and above all the satisfaction of the client with his new job. First, it was found that the client's satisfaction with his/her new job (on the average measured three and a half years after the counselling process) was exceptionally high. Further, the satisfaction of the client with the counselling he/she had had was also very high, not only at the start but also three and a half years later. To the author's knowledge, this high and stable result has never been found before. The emotional impact of job loss followed by the emotionally heavy career-counselling process itself could be an important explanation for this finding.

Of the five developmental aspects, the counsellors reported that the selfesteem of their clients had improved the most, followed by the improvement of their clients' self-regulating capacity. The counsellors believed that communicative skills improved the least. The clients themselves perceived counselling to have had a positive influence on all five aspects of the career development process. Like the counsellors, the clients reported that their self-esteem improved considerably with career counselling. The clients also found that their self-regulating capacity as well as their functioning had improved considerably. The employers perceived the functioning of the client to have shown the greatest improvement, followed by the client's relationship with the work environment and the client's communicative 
skills. Moreover, employers were very satisfied with the career guidance counsellors they had chosen. These improvements have a positive effect on the relationship between employer and employee/client.

Conclusion: Although career guidance counselling in the Netherlands does not meet the criteria of a profession yet, the development of the occupation towards a discipline of high quality, which is required to obtain this goal, is potentially present. Various basic issues, such as public recognition, scientific support and legitimation by the government, still need to be resolved. The development of ethical awareness and especially the recognition and handling of ethical dilemmas by career guidance professionals need to be addressed. Furthermore, the quality of job market counselling by career guidance professionals needs further improvement. However, the satisfaction of the clients with their new jobs and the strong relationship between a client's performance and his job satisfaction are probably the most important outcomes of this thesis. After all, a suitable new job and improved functioning in that job are the essence of career guidance counselling. These important issues handled successfully will make the difference between the occupation of career guidance counsellor today and the profession of career guidance counsellor in the future. 


\section{CURRICULUM VITAE}

Peter Tielenius Kruythoff werd geboren op 28 juli 1935 te Bingji (Sumatra 's Oostkust; Indonesië). In de Tweede Wereldoorlog woonde hij met zijn moeder en twee zusjes in Larchmont, USA. Na de hereniging met zijn vader vestigde het gezin zich in Den Haag.

In 1955 behaalde hij zijn HBS-B-diploma aan het 1ste Vrijzinnig Lyceum te Scheveningen, om vervolgens in Militaire Dienst te gaan, waar hij reserve Ritmeester der Huzaren (Regiment Prins Alexander) werd. In 1963 behaalde hij het baccalaureaat examen Economische Wetenschappen en twee jaar later het doctoraalexamen Economische Wetenschappen aan de Gemeente Universiteit te Amsterdam met een scriptie over het 'Basingpoint system', het prijssysteem van de Europese Gemeenschap voor Kolen en Staal (EGKS).

Na zijn opleiding ging hij in het bedrijfsleven werken; aanvankelijk korte tijd bij Philips in Eindhoven, waarna hij medewerker werd van het Macro Economisch Stafbureau van Hoogovens (thans Tatta Steel) te IJmuiden. Als eerste lobbyist vertegenwoordigde hij Hoogovens te Luxemburg en Brussel. Vervolgens werd hij commercieel directeur van respectievelijk de Hollandse Beton groep (HBG; thans B.A.M.) en Overslag Bedrijf Amsterdam (OBA).

In 1984 werd hij partner bij Van Ede \& Partners, waarna hij in 1992 Top Executive Coaching oprichtte als dochterbedrijf van Van Ede \& Partners. Van 1992 tot 2009 was hij lid van het algemeen bestuur van VNO-NCW; van 1991 tot 2000 leidde hij als voorzitter de Nederlandse Organisatie van Bedrijven inzake Outplacement en Loopbaanbegeleiding (NOBOL, thans OVAL), de branchevereniging voor loopbaan-advisering in Nederland; van 1993 tot 2000 was hij tevens voorzitter van Association of Career Firms Europe (AOCF Europa) te Brussel en van 
2001 tot 2003 voorzitter van Association of Career Firms International (AOCFI) wereldwijd met hoofdkantoor te Washington DC.

Van 2003 tot 2007 was hij lid van het bestuur van Institute for Career Certification International (ICCI), de wereldwijde instelling voor certificering van loopbaanadviseurs, en van 2007 tot 2016 leidde Kruythoff als voorzitter de Nederlandse instelling voor certificering van loopbaanadviseurs, het Career Management Institute (CMI), waarna hij gevraagd werd om het instituut als adviseur te blijven bijstaan. In 2017 werd hij lid van het bestuur van de stichting Network for Innovation in Careerguidance \& Counselling (NICE), met de certificering van loopbaanadviseurs in Europa als aandachtsgebied.

Kruythoff is ridder in de orde van Oranje-Nassau, erevoorzitter van de branchevereniging NOBOL en erelid van de beroepsvereniging Noloc. Hij is reeds meer dan 50 jaar getrouwd met Martina van Lidth de Jeude en hij heeft twee volwassen kinderen en zeven kleinkinderen.

Oktober 2018 


\section{Colofon:}

Redactie: Peter Tielenius Kruythoff

Kaft: Annelies le Fèvre - Opdam

Drukkerij: Gildeprint B.V.

ISBN: 978-94-6323-543-3

Alle rechten voorbehouden 


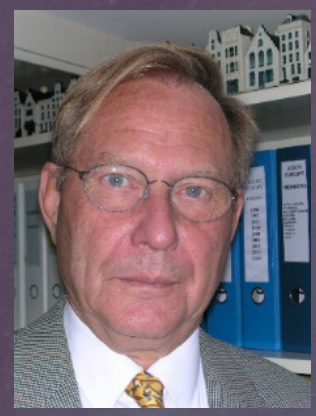

Loopbaanadvisering is een jong vakgebied, dat in de private sector in Nederland nog maar veertig jaar geleden werd gestart toen Paul van Ede in 1978 begon met cliënten naar nieuw passend werk te begeleiden. Indertijd werd het vak outplacement genoemd, thans een onderdeel van het ruimere begrip loopbaanadvisering. Toen Peter Tielenius Kruythoff zich in 1984 bij Van Ede \& Partners voegde, waren er nog maar weinigen die van 'outplacement', laat staan van loopbaanadvisering, gehoord hadden. Zijn vrienden vroegen zich toen ook af of een dergelijke begeleiding wel iets zou toevoegen om mensen beter te laten functioneren, of effectiever te laten communiceren, of de relatie met de werkomgeving te verbeteren. Zij vonden dat mensen in staat moesten zijn om zelfstandig nieuw werk te vinden. Kruythoff was er zelf van overtuigd dat een klankbord belangrijk zou zijn voor een goed resultaat. Sterker nog, hij was ervan overtuigd dat het functioneren van mensen door de begeleiding zeer verbeterd zou kunnen worden. Hij kon deze stelling echter niet bewijzen en zeker niet goed onderbouwd tegenspreken.

Het bovenstaande was onder meer de reden dat Kruythoff aan het einde van zijn carrière besloot om wetenschappelijk onderzoek te doen, om aan te kunnen tonen dat loopbaanadvisering geen 'gebakken lucht' is. En wel degelijk aangetoond kan worden, dat de begeleiding een belangrijke bijdrage levert om cliënten naar een nieuwe passende baan te begeleiden. Het bewijs hiervoor wordt door zijn proefschrift geleverd.

Peter Tielenius Kruythoff werd in 1935 op Sumatra (Indonesië) geboren. In de Tweede Wereldoorlog ging hij in de Verenigde Staten naar school, om na de oorlog naar Nederland te komen voor zijn verdere scholing in Den Haag en voor zijn studie economie aan de UvA te Amsterdam. Na zijn studie ging Kruythoff in het bedrijfsleven werken. Inmiddels werkt hij bijna 35 jaar om loopbaanadvisering op de kaart te zetten. Hij is erebestuurder van de branchevereniging NOBOL en erelid van de beroepsvereniging Noloc. Vanwege zijn verdiensten voor het vak loopbaanadvisering, zowel in Nederland als Internationaal, werd Kruythoff in 2000 benoemd tot Ridder in de Orde van Oranje-Nassau. 